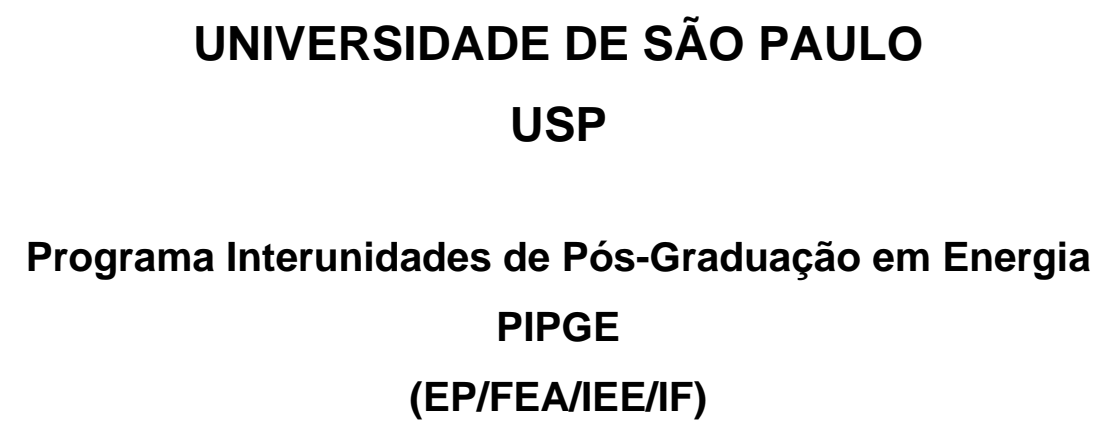

ENERGIA ELÉTRICA E POLÍTICAS PÚBLICAS:

A EXPERIÊNCIA DO SETOR ELÉTRICO BRASILEIRO

NO PERÍODO DE 1934 A 2005

Mônica Landi

São Paulo

2006 
MÔNICA LANDI

\title{
Energia elétrica e políticas públicas: \\ a experiência do setor elétrico brasileiro \\ no período de 1934 a 2005
}

\begin{abstract}
Tese apresentada ao Programa Interunidades de Pós-Graduação em Energia da Universidade de São Paulo (Escola Politécnica / Faculdade de Economia e Administração / Instituto de Eletrotécnica e Energia / Instituto de Física) para obtenção do título grau de doutora em energia.
\end{abstract}

Orientação: Prof. Dr. Célio Bermann

São Paulo 
AUTORIZO A REPRODUÇÃO E DIVULGAÇÃO TOTAL OU PARCIAL DESTE TRABALHO, POR QUALQUER MEIO CONVENCIONAL OU ELETRÔNICO, PARA FINS DE ESTUDO E PESQUISA, DESDE QUE CITADA A FONTE.

FICHA CATALOGRÁFICA

LANDI, Mônica.

Energia elétrica e políticas públicas: a experiência do setor elétrico brasileiro no período de 1934 a 2005 / Mônica Landi; orientador: Dr. Célio Bermann - São Paulo, 2006.

219p. : il.; $30 \mathrm{~cm}$

Tese (Doutorado - Programa Interunidades de Pós-Graduação em Energia) - EP / FEA / IEE / IF da Universidade de São Paulo.

1. Políticas Públicas 2. Setor elétrico - reestruturação 3. Setor elétrico - regulação 4. Setor eletrointensivo I. Título. 
À TITA, AO CAIO E AO FÁBIO PELA SORTE DE TÊ-LOS AO MEU LADO. 


\section{AGRADECIMENTOS}

A finalização do presente trabalho só foi possível graças ao apoio recebido por diversas pessoas que, direta ou indiretamente, contribuíram para que eu pudesse vencer este desafio.

Dentre os professores do IEE, registro um agradecimento especial ao Professor Dr. Ildo Sauer que, ao me convidar para participar do processo seletivo de 2001, possibilitou a minha entrada formal no Instituto, bem como aos Professores Dr. Francisco Anuatti Neto e Dr. Sinclair Guerra que enriqueceram a compreensão do tema escolhido, através de seus esclarecimentos e comentários, durante a fase de qualificação.

Do ponto de vista institucional, deve ser assinalado o apoio recebido da PUC/SP, através da disponibilização da bolsa de capacitação docente/CEPE (Comissão de Ensino de Pesquisa) durante o ano letivo de 2004, bem como pela Fundap (Fundação do Desenvolvimento Administrativo) e Secretaria de Estado de Economia e Planejamento, em particular no período de conclusão desse trabalho. Ressalte-se, contudo, que nessas instituições, eu tive a sorte de ter podido contar com o constante estímulo de duas grandes amigas, Margret Althuon e Mirna Ayres Issa Gonçalves, cuja cumplicidade eu receio nunca conseguir retribuir.

Registro, ainda, um carinho especial a todos os familiares e amigos que acompanharam a evolução da presente tese e que, assim como eu, nos últimos tempos, torceram para a sua conclusão. Como a lista é enorme, não explicitarei nomes, como de costume, para não magoar ninguém por uma eventual omissão, mas tenham certeza de que a todos deixo consignada a minha eterna gratidão. À minha mãe, entretanto, faltam palavras para agradecer o carinho e a dedicação dispensados aos meus filhos, durante meus longos períodos de ausência, que espero poder compensar daqui para frente.

Ao Fábio, companheiro de todas as horas, ao Caio e à Tita, meus queridos filhos, só me resta agradecer pela paciência que tiveram comigo, em particular nos últimos meses, e dividir com vocês a sensação de dever cumprido. Muito obrigada.

Por fim, gostaria de registrar meu profundo agradecimento ao meu orientador, Professor Dr. Célio Bermann, por seu estímulo e eterna disposição em ajudar para a conclusão do meu projeto. Os erros e omissões, contudo, como de praxe, são de inteira responsabilidade da autora. 


\section{RESUMO}

LANDI, M. Energia elétrica e políticas públicas: a experiência do setor elétrico brasileiro no período de 1934 a 2005. 2006. 194 p. Tese de doutorado. Programa Interunidades de Pós-Graduação em Energia. Universidade de São Paulo.

O presente trabalho foca-se na análise do processo de reestruturação do setor elétrico brasileiro, em particular nas mudanças ocorridas do ponto de vista institucional e regulatório, entre os anos de 1995 a 2004. Tendo como pano de fundo esse cenário, a tese preocupa-se em analisar a evolução do papel do Estado e sua relação com as políticas públicas orientadas para esse segmento da infra-estrutura nacional. Analisa-se, de um lado, a passagem do padrão de intervenção estatal para o modelo mercantil privado, instituído a partir de 1995, e de outro, as diversas adaptações vivenciadas pelo setor ao longo do biênio 2003/2004. Neste particular, destaca-se o novo papel atribuído às agências reguladoras e ao Estado, bem como a nova política mercantil, de preços e de planejamento redefinida para o setor. Por fim, à luz de toda a discussão abordada sobre Estado, políticas públicas e setoriais, planejamento e modelo regulatório, caracteriza-se a política industrial brasileira, divulgada em novembro de 2003, e sua possível articulação tanto com as premissas levantadas no modelo de reestruturação do setor elétrico brasileiro em curso no País, quanto com a revisão da inserção do Brasil no cenário internacional, dado o peso que os produtos ligados a empresas eletrointensivas, vêm ganhando na pauta de exportação brasileira. Neste particular, são analisadas as estratégias adotadas por tais empresas na tentativa de reduzir o custo do insumo energia, em seus processos produtivos, no âmbito das regras vigentes no país, em especial, no Ambiente de Contratação Livre (ACL). Conclui-se que a articulação entre política industrial e setor elétrico só será possível, se for definida com clareza uma nova estratégia de desenvolvimento sustentável para o Brasil, capaz de superar os limites impostos pela política macroeconômica de curto prazo. 


\begin{abstract}
LANDI, M. Electricity and public policies: the experience of the Brazilian electrical sector, 1934 to 2005. 2006. 210 f. Doctoral Thesis. Inter-departmental Graduate Program in Energy. Universidade de São Paulo.
\end{abstract}

This study analyzes the restructuring of the Brazilian electrical sector, in particular the institutional and regulatory changes between 1995 and 2005. With this context as a backdrop, the dissertation analyzes the evolution of the role of the State and its relation with public policies related to this sector of national infrastructure. It analyzes, the shift from the pattern of state intervention to free market model, implemented starting in 1995, as well as the various adaptations the sector underwent in 2003-2004. In this regard, attention is given to the new role attributed to regulatory agencies and to the State, as well as the new commercial, price and planning policies implemented for the sector. Finally, in light of the discussion of the State, public and sectoral policies, planning and regulatory model, a description is provided of the Brazilian industrial policy announced in November of 2003, and its possible connection with the premises revealed in the model of restructuring of the electrical sector under way in Brazil, as well as the rethinking of the role of Brazil in the international context, given the weight that electricity-intensive products have been gaining in terms of exports. In this regard, the strategies of such companies to reduce energy costs in their production process, in the context of Brazilian rules and regulations, and in particular, the Free Contracting Environment (ACL), are analyzed. It is concluded that coordination of industrial policy and the electrical sector will only be possible if there is a clearly defined sustainable development strategy for Brazil, able to overcome the limitations of short-term macroeconomic policies. 


\section{SUMÁRIO}

INTRODUÇÃO

CAPÍTULO 1: ESTADO, REGULAÇÃO ECONÔMICA E POLÍTICAS PÚBLICAS: a evolução da abordagem econômica para o setor elétrico

1.1 - Mercado ou intervenção estatal

1.2 - Regulação econômica e serviços públicos

1.2.1 - Regulação econômica e as agências reguladoras 35

1.2.2 - Mecanismos de regulação: a questão do regime tarifário 37

$\begin{array}{ll}\text { 1.2.2.1. Tarifação pela taxa de retorno } & 38\end{array}$

1.2.2.2. Tarifação pelo custo marginal 38

1.2.2.3. Price Cap 39

1.2.2.4. Regulação por desempenho (yardstick competition ou benchmark) 40

$\begin{array}{ll}\text { 1.2.2.5. Tarifa pelo preço } & 40\end{array}$

1.3 - Regulação econômica e políticas públicas $\quad 40$

CAPÍTULO 2: O ESTADO E O DESENVOLVIMENTO DO SETOR ELÉTRICO BRASILEIRO: as políticas públicas durante o período de 1934 à 1989

2.1 - Introdução

2.2 - A formação do setor elétrico brasileiro: do nacionalismo implacável do Presidente Getúlio Vargas à criação da Eletrobrás

2.3 - O desenvolvimento do setor de energia elétrica e as reformas do período 1964/79

2.4 - A crise dos anos 80 e os efeitos das políticas de ajustamento para o setor elétrico nacional

\section{CAPÍTULO 3: A REESTRUTURAÇÃO DO SETOR ELÉTRICO} BRASILEIRO: a adoção de um novo modelo institucional durante os anos 90 e a revisão no biênio 2003-2004

3.1 - Um cenário em mutação: a ênfase liberal da política econômica dos anos 90

3.2 - A reestruturação do setor elétrico e sua regulamentação básica: da Lei ${ }^{\circ} .8 .631 / 93$ à Lei no $9.648 / 98$

3.3 - Os (des)ajustes da reestruturação do setor elétrico: de 1998 até 2002

3.3.1 - As tentativas de correção: as propostas do Relatório Kelman e da Câmara de Gestão da Crise de Energia Elétrica

3.3.2 - As principais medidas implementadas durante o racionamento e a Lei ${ }^{\circ} 10.438 / 2002$

3.4 - O "novíssimo" modelo institucional do setor elétrico brasileiro: a revisão ocorrida entre 2003/2004 e os resultados dos leilões de energia existente, realizados em 2004 e 2005 
3.5 - A proposta de mudança na legislação relativa às agências reguladoras:

o Projeto de Lei $n^{\circ} 3.337 / 2004$

CAPÍTULO 4: SETOR ELÉTRICO E POLÍTICA INDUSTRIAL: uma estratégia de articulação para o Brasil

4.1 - Introdução

4.2 - O enfoque dado ao tema "Política Industrial e de Comércio Exterior", durante o período compreendido entre 1990-2002, e seus efeitos

na pauta de exportação brasileira

4.3 - A Política Industrial, Tecnológica e de Comércio Exterior - PITCE, divulgada em novembro de 2003

4.4 - A PITCE e o Setor Elétrico Brasileiro: uma resposta do setor eletrointensivo

4.4.1 - O setor eletrointensivo e a opção pela autoprodução de energia elétrica

4.4.2 - O setor eletrointensivo e o Ambiente de Contratação Livre (ACL)

4.4.2.1 - Participação no leilão de compra de excedente de energia elétrica

4.4.2.2 - Ambiente de contratação livre e os leilões de compra de energia para uso próprio

CONSIDERAÇÕES FINAIS

REFERÊNCIAS BIBLIOGRÁFICAS

ANEXO: AS EXPERIÊNCIAS INSTITUCIONAIS E REGULATÓRIAS DE PAÍSES SELECIONADOS: os casos inglês, norueguês e argentino 


\section{LISTA DE TABELAS}

Tabela 1.1. - Taxas médias anuais de crescimento de economias capitalistas avançadas (1960/1978)

Tabela 1.2. - Taxas médias anuais de crescimento de economias em desenvolvimento $(1960 / 1985)$

Tabela 2.1. - Mudanças na estrutura de importações brasileiras, em percentagens anuais médias (1901-1929)

Tabela 2.2. - A estrutura industrial brasileira em 1919 e 1939 (distribuição percentual do valor agregado total)

Tabela 2.3. - Grupo Light: consumo de energia elétrica, para anos selecionados

Tabela 2.4. - Evolução de indicadores econômicos selecionados (1925-1945)

Tabela 2.5. - Principais rubricas do balanço de pagamentos brasileiro (1937-1947), em US\$ milhões

Tabela 2.6. - Comissão Mista Brasil - Estados Unidos - Programa de Energia Elétrica (1952-1957)

Tabela 2.7. - Plano de Metas - previsão de acréscimo de potência instalada de energia elétrica, por grupos de obras (1957-1965)

Tabela 2.8. - A evolução da capacidade instalada de energia elétrica, por categoria de concessionário (1952-1961)

Tabela 2.9. - Participação do BNDE na expansão da capacidade instalada de energia elétrica (1954-1962)

Tabela 2.10. - Tarifas de energia elétrica (1963-1973)

Tabela 2.11. - Arrecadação do IUEE e do empréstimo compulsório (1961-1970)

Tabela 2.12. - Participação (\%) das fontes de recursos do setor de energia elétrica $(1967 / 1973)$

Tabela 2.13. - Setor elétrico: evolução da capacidade instalada e do consumo de energia elétrica (1963-1973) 
Tabela 2.14. - Energia Elétrica: Inversões, em Cr\$ Milhões (1969 - 1973)

Tabela 2.15. - Taxa de inflação, evolução do PIB e balança comercial (valores FOB)

Tabela 2.16. - Energia elétrica: inversões - Cr\$ Milhões (1974-1980)

Tabela 2.17. - Estrutura dos ingressos brutos anuais, segundo a propriedade do capital por tomador, com destaque para participação do setor de energia (1972-1980) em \%

Tabela 2.18 - Fontes de recursos do setor de energia elétrica (1974-1984) em \%

Tabela 2.19. - Setor elétrico: evolução da capacidade instalada e do consumo de energia elétrica (1973-1979)

Tabela 2.20. - Tarifa de fornecimento, taxa de remuneração média, IUEE, EC, CRC e RGR (1980-1991)

Tabela 2.21. - Perfil do endividamento do setor elétrico, por moeda e prazo em US\$ milhões, a preços constantes de 1989

Tabela 2.22. - Indicadores selecionados par o período 1980-1991

Tarifa 3.1. - Preços médios de energia elétrica nas gestões Collor e Itamar Franco, em R \$ dez/95

Tabela 3.2. - Principais resultados do balanço de pagamentos do Brasil (1984-1998)

Tabela 3.3. - Preços médios de energia elétrica para 1995-1998, média mensal de R\$ julho/98

Tabela 3.4. - Resultados dos leilões de privatização do setor elétrico (1995-2000)

Tabela 3.5. - Abrangência das agências estaduais conveniadas

Tabela 3.6. - Valores previstos e repassados, 1998-2002

Tabela 3.7. - Preços Médios de energia para 1999-2002

Tabela 3.8. - Valores previstos e repassados, 2003-2005 
Tabela 4.1. - Previsão de consumo de energia elétrica (MWh) dos setores industriais eletrointensivos

Tabela 4.2. - Capacidade instalada de geração elétrica de autoprodutores em MW, em 31/12/2004

Tabela 4.3. - Principais compradores do leilão de excedente de energia elétrica, vinculados ao setores eletrointensivos.

Tabela 4.4. - Principais compradores do leilão de excedente de energia elétrica por setores

Tabela 4.5. - Vendedores do leilão de excedente de energia elétrica

Tabela 4.6. - Distribuição do total ofertado, por submercado de entrega 


\section{LISTA DE QUADROS}

Quadro 1.1. - Modelos estruturais propostos para o setor

Quadro 2.1. - Prioridades de Governo

Quadro 3.1. - Sumário dos principais problemas apontados no Relatório Kelmann e os temas que deveriam ser investigados

Quadro 3.2. - Síntese dos Relatórios de Progresso do Comitê de Revitalização do Setor Elétrico

Quadro 3.3. - Principais Agentes e suas Funções

Quadro 3.4. - Resultados dos leilões de energia existente, realizados em 2004 e 2005

Quadro 4.1. - Sumário do PITCE Balanço 2005

Quadro 4.2. - Usinas licitadas pela ANEEL para autoprodução (AP)/Produção Independente (PI) de propriedade de setores industriais eletrointensivos: 1995 - 2002

Quadro 4.3. - Outras usinas hidrelétricas licitadas para autoprodução (AP)/Produção Independente (PI) de propriedade de setores industriais eletrointensivos, com anuência da ANEEL: 1995 - 2002

Quadro 4.4. - Situação das usinas fiscalizadas pela ANEEL - julho/2006 


\section{LISTA DE FIGURAS}

Figura 3.1. - Agências reguladoras criadas no Brasil e os convênios firmados com a ANEEL

Figura 3.2. - Convivência do Mercado Regulado e do Mercado Competitivo

Figura 3.3. - Mecanismos licitatórios 


\section{INTRODUÇÃO}

O presente trabalho procura relacionar a evolução do setor elétrico brasileiro com a orientação predominante de políticas públicas no período compreendido entre 1934 e 2005 , de maneira a demonstrar que existe, de fato, forte associação entre a política estabelecida para esse importante segmento da infra-estrutura nacional e o encaminhamento dado aos demais instrumentos de política econômica definidos para o País. Dessa forma, o objetivo central do trabalho é o de mostrar como se processa essa articulação e seus efeitos sobre o modelo institucional e econômico-financeiro organizado para o setor ao longo desses anos.

O texto preocupa-se, também, em avançar no sentido de sinalizar uma possível correlação entre a política energética em curso e a política industrial divulgada em novembro de 2003, pela equipe do Ministério do Desenvolvimento, da Indústria e do Comércio Exterior, uma vez que só será possível uma transição sintonizada em direção a uma trajetória de desenvolvimento, caso sejam intensificados os estudos voltados à junção de diversas políticas ativas de governo. Neste particular, sugere-se a ampliação da discussão, ainda tímida, sobre o papel das fontes de energia renováveis, em especial os biocombustíveis, onde o Brasil poderia se transformar em um grande exportador não apenas do produto em si, mas também, de capacidade tecnológica, abrindo espaço para a revisão da estratégia, por exemplo, de outras cadeias de exportações, tais como a de setores eletrointensivos. Na ausência, entretanto, de tal revisão, o estudo aponta as saídas encontradas pelas empresas vinculadas a esse segmento da industrial nacional, no ambiente regulatório definido para o setor elétrico, tendo em vista a posição assumida por tais commodities na pauta de exportações brasileiras, em especial ao final dos anos 90 .

A motivação para a escolha do tema, por outro lado, centra-se na evidente importância que o insumo energia assume no processo de desenvolvimento dos países. No caso brasileiro, pode-se constatar que, desde o início do processo de industrialização, os gargalos diagnosticados para a área são sempre entendidos como fortes barreiras ao crescimento da economia nacional, levando à formulação, em distintas oportunidades, de políticas específicas, com o propósito de superar tais limites.

Partindo-se dessa percepção, identificam-se dois momentos particulares de orientação no encaminhamento dessas políticas. Na primeira fase, compreendida entre 1934 
a 1989, prevalece a forte atuação do Estado, tanto na consolidação de desenho institucional e econômico-financeiro para o setor, em especial entre os anos de 1964, com a criação da Eletrobrás, até 1979, quando o setor viveu seu grande período de expansão, quanto como agente responsável e indutor dos investimentos na área. A segunda fase, por sua vez, iniciase em 1990, quando há a passagem de um padrão de intervenção estatal para um modelo mercantil privado, apesar das adaptações vivenciadas pelo setor ao longo do biênio 2003/2004.

Essa periodização, entretanto, revela, também, estreita relação com os princípios e fundamentos econômicos dominantes no contexto internacional, em cada uma das etapas demarcadas, tornando de extrema valia entender de que forma ocorre esta relação para o caso brasileiro e seu impacto para o setor elétrico nacional.

Isto porque, na primeira fase, dado o entendimento predominante à época de que se a economia fosse abandonada à lógica do mercado correria um sério risco de funcionar em crise, a intervenção direta do Estado, preconizada pelos fundamentos da teoria keynesiana, prevalece na maioria dos países centrais e em desenvolvimento. Assim, o amplo consenso acerca das limitações do mercado permitiu a adoção de uma orientação de política econômica centrada na presença do Estado na atividade econômica interna, em uma política fiscal garantidora da execução de políticas de renda e de administração da demanda agregada, e nas despesas públicas, como principal motor de uma fase continuada de expansão econômica, com destaque inclusive para a atuação das empresas estatais, viabilizando, dentro desse paradigma, o desenvolvimento do setor elétrico brasileiro.

Tal comportamento, entretanto, a partir da década de 80 , dá sinais de forte descompasso, em particular dado o esgotamento do padrão de financiamento anterior que, para os países da América Latina, acaba intensificando o endividamento externo e rolagem da dívida interna. Nesse ambiente, ganha destaque o retorno às práticas de políticas econômicas mais ortodoxas, centradas em um enfoque monetário restritivo e na austeridade fiscal, através de expressivos cortes nos gastos públicos correntes, incluindo seus investimentos produtivos. Reforma tributária, da previdência e do próprio Estado é estimulada de maneira a contribuir para a redução do déficit público, neutralizando, assim, seu efeito sobre a demanda global e o processo inflacionário.

Em paralelo, assumem papel de destaque, de um lado, os programas de privatização, 
dado o elevado estoque de ativos produtivos estatais transacionáveis, capazes de minimizar o estoque da dívida pública, e de outro, a revisão dos próprios modelos institucionais, regulatórios e econômico-financeiros organizados para os principais setores da infraestrutura nacional, sob os argumentos da perda de eficiência produtiva e a busca pela ampliação do atendimento com maior qualidade e menores tarifas ${ }^{1}$.

Ressalte-se, entretanto, que essa ênfase fiscal, na articulação da privatização às demais medidas de política econômica, priorizando a transferência de seus ativos públicos para a iniciativa privada, acaba se sobrepondo a uma racionalidade setorial. Abandona-se, assim, a opção de aliar a privatização a uma política mais ampla de reestruturação industrial, que exigiria a revisão prévia do aparato institucional/regulatório, a partir de um novo entendimento do papel do Estado e de sua inserção na economia nacional.

Dessa forma, é neste contexto que se inicia o segundo período de evolução do setor elétrico brasileiro, cujo processo de reestruturação vivenciado, particularmente, entre 1995 e 2002, vai ao encontro da nova ordem econômica que, ao defender a competitividade e a globalização das economias, coloca o Estado na posição de agente regulador de modos mais efetivos e eficientes de produção de bens e serviços, até então sob as mãos de monopólios públicos, dentro dos mecanismos e da dinâmica do mercado.

Nessa linha, identificam-se os segmentos de mercado potencialmente competitivos, desverticalizando o modelo integrado anterior que, para o caso do setor elétrico, passa pelo reordenamento das áreas de negócios em produção de energia (geração), transporte nas tensões mais altas (transmissão), transporte com o específico objetivo de atendimento a consumidores finais (distribuição) e vendas no varejo, com a função de medir e faturar os consumidores finais (comercialização). Com isso, o setor passa a ser visto como um "negócio", capaz de permitir a entrada de recursos no curto prazo, contribuindo para o ajuste fiscal e do balanço de pagamentos, sob a justificativa da "falência" do poder de financiamento do Estado.

\footnotetext{
${ }^{1}$ Assim, o Estado abandona suas funções empresariais, responsáveis em grande parte pelo desenvolvimento industrial desses países, acreditando que as desestatizações, articuladas às demais medidas voltadas para a diminuição das necessidades de financiamento do setor público, venham a garantir a entrada de recursos no curto prazo, com a pretensão de se reduzir a demanda futura por gastos fiscais, liberando, assim, recursos para a área social. Dessa forma, o elevado estoque de ativos produtivos estatais transacionáveis possibilitaria a troca patrimonial de um crescente e rígido estoque de dívida pública.
} 
Completando tal orientação e como forma de contornar eventuais falhas de mercado, entendidas como assimetria de informação, externalidade negativa, comportamento colusivo ou não otimizante dos agentes, indivisibilidades e outras violações das hipóteses neoclássicas para o equilíbrio geral competitivo, tenta-se montar um novo sistema institucional relacionado à regulação econômica dos serviços públicos, com a introdução de um novo regime tarifário e formas contratuais efetivas, capazes de repassar para o mercado a arbitragem da maior parte dos riscos assumidos pelos agentes econômicos.

A partir desse entendimento, a metodologia empregada neste trabalho recorreu a diversos autores que, ao longo dos últimos anos, preocuparam-se em caracterizar a evolução do setor elétrico brasileiro, com ênfase em seus aspectos institucionais, padrão de financiamento, incluindo a questão tarifária, bem como as mudanças setoriais ocorridas ao longo do período em questão, com a inclusão de textos que contribuíram para identificar as principais medidas de política econômica utilizadas como pano de fundo na análise do contexto estudado.

Particularmente, no que se refere à discussão sobre a defesa de uma política industrial para o País, foi de grande valia o texto de Erber (2002), que conseguiu, em meio a vozes discordantes, introduzir o debate sobre o tema, ao colocar que o Estado deva se manter como agente estruturante nas novas forças produtivas, através de ações específicas, voltadas para a introdução de inovações tecnológicas e o aprimoramento das capacitações locais, tanto em empresas como em cadeias produtivas. A partir desta visão, foi possível alinhavar uma relação entre a política industrial brasileira e o modelo do setor elétrico brasileiro, reforçando o pressuposto de que o projeto de desenvolvimento nacional deva ser marcado, por exemplo, pela busca da sustentabilidade energética ${ }^{2}$ e pela preocupação de reavaliar a importância que o insumo "energia" pode assumir para a sociedade ${ }^{3}$.

\footnotetext{
${ }^{2}$ A noção de sustentabilidade energética pode ser entendida como sendo a busca pela incorporação de fontes renováveis de energia (biomassa, eólica, solar, etc...) no processo de produção, respeitando o meio ambiente, de forma a assegurar às gerações futuras os recursos naturais e energéticos, ainda disponíveis, e criar um novo conceito de sociedade, revendo a lógica do consumo e desperdício presentes na sociedade capitalista. Essa noção de sustentabilidade energética foi amplamente explicitada em Bermann (2002), capítulo 1.

${ }^{3}$ Sabe-se que a energia representa tanto um insumo básico, no processo produtivo, quanto um determinante do padrão de qualidade de vida da sociedade, por ser um bem público. Dessa forma, é tarefa do Estado, seja através da definição de suas políticas setoriais e/ou mecanismos de regulação, auxiliar na busca do acesso a esse serviço, minimizando o processo de exclusão social, bem como, na identificação de tarifas diferenciadas,
} 
Foi pesquisada, ainda, a legislação que cobre o setor, com destaque para as alterações verificadas do ponto de vista institucional e regulatório, além das informações constantes na ANEEL (Agência Nacional de Energia Elétrica) e na CCEE (Câmara de Comércio de Energia Elétrica), de maneira a contribuir para a elaboração de quadros específicos utilizados ao longo do texto. O trabalho recorreu, também, a consultas e páginas eletrônicas especializadas, com o propósito de identificar diferentes posicionamentos afetos aos agentes e grupos de interesse envolvidos com o setor, com particular atenção sobre a ABRACE (Associação Brasileira de Grandes Consumidores Industriais de Energia e de Consumidores Livres).

Assim, o presente trabalho será distribuído em quatro capítulos, além desta introdução e das considerações finais. O primeiro capítulo tem a preocupação central de analisar a evolução do papel do Estado e sua relação com as políticas públicas orientadas para o setor elétrico, a partir de suas principais características, lembrando que, como bem coloca Guimarães (2000, p.20), as políticas setoriais deveriam ser capazes de atender aos seguintes objetivos prioritários: a) o aumento de produtividade; b) a redução de custos; c) a melhoria da qualidade dos produtos; e d) o repasse desses ganhos ao consumidor.

Nessa abordagem, a ênfase será discutir, com base nos principais fundamentos predominantes ao longo do período estudado, em que contexto dá-se a passagem do padrão de intervenção estatal para o modelo mercantil privado e as mudanças regulatórias atreladas a esse movimento, com destaque para os mecanismos de regime tarifário. Na seqüência, é feita uma breve associação entre os princípios que norteiam a regulação econômica e sua possível articulação com outras ações públicas, particularmente com a condução de uma política industrial para o país.

O segundo capítulo destaca a evolução do setor elétrico brasileiro, resgatando desde a criação do Código de Águas, em 1934, até a fase de endividamento externo e a crise dos anos 80 , que culminou com a implantação de diversas políticas de ajustamento para o setor.

$\mathrm{Na}$ verdade, a distribuição do capítulo tenta ser fiel às diversas fases por que passaram o setor, mapeando as principais medidas adotadas durante o nacionalismo do Presidente Getúlio Vargas, a importância que a criação da Eletrobrás assumiu para o setor,

para garantir a competitividade de setores produtivos selecionados. Essa preocupação foi explicitada em Bermann (2002, p. 18). 
com ênfase nas reformas conduzidas no período entre os anos de 1964 a 1979, e as modificações relacionadas à estrutura de financiamento do setor, no qual a participação dos recursos próprios acaba, progressivamente, sendo substituída pela de origem externa, levando a constrangimentos não superados na década seguinte.

Isto porque, ao final do ciclo de crescimento ficam evidentes os limites da atuação do Estado no setor elétrico brasileiro, explicados, de um lado, pela sua subordinação aos interesses da política macroeconômica, nem sempre sintonizada aos objetivos setoriais, e de outro, dadas às contradições internas do próprio modelo institucional e econômicofinanceiro organizado para o setor, que acabou se revelando inadequado, em razão da intensificação dos conflitos federativos.

Dessa forma, o terceiro capítulo buscará levantar o modelo de reestruturação desenhado para o setor elétrico brasileiro, ao longo da década de 90, cujo processo teve início em 1993, quando regras de seu funcionamento passaram por modificações importantes e várias propostas de remodelação institucional e financeira do setor começaram a ser discutidas ${ }^{4}$.

Na seqüência, é exposto o modelo final para o setor apresentado, em 1997, durante a gestão do Presidente Fernando Henrique Cardoso, a partir da proposta formulada pelo Consórcio liderado pela empresa Coopers \& Lybrand, contratado pelo Ministério das Minas e Energia e pela Eletrobrás, para a execução do estudo. Centrando sua análise na elaboração de um modelo regulatório/institucional, bem como um modelo mercantil e de financiamento para o setor elétrico brasileiro, a proposta buscou atingir dois objetivos básicos, quais sejam: a) manter, a princípio, as funções política e de regulamentação nas mãos do Governo e; b) transferir, ao setor privado, a responsabilidade sobre operação e investimento, anteriormente a cargo do setor público. Com isso, o Estado, de um lado, concentraria suas ações na formulação de políticas para o setor, delineando, inclusive, a base de atuação do agente regulador e, de outro, transferiria a responsabilidade sobre a operação e investimento ao setor privado e de benefícios aos usuários, decorrentes do novo arranjo mercantil.

\footnotetext{
${ }^{4}$ Dentre tais medidas merecem destaque: a) Lei 8.631/93, que eliminou o regime tarifário pelo custo do serviço; e b) Decreto 1.009/93, que criou o SINTREL, sugerindo a desverticalização contábil das concessionárias, ambas analisadas no Capítulo 3.
} 
A partir da descrição do modelo e da regulamentação básica a ele vinculada, em particular no que se refere às mudanças institucionais/regulatórias e ao modelo mercantil, o capítulo tenta identificar alguns limites dessa opção, que aos poucos foi se mostrando inadequada para o setor elétrico brasileiro. A crise de racionamento de energia, vivenciada ao longo de 2001, também mapeada no terceiro capítulo, acaba por reforçar os limites dessa reforma, tornando-se alvo de inúmeros questionamentos. Nesse cenário, sobressai a fragilidade do aparato regulatório/institucional, bem como a ausência de uma clara política energética capaz de responder aos objetivos centrais da reforma, mergulhando o setor em um ambiente de incertezas, resultado tanto da forma prematura com que foi encaminhada sua desverticalização e privatização, quanto da falta de regras claras de atuação dos diversos agentes envolvidos. Conforme explicita Sauer (2002, p. 2), “a renúncia, pelo Estado, de seu papel de planejador e orientador de políticas em um setor de vital importância para o desenvolvimento social e econômico do país", acaba por acentuar os limites impostos pela reforma.

Completando o capítulo, são apresentadas as tentativas de correção, propostas no âmbito do Relatório Kelmann e pela Câmara de Gestão da Crise de Energia Elétrica, além das diversas adaptações vivenciadas pelo setor elétrico brasileiro, ao longo do biênio 2003/2004, sob administração do Presidente Luís Inácio Lula da Silva, particularmente no que se refere ao novo papel das agências reguladoras e do Estado, com destaque para a atuação do Ministério das Minas e Energia, bem como à nova política mercantil, de tarifas e de planejamento redefinida para essa área da infra-estrutura nacional.

Por fim, o quarto capítulo visa, inicialmente, mapear, à luz de toda a discussão levantada sobre Estado, políticas públicas e setoriais, planejamento e modelo regulatório, a política industrial, divulgada em novembro de 2003, e a sua possível articulação tanto com as premissas levantadas no "novíssimo" modelo de reestruturação do setor elétrico brasileiro $^{5}$, quanto com a revisão da inserção do Brasil no cenário internacional, tendo em

\footnotetext{
5 Registre-se que o termo "novíssimo" aqui utilizado, conforme será explicitado no capítulo terceiro, visa apenas diferenciar a revisão implementada, em especial durante os dois primeiros anos da gestão do Presidente Luís Inácio Lula da Silva e ainda em curso no país, com a reestruturação conduzida ao longo da década de 90, por entender que ambas retratam tentativas muito recentes de rearticular o setor elétrico brasileiro, não buscando, portanto, revelar nenhum tipo de conotação pejorativa ao termo.
} 
vista que nos últimos anos, vêm ganhando espaço, na pauta de exportação brasileira, os produtos ligados a empresas eletrointensivas, que possuem baixo valor agregado.

Na seqüência, serão analisadas, ainda, as estratégias adotadas por tais empresas na tentativa de reduzir o custo do insumo energia, em seus processos produtivos, no âmbito das regras vigentes no país, em especial, na participação em empreendimentos de usinas hidrelétricas de energia, como autoprodutores e/ou produtores independentes, no Ambiente de Contratação Livre (ACL). 


\section{CAPÍTULO 1: ESTADO, REGULAÇÃO ECONÔMICA E POLÍTICAS PÚBLICAS: a evolução da abordagem econômica para o setor elétrico}

\subsection{Mercado ou intervenção estatal}

O período pós-guerra foi marcado por uma elevada e sistemática ampliação e intervenção estatal na economia, fundamentada na crítica teórica de Keynes ${ }^{6}$ às doutrinas associadas à defesa do capitalismo laissez-faire, ainda presentes em fins do século XIX e início do século XX, cujos principais elementos ideológicos, sintetizados por Hunt (1982, p. 426), eram:

“(1) a teoria da distribuição baseada na produtividade marginal, que retratava o capitalismo concorrencial como um ideal de justiça distributiva; (2) o argumento da "mão invisível", que retratava o capitalismo como um ideal de racionalidade e eficiência; e (3) a fé na natureza automática e auto-regulável do mercado, que demonstrava que as principais funções do Governo deveriam ser fazer cumprir os contratos e defender os poderes e privilégios da propriedade privada".

Tais elementos assegurariam os argumentos em favor dos mercados auto-ajustáveis, expressos, particularmente, na Lei de $\mathrm{Say}^{7}$, em que "toda oferta cria sua própria demanda", limitando-se, assim, as funções do governo da época, regido pelo rigor orçamentário do Estado Mínimo, ou seja, poucas despesas poucos impostos. Infelizmente, depressões, cada vez mais freqüentes, minaram essa base teórica, levando à sua revisão.

É nesse ambiente, que é legitimada a intervenção econômica direta do Estado, defendida por Keynes, em dois vetores básicos de atuação: i) na expansão e generalização dos mecanismos de garantia de renda, expressa no sistema de transferência, bem como na ampla expansão da prestação de serviços sociais, principalmente educação, saúde e infraestrutura urbana; e ii) no envolvimento crescente do Estado, direto e indireto, na produção de bens e serviços.

\footnotetext{
${ }^{6}$ John Maynard Keynes (1883-1946), em sua obra intitulada A Teoria Geral do Emprego, dos Juros e da Moeda, publicada em 1936, procura mostrar o que teria acontecido com o modo de produção capitalista, particularmente no período entre a primeira guerra mundial e a grande depressão de 1929. Ao demonstrar que as premissas relativas ao mercado auto-ajustável tinham perdido sua utilidade ideológica, passa a defender uma nova orientação de política econômica, onde a intervenção estatal torna-se fundamental instrumento na luta para preservar o sistema.

${ }^{7}$ Jean-Baptiste Say (1767-1832) foi autor da obra Um Tratado de Economia Política, cuja finalidade central era demonstrar que o resultado natural de uma economia capitalista era a harmonia social e não o conflito de classes. Considerava-se discípulo de Adam Smith, autor de A Riqueza das Nações.
} 
Como expressa Brunhoff (1991), para Keynes o importante é induzir um processo de colocação da mão-de-obra, de distribuição das rendas e de absorção dos produtos, defendendo, não apenas o financiamento público de obras que criem empregos, mas também, investimentos privados.

$\mathrm{Na}$ verdade, abandonada à lógica do mercado, Keynes acreditava que a economia correria o risco de funcionar em crise. Por esse motivo, defendia a intervenção econômica direta do Estado sobre o volume de investimentos, de maneira a induzir a criação de empregos, compensando, assim, a eventual insuficiência das empresas privadas.

Dessa forma, o envolvimento do Estado, como bem sintetiza Prado (1994, p. 12), esteve relacionado a motivações referentes à criação, utilização e sustentação de parcelas do sistema produtivo, em quatro pontos centrais, a saber: 1) implantação de setores econômicos estratégicos em economias com baixa disponibilidade de capital; 2) interesse em controlar/interferir na composição e no volume de demanda agregada e setorial; 3) garantia de oferta de insumos básicos e estratégicos; e 4) sustentação de indústrias e/ou empresas em dificuldades econômicas e financeiras, seja por se tratar de setores estratégicos, seja por envolver políticas regionais e/ou de emprego.

Essa intervenção estatal, como bem coloca Brunhoff (1991, p. 22), assumiu o nome de política econômica, ao representar um conjunto de medidas discricionárias que afetavam a economia nacional através do orçamento (política financeira), da política monetária (ação sobre o crédito e a taxa de câmbio), da política social (regulamentação dos salários, instalação de regimes de seguro), da política comercial (concessão de subsídios) e da política industrial (adoção de incentivos fiscais e creditícios em setores selecionados).

Em outras palavras, o amplo consenso acerca das limitações do mercado permitiu a adoção de uma orientação de política econômica centrada, principalmente, na presença do Estado na atividade econômica nacional, em uma política fiscal garantidora da execução de políticas de renda e de administração da demanda agregada, e nas despesas públicas, mesmo que em gastos militares, como principal motor de uma fase continuada de expansão econômica.

Essa tendência é reforçada, ainda mais, dado o forte dinamismo apresentado, especialmente pelo grande capital monopolista norte americano, que introduz sua estrutura 
industrial e seus padrões de consumo, através de uma nova articulação da economia mundial. Conforme colocam Coutinho e Belluzzo (1998, p. 23):

"Essa articulação se processou em vários planos. Pelo seu peso e características, a economia americana assegura uma dinamização generalizada de todo o conjunto das economias avançadas, abrindo brechas, em seu mercado interno, notadamente para a penetração de produtos alemães e japoneses, cujos setores exportadores eram fundamentais para a manutenção de seus respectivos ritmos de crescimento".

Além disso, as empresas americanas, ao se instalarem no Mercado Comum Europeu, levam os grandes capitais europeus a se fortalecerem, com o objetivo de, também, consolidarem suas posições nesse mercado.

Evidentemente que esse movimento, de internacionalização do capital monopolista, acaba avançando para os países periféricos, que estão iniciando seus processos de industrialização, muitos desses também com uma forte presença do Estado, dada a fragilidade do capital privado doméstico. Assim, os países em desenvolvimento passam a se "beneficiar" da entrada desses investimentos externos, representando um dos principais elementos que viabilizou esse rápido processo de acumulação ${ }^{8}$.

Como resultado, por quase trinta anos, as principais economias capitalistas conseguiram manter os níveis adequados de demanda efetiva, em decorrência da crescente atuação estatal, tendo os gastos públicos como principal fator anticíclico do período, mesmo que determinadas ações exigissem a presença do Estado apenas por um período de tempo específico e limitado.

A partir de meados da década de 70, contudo, esse receituário keynesiano dá mostras de que é incapaz de impedir a crise. A economia mundial mergulha em uma etapa descendente de um longo ciclo de crescimento, marcada pela desaceleração dos investimentos, em parte explicada por Coutinho (1998, p.50), como sendo resposta à “exaustão da etapa acelerada de internacionalização das grandes empresas", especialmente dos oligopólios internacionais, que acabou por gerar uma crise global de superacumulação industrial após 1974, levando à crescente ampliação da capacidade ociosa existente 9 .

\footnotetext{
${ }^{8}$ Oliveira, F. (1984) em seu livro A Economia da Dependência Imperfeita faz uma brilhante abordagem da articulação existente entre padrões de acumulação, oligopólios e Estado, para o caso brasileiro.

${ }^{9}$ Coutinho (1998), em seu artigo intitulado "Percalços e problemas da economia mundial capitalista. Estado,
} 
A Tabela 1.1. retrata as quedas percentuais no patamar de crescimento econômico vivenciadas pelas principais economias capitalistas avançadas, durante o período compreendido entre 1960 e 1978.

Tabela 1.1

Taxas médias anuais de crescimento das economias capitalistas avançadas para o período 1960/1978

\begin{tabular}{|c|c|c|c|}
\hline Países & $\begin{array}{c}\text { Média 1960/73 } \\
\mathbf{( \% )}\end{array}$ & $\begin{array}{c}\text { Média 1974/78 } \\
\mathbf{( \% )}\end{array}$ & $\begin{array}{c}\text { Queda do patamar de } \\
\text { crescimento } \\
\text { (\%) }\end{array}$ \\
\hline Estados Unidos & 3,9 & 2,2 & -44 \\
\hline Japão & 10,5 & 3,7 & -65 \\
\hline Alemanha & 4,9 & 1,7 & -65 \\
\hline França & 5,7 & 2,8 & -51 \\
\hline Inglaterra & 3,2 & 1,0 & -69 \\
\hline Canadá & 5,0 & 3,4 & -32 \\
\hline Itália & 5,2 & 1,9 & -63 \\
\hline
\end{tabular}

Fonte: OCDE, extraído de Coutinho (1998, p. 46).

Ademais, conforme argumenta Coutinho (1998, p. 50), a própria quadruplicação do preço do petróleo, nesse momento, comprometeu ainda mais as taxas de acumulação, levando a uma forte reação inflacionária e colocando a crise energética em destaque, ao revelar outro aspecto da crise estrutural do padrão tecnológico dominante desde o início do século XX, isto é, "a massificação do consumo de bens duráveis (automóveis, eletrodomésticos etc.) que superimpôs um determinado padrão de uso de recursos energéticos e matérias-primas, com um fluxo de demanda crescente..., e disparos nos preços relativos".

Nesse ambiente, caracterizado pela "estagnação", isto é, alta de preços com recessão, logo, desemprego, era de se esperar que as bases da política econômica keynesiana fossem questionadas, ressuscitando os velhos princípios liberais "abandonados" em meados do século XX, marcados pelo discurso: Estado intervencionista ou mercado regulador; gastos públicos e desperdícios ou iniciativa privada eficiente.

Assim, a crise de superacumulação, decorrente do processo de acumulação do

estagnação e riscos financeiros", detalha as diferentes variáveis que interferiram no enfraquecimento do dinamismo da economia mundial capitalista durante essa fase. 
capital das principais economias avançadas, além de revelar uma crise social ao rebaixar o valor real dos salários, em razão das pressões inflacionárias aceleradas, transforma-se, também, em uma crise do próprio Estado, ao evidenciar os limites de sua atuação.

Este cenário, conforme se verifica na Tabela 1.2., impacta nos países da América Latina, um pouco mais tarde, porém de forma mais perversa, uma vez que os governos perderam "o controle de seus orçamentos, enquanto políticas monetárias flexíveis haviam conduzido a uma inflação galopante", como assinala Stiglitz (2002, p.43).

Tabela 1.2

Taxas médias anuais de crescimento de economias em desenvolvimento, selecionadas para o período $1960 / 1983$, em $\%$

\begin{tabular}{|c|c|c|c|c|c|}
\hline Países & $\begin{array}{c}\text { Média } \\
\mathbf{1 9 6 1 / 7 3} \\
\text { (A) }\end{array}$ & $\begin{array}{c}\text { Média } \\
\mathbf{1 9 7 4 / 7 8} \\
\text { (B) }\end{array}$ & $\begin{array}{c}\text { Média } \\
\mathbf{1 9 7 9 / 8 5} \\
\text { (C) }\end{array}$ & $\begin{array}{c}\text { Queda do } \\
\text { patamar de } \\
\text { crescimento } \\
\text { (B/A) }\end{array}$ & $\begin{array}{c}\text { Queda do } \\
\text { patamar de } \\
\text { crescimento } \\
\text { (C/A) }\end{array}$ \\
\hline Argentina & 3,9 & 1,2 & 0,3 & -69 & -92 \\
\hline Brasil & 7,6 & 6,4 & 3,1 & -16 & -59 \\
\hline México & 6,7 & 5,7 & 4,1 & -15 & -39 \\
\hline
\end{tabular}

Fonte: Corecon/SP, extraído do Banco Mundial. Elaboração própria.

Dessa forma, a partir de meados dos anos 80 , é enfatizado o retorno às práticas de políticas econômicas mais ortodoxas, centradas em um enfoque monetário restritivo e na austeridade fiscal, através de expressivos cortes nos gastos públicos correntes, incluindo seus investimentos produtivos. Reforma tributária, da previdência e do próprio Estado é estimulada de maneira a contribuir para a redução do déficit público, neutralizando, assim, seu efeito sobre a demanda global e o processo inflacionário ${ }^{10}$.

Completando esse conjunto de medidas, programas de privatização são conduzidos e/ou a reestruturação de várias indústrias são defendidas, na busca de uma adaptação, conforme destaca Pontes (1999), à nova era de competitividade e globalização das

\footnotetext{
${ }^{10}$ Esse conjunto de medidas pode ser sintetizado no que, em novembro de 1989, passou a ser denominado "Consenso de Washington", representando uma corrente de pensamento, centrada na defesa de regras técnicas em favor da economia de mercado, que visavam, em tese, a recuperação econômica dos países latinoamericanos, formulada a partir de um texto do economista John Williamson, do International Institute for Economy. As dez regras que sintetizam o "Consenso de Washington" são: disciplina fiscal, redução dos gastos públicos, reforma tributária, juros de mercado, câmbio de mercado, abertura comercial, investimento estrangeiro direto, com eliminação das restrições, privatização das estatais, desregulamentação (afrouxamento das leis econômicas e trabalhistas) e direito de propriedade.
} 
economias, na qual o desafio centra-se em encontrar modos mais efetivos e eficientes de produzir bens e serviços, até então sob as mãos de monopólios públicos, dentro dos mecanismos e da dinâmica do mercado.

$\mathrm{Na}$ verdade, como aponta Araújo (1997), a onda de inovações tecnológicas, centrada, basicamente, nos avanços experimentados nos segmentos da microinformática e das telecomunicações, contribui para reforçar a tese de que muitos dos serviços de utilidade pública poderiam ser radicalmente reestruturados, desde que mantidas reguladas as partes, que permanecessem monopólios naturais, e retirado o controle do Estado, das demais, tendo em vista sua incapacidade em responder, prontamente e de forma eficiente, às mudanças em curso.

Baseada na teoria dos mercados contestáveis $^{11}$, a ascensão do pensamento neoliberal, defendido inclusive pelas principais instituições globais, particularmente, Fundo Monetário Internacional (FMI) e Banco Mundial (BIRD), passa a questionar a presença da intervenção estatal, em qualquer setor da atividade econômica. A lógica que prevalece é: menos Estado, mais mercado.

Entretanto, como forma de contornar eventuais falhas de mercado ${ }^{12}$, a montagem ou o desenvolvimento de um sistema institucional eficiente relacionado à regulação econômica dos serviços públicos, torna-se necessário. Acredita-se que a flexibilização operacional e a fragmentação das empresas prestadoras de serviços públicos, com a introdução de um número maior de operadores em cada sistema/segmento, em associação com a montagem de mecanismos operacionais de regulação, sejam suficientes para atrair mais facilmente o capital privado, aumentar a concorrência e satisfazer as demandas específicas destes serviços públicos, por consumidores e cidadãos, de modo mais eficiente e barato que se possa obter em condições de mercado.

No caso específico do setor elétrico, o movimento de reforma de sua organização

\footnotetext{
${ }^{11}$ A teoria dos mercados contestáveis, que tem em Baumol (1982) um dos seus principais teóricos, defende que, em determinadas condições, tais como a ausência de barreiras à entrada e à saída, um monopólio poderá ter comportamento aproximadamente competitivo, em decorrência da simples ameaça de entrada de novas firmas.

${ }^{12}$ Como ressalta Araújo (1997), a justificativa clássica para a regulação econômica é a existência de falhas de mercado, podendo ser entendida como: assimetria de informação, externalidade negativa, comportamento colusivo ou não otimizante dos agentes, indivisibilidades, e outras violações das hipóteses neoclássicas para o equilíbrio geral competitivo.
} 
industrial, iniciado ao final da década de 80, mantém essa mesma lógica, ao estabelecer como principal objetivo a introdução da concorrência na geração de eletricidade e na prestação de serviços elétricos. Para atender a essa finalidade, passou a prevalecer a seguinte orientação:

“i) os capitais privados substituam o Estado na gestão da indústria de suprimento de energia; ii) as empresas elétricas sejam desverticalizadas para viabilizar a concorrência no suprimento de seus serviços; iii) o órgão regulador passe a atuar como interface entre o governo e os agentes do mercado elétrico e, também, como responsável pela arbitragem de eventuais conflitos de interesses entre esses agentes; iv) seja introduzido um novo regime tarifário, orientado para a busca da eficiência econômica; e v) seja estruturado um regime contratual, que repasse para o mercado a arbitragem da maior parte dos riscos assumidos pelos agentes econômicos" (IPEA, 1997, p. 9).

Evidentemente, que o grau de adoção destes princípios tem variado de país para país e dependido, em muito, da matriz energética, da parceria público-privada pretendida para o setor à luz de uma nova estrutura de mercado, da formatação do regime regulatório, além, é claro, da própria importância que esse movimento de reestruturação setorial assume para o ajuste das contas internas e/ou para a ampliação da capacidade de oferta de energia elétrica do país. De qualquer modo, a maioria dos modelos de reestruturação tem buscado minimizar a atuação do Estado, criando estruturas que induzam os atores à eficiência econômica, a partir da competição no setor, com a transferência para o mercado da responsabilidade pela sua expansão, conforme caracterizado no Quadro 1.1., que sintetiza a descrição de cada modelo estrutural passível de ser utilizado.

Quadro 1.1.

Modelos estruturais propostos para o setor

\begin{tabular}{|l|c|c|c|c|}
\hline \multicolumn{1}{|c|}{ Características } & Modelo 1 & Modelo 2 & Modelo 3 & Modelo 4 \\
\hline Definição & $\begin{array}{c}\text { Monopólio em } \\
\text { todos os níveis }\end{array}$ & $\begin{array}{c}\text { Competição na } \\
\text { geração e } \\
\text { comprador } \\
\text { único }\end{array}$ & $\begin{array}{c}\text { Competição na } \\
\text { geração e } \\
\text { escolha para } \\
\text { distribuidoras }\end{array}$ & $\begin{array}{c}\text { Competição na } \\
\text { geração e } \\
\text { escolha para o } \\
\text { consumidor } \\
\text { final }\end{array}$ \\
\hline Competição na geração & Não & Sim & Sim & Sim \\
\hline Escolha para varejistas & Não & Não & Sim & Sim \\
\hline Escolha para consumidor final & Não & Não & Não & Sim \\
\hline
\end{tabular}

Fonte: Hunt e Shuttleworth (1996) 
Em outras palavras, o chamado "Consenso de Washington", como sinaliza Canuto (2000), ao se fixar em torno das bandeiras da privatização, desregulamentação e liberalização comercial, acabou dando pouca atenção às instituições e à complementaridade entre as esferas pública e privada na economia, tendo em vista que o automatismo de mercado também produz distorções. Assim, entendendo que tanto os mercados como o Estado podem falhar, defende que o sucesso econômico depende do reforço mútuo e do aprimoramento simultâneo de tais instituições.

Neste ambiente, a revisão do modelo do setor elétrico e sua inclusão no modelo de desenvolvimento não devem mais se limitar à simples assunção dos países "emergentes" ao processo de globalização e ao seu receituário de estabilidade monetária, austeridade fiscal e liberdade comercial/financeira, conforme preconiza a maioria das autoridades econômicas locais. Passa, sim, pela adequação da força do Estado e do escopo de suas funções, conforme propõe Fukuyama (2004), visando construir um Estado capaz de definir políticas públicas ativas, que, de um lado, não eternizem privilégios nem mascarem ineficiências setoriais, e, de outro, minimizem "a lógica imediata dos mercados de cristalizar situações de baixo crescimento ou forte desigualdade social", Canuto (2000).

Dessa forma, duas questões parecem ganhar relevância na busca deste equilíbrio, que prevê um processo de reaparelhamento do Estado, em seus aspectos legais, institucionais, administrativos e mesmo operacionais, adequados às particularidades de cada país. A primeira refere-se à caracterização da própria evolução da regulação econômica como um importante elemento integrador desse movimento ao assumir "responsabilidades bastante especializadas e específicas, delimitadas em suas leis de constituição, com relação à orientação, coordenação, regulamentação e fiscalização de aspectos das políticas e dos procedimentos gerais de cada setor", como bem colocam os autores Cintra e Bonini (1997, p. 7). E a segunda centra-se na própria atuação do Estado, com o intuito de definir políticas de caráter estratégico para o desenvolvimento da economia nacional e, particularmente, para o setor elétrico.

Dentro desta preocupação, os próximos itens tentarão mapear a evolução da regulação econômica focada no setor elétrico, objeto da presente tese, para, na seqüência, discutir a sua articulação com uma estratégia de política industrial voltada para esse setor. 


\title{
1.2. Regulação econômica e serviços públicos
}

Evidentemente que a regulação das atividades econômicas não é uma prática que surge, somente ao final do século XX, acompanhando os processos de privatização. Conforme lembra Araújo (1997, p.1),

"Desde as antigas civilizações de Babilônia, Egito e China até os dias de hoje, parte significativa das normas e leis de cada sociedade visa ordenar a atividade econômica de modo a garantir a prosperidade geral. Na verdade, não existe mercado funcionando sem alguma base de leis, normas e convenções sociais, que lhe dão sua forma específica e até seu conteúdo".

O sentido moderno, contudo, que ganha destaque, refere-se a órgãos e regulamentos existentes para controlar a estrutura e o funcionamento de serviços públicos, em especial, transportes, energia elétrica, gás, comunicações, água e saneamento básico. Segundo o autor,

\begin{abstract}
"Estes setores têm em comum, no todo ou em parte, algumas características importantes: seus produtos são considerados básicos para a vida econômica e social, nas sociedades modernas; apresentam significativas externalidades em seu funcionamento, ou seja, as transações afetam terceiros e a própria coletividade; dentro do próprio setor podem existir economias de escala e escopo ('monopólios naturais), bem como complementaridades que favoreçam a coordenação sobre a competição; tendem a necessitar investimentos importantes, com longos prazos de maturação e esses investimentos são específicos ao setor, com irreversibilidade (custos irrecuperáveis)".
\end{abstract}

Assim, essas características implicam a necessidade de algum tipo de intervenção pública, com o objetivo de garantir que tais serviços públicos sejam prestados, mesmo que pela iniciativa privada, de forma aceitável, do ponto de vista econômico e social. Com o avanço dos processos de privatização, até mesmo os países sem tradição nesse tipo de conduta, passam a incluir em seus modelos institucionais, agências regulatórias, capazes de atender a essas exigências, para cada um dos diferentes setores.

Nesta linha, a missão regulatória, com base nas considerações levantadas por Pires e Piccinini (1999), centra-se em:

a) atingir a eficiência econômica, garantindo o serviço ao menor custo para o 
usuário $^{13}$;

b) impedir o abuso do poder de monopólio, assegurando a menor diferença entre preços e custos, de forma compatível com os níveis desejados de qualidade do serviço;

c) garantir o serviço universal, como direito de cidadania, e a qualidade do serviço prestado;

d) propiciar o estabelecimento de canais para atender a reclamações dos usuários ou consumidores sobre a prestação dos serviços, de forma a impedir discriminações injustas entre consumidores;

e) estimular a inovação (identificando oportunidades de novos serviços, removendo obstáculos e promovendo políticas de incentivo à inovação);

f) buscar a padronização tecnológica e a compatibilidade entre equipamentos; e

g) preservar a segurança e a proteção ao meio ambiente, fiscalizando as externalidades.

Em suma, do exposto parece ficar claro que a regulação teria como objetivo central garantir o bem estar da sociedade podendo ser, como ressaltam os autores, até mesmo, compreendida como uma resposta política do aparelho de governo às pressões de grupos de interesse de consumidores e empresas, com objetivos conflitantes entre si ou com terceiros.

\footnotetext{
${ }^{13} \mathrm{Na}$ verdade, como bem destacado por Possas, Ponde e Fagundes (1997, p.86), o objetivo central da regulação de atividades econômicas não é promover a concorrência como um fim em si mesmo, mas aumentar o nível de eficiência econômica dos mercados correspondentes. Os autores lembram, ainda, que são utilizados na análise econômica basicamente quatro conceitos de eficiência: produtiva, distributiva, alocativa e dinâmica. O primeiro consiste na utilização, com máximo rendimento e mínimo custo, da planta produtiva instalada e respectiva tecnologia. O segundo refere-se à capacidade de eliminação, por meio da concorrência ou de outro dispositivo, de rendas monopolísticas ou outros ganhos temporários por parte dos agentes individuais. O terceiro, de eficiência alocativa, é o mais controvertido tendo se tornado praticamente sinônimo de eficiência econômica. Isto porque, na visão das aplicações normativas da análise econômica, em particular a de origem paretiana, os chamados teoremas de bem estar mostram que só os mercados sob concorrência perfeita, em equilíbrio geral, permitem alcançar o ótimo de Pareto, ao igualar o preço do produto ao seu custo marginal. Dessa forma, as ações regulatórias estariam buscando, através de sua atuação, alcançar a condição paretiana, nas situações em este ambiente de concorrência perfeita não se verifica. Finalmente, a eficiência dinâmica é um conceito que considera o mercado como ambiente seletivo, ou seja, com a capacidade de selecionar inovações de produto e de processo que resultem em redução futura de custos e de preços e em melhoria da qualidade dos produtos.
} 
Dessa maneira, as agências regulatórias surgiriam pela demanda de grupos sociais, como uma instituição extra-mercado par resolver conflitos econômicos, necessária para proteger tanto os usuários quanto os investidores.

Nesses termos, embora certas adaptações, na reorganização ou na montagem do modelo regulatório, sejam realizadas, na busca de torná-lo mais adequado à estrutura setorial, jurídica e institucional existentes, entre os diversos países, alguns pontos centrais parecem nortear a implantação das agências regulatórias. Dentre eles destacam-se ${ }^{14}$, por exemplo:

a) a independência das agências tanto em relação ao governo quanto no que diz respeito aos demais agentes do setor. Esse aspecto é fundamental para que o regulador possa cumprir sua missão pública de defesa do bem estar dos consumidores e tenha autoridade suficiente para fazer a arbitragem de conflitos entre acionistas, consumidores, empresas e governo. Essa independência é função, inclusive, da autonomia de seus recursos financeiros, o que só poderá ser possível caso suas receitas sejam compostas por recursos orçamentários próprios, provenientes, em geral, da outorga de concessões e de taxas cobradas pela fiscalização das atividades das firmas reguladas;

b) a diretoria deve ser estável para viabilizar sua independência decisória, assim como bem definidas, por mecanismos estatutários e regras estabelecidas pelo Poder Executivo e Legislativo, as funções e atribuições das agências. Com isso, poderão ser reduzidos os riscos dos investidores em relação a possíveis atos discricionários do poder concedente e ampliados a capacidade de fiscalização da sociedade;

c) a agência deve ser suficientemente especializada para reduzir, ao máximo, as assimetrias de informação e os riscos de captura, dando legitimidade à ação regulatória, uma vez que muitas vezes deverá ser exercido o poder de arbitragem; e

d) existência de cooperação entre os diferentes órgãos reguladores, setoriais ou não, no sentido de adoção de procedimentos, abordagens e ritos processuais similares, em especial no que diz respeito à defesa da concorrência e do consumidor. Desta forma, deve ser garantido o acesso às informações necessárias para as adequadas

\footnotetext{
${ }^{14}$ Essas características foram extraídas de Pires e Piccinini (1999).
} 
investigações sobre os casos de comportamento anticompetitivo e de neglicência na qualidade do serviço prestado.

Completando os princípios básicos relacionados à ação regulatória, cumpre destacar, ainda, que são identificados, a partir da bibliografia pesquisada, dois padrões de regulação. A regulação dos serviços públicos de infra-estrutura (utilities) e a regulação de mercados em geral, destinada à prevenção e repressão de condutas anticompetitivas (antitruste).

A primeira, denominada por Possas, Ponde e Fagundes (1997, p.87-88) como regulação ativa, "constitui uma intervenção voltada não a induzir maior concorrência, mas a substituí-la por instrumentos e metas administrados publicamente, em atividades econômicas caracterizadas por "falhas de mercados"”. Assim, através da atuação permanente e de caráter interventivo, poderiam ser controlados, particularmente, os preços adotados por essas empresas, bem como a qualidade dos serviços prestados.

No outro lado, tem-se a regulação reativa, que, de acordo com os autores, através do monitoramento ad hoc, não sistemático, seria acionada somente por iniciativa de interesses privados ou difusos ameaçados, "envolvendo condutas anticompetitivas previstas em lei, ou pela ocorrência de 'atos de concentração' (fusões e aquisições), também previstos em lei, de forma a evitar o aumento substancial do poder de mercado das empresas envolvidas, e com isso, o risco de futuras condutas prejudiciais à concorrência”.

Para efeito da presente tese, a análise cobrirá apenas a regulação ativa, uma vez que sua preocupação é avaliar a atuação das agências regulatórias e, portanto, suas práticas preventivas, particularmente nos segmentos de energia elétrica mantidos em regime de monopólios, bem como sua capacidade de acompanhar e fiscalizar o desempenho dos agentes envolvidos, de forma a intervir em situações de conflitos e inibir práticas abusivas de poder.

Com esta preocupação, a seguir serão caracterizados alguns aspectos relacionados à prática regulatória, com destaque para os principais mecanismos de controle utilizados em segmentos monopolistas, em especial no que se refere aos regimes tarifários, visando atingir, a partir do acompanhamento dos custos, dos lucros e da alocação de recursos 
resultados de remuneração dos serviços públicos de energia elétrica, muito semelhante a ambientes mais competitivos, atendendo, assim, sua principal missão regulatória.

\subsubsection{Regulação econômica e as agências reguladoras}

Do exposto, parece ficar claro que a regulação ativa pode ser compreendida,

"como um conjunto de leis e controles que se originam do governo e afetam o funcionamento do mercados, interferindo, deste modo, na eficiência interna e alocativa de empresas e de indústrias" (Santana e Oliveira, 1999, p. 59).

Dessa forma, a preocupação primária do sistema regulatório é criar mecanismos de incentivo, capazes de influenciar as ações dos agentes envolvidos, minimizando as falhas na operação dos mercados, expressas em termos de externalidades ${ }^{15}$, de poder e de assimetrias de informações. Nesta linha, a ação regulatória costuma se concentrar em três pontos, isto é, qualidade, preços e condições de entrada e saída, de maneira a buscar padrões de qualidade dos serviços oferecidos, a garantir a eficiência produtiva e a impedir a discriminação entre os consumidores, visando o bem-estar da sociedade.

Evidentemente, como ressaltam Santana e Oliveira (1999, p. 60), essa não é uma tarefa fácil, uma vez que cabe, de um lado, ao regulador induzir a firma a tomar decisões de preços, produção e investimentos que respondam aos interesses da sociedade, nas condições acima destacadas, e de outro, a firma maximizar seus lucros ou receitas.

Como neste movimento há uma nítida divergência de objetivos, é de suma importância consolidar um desenho institucional, no qual os reguladores possam atuar de forma independente, a partir de mandatos bem definidos e expressiva capacitação técnicooperacional, tornando-os impermeáveis às ações de captura. Isto porque, há uma forte tendência à captura do órgão regulador, em decorrência de problemas de disponibilidade e acesso a informações ${ }^{16}$, onde esse passa a confundir o interesse comum com os interesses da própria indústria que é por ele regulada, ou, da mesma forma, a subordinar suas decisões

\footnotetext{
${ }^{15}$ Isto é, quando o bem-estar de um agente econômico (empresas ou consumidores) é diretamente afetado pelas ações de terceiros.

${ }^{16}$ Dentre os vários tipos de assimetrias de informações, Salgado (2003, p.15/16) destaca dois em especial: a) permitir que a agência estabeleça compromissos com grupos de interesses (compartilhar rendas) às expensas dos consumidores; e b) dificuldade da agência de avaliar custos e benefícios esperados, tendo em vista a falta de transparência das empresas reguladas e do acesso às reais informações.
} 
a outros interesses do governo, inclusive sua instrumentalização.

Dentre as formas de inibir essa conduta, Salgado (2003, p. 16) sinaliza que, além da autonomia financeira e administrativa da agência, do mandato fixo e de exigências de qualificação técnica, e não indicação política, para o exercício de postos de decisão, podese exigir da agência reguladora, por exemplo, prestação de contas, de maneira a afinar suas decisões com os objetivos previstos em lei.

Além disso, a transparência das decisões das agências pode ser ainda maior se existir o prévio conhecimento das regras que orientam suas análises, "a publicação de manuais e guias, assim como de todos os procedimentos adotados pelo órgão, reduz as incertezas do público interessado e funciona como disciplinador de tendências à "captura" por interesses velados", Salgado (2003, p. 16).

Outro ponto que merece destaque é o consenso de que quanto mais imperfeito for o mercado maior será a necessidade de se introduzir práticas regulatórias, uma vez que o pior cenário é o do monopólio não regulamentado. Isto porque, conforme destacam Santana e Gomes (1999, p. 80),

"quando não existem incentivos para reduzir custos, torna-se possível, dado o poder de mercado do monopólio, repassá-los para o consumidor, utilizando-se de uma estratégia de elevação de preços que lhe aumentaria as margens de lucro".

Assim, para estes casos, a tarefa do regulador é controlar a distribuição e quantidade do excedente social, garantindo à concessionária um lucro razoável, mas inibindo o abuso do poder de mercado. Da mesma forma, a intervenção estatal na prestação de serviços públicos deve-se limitar aos níveis indispensáveis à sua execução, permitindo que a agência reguladora tenha condições de liberdade de atuação.

Por fim, deve-se registrar, ainda, que a regulação também pode influenciar a dinâmica tecnológica de uma indústria/setor ao introduzir incentivos de investimentos em pesquisa e desenvolvimento, estimulando à inovação tecnológica, a partir, por exemplo, da introdução de metas e padrões internacionais de qualidade a serem perseguidos.

Em suma, esse conjunto de questões, de um lado, tenta sistematizar os diversos pontos que permeiam a discussão relativa à concepção de um ambiente favorável à prática 
da missão regulatória, capaz de agir de forma isenta aos interesses particulares e ao mesmo tempo reduzir os riscos regulatórios e atrair investimentos. E de outro, revela a dificuldade de se introduzir tais mudanças, em especial em sociedades onde as práticas de representatividade não estejam tão disseminadas tanto na esfera pública como na própria sociedade, ao limitar o número de canais de pressão. Além disso, a definição clara do papel das agências reguladoras, incluindo neste caso a separação de suas funções entre a esfera federal e estadual, depende do desenho institucional e organizacional pretendido para o setor, que neste particular necessita precisar sua estratégia de inserção no cenário nacional, leia-se sua articulação com as demais políticas públicas.

$\mathrm{Na}$ ausência de tal clareza, a simples criação de agências reguladoras com a introdução de mecanismos de controle e de políticas tarifárias em um ambiente híbrido, no qual os agentes privados e públicos atuantes no setor não saibam, de fato, suas funções, pode revelar um desenho institucional ineficaz e impróprio ao atendimento da própria razão da criação de tais agências, ou seja, minimizar as falhas de mercado.

Apesar de tais ponderações, o próximo item tenta registrar as principais práticas tarifárias utilizadas como mecanismos de incentivos no âmbito da regulação econômica.

\subsubsection{Mecanismos de regulação: a questão do regime tarifário ${ }^{17}$}

De início, cumpre registrar, valendo-se da observação levantada por Pires e Piccinini (1998, p.10), que,

"sob a ótica da regulação americana, uma tarifação bem sucedida é aquela que, de maneira geral, tem os seguintes objetivos principais: a) evitar que os preços fiquem abaixo dos custos (incluindo um retorno 'razoável'); b) evitar o excesso de lucros; c) viabilizar a agilidade administrativa no processo de definição e revisão das tarifas; d) impedir a má colocação de recursos e a produção ineficiente; e e) estabelecer preços não-discriminatórios entre os consumidores".

Partindo-se dessa premissa, entre os autores pesquisados, foram identificados cinco modelos básicos de tarifação para o setor elétrico, a saber: tarifação pela taxa de retorno ou pelo custo de serviço; tarifação com base no custo marginal; price cap; regulação por

\footnotetext{
${ }^{17}$ Os conceitos básicos utilizados neste item foram extraídos dos trabalhos de Possas, Ponde e Fagundes (1997), Pires e Piccinini (1998) e Villela e Maciel (1999).
} 
desempenho (yardstick competition ou benchmark) e tarifa pelo preço.

\subsubsection{Tarifação pela Taxa de Retorno}

Também conhecida como "Tarifação pelo Custo do Serviço", foi adotada por longo tempo nos EUA para regular tarifas de serviços públicos, ainda estruturados sob a forma de monopólio natural. Através deste critério, os preços devem remunerar os custos totais e conter uma margem que proporcione uma taxa interna de retorno considerada adequada como custo de oportunidade, ou seja, atrativa para o investidor. Esta regra visa principalmente à obtenção da eficiência distributiva, uma vez que, ao serem igualados custos e receitas, buscam-se evitar que o produtor se aproprie de lucros extras.

Os principais problemas detectados na adoção desse critério são: a) a dificuldade de avaliar custos, que servem de base para a determinação do preço, especialmente devido à assimetria de informações entre empresa(s) e órgão regulador; b) o caráter controvertido da definição dos custos (históricos e de reprodução); e c) a indefinição a priori sobre a taxa de retorno arbitrada. De modo geral, o método é criticado por induzir à ineficiência (falta de estímulo à redução de custos, na ausência de competidores) e possivelmente o sobreinvestimento, além de acarretar elevados custos de regulação (obtenção e processamento de informações, monitoração de desempenho, consultoria, etc).

\subsubsection{Tarifação pelo Custo Marginal}

Para superar as ineficiências acima destacadas, desenvolveu-se o mecanismo de tarifação com base no princípio do Custo Marginal, que procura transferir para o consumidor os custos incrementais necessários para o seu atendimento. A preocupação central é aproximar os preços dos multiprodutos - característica básica do setor elétrico aos seus custos, reduzindo, assim, as ineficiências decorrentes da sub-utilização da capacidade.

As tarifas são, então, diferenciadas de acordo com as distintas categorias de consumidores (residencial, comercial, industrial, rural etc.) com outras características do sistema, tais como estações do ano, horários de consumo, níveis de voltagem, regiões geográficas etc.

As dificuldades principais referem-se a que critério adotar para cobertura dos custos 
fixos e à complexidade necessária sobre custos em geral, com os tradicionais problemas de assimetria de informação envolvidos.

\subsubsection{Price Cap}

Introduzindo no contexto de reestruturação com a privatização realizada na Inglaterra no setor elétrico, este mecanismo de fixação de tarifa compreende uma regra de reajuste por índice público de preços (IP), acompanhada de previsão de redução de custos por aumento de produtividade (conhecido como fator X), para um período prefixado de anos, com o objetivo de estimular, de forma simples e transparente, a busca de aumento de eficiência microeconômica. A fórmula básica pode ser expressa por:

$$
\mathrm{p}=\mathrm{IP}-X
$$

onde p é a tarifa, IP é o índice de preços - originalmente ao consumidor, mas não estritamente necessário - e X um redutor de produtividade predeterminado.

Esse mecanismo pode ainda ser incrementado pelo acréscimo de um componente $\mathrm{Y}$ de "choque de custos", isto é, um fator de repasse de custos para os consumidores, não corriqueiro e basicamente imprevisível, formando a seguinte equação: $\mathrm{p}=\mathrm{IP}-\mathrm{X}+\mathrm{Y}$.

Segundo Pires \& Piccinini (1998), o price cap passou a ser visto como um método tarifário de regra simples e transparente que poderia proporcionar maior grau de liberdade de gestão possível para as empresas em regime de monopólio natural, além de estimular ganhos de produtividade e sua transferência para os consumidores.

Dessa forma, acrescenta os autores, a adoção do price cap contribuiria para reduzir o risco de captura das agências regulatórias (ao não expô-las a uma situação de assimetria de informações) e para incentivar a ação eficiente das firmas, uma vez que, com preços fixos, estas poderiam apropriar-se da redução de custos que viesse a ocorrer entre os períodos revisionais.

Contudo, este método de tarifação requer a definição pelo regulador, de uma série de variáveis relevantes de difícil mensuração, o que também pode comprometer o resultado final esperado. De qualquer maneira, vale a pena registrar tais variáveis: indexador de preços e fator de produtividade; grau de liberdade para a variação de preços relativos; grau de extensão dos repasses dos custos permitidos para os consumidores; e formas de 
incentivo aos investimentos e à qualidade do atendimento.

\subsubsection{Regulação por Desempenho (yardstick competition ou benchmark)}

Baseia-se na introdução de incentivos à maior eficiência pela eliminação de excessos de assimetria de informações quando há várias empresas reguladas, por exemplo, em um mesmo segmento, mas distribuídas em diversas regiões. O desempenho da(s) firma(s) regulada(s) é aferido pela comparação com uma referência média, um benchmark, que induza o acompanhamento de aumentos de produtividade e redução de custos praticados por outras firmas do setor. Um inconveniente é a possível colusão entre essas firmas para apropriar-se de sobrelucros.

\subsubsection{Tarifa pelo Preço}

É definida no âmbito do processo de licitação para exploração dos serviços, segundo o critério do menor preço ofertado. O objetivo desse mecanismo, como sinaliza Pires e Piccinini (1998), é garantir a prestação dos serviços com preços reduzidos, assegurando, também, estímulos à eficiência produtiva, uma vez que condições contratuais incentivarão à redução de custos.

Apesar de ser um instrumento eficaz, no curto prazo, ao permitir que a exploração do serviço seja executada pelo licitante que oferecer o menor preço, seus resultados, no médio prazo, dependerão de uma contínua tarefa de monitoramento e fiscalização, por parte do regulador. Isto porque, a concessionária poderá buscar a apropriação de lucros extraordinários em detrimento de melhorias na qualidade do serviço.

\subsection{Regulação econômica e políticas públicas}

Com esse conjunto de informações, é visível perceber que as transformações, ocorridas nas últimas décadas, reduziram a intervenção direta do Estado na atividade econômica. De fato, aquele Estado-empreendedor, responsável pela produção de diversos bens e serviços, conforme preconizava a teoria keynesiana, cedeu espaço para o Estadoregulador,

"que se preocupa em manter o equilíbrio entre os interesses privados (competição, respeito aos direitos dos usuários, admissão da exploração lucrativa de atividade econômica) com as metas e objetivos de interesse público (universalização, redução de desigualdades, modicidade de preços e tarifas, maiores investimentos etc.)", Marques Neto (s/d, p. 13). 
Essa mudança de função do Estado na economia exige, contudo, não apenas o fortalecimento das agências reguladoras, como forma de fortalecer a si próprio, mas clareza na condução das demais políticas públicas, de maneira a evitar que a ótica de mercado prevaleça nesse novo arranjo institucional.

Como destacado anteriormente, o grande desafio passa pela articulação desses princípios, aceitos e implementados pela maioria dos países em desenvolvimento, a partir das promessas advindas da nova ordem econômica, com uma estratégia própria de crescimento para cada País, que preveja, conforme ressalta Tavares (1999, p. 149), "uma política de inserção internacional com a integração produtiva nacional, dentro de um planejamento estratégico que contemple uma visão sistêmica e holística de desenvolvimento sustentado".

Esse tipo de conduta, entretanto, deve ser recolocado, uma vez que nos últimos anos, de uma maneira geral, a política econômica dos países em desenvolvimento limitouse a privilegiar medidas de curto prazo, voltadas para controle da estabilidade monetária, para a busca de superávit primário nas contas públicas e de saldos positivos na balança comercial, com expressivos programas de privatização.

Assim, a revisão dos mecanismos de gestão pública e da capacidade estratégica dos setores produtivos, bem como da atuação do próprio Estado na economia, com certeza, representam elementos essenciais na construção de um quadro institucional e um marco regulatório estáveis adequados ao processo de reestruturação setorial nas áreas de infraestrutura, particularmente no setor elétrico.

De fato, combinar, por exemplo, uma estratégia de política industrial aos convencionais instrumentos de política macroeconômica, que lidam com o comportamento mais agregado da economia, em fatores como inflação, taxa de juros, carga tributária, investimentos, dentre outros, pode contribuir para construção deste novo cenário de inserção internacional.

Nesses termos, a primeira etapa no encaminhamento desse desafio é conceituar o termo "política industrial". Para isso, será usada como referência a definição estabelecida por Campanário e Silva (2004, p. 13-15), que entendem que "política industrial é a criação, 
a implementação, a coordenação e o controle de instrumentos destinados a ampliar a capacidade produtiva e comercial da indústria, a fim de garantir condições concorrenciais sustentáveis nos mercados interno e externo". Completando, os autores acrescentam que:

"a política industrial, a rigor, procura promover o desenvolvimento de setores econômicos específicos no que se relaciona com geração de divisas, difusão de tecnologias modernas e expansão dos níveis de emprego, corrigindo desajustes de mercado (defesa da concorrência e do consumidor), aumentando a competitividade empresarial e sistêmica e impulsionando o uso mais eficaz dos recursos naturais".

Partindo-se desse conceito, que como levantado pelos autores, busca ser o mais abrangente possível, apontando os diversos elementos presentes nas economias modernas, deve-se avaliar de que maneira os distintos agentes econômicos e, particularmente, o Estado, poderiam contribuir na condução dessa política.

Conforme apresentado no item 1.1 do presente capítulo, a discussão sobre a presença do Estado na economia toma força com a evolução da teoria keynesiana, em especial a partir da crise de 1929, quando ficam evidentes os limites da ação dos mercados na alocação eficiente dos recursos. Na verdade, o grande salto da economia mundial no pós-guerra, viabilizando trinta anos de crescimento econômico, em especial dos países capitalistas desenvolvidos, foi pautado pelo forte intervenção estatal.

Essa ação, entretanto, dá sinais de esgotamento, ao final da década de setenta, dada, entre outros pontos, a fragilidade fiscal de grande parte das economias capitalistas. Em resposta, a partir de meados da década de oitenta, como visto, ganha espaço os princípios norteadores do chamado Consenso de Washington, pautados pela defesa da liberalização de mercados e pela redução das ações estatais na promoção do desenvolvimento econômico, retomando a ênfase liberal na definição dos instrumentos de política econômica.

Com isso, todas as intervenções estatais, representadas por práticas de subsídios e/ou incentivos, a setores industriais específicos e/ou a produtos selecionados, com o intuito de promover sua capacidade produtiva e comercial, com a finalidade de garantir condições concorrenciais nos mercados interno e externo, são prontamente abortadas. Isto porque, aos olhos dos defensores da corrente liberal, tais iniciativas seriam, na maioria das vezes, discricionárias, podendo levar a imperfeições na alocação de recursos, ao eleger 
determinados setores como estratégicos em detrimento dos demais, no desenvolvimento econômico de um país.

Assim, nessa abordagem, que defende o livre funcionamento do mercado, como forma de assegurar a dinâmica da economia, as ações do governo visam à correção apenas de falhas de mercado, que, conforme destacado anteriormente, podem ser entendidas como: a) assimetria de informação; b) existência de externalidades negativa; c) comportamento colusivo ou não otimizante dos agentes; d) indivisibilidades; e) incerteza; f) existência de bens públicos; e g) outras violações das hipóteses neoclássicas para o equilíbrio geral competitivo.

Dessa forma, enquadram-se nesse entendimento, as intervenções estatais classificadas, na bibliografia levantada, como políticas horizontais, que conforme colocado por Alem, Barros e Giambiagi (2002, p. 661-662), "abrangem uma série de medidas que impactam a indústria e, em linhas gerais, a própria economia como um todo". Tais medidas, esclarecem os autores, visam promover a competitividade sistêmica, através da criação de um ambiente macroeconômico favorável para a promoção de investimentos na economia.

Dentre os instrumentos horizontais, que têm impacto no sistema econômico como um todo, destacam-se: a) estabilidade de preços; b) eficiente sistema tributário; c) acesso a fontes de financiamento de longo prazo; d) política de promoção comercial; e) promoção de gastos em pesquisa e desenvolvimento; f) educação e qualificação da mão-de-obra; g) regulação das concessões de serviços públicos; e h) investimentos seletivos em infraestrutura.

Por outro lado, quando o debate avança para abordagens mais intervencionistas, que defendem um Estado mais ativo, a política industrial ganha papel de destaque, dentre os instrumentos de política econômica. Nesse ambiente, políticas verticais ou de promoção a setores específicos, conforme ressaltam Alem, Barros e Giambiagi (2002, p.660-662), seriam "direcionadas a indústrias particulares - e firmas como seus componentes - para atingir os resultados que são percebidos pelo Estado como sendo eficientes para a economia como um todo".

Assim, ao contrário das argumentações levantadas anteriormente, a adoção de políticas industriais setoriais seria capaz de contribuir, de forma estratégica, para o 
desenvolvimento de setores importantes, o que poderia não ocorrer caso as decisões fossem tomadas, exclusivamente, pelo mercado. Nesse novo enfoque, Campanário e Silva (2004, p. 18) ressaltam que "os instrumentos teriam de privilegiar a busca da 'eficiência dinâmica', guiada pelo setor público, em detrimento da 'eficiência alocativa', promovida somente pelos mercados ${ }^{18 \%}$.

Com isso, a política industrial passaria a assumir um papel fundamental na construção de vantagens comparativas, ao agir dinamicamente sobre a atividade econômica. Dentro dessa perspectiva, papéis de maior relevância caberiam ao Estado, "seja como agente estruturante nas novas forças produtivas, seja como propulsor da sua difusão através da sociedade" (Erber, 2002, p. 641). Dessa forma, o estímulo à introdução de inovações tecnológicas e ao aprimoramento das capacitações locais torna-se a orientação das ações verticais, a serem definidas pelo setor público.

Tais ações, segundo Erber (2002, p. 651-653), poderiam ser direcionadas em duas frentes específicas, a saber: para as empresas ou para as cadeias produtivas. No primeiro caso, destacam-se os instrumentos que permitam reduzir, de um lado, custos, através de incentivos fiscais e de crédito, e, de outro, riscos de investimentos, representados por, política de proteção contra as importações, de compras pelo Estado e de aporte de capital de risco.

As ações voltadas para as cadeias produtivas, por sua vez, tenderiam a ser mais flexíveis, ao alocar grande parte de seus recursos em programas setoriais e nas empresas que deles participam. Com isso, teria condições de mobilizar um volume expressivo de recursos públicos, de dar maior eficácia ao uso e estimular as empresas a constituir e participar de programas setoriais, ampliando a cooperação e coordenação entre os agentes, inclusive, as várias entidades públicas.

O êxito dessa opção, entretanto, como alerta Alem, Barros e Giambiagi (2002, p.662), depende de sua associação com as seguintes condutas: a) divulgação pública dos

\footnotetext{
${ }^{18}$ Eficiência dinâmica pode ser entendida como sendo a busca pela capacidade de selecionar inovações de produto e de processo que resultem em redução futura de custos e de preços e em melhoria da qualidade dos produtos. Já o termo eficiência alocativa tornou-se, praticamente, sinônimo de eficiência econômica, ao relacionar o valor comercial de um produto e o custo unitário de sua produção. Assim, quanto maior for essa relação, tanto melhor será alocação dos recursos envolvidos no processo produtivo, verificados em mercados sob concorrência perfeita e em equilíbrio geral.
} 
critérios adotados na definição dos setores selecionados; b) anúncio dos benefícios e dos custos macroeconômicos do apoio a esses setores; c) cobrança de desempenho; d) estabelecimento de prazo para esse apoio; e e) transparência na divulgação dos resultados previstos e realizados.

Esse comportamento, acredita Erber (2004), constitui um elemento importante do desenvolvimento, ao passar por coalizões estratégicas entre o Estado, empresas e outros segmentos da sociedade civil, privilegiando mecanismos de políticas que, de um lado, reduzam riscos e favoreçam a ação coletiva, e, de outro, supram os serviços sociais básicos e reduzam as disparidades regionais.

Do exposto, percebe-se claramente que as ações governamentais, classificadas como políticas horizontais, foram, nas últimas duas décadas, amplamente difundidas e implementadas em diversos países, variando apenas a intensidade e a eficiência, na condução de cada uma delas. Na verdade, sua adoção segue o receituário padrão defendido pelo Fundo Monetário Internacional - FMI, particularmente entre os países em desenvolvimento, onde a atuação do Estado passou a limitar-se a "estabelecer fundamentos macroeconômicos 'corretos e sólidos' e um quadro institucional favorável ao mercado" (Erber, 2002, p.640).

De fato, o controle obsessivo pela estabilidade de preços e pelo equilíbrio fiscal, centrado no esforço constante de se alcançar as metas inflacionárias e superávits fisscais, foi a marca das políticas públicas de diversos países em desenvolvimento, durante os anos 90 . Nesse ambiente, redução e controle dos gastos públicos, inclusive dos investimentos produtivos estatais, encontram na implementação dos programas de privatização e na criação de um sistema institucional eficiente relacionado à regulação dos serviços públicos, uma forte complementaridade às políticas horizontais em curso, quando se enfoca o papel do Estado na área de infra-estrutura.

Dessa forma, resgatar o papel do Estado na rearticulação do quadro institucional, de maneira a sair fortalecido na coordenação da política energética nacional é de fundamental importância. No fundo, esse tipo de discussão recoloca a própria estratégia de reestruturação do setor elétrico nacional, ao avaliar que tipo de modelo organizacional se pretende e como esse setor pode ser contemplado por políticas verticais ativas, voltadas, 
por exemplo, para a promoção da expansão de sua capacidade instalada, bem como para revisão da inserção do país no cenário mundial, tendo em vista a relevância que o insumo energia deve assumir em um processo de retomada do crescimento econômica nacional.

Assim, é a partir desta ênfase que se pretende desenvolver a análise do setor elétrico brasileiro, na tentativa de se identificar o desenho institucional/organizacional e o papel das políticas públicas neste novo contexto.

De maneira a atender essa finalidade, nos próximos capítulos será mapeada a evolução setor elétrico brasileiro, com o objetivo de consolidar um quadro geral deste segmento da infra-estrutura nacional, para ao final explicitar algumas articulações possíveis, dentre os instrumentos de políticas verticais disponíveis, visando contribuir no debate que envolve o modelo de reestruturação em curso no Brasil. 


\section{CAPÍTULO 2: O ESTADO E O DESENVOLVIMENTO DO SETOR ELÉTRICO BRASILEIRO: as políticas públicas durante o período de 1934 a 1989}

\subsection{Introdução}

No capítulo anterior, foi feita uma síntese da evolução do pensamento econômica, tendo como pano de fundo o debate entre mercado e intervenção estatal, bem como regulação econômica e políticas públicas. Do exposto, fica evidente a marcante presença do Estado nas atividades econômicas, legitimada pelos princípios que nortearam a base da teoria keynesiana, particularmente no período compreendido entre a $2^{\mathrm{a}}$ Guerra Mundial e a década de 70, garantindo, assim, as bases do desenvolvimento interno de várias economias.

A aguda crise dos anos oitenta, entretanto, revela os limites e a fragilidade desta opção, particularmente em diversos países da América Latina, que são forçados a implantar um amplo conjunto de reformas em suas economias, na tentativa de reequilibrarem suas contas. Com a adoção de medidas austeras, marcadas pela redução de gastos correntes e investimentos, leva-se ao limite às possibilidades de utilização dos instrumentos fiscais disponíveis, dada à prioridade pelo controle/redução da dívida pública.

Esse mesmo tipo de movimento pode ser verificado para o caso do setor elétrico brasileiro. Assim, o presente capítulo terá a preocupação de resgatar o processo de implantação da indústria de energia elétrica no Brasil, através de sua evolução histórica, destacando seu arcabouço legal, jurídico e institucional. Para atingir este objetivo, foram usados, como principais referências básicas, os diversos trabalhos realizados por José Luiz Lima que, desde meados da década de 70, tornou-se um estudioso desse segmento da infraestrutura brasileira.

\subsection{A formação do setor elétrico brasileiro: do nacionalismo implacável do Presidente Getúlio Vargas à criação da Eletrobrás.}

Até os anos 30, poucas tentativas foram realizadas pelos governos brasileiros, no sentido de impulsionar a industrialização no país. De fato, nesse período, o foco da política econômica nacional era a estabilidade monetária, o equilíbrio orçamentário do governo federal e, principalmente, a defesa dos interesses do setor agroexportador. Na verdade, a 
prioridade com o setor externo fundamentava-se no peso relativo que este exercia na estrutura econômica interna, da maioria dos países latino-americanos, que chegou a ser classificado por Tavares (1982) como um "modelo de desenvolvimento voltado para fora", cujas características centrais podem ser assim sintetizadas:

“a) a exportação é a variável quase que exclusiva na determinação da Renda Nacional e sua única fonte de dinamismo;

b) a pauta de exportações possui base estreita, isto é, ela é fortemente concentrada em poucos produtos primários ${ }^{19}$;

c) as importações constituem uma fonte flexível de suprimento de bens para atender a boa parte da demanda interna;

d) a pauta de importações inclui não apenas produtos e matéria-prima de origem natural, não disponíveis no país, como também bens de consumo e de capital;

e) existe grande diferença entre a base produtiva (produtos para exportação) e a estrutura da demanda, que precisa ser atendida pelas importações" (Gremaud, et alii, 2005, p. 347).

Tal modelo, ao ter o setor exportador como o elo dinâmico da economia nacional, revela uma forte dependência externa e uma vulnerabilidade, ainda maior, às condições do mercado internacional dos produtos exportados, tendo em vista que praticamente todas as demais atividades dentro do país dependiam direta ou indiretamente do desempenho desse setor.

Dessa forma, um fraco desempenho das exportações brasileiras, como resultado de uma tendência mundial desfavorável ao mercado de produtos primários, principalmente alimentos e matérias-primas, poderia trazer conseqüências ao balanço de pagamentos, ao implicar queda nas importações, comprometendo diretamente o consumo da economia.

Foi exatamente esta relação de dependência com o setor externo, que, durante as décadas de 30 e 40, como reação à crise de 1929 e, posteriormente, à 2a Guerra Mundial, levou às autoridades econômicas, orientadas exatamente por dificuldades no balanço de pagamentos, a perceberem que não poderiam contar apenas com as exportações de seus produtos primários para alcançar suas ambições de desenvolvimento, em especial dado o longo período que transcorreu até a plena recuperação do mercado mundial.

\footnotetext{
${ }^{19}$ Apenas para ilustrar temos que, em 1929, o café como sendo responsável por $71 \%$ do total das exportações brasileiras, Baer (1996).
} 
Assim, com a intenção muito maior de defender o mercado interno, dos efeitos da crise do mercado internacional, do que estimular a atividade interna, uma série de medidas foi adotada, com esse propósito, das quais se destacam: restrições e controle das importações; elevação da taxa de câmbio e compra de excedentes ou financiamento de estoques.

Essa estratégia, conforme destaca Tavares (1982), iniciada em resposta às limitações externas, garantiu a passagem para um novo modelo de desenvolvimento, "voltado para dentro", estimulando, dessa maneira, o processo interno de industrialização conhecido como "modelo de substituição de importações ${ }^{20 ", ~ q u e ~ a c a b o u ~ p o r ~ p e r m i t i r, ~}$ apesar da ausência de um planejamento plenamente integrado, uma diversificação da indústria nacional.

Tabela 2.1.

Mudanças na estrutura de importações brasileiras, 1901-1929 (percentagens anuais médias)

\begin{tabular}{|l|c|c|c|}
\hline \multicolumn{1}{|c|}{ Categorias de Importação } & $\mathbf{1 9 0 1 - 1 0}$ & $\mathbf{1 9 1 1 - 2 0}$ & $\mathbf{1 9 2 1 - 2 9}$ \\
\hline Mineração & 6,2 & 8,8 & 5,5 \\
\hline Manufaturas & 83,6 & 78,7 & 80,8 \\
\hline Produtos Metalúrgicos & 12,3 & 13,0 & 13,8 \\
\hline Maquinário & 4,8 & 4,7 & 7,4 \\
\hline Equipamento elétrico & 1,0 & 1,8 & 3,0 \\
\hline Equipamento de transportes & 2,6 & 4,0 & 8,0 \\
\hline Químicos & 5,6 & 9,0 & 11,9 \\
\hline Produtos têxteis & 15,1 & 10,9 & 12,1 \\
\hline Produtos alimentícios & 19,4 & 12,8 & 8,9 \\
\hline Bebidas & 6,0 & 4,1 & 2,1 \\
\hline Produtos não-industrializados (principalmente & 10,2 & 12,5 & 13,7 \\
\hline TOTAL & $\mathbf{1 0 0 , 0}$ & $\mathbf{1 0 0 , 0}$ & $\mathbf{1 0 0 , 0}$ \\
\hline
\end{tabular}

Fonte: Baer (1996, p.52) apud Villela et aliii (1971, p.115) "Aspectos do crescimento da economia brasileira, 1889-1969".

Como resultado da economia brasileira ter sido obrigada a voltar-se sobre si mesma e desenvolver novas atividades produtivas, percebe-se uma mudança tanto na pauta de importações brasileiras, ampliando a participação do segmento de bens intermediários e de

\footnotetext{
${ }^{20}$ Tavares (1982, p.41), em seu clássico livro Da substituição de importações ao capitalismo financeiro. ensaios sobre economia brasileira, da Zahar Editores, esclarece que o termo substituição de importações deve ser utilizado para "caracterizar um processo de desenvolvimento interno que tem lugar e se orienta sob o impulso de restrições externas e se manifesta, primordialmente, através de uma ampliação e diversificação da capacidade produtiva industrial".
} 
capital em detrimento dos segmentos relacionados a produtos alimentícios, têxteis e bebidas, como na distribuição da estrutura produtiva interna, o que acabou por transformar a indústria em uma força capaz de impulsionar a economia nacional.

Tabela 2.2.

A estrutura industrial brasileira em 1919 e 1939

(distribuição percentual do valor agregado total)

\begin{tabular}{|l|c|c|}
\hline \multicolumn{1}{|c|}{ Setor } & $\mathbf{1 9 1 9}$ & $\mathbf{1 9 3 9}$ \\
\hline Minerais não metálicos & 5,7 & 5,2 \\
\hline Produtos de Metal & 4,4 & 7,6 \\
\hline Maquinário & 0,1 & 3,8 \\
\hline Equipamentos Elétricos & - & 1,2 \\
\hline Equipamentos de Transportes & 2,1 & 0,6 \\
\hline Produtos de Madeira & 4,8 & 3,2 \\
\hline Móveis & 2,1 & 2,1 \\
\hline Produtos de papel & 1,3 & 1,5 \\
\hline Produtos de borracha & 0,1 & 0,7 \\
\hline Produtores de couro & 1,9 & 1,7 \\
\hline Químicos & $1,7 *$ & $*$ \\
\hline Farmacêuticos & $1,2^{*}$ & $*$ \\
\hline Perfumes, sabonetes e velas & $0,7 *$ & $*$ \\
\hline Têxteis & 29,6 & 22,2 \\
\hline Roupas e calçados & 8,7 & 4,9 \\
\hline Produtos alimentícios & 20,6 & 24,2 \\
\hline Bebidas & 5,6 & 4,4 \\
\hline Fumo & 5,5 & 2,3 \\
\hline Editoras e material gráfico & 0,4 & 3,6 \\
\hline Diversos & 3,5 & 1,0 \\
\hline TOTAL & $\mathbf{1 0 0 , 0 0}$ & $\mathbf{1 0 0 , 0 0}$ \\
\hline
\end{tabular}

* Em 1919, a percentagem dessas três categorias juntas foi de 3,6; em 1939, totalizou 9,8. Fonte: Baer (1996, p. 56)

Visando ilustrar essa alteração, acima são reproduzidos alguns dados comparativos, levantados por Baer (1996), entre as estruturas industriais existente no Brasil em 1919 e 1939. A Tabela 2.2. sinaliza que a base produtiva nacional, em 1919, era dominada por indústrias leves, assim distribuídas: têxteis $(29,6 \%)$; roupas e calçados $(8,7 \%)$; produtos alimentícios $(20,6 \%)$; bebidas $(5,6 \%)$ e fumo $(5,5 \%)$. No conjunto, tais setores totalizavam $70 \%$ da produção nacional. Em 1939, entretanto, esse grupo reduziu sua participação para $58 \%$, com o crescimento de setores relacionados à metalurgia, equipamentos elétricos e equipamentos de transportes, revelando o mesmo comportamento das mudanças ocorridas 
na pauta de importação brasileira, ao longo do período 1901-1929, conforme demonstrou a tabela 2.1, acima detalhada.

Evidentemente, que essa mudança no perfil da indústria nacional impactou no consumo de eletricidade ${ }^{21}$. Entretanto, como aponta Lima (1989, p. 28), as informações, relativas a esse tipo de consumo de eletricidade, nesta fase do processo de industrialização brasileira, limitam-se ao realizado nas áreas de concessão do Grupo Light, representativas dos mercados mais dinâmicos da economia nacional, São Paulo e Rio de Janeiro, em anos selecionados.

Tabela 2.3.

Grupo Light: Consumo de Energia Elétrica, para anos selecionados

\begin{tabular}{|c|c|c|c|}
\hline Ano & $\begin{array}{c}\text { S.P. Light } \\
(\text { GWh })\end{array}$ & $\begin{array}{c}\text { R.J. Light } \\
(\text { GWh })\end{array}$ & $\begin{array}{c}\text { Grupo Light } \\
(\text { GWh })\end{array}$ \\
\hline 1920 & 165 & 276 & 441 \\
\hline 1930 & 478 & 397 & 875 \\
\hline 1940 & 1.111 & 721 & 1.832 \\
\hline
\end{tabular}

Fonte: Lima (1989, p.29), apud Castro, Nivalde J. de O setor de energia elétrica no Brasil: a transição da propriedade privada para a propriedade pública (1945-1961).

Percebe-se, a partir da Tabela 2.3., que o consumo de energia elétrica cresceu $573,3 \%$ na área de concessão de São Paulo, contra apenas um aumento de $161 \%$ verificado no Rio de Janeiro, durante o mesmo período. Este resultado parece indicar o movimento de aumento na demanda de energia, em função do forte processo de expansão industrial, que, de fato, o Estado de São Paulo vivenciou nesta fase, registrando, em 1940, 60\% do consumo de energia do Grupo Light, limitado a 37,4\%, em 1920.

\footnotetext{
${ }^{21}$ Cumpre ressaltar, conforme consta do texto História \& Energia (1996, p. 28/29), que a indústria elétrica, como atividade organizada, surgiu no país ao final do século XIX, através da iniciativa de empreendedores nacionais e de governo municipais, em pequenas localidades que se destacavam no cenário econômico da época, ganhando um novo dinamismo apenas com a chegada dos grandes grupos estrangeiros aos principais centros urbanos. Durante a década de 20, no entanto, em paralelo ao processo de industrialização nacional, verifica-se um movimento de concentração empresarial em torno das concessionárias estrangeiras, que passaram a adquirir a maioria das empresas privadas nacionais e municipais existentes, resultando na forte atuação de dois grupos: a) holding Brazilian Traction, Light and Power Co. Ltd, que controlava a produção, a transmissão e a distribuição da energia elétrica nas cidades do Rio de Janeiro e São Paulo; e b) American Share Foreign Power Company - AMFORP, filial da American Bond and Share, que controlava a geração e a distribuição de energia elétrica no interior do estado de São Paulo e arredores, em Porto Alegre, Pelotas, Salvador, Recife, Natal, Vitória e interior do estado do Rio de Janeiro. As demais localidades eram atendidas por pequenos concessionários locais e pelos governos municipais e estaduais, em sistemas elétricos isolados, dificultando o registro de dados daquele período Apenas para ilustrar essa concentração, o BNDES (2002, p.19) explicita que "no início da década de 30, a participação da Light e da Amforp, no parque gerador nacional, era superior a 50\%".
} 
Em suma, a dinâmica do crescimento da economia brasileira, a partir de 1933 e por um período de 20 anos aproximadamente, conforme destaca Lima (1995, p. 32), valendo-se das conclusões de Tavares (1982), caracterizou pela combinação de dois fatores, a saber:

"De um lado, a acumulação de capital passava a ser comandada pelo processo de expansão industrial, onde o segmento de renda urbano era o melhor determinante das condições de demanda efetiva. De outro, o desenvolvimento das forças produtivas e os suportes internos da acumulação urbana não eram suficientes para a implantação da indústria de base, sem a qual o crescimento da capacidade produtiva não poderia acompanhar o incremento da demanda".

Tabela 2.4.

Evolução de indicadores econômicos selecionados ${ }^{(*)}$

(1925-1945)

\begin{tabular}{|c|c|c|c|c|c|c|}
\hline \multirow{3}{*}{ ANO } & \multirow{2}{*}{\multicolumn{3}{|c|}{ Potência Instalada }} & \multirow{3}{*}{ PIB (\%) } & \multirow{3}{*}{$\begin{array}{l}\text { Produto } \\
\text { Industrial }\end{array}$} & \multirow{3}{*}{$\begin{array}{l}\text { Produto } \\
\text { Agrícola }\end{array}$} \\
\hline & & & & & & \\
\hline & Total & Hidráulic & Térmica & & & \\
\hline 1925 & 507 & 417 & 90 & 0,0 & 1,1 & $-3,2$ \\
\hline 1926 & 592 & 489 & 103 & 5,2 & 2,4 & 3,2 \\
\hline 1927 & 650 & 539 & 111 & 10,8 & 10,8 & 10,8 \\
\hline 1928 & 707 & 576 & 131 & 11,5 & 7,0 & 18,4 \\
\hline 1929 & 760 & 622 & 138 & 1,1 & $-2,2$ & 0,3 \\
\hline 1930 & 779 & 630 & 149 & $-2,1$ & $-6,7$ & 1,2 \\
\hline 1931 & 799 & 646 & 153 & $-3,3$ & 1,2 & $-6,3$ \\
\hline 1932 & 805 & 649 & 156 & 4,3 & 1,4 & 6,0 \\
\hline 1933 & 817 & 658 & 159 & 8,9 & 11,7 & 12,0 \\
\hline 1934 & 828 & 665 & 163 & 9,2 & 11,1 & 6,2 \\
\hline 1935 & 850 & 677 & 173 & 3,0 & 11,9 & $-2,5$ \\
\hline 1936 & 925 & 746 & 179 & 12,1 & 17,2 & 9,5 \\
\hline 1937 & 947 & 755 & 192 & 4,6 & 5,4 & 0,1 \\
\hline 1938 & 1162 & 947 & 215 & 4,5 & 3,7 & 4,2 \\
\hline 1939 & 1176 & 952 & 224 & 2,5 & 9,3 & $-2,3$ \\
\hline 1940 & 1244 & 1009 & 235 & $-1,0$ & $-2,7$ & $-1,8$ \\
\hline 1941 & 1261 & 1019 & 242 & 4,9 & 6,4 & 6,3 \\
\hline 1942 & 1308 & 1061 & 247 & $-2,7$ & 1,4 & $-4,4$ \\
\hline 1943 & 1315 & 1067 & 248 & 8,5 & 13,5 & 7,3 \\
\hline 1944 & 1334 & 1077 & 257 & 7,6 & 10,7 & 2,4 \\
\hline 1945 & 1342 & 1080 & 262 & 3,2 & 5,5 & $-2,2$ \\
\hline
\end{tabular}

(*) Os dados apresentados para o PIB, os produtos industrial e agrícola referem-se à variação em relação ao ano anterior, disponibilizados em Abreu (1990). No caso da potência instalada, os dados foram extraídos de Lima (1989, p. 31).

Os dados da Tabela 2.4 evidenciam a expansão do produto industrial, que, em especial a partir da década de 30 , dá sinais de efetivo crescimento, em detrimento dos oscilantes resultados do produto agrícola, em igual período, o que acabou por impulsionar o cenário urbano nacional.

Neste novo ambiente é que a preocupação, com o planejamento e a redefinição do 
papel do Estado, torna-se imprescindível para garantir o processo de crescimento econômico nacional. Particularmente no caso do setor elétrico, ganham espaço as correntes favoráveis a sua nacionalização. Isto porque, o crescimento da população urbana e o avanço da indústria, do comércio e dos serviços acabam por pressionar à ampliação da capacidade instalada que, infelizmente, em decorrência das diversas restrições e dificuldades ocasionadas pelas crises externas, passam a crescer a um ritmo menor do que o necessário para atender a este incremento na demanda.

Em resposta, aumenta o poder de regulamentação sobre esses serviços, representado, de acordo com o BNDES (2002, p. 4), pelas seguintes iniciativas:

"a interrupção dos processos de autorização de novos aproveitamentos dos cursos de água; a proibição de aquisição de empresas; e a extinção da cláusula-ouro, mecanismo que era utilizado desde o primeiro contrato com a São Paulo Light e que garantia às empresas o reajuste sistemático das tarifas pela cotação do ouro.”

$\mathrm{Na}$ verdade, apesar de tais mudanças, foi apenas com a formalização do Código de Águas, promulgado com a publicação do Decreto 24.643, de 10 de julho de 1934, que se materializa o primeiro projeto voltado para a gestão do setor de águas e energia elétrica nacional.

Baseada nas mesmas doutrinas e práticas vigentes nos países de origem dos grupos estrangeiros instalados no Brasil, a nova legislação transfere para a União a competência para legislar e outorgar concessões de serviços públicos de energia, antes regidos apenas por contratos assinados com os estados, os municípios e o Distrito Federal. Ademais, a nova política setorial, ao rever os critérios para o estabelecimento da remuneração desses serviços, estabelece que a tarifa seja fixada na forma de "serviço pelo custo", a fim de garantir ao prestador do serviço a cobertura das despesas de operação e das cotas de depreciação e de reversão e a justa remuneração do capital investido ${ }^{22}$.

O Código de Águas definiu, ainda, que as autorizações ou concessões seriam conferidas exclusivamente a brasileiros ou a empresas organizadas no Brasil, refreando,

\footnotetext{
${ }^{22}$ Ressalte-se que a remuneração e a depreciação dos bens das concessionárias, conforme aponta o BNDES (2002), seria calculado com base no custo histórico das instalações, e não sobre o custo de reprodução ou reposição, como defendia a Light, maior companhia de energia elétrica instalada no país. Ademais, o pagamento da remuneração aos concessionários seria efetuado em moeda nacional, eliminando, definitivamente, a chamada cláusula-ouro.
} 
assim, a participação de novas companhias internacionais no setor. Além disso, a concessão e autorizações de exploração da energia hidráulica, assim como os serviços complementares de transmissão, transformação e distribuição seriam permitidos às empresas privadas, mas com reversão do patrimônio da concessionária privada ao poder concedente (Estado), ao final do contrato de concessão, em geral de longo prazo.

Estas medidas desestimularam os empresários que, em associação às restrições impostas, em razão da Segunda Guerra Mundial, nas importações de máquinas e equipamentos, reduziram o ritmo de expansão da capacidade instalada, em descompasso com o crescimento do consumo ${ }^{23}$, levando ao racionamento nas cidades de São Paulo e Rio de Janeiro.

Dadas estas variáveis, era patente a necessidade de se expandir o setor elétrico, que, a depender da sua evolução, poderia representar uma barreira ao desenvolvimento. Essa questão torna-se, portanto, um problema nacional e passa a envolver, cada vez mais, o Estado. A própria regulamentação do Código de Águas parece sinalizar essa nova relação entre o Estado e o setor, ao criar condições, inclusive, para a formulação de programas de desenvolvimento, conforme diagnosticado pela Missão Cooke (1942-1943) ${ }^{24}$ e pela Missão Abbink (1948) ${ }^{25}$, em particular para a constituição do setor produtivo estatal.

Com a posse do Presidente Eurico Gaspar Dutra, em janeiro de 1946, o Congresso Nacional voltou-se para a elaboração da 4 a Constituição Republicana do Brasil. Tendo sido promulgada em setembro de 1946, não introduziu modificações substantivas em relação às constituições de 1934 e 1937. Especificamente ao setor elétrico, a nova Carta, conforme destaca Lima (1995, p. 53), "por um lado, vinculava a situação legal das concessionárias à regulamentação do Código de Águas e, por outro, antecipava a forma de tributação dos

\footnotetext{
${ }^{23}$ Segundo o BNDES (2002, p. 19), "nos períodos de 1930-1940 e 1940-1945, o consumo de energia elétrica, nas cidades de São Paulo e Rio de Janeiro, cresceu 8,6\% e 8,7\%, respectivamente, ao ano", acarretando racionamentos nos anos seguintes, dado o descompasso entre a demanda e a capacidade de geração. Essa situação perdurou até o início da década de 60.

24 De acordo com Lima (1995, p. 57), “a Missão Cooke foi organizada em 1942 em decorrência do posicionamento brasileiro em favor das tropas aliadas e visava definir as prioridades da infra-estrutura e da indústria brasileiras em termos das necessidades de adaptação às restrições impostas pelo conflito mundial".

${ }^{25}$ A Missão Abbink foi o nome como acabou ficando conhecida a Comissão Técnica Mista BrasileiroAmericana de Estudos Econômicos, organizada em 1948, e chefiada, do lado dos EUA, por John Abbink. Formulada na mesma época em que o Plano Marshall de reconstrução da Europa e do Japão encontrava-se em pleno andamento, teve a função, no Brasil, de "transmitir seu apoio aos objetivos do Plano Salte e foi além da Missão Cooke no detalhamento de algumas diretrizes no campo da energia”, Lima (1995, p. 58).
} 
energéticos com base na figura do imposto único".

Ademais, a gestão Dutra foi extremamente conservadora em termos de ação governamental, não dando prioridade nem para o avanço do processo de industrialização, nem para a eventual reestruturação do modelo primário-exportador. Tal postura, como bem assinala Lessa (1983), revela-se na prática liberal de importações que, entre os anos de 1945/47, permitiu a "queima" de reservas cambiais, conseguidas durante a época do conflito mundial (ver Tabela 2.5.). Esta situação conduziu Brasil, em 1947, para uma nova situação de estrangulamento externo, resultando em um déficit em transações correntes, da ordem de US\$ 151 milhões.

Tabela 2.5.

Principais Rubricas do Balanço de Pagamentos Brasileiros 1937-1947

\begin{tabular}{|c|c|c|c|c|c|}
\hline Ano & Exportações & Importações & $\begin{array}{c}\text { Saldo da Balança } \\
\text { Comercial }\end{array}$ & $\begin{array}{l}\text { Saldo da Balança } \\
\text { de Serviços }\end{array}$ & $\begin{array}{l}\text { Saldo da } \\
\text { Conta } \\
\text { Corrente }\end{array}$ \\
\hline 1937 & 346,8 & 279,2 & 67,6 & $-130,9$ & $-63,3$ \\
\hline 1938 & 294,3 & 246,5 & 47,8 & $-43,4$ & 4,4 \\
\hline 1939 & 299,9 & 218,0 & 81,9 & $-53,5$ & 28,4 \\
\hline 1940 & 252,1 & 200,7 & 51,4 & $-63,7$ & $-12,3$ \\
\hline 1941 & 367,7 & 222,5 & 145,2 & $-53,5$ & 91,7 \\
\hline 1942 & 409,8 & 177,4 & 232,4 & $-31,1$ & 201,3 \\
\hline 1943 & 472,6 & 226,9 & 245,7 & $-47,2$ & 198,5 \\
\hline 1944 & 580,3 & 310,4 & 269,9 & $-84,1$ & 185,8 \\
\hline 1945 & 655,1 & 322,5 & 332,6 & $-84,4$ & 248,2 \\
\hline 1946 & 985,0 & 594,0 & 391,0 & $-203,0$ & 188,0 \\
\hline 1947 & $1.157,0$ & $1.027,0$ & 130,0 & $-218,0$ & $-151,0$ \\
\hline
\end{tabular}

Fonte: extraído de Abreu (1990, p. 398-399), elaborado a partir de Boletins do BACEN.

É por este motivo que a gestão do Presidente Dutra, período 1947/50, traduz a fase reconhecida como "industrialização não intencional", caracterizada pelo movimento de industrialização predominantemente extensiva e pouco coordenada ${ }^{26}$, uma vez que os avanços na estrutura industrial limitaram-se, basicamente, à faixa de consumo duráveis e

\footnotetext{
${ }^{26}$ Cumpre destacar que a expressão "industrialização não intencional” foi utilizada por Lessa, em sua obra 15 anos de política econômica, com o objetivo de demonstrar que mesmo na ausência de uma ação governamental integrada, capaz de direcionar adequadamente a política de "substituição de importações", o processo de industrialização evoluiu. Esclarece que, de maneira não intencional, o governo contribuiu, através da política de restrição às importações, para os investimentos privados na indústria, em especial na faixa de bens de consumo, dada a reserva de mercado.
} 
indústria leve de bens de produção ${ }^{27}$.

Assim, o saldo foi um crescimento do produto industrial a taxas em torno de $11 \%$ a.a., mas com o agravamento das condições de infra-estrutura, especialmente de transporte e energia, em decorrência das limitações de investimentos nesta área, em especial do setor público, uma vez que, como bem coloca Lessa (1983), "não esteve aparelhado, nem financeira, nem institucionalmente, para fazer frente às crescentes necessidades de capital".

Cumpre ressaltar ainda que, do ponto de vista do setor elétrico, poucos investimentos foram realizados neste período ${ }^{28}$. O próprio Plano Salte (Saúde-AlimentaçãoTransporte-Energia), aprovado em 1950 e que designava 16\% de seus recursos para Energia, sendo $52 \%$ destinado ao subsetor eletricidade, $47 \%$ ao petróleo e o restante em exploração carbonífera, acabou não sendo executado. De fato, conforme análise efetuada por Lima (1985), o Plano não ataca o problema de escassez adequadamente, uma vez que “na apresentação dos investimentos não havia menção sequer aos acréscimos de capacidade instalada que o programa de obras poderia proporcionar". Além disso, as aplicações em energia elétrica apareciam esparsas, desintegradas e desvinculadas de regiões, como a sudeste, em que a falta de energia poderia tornar-se cada vez mais crônica.

Na verdade, conforme colocado por Lima (1995), citando Draibe (1985),

"o Plano Salte retrata de maneira exemplar as forças sociais e a articulação política dominante no período. Tal como aquelas, o Plano não será anti-industrializante, não elegerá a agricultura como o caminho privilegiado que conduzirá o futuro. Mas, também como aquelas, não terá a industrialização como meta central e requerimento urgente da Nação. A lentidão do desenvolvimento seria o seu resultado".

Em resposta a esta posição, em 1950, Getúlio Vargas, centrando sua campanha em um discurso que, de um lado, defendia a política desenvolvimentista, conduzida durante o período do Estado Novo (1930-1945) e, de outro, atacava a estratégia ortodoxa da política econômica adotada no Governo Dutra, alcança a vitória, tornando-se, novamente, Presidente da República.

\footnotetext{
${ }^{27} \operatorname{Lima}(1983)$.

${ }^{28}$ Lima (1983) ressalta que as medidas governamentais de maior impacto, neste setor, limitaram-se a questões administrativas.
} 
Com esta mudança de poder, reforça, também, a possibilidade de reformulação da política econômica nacional, que retoma sua orientação para o desenvolvimento industrial. Entre os fatores que favoreceram esta conduta, podem ser lembrados, valendo-se de Lessa (1983), os seguintes:

a) pressão por melhoria dos serviços básicos, em especial, na infra-estrutura de energia e transportes, dada a falta de investimentos realizados no período anterior;

b) circunstância da Guerra da Coréia podendo, a exemplo do que ocorreu durante a Segunda Guerra Mundial, comprometer o abastecimento interno de produtos especiais importados; e

c) providências estimuladoras do desenvolvimento industrial não afetariam interesses nem internos nem externos, em razão do movimento natural do processo econômico, que vinha se desenrolando.

Além disso, de acordo com Vianna (1990),

"a vitória de Getúlio Vargas nas eleições de outubro de 1950 parece ter acelerado a disposição norte-americana de colaborar com o vasto programa de equipamento e expansão de setores de infra-estrutura básica, que o governo brasileiro vinha propondo insistentemente desde o final da guerra".

Dessa forma, em dezembro de 1950, foi constituída a Comissão Mista Brasil-EUA CMBEU, que atuou no período de julho de 1951 a julho de 1953, com a finalidade central de formular "programas concretos de investimento, destinados à eliminação de pontos de estrangulamento na produção de energia elétrica, nos sistemas de transporte pesado e na produção de combustíveis, capazes de entorpecer o ritmo do progresso econômico ${ }^{29}$ ".

Tais programas seriam financiados por instituições como o Banco de Exportação e Importação (Eximbank) e o Banco Internacional de Reconstrução e Desenvolvimento (BIRD). A contrapartida de recursos em moeda nacional seria proporcionada pelo Programa de Reaparelhamento Econômico, criado pela Lei 1.474, de 26/11/1951, com o objetivo de gerar fontes internas de financiamento, compostas basicamente de recursos de ordem fiscal, obtidos mediante alíquotas adicionais sobre o imposto de renda, para projetos

\footnotetext{
${ }^{29}$ Lima (1995, p. 57), citando o Relatório Geral da CMBEU para o Desenvolvimento Econômico.
} 
ligados à infra-estrutura, em especial nas áreas de portos, ferrovias, sistemas de energia elétrica, além de agricultura e armazenagem, bem como indústrias de base.

Em 1952, foi criado o Banco Nacional de Desenvolvimento Econômico - BNDE, que se tornou a entidade nacional de financiamento e execução do Programa de Reaparelhamento, associando-se à CMBEU na elaboração e discussão dos projetos setoriais.

Do ponto de vista do setor elétrico, a Comissão Mista identificou quatro fatores como sendo responsáveis pelas causas das crises sistemáticas de fornecimento de energia elétrica. Foram eles: acelerado processo de urbanização, rápido crescimento industrial, controle sobre as tarifas de energia elétrica e tendência ao predomínio do petróleo e da eletricidade sobre fontes de energia convencionais na matriz energética brasileira. Como resultado tem-se um descompasso entre a demanda, que cresce de forma geométrica, e a oferta, que não possui incentivos para garantir investimento necessário à ampliação desses serviços. De 1943 a 1953, por exemplo, de acordo com Rodrigues e Dias (1994, p. 59), “a capacidade instalada aumentou a uma média anual de $1,95 \%$, enquanto a produção cresceu $2,56 \%$ ao ano, taxas inferiores à de crescimento do mercado, acumulando um déficit de oferta estimado na época em cerca de 1.000 MW".

Dessa forma, as principais ações sinalizadas pela CMBEU, com a finalidade de reverter este quadro, foram: i) reexame das relações Estado-concessionárias; ii) implementação dos dispositivos do Código de Águas; iii) definição da política de atração do capital e da técnica necessários à expansão do setor; e iv) necessidade de recuperar as condições de rentabilidade da prestação dos serviços. Em paralelo, sugeriu, também, que o Estado deveria reservar-se papel regulador e supletivo na expansão do setor de energia elétrica e canalizar seus esforços para áreas tradicionalmente reservadas à atuação do setor público, como educação, saúde e transportes.

Pelo visto, a sugestão levantada pela CMBEU, no início da década de 50, em muito se assemelha às saídas defendidas pelas instituições internacionais, leia-se Banco Mundial e FMI, durante a década de 90, em pleno final do século XX, quando da condução do processo de reestruturação do setor elétrico brasileiro, conforme será avaliado no próximo capítulo. O grande desafio, no entanto, em ambos os momentos históricos, parece ser a 
criação de um ambiente confortável para a participação da iniciativa privada, através da definição de um aparato institucional e regulatório, capaz de criar condições seguras para atrair recursos privados para o setor e, ao mesmo tempo, remunerar, adequadamente, os investimentos realizados. Essa equação, na verdade, não é de fácil solução, uma vez que se trata de um serviço público, cujo acesso deve ser garantido a toda a sociedade.

E foi exatamente devido a tais dificuldades, que, aos poucos, as empresas públicas passam a assumir a expansão da capacidade geradora do Brasil. A Tabela 2.6. retrata o programa de energia elétrica por grupo de empresas, no período 1952-1957.

Tabela 2.6

Comissão Mista Brasil - Estados Unidos

Programa de Energia Elétrica

(1952-1957)

\begin{tabular}{|l|c|c|}
\hline \multicolumn{1}{|c|}{ Empresas } & $\begin{array}{c}\text { Investimentos } \\
\text { (Cr\$ milhões) }\end{array}$ & $\begin{array}{c}\text { Acréscimo de } \\
\text { Capacidade Geradora (MW) }\end{array}$ \\
\hline Públicas $\left(^{*}\right)$ & 4.240 & 331,2 \\
Grupo Light & 696 & 160,0 \\
Grupo Amforp & 2.179 & 170,6 \\
Independentes $(* *)$ & 114 & 21,1 \\
\hline T O T A L & $\mathbf{7 . 2 2 9}$ & $\mathbf{6 8 2 , 9}$ \\
\hline
\end{tabular}

Obs.: $\left(^{*}\right)$ Empresas Públicas: Chesf, CEEE (RS), Cemig (MG) e Uselpa (SP).

$(* *)$ Empresas Independentes: Companhia Nacional de Energia Elétrica e Companhia Matogrossense de Eletricidade

Fonte: Extraído de Lima (1995, p. 60), elaborada a partir do Relatório Geral da Comissão Mista Brasil - Estado Unidos para o Desenvolvimento Econômico.

Percebe-se, claramente que, embora a orientação da CMBEU delegasse ao Estado a função "reguladora e supletiva", as empresas públicas acabaram, no período, assumindo um papel de destaque na expansão da capacidade de geração, respondendo por quase 48,5\%.

Apesar deste incremento, a seca verificada entre os anos de 1952-1954 revelou a necessidade de ampliar os investimentos na área energética. Além disso, após a aprovação do projeto pelo Congresso Nacional, que criou a Petrobrás e instituiu o monopólio estatal do petróleo, o governo norte-americano decidiu suspender as atividades da CMBEU, rompendo as negociações com o Brasil, em 1953, o que veio a comprometer ainda mais a expansão do setor elétrico. É oportuno lembrar, que:

“do ponto de vista do financiamento externo, o saldo dos trabalhos desenvolvidos 
pela CMBEU foi um aporte de recursos da ordem de US\$102,2 milhões do Banco Mundial e do Eximbank (78,8\% do montante previsto em moeda estrangeira), que beneficiou as concessionárias estrangeiras e parcela das empresas estaduais" ${ }^{\prime 30}$.

Tentando equacionar este impasse, o governo federal enviou ao Congresso, em maio de 1953, o Projeto de Lei 3.204/53, elaborado com a finalidade de regulamentar o Imposto Único sobre Energia Elétrica - IUEE, previsto na Constituição de 1946, e instituir o Fundo Federal de Eletrificação - FFE.

Esse projeto de lei, que foi transformado na Lei 2.308/54, em 31 de agosto de 1954, poucos dias após o suicídio de Getúlio Vargas, estabeleceu que o IUEE fosse cobrado pela União sob a forma de imposto sobre consumo, sendo $40 \%$ de sua arrecadação destinada à União e 60\% repartido entre Estado, Distrito Federal e Municípios.

O FFE, por sua vez, estava destinado, como aponta Lima (1984, p. 75), “não apenas a financiar os investimentos do setor elétrico como também visava ao desenvolvimento da indústria de material elétrico pesado". Sua constituição, conforme descreve o autor, seria composta pela parcela do imposto único pertencente à União, por $20 \%$ da arrecadação da taxa de despacho aduaneiro e pelas dotações do orçamento geral da União, ficando consignada por 10 anos uma parcela, nunca inferior a $4 \%$ da arrecadação do imposto sobre consumo, exclusivamente para esse fundo.

Neste novo arranjo, o BNDE tornou-se o receptor legal de toda a arrecadação do IEE, com a tarefa adicional de gerenciar o FFE, administrando, inclusive, a parcela do IUEE pertencente à União, bem como a sua repartição entre estados e municípios ${ }^{31}$. Além disso, deveria atuar como banco de fomento dos investimentos setoriais em relação às concessionárias.

Como se pode verificar, através de uma saída fiscal, o Executivo buscou criar as condições efetivas para a realização dos investimentos no setor elétrico. Cumpre lembrar, contudo, que esta iniciativa não suspendeu a vigência de tributos semelhantes, estabelecidos pelos Estados e Municípios, que já contavam com taxas de eletrificação

\footnotetext{
${ }^{30}$ Lima (1995, p. 61).

${ }^{31}$ Destaque-se que o projeto de lei, que tratava dos critérios para a distribuição de tais recursos, entre as diferentes esferas da federação, encaminhado ao Congresso Nacional em agosto de 1953, demorou três anos para ser aprovado, em razão de disputas regionais.
} 
vinculada a projetos regionais.

Completando a proposta anterior, a próxima etapa concentrou-se na definição de um programa de investimento, com a montagem de um modelo institucional, nas linhas estabelecidas no Plano Nacional de Eletrificação - PNE, defendido pelo Presidente Getúlio Vargas, que partia da seguinte lógica ${ }^{32}$ :

a) os empreendimentos industriais previstos para serem executados pela União, compreenderiam somente grandes usinas geradoras e linhas transmissoras em alta tensão, além de a implantação da indústria pesada de material elétrico, caso a iniciativa privada não tenha interesse em criar; e

b) a distribuição de energia aos mercados consumidores seria de responsabilidade da iniciativa privada e dos governos regionais e locais, mesmo nas zonas a serem supridas preponderantemente pelas usinas federais.

Além disso, durante o segundo Governo Vargas, foi vislumbrada a criação das Centrais Elétricas Brasileiras S.A.- Eletrobrás, que seguiria a mesma organização lógica do projeto Petrobrás, visando, com isso, garantir o arcabouço institucional para os empreendimentos encaminhados pelo governo federal no setor elétrico. Além disso, de acordo com a observação de Lima (1995), ao assumir o papel de holding das empresas federais integrantes do PNE, a Eletrobrás promoveria, também, a articulação em torno da constituição da indústria de material elétrico pesado no país, associada ou não ao capital privado, nacional ou estrangeiro.

Assim, evidencia-se durante o segundo governo Vargas, sua preocupação com relação à questão do desenvolvimento do setor elétrico brasileiro. De um lado, vários projetos na área elétrica foram estimulados, deixando clara a necessidade de intervenções públicas diretas, supletivas à iniciativa privada, em resposta, inclusive, às restrições de participação do capital externo. E de outro, a reorganização institucional da infra-estrutura produtiva do setor foi desenhada neste momento particular da história brasileira, deixando a tarefa de sua implementação, para os governos subseqüentes.

$\mathrm{Na}$ verdade, muitos autores entendem que o Presidente Getúlio Vargas tentou

\footnotetext{
${ }^{32}$ Lima (1995, p.65).
} 
implantar no Brasil, em especial no período 1953/1954, um “projeto de desenvolvimento capitalista nacional", chegando até mesmo a receber a denominação de nacional-reformista, ao posicionar-se entre dois extremos: de um lado, pressionando os representantes do capital “imperialista" e, de outro, negociando com eles ${ }^{33}$.

De qualquer modo, o fato é que nesta fase do movimento de industrialização brasileira, as medidas de política econômica adotadas, particularmente àquelas relativas à infra-estrutura nacional, refletiram a preocupação do governo central em definir, claramente, a responsabilidade e o papel a ser assumido por cada um dos agentes envolvidos no processo, bem como criar formas internas de financiamento, capazes de viabilizar o desenvolvimento econômico brasileiro de maneira mais autônoma, fundando as bases para uma expansão industrial mais equilibrada.

Entretanto, com o suicídio do Presidente Getúlio Vargas, em agosto de 1954, há o entendimento de que este projeto nacional acabou sendo substituído, com a implantação de um sistema orientado para o desenvolvimento econômico dependente dos países centrais. $\mathrm{Na}$ verdade, após uma fase de transição marcada, no plano interno, pela instabilidade do quadro político-institucional, e, no internacional, pela reacomodação das grandes potências Pós-Guerra da Coréia, verifica-se uma tendência de acentuada expansão do capitalismo internacional no sentido centro-periferia, nos termos destacados no Capítulo 1.

Para o caso brasileiro, essa orientação foi reforçada com a implantação da Instrução 113 da Sumoc - Superintendência da Moeda e do Crédito, no início de 1955, que definiu uma série de incentivos à entrada de investimentos estrangeiros diretos no Brasil ${ }^{34}$. Conforme esclarece Baer (1996, p. 72), em meados da década de 50,

"os formuladores da política econômica brasileiros estavam convencidos de que somente poderia obter índices elevados de crescimento econômico e modernização através de mudanças estruturais ocasionadas pela industrialização".

Para atingir este objetivo, a presença do capital externo foi entendida como fundamental, encontrando na política cambial, uma forte aliada. Isto porque, naquele momento, usando as palavras de Oreinstein e Sochaczewski (1990, p. 171), “política

\footnotetext{
${ }^{33}$ Para uma análise mais detalhada desse debate ler Ianni (1991).

${ }^{34}$ No texto, Baer (1996) descreve com detalhes os mecanismos ligados à Instrução 113, da Sumoc.
} 
cambial constituiu-se no principal, senão o único, instrumento de política econômica à disposição do setor público", para atrair tais recursos. Assim, as manipulações na taxa de câmbio e a imposição de quotas, tarifas e impostos de importação e exportação, formavam o conjunto principal de estratégias operacionais dos gestores da política econômica.

É com esta perspectiva, que, em fins de 1956, o então Presidente Juscelino Kubitschek (J.K.) apresentou seu conhecido "Plano de Metas", que de acordo com Lessa (1981, p. 27),

"constitui a mais sólida decisão consciente em prol da industrialização na história econômica do país, .... conferindo prioridade absoluta à construção dos estágios superiores da pirâmide industrial verticalmente integrada e do capital social básico de apoio a esta estrutura. Isto, .......daria continuidade ao processo de substituição de importações que se vinha desenrolando nos dois decênios anteriores".

Dessa forma, valendo-se de diagnóstico semelhante aos levantados nos estudos realizados pelo Grupo Misto Cepal-BNDE, em 1955, incorporando as contribuições da Comissão Mista Brasil-Estados Unidos e da Assessoria Econômica do Governo Vargas, o programa contemplava, principalmente, as áreas de infra-estrutura (energia e transportes), responsáveis por $73 \%$ do investimento global estimado pelo plano, seguido por $20,4 \%$ sinalizado para a indústria de base e $6,6 \%$ para alimentação e educação ${ }^{35}$.

$\mathrm{Na}$ verdade, o setor energético, isoladamente, constituiria a principal prioridade dos investimentos previstos, ao cobrir $43,4 \%$ do total estimado. As principais metas estabelecidas para o setor, como bem sistematizaram Lessa (1983, p. 37) e Lafer (1970, p. 43), foram:

a) energia nuclear: nesta área destaca-se a prioridade na formação técnica de pessoal necessário à execução do programa nacional de energia nuclear; fabricação nacional de combustível nuclear, planejamento de instalações de usinas termelétricas, produção e distribuição de rádio-isótopos.

b) carvão mineral: meta inicial, elevação da produção de carvão mineral para 2.500.000 t, em 1960, meta revista, 3.000.000 t para 1960. Na verdade, o plano

\footnotetext{
${ }^{35}$ Dados extraídos de Lessa (1983), citando VI Exposição do Programa de Reaparelhamento Econômico BNDE.
} 
propunha uma modificação estrutural na indústria carvoeira em crise devido à dieselização da rede ferroviária, que deixou sem procura os tipos inferiores de carvão, de produção obrigatória. Assim, durante a realização do Plano de Metas lançaram-se as bases para a modificação da composição interna da procura de carvão, através do início da construção de usinas termelétricas à boca de minas.

c) petróleo: meta de produção interna para $100.000 \mathrm{bb} / \mathrm{d}$ e ampliação da capacidade de refino para $308.000 \mathrm{bb} / \mathrm{d}$, para 1960 . Tais metas refletem a política petrolífera estabelecida, a partir da criação da Petrobrás, em 1954, ou seja, de um lado, perseguir a substituição integral das importações de combustíveis líquidos, através da instalação de um parque refinador, e, de outro, ampliar a produção nacional de petróleo, com a implantação de um programa de prospecções.

d) energia elétrica: fazia-se necessário prever a manutenção de uma taxa de crescimento anual de produção de energia elétrica, de maneira a dar suporte à contínua expansão industrial, em pelo menos 10\% a.a.. Para tal, foi dimensionada a meta de ampliação da capacidade instalada de energia elétrica de $3.491 \mathrm{MW}$, em 1956, para 5.194 MW, em 1960, e 8.255 MW, em 1965, totalizando um acréscimo de potência instalada de energia elétrica da ordem de 4.764 MW.

Cumpre ressaltar, entretanto, que as obras previstas, referentes a este acréscimo de potência, a ser atingido entre 1956 e 1965, foram classificadas em três grupos, conforme destaca Lima (1984, p. 97), a saber: "grupo A, obras já planificadas e com orçamento definido; grupo B, obras já estudadas, mas sem orçamento realizado; e grupo $\mathrm{C}$, obras necessárias ao programa, mas ainda não estudadas".

A Tabela 2.7. tenta demonstrar a participação de cada grupo de obras. A partir de seus dados, verifica-se que $55,2 \%$ da previsão de expansão da capacidade instalada, excluindo as obras previstas pelo Grupo $\mathrm{C}$, caberiam às concessionárias públicas (federais $\mathrm{e}$ estaduais). Tal comportamento é resultado das próprias características que envolveriam os projetos do setor, centrados na construção de usinas hidrelétricas de grande porte, com elevada relação produto/capital. Desta forma, os vultosos recursos exigidos, os longos períodos de maturação e a baixa rentabilidade levaram à ampliação da importância do setor 
público como produtor no setor energético.

Tabela 2.7

Plano de Metas

Previsão de acréscimo de potência instalada de energia elétrica, por grupos de obras

\begin{tabular}{|l|c|c|}
\hline \multicolumn{1}{|c|}{ Grupos de Obras } & $\begin{array}{c}\text { (1957-1965) } \\
\text { Acréscimo de } \\
\text { Potência (MW) }\end{array}$ & $\begin{array}{c}\text { Participação relativa } \\
\mathbf{( \% )}\end{array}$ \\
\hline Grupo A & $\mathbf{3 . 2 0 2}$ & $\mathbf{6 7 , 2}$ \\
- Concessionárias Privadas & 941 & 19,8 \\
- Concessionárias Públicas Federais & 1.220 & 25,6 \\
- Concessionárias Públicas Estaduais & 1.041 & 21,8 \\
Grupo B & $\mathbf{4 6 2}$ & $\mathbf{9 , 7}$ \\
- Concessionárias Privadas & 90 & 1,9 \\
- Concessionárias Públicas Federais & 246 & 5,2 \\
- Concessionárias Públicas Estaduais & 126 & 2,6 \\
Grupo C & $\mathbf{1 . 1 0 0}$ & $\mathbf{2 3 , 1}$ \\
\hline Total & $\mathbf{4 . 7 6 4}$ & $\mathbf{1 0 0 , 0}$ \\
\hline
\end{tabular}

Fonte: Extraído de Lima (1984, p. 97), elaborada a partir da Presidência da República, Conselho de Desenvolvimento. Plano de Desenvolvimento Econômico, 1957.

De qualquer modo, é bom destacar que, embora a previsão fosse atingir cerca de 2.000 MW adicionais na capacidade instalada em energia elétrica, entre 1957-1961, os dados da Tabela 2.8. apontam para um incremento de 1.655,2 MW, representando $83 \%$ da meta estimada para o setor e um aumento de 46,6\% em relação a 1956.

Além disso, tem-se uma expressiva presença das concessionárias públicas no efetivo crescimento verificado na capacidade instalada de geração de eletricidade, no referido período. No total de energia gerada, a participação das concessionárias públicas passou de $6,8 \%$, em 1952, para 25,8\%, em 1961, representando um aumento de cerca de $890 \%$ em termos de MW gerados, contra $98 \%$ da ampliação privada ocorrida no mesmo período. $\mathrm{Na}$ verdade, a partir do Plano de Metas e com a posterior aprovação da holding Eletrobrás, a seguir explicita, foi se consolidando a participação das concessionárias públicas, que ao final de 1965 já eram responsáveis por quase 55\% do total de energia elétrica gerada no país. 
Tabela 2.8.

A evolução da capacidade instalada de energia elétrica por categoria de concessionário (1952-1965)

\begin{tabular}{|l|l|l|l|l|l|l|l|l|}
\hline Anos & $\begin{array}{c}\text { Público } \\
\text { MW }\end{array}$ & \multicolumn{1}{|c|}{} & $\begin{array}{c}\text { Privado } \\
\mathbf{M W}\end{array}$ & $\begin{array}{c}\text { \% } \\
\text { Autoprodutor } \\
\text { MW }\end{array}$ & $\begin{array}{c}\text { \% } \\
\text { MWtal }\end{array}$ & \% \\
\hline 1952 & 135,6 & 6,8 & $1.635,5$ & 82,4 & 213,7 & 10,8 & $1.985,00$ & 100,00 \\
\hline 1953 & 171,1 & 8,1 & $1.631,3$ & 77,5 & 302,5 & 14,4 & $2.089,9$ & 100,00 \\
\hline 1954 & 303,2 & 10,8 & $2.159,6$ & 77,0 & 342,7 & 12,2 & $2.805,5$ & 100,00 \\
\hline 1955 & 538,5 & 17,1 & $2.248,4$ & 71,4 & 361,6 & 11,5 & $3.148,5$ & 100,00 \\
\hline 1956 & 657,1 & 18,5 & $2.551,9$ & 71,9 & 341,0 & 9,6 & $3.550,0$ & 100,00 \\
\hline 1957 & 681,0 & 18,1 & $2.696,2$ & 71,6 & 390,2 & 10,3 & $3.767,4$ & 100,00 \\
\hline 1958 & 824,5 & 20,6 & $2.742,8$ & 68,7 & 425,8 & 10,7 & $3.993,1$ & 100,00 \\
\hline 1959 & 968,5 & 23,5 & $2.724,0$ & 66,2 & 422,7 & 10,3 & $4.115,2$ & 100,00 \\
\hline 1960 & $1.098,9$ & 22,9 & $3.182,2$ & 66,3 & 519,0 & 10,8 & $4.800,1$ & 100,00 \\
\hline 1961 & $1.341,5$ & 25,8 & $3.242,1$ & 62,3 & 621,6 & 11,9 & $5.205,2$ & 100,00 \\
\hline 1962 & $1.791,9$ & 31,3 & $3.161,4$ & 55,2 & 775,5 & 13,5 & $5.728,8$ & 100,00 \\
\hline 1963 & $2.305,5$ & 36,3 & $3.164,4$ & 49,8 & 885,5 & 13,9 & $6.355,1$ & 100,00 \\
\hline 1964 & $2.872,4$ & 42,0 & $3.084,7$ & 45,1 & 882,9 & 12,9 & $6.840,0$ & 100,00 \\
\hline 1965 & $4.048,0$ & 54,6 & $2.486,2$ & 33,6 & 876,8 & 11,8 & $7.411,0$ & 100,00 \\
\hline
\end{tabular}

Fonte: Lima, J.L. Estado e energia elétrica no Brasil: o setor elétrico no Brasil, das origens à criação da Eletrobrás (1890-1962), p. 109.

Quanto às fontes de recursos previstas, para viabilizar o financiamento da ampliação do setor, o governo federal previa que $68,3 \%$ seriam provenientes de recursos de natureza fiscal vindos da União e dos Estados ${ }^{36}$. Como sempre, a parcela em descoberto, isto é, $31,7 \%$ poderiam ser assegurados com recursos provenientes da iniciativa privada, desde que estes investidores se sentissem atraídos pela legislação tarifária.

Registre-se, ainda, que dada à demora na aprovação do projeto que criaria a Eletrobrás, em tramitação no Congresso Nacional, o governo J.K. acabou por exigir do BNDE que assumisse a função estratégia de coordenar os investimentos públicos na área de energia e a coordenação da distribuição dos recursos do IUEE destinados a Estados e municípios $^{37}$. Com isso, o BNDE firmou-se como agência pública de financiamento do

\footnotetext{
${ }^{36}$ Conforme coloca Lima (1995, p. 71), “dos recursos provenientes da União, 65\% adviriam do Fundo Federal de Eletrificação e o restante de dotações alocadas a programas regionais de desenvolvimento. Do ponto de vista da participação estadual, destacava-se a receita proporcionada pelas taxas estaduais de eletrificação ( $80 \%$ dos recursos estaduais), em montante bem superior às estimativas de arrecadação do IUEE por parte de estados e municípios".

${ }^{37}$ Cumpre lembrar que o BNDE, conforme visto, já tinha a atribuição de administrar o FFE, sendo que para o IUEE, os critérios de repartição desta receita foram assim estabelecidos, segundo o decreto 40.007/56: 40\% destinavam-se à União; 50\% aos Estados e Distrito Federal; e 10\% aos municípios.
} 
setor de energia elétrica, incorporando, inclusive, as iniciativas estaduais ao programa de energia elétrica do Plano de Metas $^{38}$. A Tabela 2.9. explicita a participação do banco nos recursos totais do setor, registrando-se que, em 1962, foi responsável por $84 \%$ do incremento da capacidade instalada de energia elétrica daquele ano no país.

Tabela 2.9.

Participação do BNDE na expansão da capacidade instalada de energia elétrica (1954-1962)

\begin{tabular}{|l|c|c|c|c|}
\hline Anos & & \multicolumn{2}{|c|}{ Capacidade Instalada (MW) } & \\
\hline & Total & $\begin{array}{c}\text { Crescimento Anual } \\
\text { (a) }\end{array}$ & $\begin{array}{c}\text { Financiamento BNDE } \\
\text { (b) }\end{array}$ & $\begin{array}{c}\text { b/a } \\
\text { (\%) }\end{array}$ \\
\hline 1954 & $2.805,5$ & - & - & - \\
\hline 1955 & $3.148,5$ & 340,9 & 31,6 & 9,3 \\
\hline 1956 & $3.550,0$ & 401,5 & 54,1 & 13,5 \\
\hline 1957 & $3.767,4$ & 217,4 & 102,0 & 46,9 \\
\hline 1958 & $3.993,1$ & 225,7 & 81,7 & 36,2 \\
\hline 1959 & $4.115,2$ & 122,1 & 72,5 & 59,4 \\
\hline 1960 & $4.800,1$ & 684,9 & 513,3 & 74,9 \\
\hline 1961 & $5.205,2$ & 405,1 & 126,4 & 31,2 \\
\hline 1962 & $5.728,8$ & 523,6 & 440,0 & 84,0 \\
\hline $1954-62$ & & $2.921,2$ & $1.421,6$ & 48,7 \\
\hline
\end{tabular}

Fonte: IESP/Fundap (1989), Financiamento das Empresas Estatais - Volume 2, Relatórios de Pesquisa, 8, São Paulo, p. 143.

Com esse conjunto de informações, percebe-se, claramente, o avanço dos investimentos do setor elétrico, ao longo da gestão J.K. Entretanto, do ponto de vista institucional, poucas mudanças foram efetivadas. Neste particular, merece atenção especial à resistência interna, dos próprios responsáveis pelo programa de energia elétrica do Plano de Metas, em agilizar a aprovação no Congresso Nacional, de dois projetos encaminhados durante o segundo governo Vargas, vale lembrar: a implantação do Plano Nacional de Eletrificação - PNE e a criação da Eletrobrás.

$\mathrm{Na}$ verdade, essa postura expressa as divergências existentes entre as duas gestões com relação ao papel e a forma de intervenção do Estado no setor elétrico brasileiro. Isto porque, ao permitir a aprovação do PNE, o governo J.K. temia que o Fundo Federal de Eletrificação fosse utilizado de maneira equivocada, pulverizados em projetos políticopartidários, sem nenhuma lógica financeira ou setorial, o que poderia comprometer o

\footnotetext{
${ }^{38}$ Uma análise detalhada da atuação do BNDE e das Empresas Públicas Estaduais na expansão do setor elétrico pode ser encontrada em Lima (1984).
} 
desenvolvimento do setor. Além disso, discordava da análise delineada no PNE de que a indústria de material elétrico deveria ser estatizada, por entender tratar-se de segmento industrial periférico, não cabendo ao Estado atuar.

Tais ponderações, no fundo, revelam o grau de envolvimento do governo J.K. com a inserção brasileira no cenário internacional, que acenava com a perspectiva de expansão das empresas multinacionais em direção às economias de industrialização tardia, abrindo horizontes extremamente favoráveis de negociação e atração de investimentos diretos em indústrias de bens de consumo e de bens de produção.

Quanto à constituição da holding federal Eletrobrás, além de ter enfrentado oposição dos setores estrangeiros no Brasil e da mídia que os representava, de fato, a maior resistência estava ligada às divergências de interesses entre as empresas federais e os grupos estaduais em relação às prioridades de intervenção estatal no setor de energia elétrica. Esse ponto, entretanto, foi aos poucos sendo superado, tendo em vista os seguintes motivos, levantados por Lima (1995. p.76):

a) a regulamentação integral do Código de Águas, através do Decreto 41.091/57, que ao manter o regime de remuneração garantida, trouxe maior flexibilidade para as empresas concessionárias na adoção dos reajustes tarifários ${ }^{39}$;

b) a criação do Ministério das Minas e Energia, incorporando o Conselho Nacional de Águas e a Divisão de Águas, do Ministério da Agricultura, e as empresas federais de energia elétrica, pela Lei 3.782/60;

\footnotetext{
39 Conforme explicado por Lima (1996, p. 150), essa medida, abolida apenas em 1993, permitia que a concessionária, por lei, tivesse "o direito a uma remuneração mínima de $10 \%$ e máxima de $12 \%$ sobre o capital investido (ativo imobilizado em serviço). Como a taxa de retorno sobre o capital é, por definição, um dado sobre o qual o investidor não tem controle direto, pois é definido ex post, a partir da comparação entre lucros obtidos e capital investido (receita-despesa/capital investido), a legislação do setor estabelecia que as diferenças negativas ou positivas entre a remuneração efetiva do concessionário e a garantida por lei seriam depositadas (sendo maior) ou registradas (sendo menor) na Conta de Resultados a Compensar (CRC). Na prática, a CRC constituía um crédito das concessionárias contra a União, como se o poder concedente, por qualquer razão, não tivesse conseguido estabelecer um nível tarifário suficiente para garantir o equilíbrio econômico-financeiro das concessionárias". Além disso, o autor esclarece ainda que, "o DNAEE estabelecia os reajustes tarifários com base nos cálculos específicos realizados para cada empresa, a partir da análise dos custos incorridos por nível de tensão. Dessa forma, esse sistema garantia a independência de cada unidade empresarial perante as demais, uma vez que as negociações com o DNAEE envolviam apenas a aplicação da rentabilidade legal sobre os componentes do custo do serviço".
} 
c) as dificuldades, por parte do BNDE, de coordenar os investimentos nessa área, dada à complexidade do setor e aos limites de sua capacidade de garantir a ampliação de investimentos; e

d) a tramitação no Senado, em 1957, do projeto da criação da Eletrobrás, permitiu alterações no texto original, em especial no que se refere à imposição de limitações às atribuições da holding, particularmente em relação aos seus vínculos com a indústria de material elétrico pesado.

Além disso, como ressalta Lima (1995, p.80-81),

"com o êxito alcançado pela intervenção estatal na expansão do setor de energia elétrica e a decorrente consolidação da empresa pública, de âmbito estadual e federal, amadurecem as condições de autonomização institucional do setor energético na órbita da administração pública."

Assim, após ampla discussão, em 1961, o Congresso Nacional aprovou a criação da Eletrobrás, através da Lei 3.890-A, que estabeleceu como seus objetivos a realização de estudos, projetos, construção e operação de usinas produtoras, linhas de transmissão e distribuição de energia elétrica, marcando o início de um novo ciclo para o setor, ao buscar ampliar a capacidade instalada de energia elétrica no país, com a ativa participação do Estado.

Com essa medida, a Eletrobrás passaria a assumir o papel, até então, desempenhado pelo BNDE, de entidade federal de planejamento do setor, administrando tanto o Fundo Federal de Eletrificação - FFE, como todas as participações da União nas empresas de energia, isto é, a carteira das aplicações efetuadas junto às concessionárias.

Ressalte-se, entretanto, que, apesar de tal feito ter ocorrido em 1961, sua instalação oficial aconteceu, de fato, em junho de 1962, atravessando, portanto, quatro mandatos presidenciais, uma vez que, em 1954, conforme visto, o projeto de criação da Eletrobrás foi enviado pelo presidente Getúlio Vargas ao Congresso, tramitou até o fim do governo Juscelino Kubitschek, passou por Jânio Quadros e foi, finalmente, concretizado no governo de João Goulart.

Em paralelo, com a finalidade de atender, particularmente, a reconstituição das 
bases de financiamento do setor público, afetadas pela persistência do processo inflacionário ${ }^{40}$, e de reforçar o papel de holding financeira da Eletrobrás, duas medidas foram lançadas à época.

A primeira foi a promulgação da Lei 4.156/62, que transformou o IUEE em tributo ad valorem e criou o Empréstimo Compulsório - EC, originalmente pelo prazo de cinco anos, ampliando, desta maneira, as fontes de financiamento do setor. Cumpre lembrar que os recursos provenientes do EC seriam apropriados pela Eletrobrás e reinvestidos nos setor, de acordo com uma política setorial e regional, sendo que, de início, $60 \%$ desses recursos deveriam ser reaplicados nos estados, proporcionalmente à arrecadação de cada um deles ${ }^{41}$. A segunda, representando uma contrapartida ao empréstimo compulsório, calculado como percentagem do valor da conta, eram obrigações da Eletrobrás, com rendimento de $12 \%$ a.a. e prazo de resgate de dez anos.

Ao estabelecer este conjunto de medidas, o governo federal completou o grande ciclo de mudanças, onde a ação do Estado foi decisiva para consolidar o desenho institucional do setor. Neste processo, percebe-se um gradual afastamento e substituição do capital privado estrangeiro no setor, dominante no início do século XX, por um arranjo que buscava integrar as empresas federais e as concessionárias estaduais, dado o peso das empresas públicas na área de energia elétrica brasileira, conforme foi explicitado na Tabela 2.8 .

Em paralelo, o Plano de Metas permitiu a entrada do capital privado externo em diversas áreas da atividade econômica nacional, o que criou as condições concretas para o avanço da consolidação de um parque produtivo, capaz de impulsionar a economia brasileira até, pelo menos, meados da década de 70 .

Finalizando, é oportuno registrar que, entre os anos de 1963-1965, o Presidente João Goulart, que assumiu o cargo após a renúncia de Jânio Quadros, em agosto de 1961, tentou implementar o Plano Trienal, formulado por Celso Furtado, Ministro do Planejamento, e San Tiago Dantas, Ministro da Fazenda. O plano pretendia atingir os seguintes objetivos: a)

\footnotetext{
${ }^{40}$ Apenas para ilustrar, tem-se que, em 1961, a taxa de inflação foi de 33,2\%, enquanto em 1962, alcançou 45,5\%.

41 Rodrigues e Dias (1994, p. 63-64) lembram, ainda, que o empréstimo compulsório foi estendido de 1968 até 1973 e, posteriormente, até 1983.
} 
controlar de forma progressiva o processo inflacionário; b) permitir a recuperação do ritmo do desenvolvimento observado no período 1957-1961, em torno de 7\% a.a.; c) viabilizar algumas correções de distribuição de renda quer sob o aspecto pessoal quer sob o aspecto regional; d) realizar reformas de base nas áreas administrativa, bancária, fiscal e agrária; e e) reescalonar a dívida externa.

Infelizmente, embora o referido plano tenha procurado alcançar um conjunto de objetivos que, de um modo geral, eram bastante pertinentes aos problemas enfrentados pelo País na época, seus avanços foram mínimos. Na verdade, como aponta Lacerda (2002, p. 102), "a tentativa de estabilização fracassou e provocou o crescimento negativo do PIB per capita; a economia cresceu 6,6\% em 1962, mas apenas 0,6\% em 1963, com inflação anual de 83,25\%". Assim, em julho de 1963, o Ministro Furtado deixa sua pasta e, a partir de então, se acirram os conflitos sociais e políticos, acentuando o movimento de desestabilização interna e externa, levando ao fim o governo com o golpe militar de 1964.

\subsection{O desenvolvimento do setor de energia elétrica e as reformas do período 1964/79}

Como sintetiza Lacerda (2002, p. 103/104),

"O regime militar assumiu a direção do país, em 1964, com uma postura tecnocrático-modernizante, comprometido com a superação das políticas populistas de João Goulart, consideradas atrasadas e ultrapassadas. Apesar das críticas ao nacionalismo econômico do governo deposto, o novo regime manteria um discurso desenvolvimentista comprometido com a retomada do crescimento econômico. A prioridade inicial do novo governo foi a normalização das relações com os organismo financeiros internacionais..... O Brasil assumiu então uma clara subordinação: tratava-se do aprofundamento do modelo de capitalismo dependente e associado, já hegemônico no país desde o Plano de Metas de JK. O resultado foi o aumento da internacionalização da economia brasileira com relação aos capitais externos e a consolidação da oligopolização, com o franco predomínio das EMN"42.

Com essa perspectiva, o Plano de Ação Econômica do Governo - PAEG (1964/66), elaborado por Roberto Campos, que assumiu o comando do recém-criado Ministério do Planejamento e da Coordenação Econômica, e por Otávio Bulhões, Ministro da Fazenda, centrou-se em dois objetivos básicos: a) reverter à tendência inflacionária, verificada a partir de 1959; e b) superar o movimento de estagnação econômica, em curso desde 1962.

\footnotetext{
${ }^{42}$ EMN é a sigla usada para a denominação de Empresas Multinacionais.
} 
Além disso, as autoridades econômicas pretendiam, também, atenuar os desníveis econômicos setoriais e regionais, assegurar o crescimento na taxa de oferta de empregos, em decorrência de uma ampla política de investimentos, e, por fim, corrigir a tendência a déficits do balanço de pagamentos, que trazia restrições à capacidade de importar brasileira. Essas últimas preocupações alinhavam-se, perfeitamente, com o discurso desenvolvimentista do período anterior, em muito se assemelhando às metas defendidas no próprio corpo do Plano Trienal.

Assim, conforme ressalta Martone (1970, p. 77), toda a estratégia de combate à inflação, posta em prática pelo PAEG,

"assenta-se no objetivo de cortar toda demanda que excedesse o nível de pleno emprego, na tentativa de manter o equilíbrio do sistema com plena utilização dos fatores de produção. Para tanto, era necessário tornar compatíveis três políticas: a) a política de crédito ao governo; b) a política de crédito ao setor privado; e c) a política salarial”.

Em um ambiente extremamente autoritário, marca dos regimes militares, foi possível implementar uma dura política de contenção salarial, ações de controle das contas públicas, com cortes nas despesas e aumento das receitas, por meio de reforma tributária e dos aumentos das tarifas públicas (a chamada "inflação corretiva"), e a execução de uma política monetária restritiva, com controle de emissão de moeda e de crédito. Com tais medidas, as taxas de inflação reduziram-se, entre os anos de 1964 e 1968, da casa dos 90\% a.a. para os $20 \%$ a.a.

Em contrapartida, uma série de transformações institucionais, com destaque para a reforma monetária/financeira, tributária e de política externa ${ }^{43}$, foi imposta ao País, visando incrementar a poupança interna, recuperar os investimentos internos e atrair o capital estrangeiro.

Dentre as medidas que permitiram a retomada dos investimentos públicos, particularmente nas áreas de infra-estrutura e de insumos básicos, que sofreram algumas interrupções em decorrência da fase de instabilidade político-institucional anterior a 1964, e viabilizar a expansão das empresas integrantes do Setor Produtivo Estatal, garantindo-lhes

\footnotetext{
${ }^{43}$ Gremaud et alii (2005, p. 395-401) faz uma excelente síntese das principais mudanças institucionais implantadas durante o PAEG.
} 
maior autonomia financeira, destacam-se:

a) verdade tarifária: implementada com o propósito de elevar e reestruturar os preços dos serviços públicos, permitindo, assim, a ampliação da capacidade de autofinanciamento das empresas e a redução da necessidade de subsídios por parte do governo;

b) instituição da correção monetária: representou um elemento adicional na reconstituição da capacidade de investimento do setor, pois, além de corrigir o valor do serviço prestado, amenizaria a pressão das empresas públicas sobre o Tesouro Nacional; e

c) reforma fiscal: orientada para melhorar as condições de financiamento do gasto público corrente, através, não apenas do aumento de receitas (com a criação de novos impostos) e redução de despesas, mas, também pela redefinição do espaço tributário entre as diversas esferas de governo.

É neste ambiente que deve ser analisado o desenvolvimento do setor de energia elétrica, tanto do ponto de vista institucional como físico. Isto porque, pós-1964, verificase, de um lado, a consolidação e a expansão da Eletrobrás, como agência de planejamento setorial e holding das empresas federais, e de outro, o fortalecimento das empresas coligadas, em suas respectivas áreas de concessão.

Esse comportamento é resultado da própria ação do governo que, durante este período, além de ter dado continuidade a diversos projetos de infra-estrutura ${ }^{44}$, processou a reestruturação dos órgãos da administração direta, voltados para funções normativas de diversos setores. No caso específico da área de energia, como bem resgatou Lima (1995, pp. 99-100), a partir de 1969, foi consolidada a estrutura básica da administração federal dos serviços de eletricidade, que se manteve até a reestruturação do setor elétrico, ocorrida em meados da década de noventa, conforme será visto no próximo capítulo. Assim de forma sintetizada, dois grandes agentes federais saem fortalecidos deste processo:

\footnotetext{
${ }^{44}$ Ressalte-se que os setores de energia e transportes foram responsáveis por montante superior a $55 \%$ dos investimentos previstos pela programação para o setor produtivo estatal, sendo que os investimentos em energia detinham, isoladamente, a maior participação relativa, quase $20 \%$ da previsão global, ver Lima (1995, p. 95).
} 
a) Departamento Nacional de Águas e Energia Elétrica - DNAEE: assume todas as funções inerentes ao poder concedente, transformando-se, portanto, em órgão normativo e fiscalizador do setor de energia elétrica. Dentre suas atribuições, destacam-se: promover atos normativos pertinentes à prestação de serviços de eletricidade; responder pela concessão de aproveitamento de recursos hídricos; fixar as tarifas de energia elétrica e atuar como árbitro das pendências suscitadas pela aplicação da legislação.

b) Eletrobrás: responsável pela execução das funções de coordenação e planejamento da expansão e operação do sistema elétrico, da gestão financeira e empresarial e a articulação do setor com a indústria. Em suma, torna-se responsável pela execução da política federal de energia elétrica.

Com essa divisão de tarefas, acaba saindo fortalecida a holding federal Eletrobrás, refletindo uma das características centrais de regimes autoritários: a concentração do poder nas mãos do governo federal em detrimento dos estados e municípios.

Do ponto de vista do financiamento do setor, três observações revelam o impacto das mudanças citadas anteriormente sobre suas principais fontes, quais sejam:

a) instituição da correção monetária: Essa medida, conforme destacado anteriormente, produziu um impacto imediato sobre as tarifas de serviços de energia elétrica, contribuindo para a reconstituição da capacidade de autofinanciamento do setor de energia elétrica, representando, portanto, no principal instrumento da política de "realismo tarifário" implantada no período. Além disso, a correção monetária dos ativos vinculados ao serviço público, associada à aplicação da taxa de remuneração, de no mínimo 10\% sobre o capital investido, como destacado por Lima (1995, p. 101), "elevariam, de um lado, o custo do serviço prestado e, de outro, as margens de autofinanciamento das empresas, reduzindo as pressões de financiamento das empresas sobre o Tesouro Nacional". Ademais, cumpre lembrar que as empresas concessionárias, também, poderiam aplicar a correção monetária sobre os ativos imobilizados para efeitos de avaliação do investimento a ser remunerado, sobre as reservas para depreciação e amortização e sobre os saldos devedores de empréstimos contraídos junto ao BNDE e à Eletrobrás. Tal medida, com certeza, 
permitiu que as empresas concessionárias pudessem conduzir suas ações internas de forma mais empresarial, uma vez que o realismo tarifário conduzido entre 1968-74 e estendido até 1976/77, minimizou a dependência dessas empresas dos recursos fiscais, tendo em vista o peso do autofinanciamento durante este período. A Tabela 2.10 reflete com precisão, o impacto desta medida no comportamento das tarifas de energia elétrica, que registraram um ganho real da ordem de 93\%, em 1972, quando comparado ao ano de 1963.

Tabela 2.10.

Tarifas de energia elétrica (1963-1973)

base $1964=100$

\begin{tabular}{|c|r|r|}
\hline Ano & Tarifa Média $\left(^{*}\right)$ & Tarifa Fiscal (*) \\
\hline 1963 & 90,67 & 103,46 \\
\hline 1964 & 100,00 & 100,00 \\
\hline 1965 & 139,88 & 164,57 \\
\hline 1966 & 143,63 & 197,15 \\
\hline 1967 & 155,94 & 234,80 \\
\hline 1968 & 138,42 & 222,20 \\
\hline 1969 & 149,69 & 232,85 \\
\hline 1970 & 165,82 & 256,12 \\
\hline 1971 & 163,26 & 253,94 \\
\hline 1972 & 174,80 & 273,00 \\
\hline 1973 & 164,14 & 254,95 \\
\hline
\end{tabular}

(*) Corrigida pelo deflator implícito do PIB

Fonte: Lima (1989, p. 110), extraído da Eletrobrás, Informe Tarifário, nº 1, nov. 89

b) ampliação da participação do IUEE e do Empréstimo Compulsório - EC: Entre 1964 e 1969, várias medidas foram estabelecidas na legislação tributária geral brasileira, que acabaram por privilegiar os tributos diretamente vinculados a aplicações setoriais. No caso específico do setor elétrico, ganha destaque o peso desta orientação sobre suas fontes de financiamento. As receitas provenientes do IUEE e, particularmente, do EC, criado em 1962, com recolhimento iniciado em 1964, transformaram-se em expressivas fontes de financiamento, substituindo as extintas dotações provenientes das esferas governamentais ${ }^{45}$. A Tabela 2.11 demonstra, em termos reais, a expressiva expansão destas duas fontes de financiamento para o setor.

\footnotetext{
${ }^{45}$ Conforme lembrado por Rodrigues e Dias (1994), até 1954, as principais fontes de financiamento do setor eram as dotações orçamentárias, tanto federais como estaduais, que permitiram, inclusive, a construção das seguintes usinas: Paulo Afonso (Chesf), Três Marias (Cemig) e Furnas (Furnas). A partir daí, têm-se, como já visto anteriormente, a criação do Fundo Federal de Eletrificação, em 1954, cabendo ao BNDE a tarefa de gerenciar os 60\% do IUEE pagos pelos estados e municípios, e a criação do IUEE, em 1962.
} 
Tabela 2.11

Arrecadação do IUEE e do empréstimo compulsório (1961-1970)

\begin{tabular}{|c|c|c|}
\hline Ano & $\begin{array}{c}\text { Arrecadação } \\
\text { IUEE (*) }\end{array}$ & $\begin{array}{c}\text { Arrecadação Empréstimo } \\
\text { Compulsório (*) }\end{array}$ \\
\hline 1961 & 29,96 & - \\
1962 & 22,67 & - \\
1963 & 69,89 & - \\
1964 & 100,00 & 100,00 \\
1965 & 189,74 & 233,83 \\
1966 & 273,91 & 282,92 \\
1967 & 116,94 & 189,74 \\
1968 & 138,76 & 207,26 \\
1969 & 171,67 & 236,85 \\
1970 & 283,56 & 376,38 \\
\hline
\end{tabular}

OBS.: $1964=100(*)$ Corrigida pelo deflator implícito do PIB

Fontes: Manoel Pinto de Aguiar. Recursos Financeiros do setor de energia elétrica no Brasil, p. 29; IBGE, Estatísticas históricas do Brasil, v. 3; os dados sobre o Empréstimo Compulsório forma fornecidos pelo DNAEE, apud Lima, J.L. Políticas de Governo e Desenvolvimento do Setor de energia elétrica do Código de Águas à Crise dos Anos 80 (1934-1984), 1995, p. 104.

c) linhas de financiamento externo: Nesse período, ganha espaço o debate sobre a necessidade da participação de poupanças externas dada a incapacidade da poupança nacional em responder ao processo acelerado de crescimento econômico. O apelo a recursos externos, especialmente entre 1968-1973, passa a ser visto como condição sine qua non para viabilizar as altas taxas de crescimento do produto interno. Conforme afirma Cruz (1983, p. 61), "é a partir do final dos anos 60, que a dívida bruta inicia uma trajetória de crescimento acelerado passando de US\$ 3,8 bilhões em fins de 1968, para US\$12,6 bilhões em fins de 1973"46. Foi sob essa perspectiva que o setor elétrico estreitou os vínculos com o sistema financeiro internacional, especialmente a partir da expansão do mercado de eurodólares em final da década de 1970. As linhas de financiamento tradicionais foram, aos poucos, sendo substituídas por empréstimos em moeda estrangeira, contraídos junto aos bancos privados internacionais. A Tabela 2.12 reflete esse movimento, revelando um incremento de 10 pontos percentuais da participação do financiamento em moeda externa dentre as fontes de recursos do setor, ao elevar-se para $23 \%$, em 1972, no comparativo ao ano de 1967. Em contrapartida, verifica-se, no mesmo período, uma expressiva queda do aporte de capital público e de financiamento em

\footnotetext{
${ }^{46}$ Para entender melhor a evolução do processo de endividamento externo brasileiro, recomenda-se Cruz (1983).
} 
moeda nacional, compensada, ainda, com a criação da Reserva Global de Reversão (RGR), em 1972, detalhada a seguir.

Tabela 2.12

Participação (\%) das fontes de recursos do setor de energia elétrica (1967/1973)

\begin{tabular}{|l|c|c|c|c|c|c|c|}
\hline Especificação & $\mathbf{1 9 6 7}$ & $\mathbf{1 9 6 8}$ & $\mathbf{1 9 6 9}$ & $\mathbf{1 9 7 0}$ & $\mathbf{1 9 7 1}$ & $\mathbf{1 9 7 2}$ & $\mathbf{1 9 7 3}$ \\
\hline 1. Recursos Próprios & $\mathbf{6 5 , 9 7}$ & $\mathbf{6 5 , 8 3}$ & $\mathbf{5 9 , 3 2}$ & $\mathbf{5 7 , 0 6}$ & $\mathbf{5 5 , 6 0}$ & $\mathbf{6 4 , 0 4}$ & $\mathbf{6 5 , 2 4}$ \\
\hline 1.1 Autofinanciamento & 34,03 & 33,50 & 30,17 & 33,66 & 33,48 & 42,80 & 44,93 \\
Geração Interna & 24,64 & 21,97 & 18,82 & 24,94 & 21,47 & 24,21 & 25,39 \\
IUEE & 4,97 & 6,38 & 6,72 & 6,58 & 8,13 & 9,52 & 10,54 \\
RGR & 0,00 & 0,00 & 0,00 & 0,00 & 0,00 & 8,48 & 10,50 \\
Outros & 4,42 & 5,15 & 4,63 & 2,14 & 3,88 & 0,59 & $-1,50$ \\
1.2. Aporte de Capital & 31,93 & 32,32 & 29,15 & 23,40 & 22,12 & 21,22 & 20,31 \\
Governo & 31,38 & 30,59 & 25,93 & 21,44 & 19,41 & 16,43 & 20,02 \\
\multicolumn{1}{|c|}{ Federal } & 8,01 & 6,85 & 6,84 & 6,19 & 6,83 & 6,34 & 6,80 \\
Estadual & 23,31 & 23,62 & 18,73 & 14,97 & 12,54 & 9,93 & 13,17 \\
Municipal & 0,06 & 0,12 & 0,36 & 0,29 & 0,04 & 0,16 & 0,05 \\
Outros & 0,55 & 1,73 & 3,22 & 1,95 & 2,71 & 4,79 & 0,29 \\
\hline 2. Financiamento & $\mathbf{3 4 , 0 3}$ & $\mathbf{3 4 , 1 7}$ & $\mathbf{4 0 , 6 8}$ & $\mathbf{4 2 , 9 4}$ & $\mathbf{4 4 , 4 0}$ & 35,96 & $\mathbf{3 4 , 7 6}$ \\
\hline Empréstimo Compuls. & 8,01 & 7,91 & 8,21 & 10,38 & 11,53 & 8,86 & 9,37 \\
Em Moeda Nacional & 12,98 & 13,90 & 15,23 & 15,31 & 13,42 & 4,10 & 6,46 \\
Em Moeda Estrangeira & 13,04 & 12,36 & 17,24 & 17,25 & 19,45 & 23,00 & 18,93 \\
Resolução 63 ${ }^{* *}$ & 0,00 & 0,63 & 2,72 & 1,08 & 0,70 & 0,00 & 0,10 \\
Outros & 13,04 & 11,73 & 14,52 & 16,17 & 18,75 & 23,00 & 18,83 \\
\hline 3. Total de Fontes & $\mathbf{1 0 0 , 0 0}$ & $\mathbf{1 0 0 , 0 0}$ & $\mathbf{1 0 0 , 0 0}$ & $\mathbf{1 0 0 , 0 0}$ & $\mathbf{1 0 0 , 0 0}$ & $\mathbf{1 0 0 , 0 0}$ & $\mathbf{1 0 0 , 0 0}$ \\
\hline
\end{tabular}

(*) Resolução 63, trata-se de empréstimo indexado à variação cambial, destinado a financiar as necessidades de capital de giro em geral, sendo os recursos normalmente aplicados para suprir eventuais necessidades do CAIXA da empresa, para reposição de estoques, pagamento de impostos e outras. Essa opção de empréstimo foi amplamente difundida ao longo da década de 70, como forma de captação de recursos externos.

Fonte: Eletrobrás, extraído de Lima, J.L. Políticas de Governo e desenvolvimento do setor de energia elétrica: do Código de Águas à crise dos anos 80 (1934-1984).,Rio de Janeiro.

Desse modo, a partir dessas três importantes mudanças, o setor de energia elétrica adquiriu uma expressiva capacidade de financiar sua expansão, traduzindo-se em acentuada ampliação da potência instalada dos sistemas de geração da energia elétrica do país, que passou de 6.355 MW, em 1963, para 15.354 MW, em 1973, significando um crescimento de aproximadamente $142 \%$, explicitado na Tabela 2.13 . 
Tabela 2.13

Setor elétrico: evolução da capacidade instalada e do consumo de energia elétrica

(1963-1973)

\begin{tabular}{|c|c|c|c|c|c|c|}
\hline \multirow[b]{2}{*}{ Ano } & \multicolumn{3}{|c|}{ Capacidade (em MW) } & \multicolumn{3}{|c|}{ Consumo (em GWh) } \\
\hline & Total & Hidráulica & Térmica & Total & Industrial & Outros \\
\hline 1963 & 6.355 & 4.479 & 1.876 & 22.618 & 11.555 & 11.063 \\
\hline 1964 & 6.840 & 4.894 & 1.946 & 23.521 & 11.958 & 11.563 \\
\hline 1965 & 7.411 & 5.391 & 2.020 & 24.268 & 12.108 & 12.160 \\
\hline 1966 & 7.566 & 5.524 & 2.042 & 26.494 & 13.596 & 12.898 \\
\hline 1967 & 8.042 & 5.787 & 2.255 & 27.988 & 13.861 & 14.127 \\
\hline 1968 & 8.555 & 6.183 & 2.372 & 31.399 & 16.166 & 15.283 \\
\hline 1969 & 10.262 & 7.857 & 2.405 & 34.201 & 17.266 & 16.935 \\
\hline 1970 & 11.233 & 8.828 & 2.405 & 37.673 & 19.345 & 18.328 \\
\hline 1971 & 12.670 & 10.244 & 4.426 & 42.487 & 22.094 & 20.393 \\
\hline 1972 & 13.249 & 10.721 & 2.528 & 47.374 & 25.024 & 22.350 \\
\hline 1973 & 15.324 & 12.495 & 2.859 & 52.842 & 28.532 & 24.310 \\
\hline
\end{tabular}

Fonte: IBGE. Estatísticas Históricas do Brasil, v. 3, apud Lima, J.L. Políticas de Governo e Desenvolvimento do Setor de energia elétrica do Código de Águas à Crise dos Anos 80 (19341984), 1995, p. 144.

Neste período, observa-se, ainda, o crescimento do Grupo Eletrobrás, com a criação de novas empresas controladas. As Centrais Elétricas do Sul do Brasil - Eletrosul foi constituída, em 23/12/1968, e seu funcionamento autorizado apenas em 1969, através do Decreto 64.395, que permitiu, também, a continuidade da Usina de Passo Fundo, no Rio Grande do Sul. Em 1972, foi criada a Centrais Elétricas do Norte - Eletronorte, destinando $10 \%$ da arrecadação do EC à subscrição e aumento do capital do Grupo Eletrobrás.

Completando a fase de consolidação da holding federal e a centralização do setor em suas mãos, ocasionando uma progressiva restrição da autonomia da esfera estadual, devem-se registrar, também, a ocorrência, entre 1971 e 1973, de outras medidas, tais como:

$1^{\circ}$ ) Publicação da Lei 5.655, em 1971, que alterou as seguintes condições de funcionamento do setor:

a) elevação da taxa de remuneração legal do investimento de $10 \%$ para $12 \%$;

b) redução das alíquotas do imposto de renda incidentes sobre os lucros das empresas concessionárias de $17 \%$ para $6 \%$; e 
c) transferência para a Eletrobrás do recolhimento dos recursos provenientes da quota de reversão, com a criação da Reserva Global de Reversão (RGR). É oportuno lembrar que, até então, esse recolhimento era mantido pela própria concessionária para financiamento de programas de investimento. Com a modificação da sistemática de arrecadação da quota de reversão, que passou a ser gerida, exclusivamente, pela Eletrobrás, a RGR tornou-se um fundo com possibilidade de transferência para outras regiões, a critério da própria holding federal e não mais da concessionária.

$2^{\circ}$ ) A Assinatura do Tratado de Itaipu, em 1973, que estabeleceu:

a) a criação de entidade binacional, constituída em partes iguais pela Eletrobrás e pela ANDE, destinada a construir e operar a Usina de Itaipu, com potência instalada de 12.600 MW; e

b) a obrigatoriedade da aquisição da energia de Itaipu pelas regiões Sul, Sudeste e Centro-Oeste de toda a parcela destinada ao Brasil ${ }^{47}$, discriminando o universo de empresas públicas e privadas, geradoras e distribuidoras, que se obrigavam a adquirir toda a energia suprida por aquelas subsidiárias da Eletrobrás ${ }^{48}$.

$3^{\circ}$ ) Reorganização do Grupo Eletrobrás reagrupando suas empresas controladas em quatro concessionárias de âmbito regional - Eletronorte, Chesf, Furnas e Eletrosul -, garantindo, assim, a transferência de carga entre Itaipu e os diversos sistemas regionais, com a cobertura de todo o território nacional.

$4^{\circ}$ ) Instituição dos Grupos Coordenadores para Operação Interligada - GCOI, que se tornaram os responsáveis pela coordenação operacional dos sistemas das regiões sul e

\footnotetext{
${ }^{47}$ Essa obrigatoriedade implica, para as concessionárias desses estados, a indexação institucional à taxa de câmbio e aos juros externos de um importante componente de seu custo operacional, ou seja, energia comprada para revenda. Essa medida, como alerta Lima (1996, p. 151), não acarretaria distorções em suas estruturas de custos, enquanto o comportamento dessas variáveis não se tornasse substancialmente discrepante das variáveis que compõem suas receitas.

${ }^{48}$ Foi estabelecido, por exemplo, conforme ilustrado por Lima (1996, p. 151), que "44\% do total de energia produzida por Itaipu deve ser adquirido pelo Estado de São Paulo a uma tarifa - denominada "tarifa pelo passivo" - suficiente para cobrir os custos operacionais e os encargos financeiros da geradora, determinados, na sua maior parte, pela participação de créditos externos e investimento. Na prática, significa impor aos consumidores das regiões mais ricas o ônus relativo ao pagamento do empreendimento". Ademais, como explora Prado (1996, p. 86), com esta determinação pela primeira vez o governo federal acabou por criar restrições explícitas à expansão de capacidade das empresas concessionárias estaduais.
} 
sudeste, destacando o compromisso de priorizar a utilização da potência e energia produzidas na central elétrica de Itaipu. Tais grupos eram compostos por representantes do DNAEE, da Eletrobrás e das empresas geradoras e distribuidoras da região.

Em final de 1974, através do Decreto Lei 1.383, o governo federal instituiu a equalização tarifária em todo o território nacional, com a criação da Reserva Global de Garantia - RGG, “instrumento que processava a transferência de recursos das concessionárias superavitárias para as deficitárias, de forma que a remuneração de cada empresa se situasse em torno da remuneração média do setor" ${ }^{\star 49}$. Com isso, pretendia-se viabilizar os sistemas de fornecimento de energia elétrica em regiões mais distantes dos centros consumidores, onde o custo do serviço era muito alto.

$\mathrm{Na}$ prática, entretanto, essa medida criou um elemento adicional na estrutura de custos das empresas, em especial para aquelas situadas nas regiões Sul e Sudeste, que passaram a transferir excesso de remuneração para as empresas do Norte e Nordeste, sem efeito sobre suas taxas de rentabilidade, uma vez que havia o repasse direto desses aumentos aos consumidores.

Do exposto, parece ficar evidente que as mudanças realizadas ao longo deste período serviram para reforçar, ainda mais, o modelo organizacional-institucional e econômico-financeiro delineado para o setor durante a década anterior, ao caracterizar-se pela regulação, apropriação e controle dos recursos setoriais pela Eletrobrás, evidenciando sua posição "como agência de planejamento, de financiamento e de holding federal no setor de energia elétrica, controlando empresas atuantes em todo o território nacional e assumindo parcela crescente da produção nacional", conforme adequadamente observa Lima (1995, p. 105). Com isso, na visão do governo federal, estariam sendo criadas todas as condições internas de planejamento e financiamento do setor, capaz de permitir o crescente incremento de sua capacidade instalada, com a predominância de recursos próprios.

\footnotetext{
${ }^{49} \mathrm{O}$ mecanismo para viabilizar essa medida pode ser assim sintetizado: i) até 1971, conforme destacado anteriormente, as concessionárias eram obrigadas a transferir para a RGR, o equivalente a $3 \%$ do investimento remunerado; ii) em 1974, esse percentual foi elevado para 5\%, tendo sido estabelecido que $40 \%$ dos recursos gerados deveriam ser depositados nessa nova conta, ou seja, RGG; e iii) a Eletrobrás passaria a transferir, progressivamente, recursos dessa conta para as empresas cuja estrutura de custos fosse incompatível com a tarifa nacional. Para melhores esclarecimentos ver Lima (1995, p. 123).
} 
De fato, ao se avaliar o comportamento dos investimentos realizados no início da década de 70, que revelou uma média anual de crescimento da ordem de $19 \%$ entre 1970 e 1973, é fácil perceber que a opção de financiamento, acima delineada, contribuiu em muito para tal resultado, ver Tabela 2.14. Dessa forma, em que pese à existência de algum tipo de conflito entre as empresas estaduais e a Eletrobrás, o modelo, em meados dos anos 70, parecia viabilizar a sustentação do crescimento do setor.

Tabela 2.14

Energia elétrica: inversões - Cr\$ Milhões

1969 - 1973

\begin{tabular}{|c|c|c|c|}
\hline Ano & $\begin{array}{c}\text { Valores } \\
\text { Correntes }\end{array}$ & $\begin{array}{c}\text { Valores Reais } \\
\text { Base 1977 }\end{array}$ & $\begin{array}{c}\text { Taxa de } \\
\text { Crescimento Anual }\end{array}$ \\
\hline 1969 & $2.484,9$ & 143,98 & 1,1 \\
\hline 1970 & $3.725,2$ & 189,07 & 31,3 \\
\hline 1971 & $4.920,4$ & 215,21 & 13,8 \\
\hline 1972 & $6.754,4$ & 253,50 & 17,8 \\
\hline 1973 & $8.847,2$ & 290,05 & 14,4 \\
\hline
\end{tabular}

Fonte: Eletrobrás, extraído de Reischstul, H.P. e Coutinho, L.C "Investimento Estatal 1974-1980:

Ciclo e Crise", in Belluzzo L.G.M. \& Coutinho, R. Desenvolvimento Capitalista no Brasil n. ${ }^{\circ}$ 2, ensaios sobre a crise, 2. ${ }^{a}$ edição, Editora Brasiliense, 1983.

Ocorre, entretanto, que, no início dos anos 70, o mundo vivenciou o primeiro choque do petróleo, com a elevação substancial do principal elemento da matriz energética mundial, e o rompimento do acordo internacional firmado ainda durante a Segunda Guerra Mundial de procurar estabilizar as taxas de câmbio internacional.

Assim, em resposta à crise mundial de petróleo e fugindo totalmente da política de ajuste adotada pela maioria dos países centrais, o governo recém empossado implementou o II Plano Nacional de Desenvolvimento - II PND, que acabou representando a orientação central da política econômica brasileira no período de 1975-1979.

Partindo de uma avaliação de que a crise e os transtornos da economia mundial eram passageiros, e ignorando a mudança de sinal ocorrida no cenário internacional, o II PND revelou ser,

"um imenso programa de investimentos, cuja metas eram: (1) substituição das importações de produtos industriais básicos (como aço, alumínio, cobre, fertilizantes, produtos petroquímicos) e bens de capital; e (2) rápida expansão da infra-estrutura econômica (energia hidráulica e nuclear, produção de álcool, transportes e comunicações)", Baer (1996. p. 106). 
Na verdade, como bem destaca Barros e Souza (1985, p. 32/33), a solução proposta pelo governo era extremamente ousada, pelo menos, por três razões em particular:

$\left.1^{\circ}\right)$ mudança de rota defendida em meio a um mundo em recessão e com a economia interna também tendendo à desaceleração. Apenas para ilustrar, verifica-se que, entre 1968-1973, o PIB atingiu taxas médias anuais em torno de $11 \%$, reduzindo-se para $8,15 \%$ e 5,17\%, respectivamente, em 1974 e 1975, dando sinais de que o ciclo expansivo estava terminando. Da mesma forma, as relações comerciais com o resto do mundo foram revelando uma mudança de sinal, que se acentuou, particularmente, a partir de 1974, com o registro de expressivos déficits, explicado pelo comportamento das importações que praticamente duplicaram de valor, em reposta à quadruplicação do preço do petróleo, ocorrida naquele ano. Neste cenário, a inflação reaparece como foco de tensão, elevando-se de 15,5\% a.a. para 34,5\% a.a., entre 1973-1974, conforme explicitado na Tabela 2.15.

$2^{\circ}$ ) ênfase dada à expansão de ramos produtores de bens intermediários: a nova política tentava reorientar o processo de crescimento econômico, minimizando apoio a setores ligados a bens de consumo duráveis, marca da estratégia de crescimento até então adotada pelo país. Com isso, optam por investir pesadamente em setores produtores de insumos básicos e de bens de capital, privilegiando, inclusive, as atividades consideradas eletrointensivas caracterizadas pelo expressivo consumo de energia, menosprezando, assim, a gravidade do problema energético pelo qual passava o mundo naquele momento e seus efeitos sobre a matriz energética nacional.

$3^{\circ}$ ) opção por recorrer a empréstimos externos, como forma de viabilizar a decisão de levar adiante o processo de desenvolvimento, em lugar de se implementar um ajustamento interno, que, com certeza, iria interromper o surto de investimento anterior. 
Tabela 2.15

Taxa de inflação, evolução do PIB e balança comercial (valores FOB)

\begin{tabular}{|c|c|c|c|c|c|}
\hline Ano & $\begin{array}{c}\text { IGP-DI } \\
\mathbf{( \% )}\end{array}$ & $\begin{array}{c}\text { PIB } \\
\mathbf{( \% )}\end{array}$ & $\begin{array}{c}\text { Exportações } \\
\text { (US\$ milhões) } \\
\text { (FOB) }\end{array}$ & $\begin{array}{c}\text { Importações } \\
\text { (US\$ milhões) } \\
\text { (FOB) }\end{array}$ & $\begin{array}{c}\text { Saldo Balança } \\
\text { Comercial } \\
\text { (US\$ milhões) } \\
\text { (FOB) }\end{array}$ \\
\hline 1968 & 24,8 & 9,80 & 1.881 & 1.855 & 26 \\
\hline 1969 & 18,7 & 9,50 & 2.311 & 1.993 & 318 \\
\hline 1970 & 18,5 & 10,40 & 2.739 & 2.507 & 232 \\
\hline 1971 & 21,4 & 11,34 & 2.904 & 3.247 & -343 \\
\hline 1972 & 15,9 & 11,94 & 3.991 & 4.232 & -241 \\
\hline 1973 & 15,5 & 13,97 & 6.199 & 6.192 & 7 \\
\hline 1974 & 34,5 & 8,15 & 7.951 & 12.641 & -4.690 \\
\hline 1975 & 29,4 & 5,17 & 8.670 & 12.210 & -3.540 \\
\hline 1976 & 46,3 & 10,26 & 10.128 & 12.383 & -2.255 \\
\hline 1977 & 38,6 & 4,93 & 12.120 & 12.023 & 97 \\
\hline 1978 & 40,5 & 4,97 & 12.659 & 13.683 & -1.024 \\
\hline 1979 & 77,2 & 6,79 & 15.244 & 18.084 & -2.839 \\
\hline
\end{tabular}

Fonte: Galvêas (1982, p. 71) e Gremaud et alii (2005, p. 415/416). Elaboração própria.

Evidentemente que o II PND gera polêmica, até hoje, uma vez que diversos autores creditam o processo de endividamento externo brasileiro, verificado no início dos anos 80 , a esta estratégia de desenvolvimento, agravada com a segunda alta nos preços do petróleo, em 1979, que com certeza não era aguardada pela equipe econômica do governo.

Seja como for, há um ponto fundamental que merece ser destacado, tendo em vista a preocupação da presente tese de doutoramento, que passa pela avaliação do papel do Estado como indutor da política de investimentos do país. Neste particular, é notório o esforço feito pelo Estado, no sentido de estimular e orientar as decisões privadas, bem como a ocupação de novos espaços pelas empresas públicas, na expectativa de redirecionar os investimentos para setores selecionados, entendidos como estratégicos, naquele momento do processo de desenvolvimento nacional e, em meio à crise, buscar responder ao estrangulamento externo através da reestruturação do aparelho produtivo.

Conforme ressaltam Castro e Souza (1985, p. 42), “diante da crítica situação com que se defrontava a economia em 1974, o governo que acabava de ser empossado negou-se a delegar ao mercado a condução das decisões econômicas". Assim, completam os autores, o Estado passou a lançar mão de sua força e de instrumentos direta ou indiretamente comandados por ele, de maneira a reforçar sua capacidade de direcionar recursos para sua 
finalidade. Citam como exemplo, a transferência de fundos como o PIS e o PASEP para o controle do BNDES, com o propósito de assegurar o financiamento de investimentos em áreas vitais para o desenvolvimento econômico brasileiro e não para o consumo de duráveis.

Como forma de ilustrar as posições de alguns empresários e ministros referentes aos projetos que deveriam ser prioritários no âmbito do II PND, o Quadro 2.1. reproduz sob a forma de escalas de prioridade, as recomendações feitas ao governo por esses agentes econômicos, em outubro de 1976.

Quadro 2.1.

Prioridades de Governo

\begin{tabular}{|l|l|}
\hline \multicolumn{1}{|c|}{ Segundo Empresários } & \multicolumn{1}{c|}{ Segundo Ministros } \\
\hline Itaipu & Prospecção de Petróleo \\
\hline Ferrovia do Aço & Expansão da Siderurgia \\
\hline Expansão da Siderurgia & Transportes Urbanos \\
\hline Prospecção de Petróleo & Saneamento Básico \\
\hline Programa Nuclear & Ferrovia do Aço \\
\hline Saneamento Básico & Telecomunicações \\
\hline Transportes Urbanos & III Pólo Petroquímico \\
\hline III Pólo Petroquímico & Programa Rodoviário \\
\hline Programa Rodoviário & Programa Nuclear \\
\hline Telecomunicações & Itaipu \\
\hline
\end{tabular}

Fonte: Castro e Souza (1985, p. 43), cuja informação foi extraída da Revista Exame, 13/10/76, a partir de consulta realizada com 3 ministros e 12 empresários, dirigentes das empresas: Bergamo, Brown Boveri, C.B.P.Q., Cobrasma, Confab, Conforja, Construtora Alcindo Vieira, Ecisa, Heleno \& Fonseca, Santa Matilde e Ultra, cf. Lessa (1978, p. 163/164).

No caso específico do setor elétrico, a prioridade do governo federal recaiu no aumento da produção de energia elétrica ${ }^{50}$ e nuclear, o que levou a investimentos crescentes, até final da década de 70, conforme se verifica na Tabela 2.16.

\footnotetext{
${ }^{50}$ A Usina Hidrelétrica de Itaipu mereceu especial atenção no âmbito do II PND, por se tratar de um empreendimento binacional envolvendo estrategicamente Brasil e Paraguai, com vistas ao aproveitamento hidrelétrico do Rio Paraná, cujas negociações caminhavam desde a década de 60. Embora, em 1970, o consórcio formado pelas empresas IECO (dos Estados Unidos da América) e ELC (da Itália) venceu a concorrência internacional para a realização dos estudos de viabilidade e para a elaboração do projeto da obra, somente em maio/1974, foi criada a entidade binacional Itaipu, com a tarefa de gerenciar a construção da usina, cujo início efetivo das obras ocorreu apenas em janeiro do ano seguinte, dado o empenho do governo federal.
} 
Tabela 2.16

Energia elétrica: inversões - Cr\$ Milhões

$1974-1980$

\begin{tabular}{|c|c|c|c|}
\hline Ano & $\begin{array}{c}\text { Valores } \\
\text { Correntes }\end{array}$ & $\begin{array}{c}\text { Valores Reais } \\
\text { Base 1977 }\end{array}$ & $\begin{array}{c}\text { Taxa de } \\
\text { Crescimento Anual }\end{array}$ \\
\hline 1974 & $12.973,5$ & 318,88 & 9,9 \\
\hline 1975 & $20.961,8$ & 391,75 & 22,9 \\
\hline 1976 & $33.025,9$ & 456,01 & 16,4 \\
\hline 1977 & $52.652,1$ & 526,52 & 15,5 \\
\hline 1978 & $82.516,0$ & 618,10 & 17,4 \\
\hline 1979 & $126.515,0$ & 605,33 & $-2,1$ \\
\hline 1980 & $246.667,0$ & 547,05 & $-9,6$ \\
\hline
\end{tabular}

Fonte: Eletrobrás, extraído de Reischstul, H.P. e Coutinho, L.C "Investimento Estatal 1974-1980: Ciclo e Crise", in Belluzzo L.G.M. \& Coutinho, R. Desenvolvimento Capitalista no Brasil n. ${ }^{\circ}$ 2, ensaios sobre a crise, 2. ${ }^{a}$ edição, Editora Brasiliense, 1983.

Destaque-se, ainda, que para definir essa expansão, o governo federal valeu-se do conceito de intensidade energética que expressa o coeficiente de relação existente entre o uso de energia total e o produto econômico, geralmente Produto Interno Bruto - PIB, de uma economia no tempo " $n$ ". Em outras palavras, o coeficiente de intensidade energética do PIB expressa a quantidade de energia associada a uma unidade de PIB ("x" tEP/US\$ 1, por exemplo), de tal forma que sua aplicação ao produto econômico resulta no uso total de energia do país no tempo " $n$ ".

Assim, tomando como referência o Plano $90^{51}$, que previu, em suas projeções, uma taxa de crescimento para o PIB da ordem de 10\% a.a. entre 1974 e 1979, e, no mínimo, de $8 \%$ a.a. entre 1979 e 1990, foi projetado um ritmo de crescimento do consumo de energia elétrica superior a 12\% a.a. no período de 1975-1980 e em torno de 10\% a.a. no período de 1980-1990, de maneira a adequar a capacidade instalada à previsão de incremento da atividade econômica do país no período em questão. Tais projeções sinalizaram para uma expansão da capacidade instalada da ordem de $30.000 \mathrm{MW}$ até o final de 1980, lembrando que, em 1974, o Brasil possuía 17.500 MW.

Dentre os investimentos listados, Lima (1995, p. 121) ressalta que,

"além da construção da Usina de Itaipu, o plano previa a implantação de usinas de

\footnotetext{
${ }^{51}$ O Plano 90 previa, ainda, para início da década de 80, os programas de interligação das regiões NorteNordeste e Sudeste/Sul e os primeiros projetos na área nuclear, através da instalação de três centrais em Angra dos Reis. A esse plano, seguiram-se o Plano 95 e o Plano 2000, que valorizaram a eletricidade como um insumo, aumentando sua participação no consumo global do país, de 23,1\%, em 1974, para 29,1\%, em 1979. Para maiores detalhes ver Sauer (2002).
} 
grande porte, com destaque para Tucuruí (4.000 MW), no Rio Tocantis, primeiro grande empreendimento da região amazônica; Itaparica (2.500 MW), Sobradinho (1.050 MW) e Paulo Afonso IV (2.500 MW), todas no Rio São Francisco; Itumbiara (2.100 MW), Emborcação (1.000 MW) e Porto Primavera (1.800 MW) na região Sudeste; Salto Santiago (2.000 MW), Foz de Areia (2.500 MW) e Ilha Grande (2.000 MW) na região Sul"

Cumpre destacar, entretanto, que para essa nova etapa de crescimento, o setor contou com um novo padrão de financiamento, centrado na captação de recursos externos. $\mathrm{Na}$ verdade, as empresas estatais, por determinação governamental, passaram a ter acesso facilitado ao sistema financeiro internacional, encontrando na reciclagem dos petrodólares $^{52}$, um ambiente de liquidez internacional, favorável à contratação de empréstimos externos. A Tabela 2.17 ilustra, claramente, este movimento, destacando o peso assumido pelo setor de energia, dentre as captações realizadas pelo setor público, neste período.

Tabela 2.17.

Estrutura dos ingressos brutos anuais, segundo a propriedade do capital do tomador, com destaque para participação do setor de energia

(1972-1980) em \%

\begin{tabular}{|c|c|c|c|c|c|c|c|c|c|}
\hline Discriminação & $\mathbf{1 9 7 2}$ & $\mathbf{1 9 7 3}$ & $\mathbf{1 9 7 4}$ & $\mathbf{1 9 7 5}$ & $\mathbf{1 9 7 6}$ & $\mathbf{1 9 7 7}$ & $\mathbf{1 9 7 8}$ & $\mathbf{1 9 7 9}$ & $\mathbf{1 9 8 0}$ \\
\hline PÚBLICO & 24,9 & 39,7 & 35,3 & 50,4 & 51,1 & 51,5 & 60,2 & 76,8 & 76,6 \\
\hline Energia & 3,6 & 5,0 & 3,6 & 4,8 & 4,9 & 12,2 & 15,5 & 18,5 & 25,1 \\
\hline PRIVADO & 75,1 & 60,3 & 64,7 & 49,6 & 48,9 & 48,5 & 39,8 & 23,2 & 23,4 \\
\hline
\end{tabular}

Fonte: BACEN, extraído de Cruz, P.D. "Notas sobre o Endividamento Externo Brasileiro nos Anos 70", in Belluzzo L.G.M. \& Coutinho, R. Desenvolvimento Capitalista no Brasil n. ${ }^{\circ}$ 2, ensaios sobre a crise, 2. ${ }^{a}$ edição, Editora Brasiliense, 1983.

Verifica-se que, entre os anos de 1972 a 1976, o setor de energia respondia em média por 4\% do total captado, tendo, a partir de 1977, ampliado significativamente sua participação, atingindo em 1980, o patamar de $25 \%$ do total de ingressos brutos realizados, ultrapassando, inclusive, ao percentual efetivado pelo setor privado, que foi da ordem de $23 \%$.

\footnotetext{
${ }^{52}$ O termo "petrodólares" foi criado neste período para designar, conforme define Lacerda (2002, p. 123), "os imensos excedentes que os países árabes exportadores de petróleo começavam a acumular com o aumento dos preços do produto".
} 
A partir desse momento, começa a se modificar a estrutura de financiamento do setor, onde a participação dos recursos próprios acaba, progressivamente, sendo substituída pela de origem externa ${ }^{53}$. Particularmente, esse efeito é acentuado em 1984, quando o financiamento em moeda estrangeira alcança o patamar de $49,65 \%$ no total das fontes de recursos usados pelo setor, conforme pode ser verificado na Tabela 2.18.

Tabela 2.18

Fontes de recursos do setor de energia elétrica (anos selecionados entre 1974/1984) em \%

\begin{tabular}{|c|c|c|c|c|c|c|}
\hline Especificação & $\mathbf{1 9 7 4}$ & $\mathbf{1 9 7 6}$ & $\mathbf{1 9 7 8}$ & $\mathbf{1 9 8 0}$ & $\mathbf{1 9 8 2}$ & $\mathbf{1 9 8 4}$ \\
\hline 1. Recursos Próprios & $\mathbf{6 7 , 2 0}$ & $\mathbf{6 3 , 0 7}$ & $\mathbf{5 3 , 8 5}$ & $\mathbf{4 7 , 5 8}$ & $\mathbf{5 2 , 9 8}$ & $\mathbf{3 7 , 0 6}$ \\
\hline 1.1 Autofinanciamento & 50,02 & 49,55 & 43,83 & 42,28 & 44,73 & 30,99 \\
\hline Geração Interna & 32,72 & 31,03 & 30,01 & 31,99 & 33,16 & 17,85 \\
\hline IUEE & 8,46 & 6,63 & 5,85 & 4,45 & 3,80 & 2,84 \\
\hline RGR & 8,67 & 9,29 & 8,10 & 6,09 & 8,00 & 9,22 \\
\hline Outros & 0,17 & 2,60 & $(0,13)$ & $(0,25)$ & $(0,23)$ & 1,08 \\
\hline 1.2. Aporte de Capital & 17,18 & 13,52 & 10,02 & 5,30 & 8,25 & 6,07 \\
\hline Governo & 16,36 & 13,03 & 9,95 & 5,26 & 8,25 & 6,01 \\
\hline Federal & 7,65 & 5,83 & 4,02 & 2,27 & 4,95 & 5,14 \\
\hline Estadual & 8,66 & 7,15 & 5,77 & 2,84 & 3,13 & 0,81 \\
\hline Municipal & 0,05 & 0,05 & 0,16 & 0,15 & 0,17 & 0,06 \\
\hline Outros & 0,82 & 0,49 & 0,07 & 0,04 & 0,00 & 0,06 \\
\hline 2. Financiamento & $\mathbf{3 2 , 8 0}$ & $\mathbf{3 6 , 9 3}$ & $\mathbf{4 6 , 1 5}$ & $\mathbf{5 2 , 4 2}$ & $\mathbf{4 7 , 0 2}$ & $\mathbf{6 2 , 9 4}$ \\
\hline Empréstimo Compuls. & 7,34 & 7,01 & 6,33 & 5,41 & 5,31 & 3,87 \\
\hline Em Moeda Nacional & 8,73 & 13,97 & 10,05 & 14,97 & 5,72 & 8,93 \\
\hline Em Moeda Estrangeira & 16,73 & 15,95 & 28,04 & 30,30 & 33,48 & 49,65 \\
\hline Resolução 63 & 0,45 & 1,13 & 1,38 & 6,07 & 4,88 & 0,43 \\
\hline Outros & 16,28 & 14,82 & 26,66 & 24,23 & 28,60 & 49,22 \\
\hline Outros Financiamentos & 0,00 & 0,00 & 1,73 & 1,74 & 2,51 & 0,49 \\
\hline 3. Total de Fontes & $\mathbf{1 0 0 , 0 0}$ & $\mathbf{1 0 0 , 0 0}$ & $\mathbf{1 0 0 , 0 0}$ & $\mathbf{1 0 0 , 0 0}$ & $\mathbf{1 0 0 , 0 0}$ & $\mathbf{1 0 0 , 0 0}$ \\
\hline
\end{tabular}

Fonte: Eletrobrás, extraído de Lima, J.L. Políticas de Governo e desenvolvimento do setor de energia elétrica: do Código de Águas à crise dos anos 80 (1934-1984), Rio de Janeiro.

Essa mudança no padrão de financiamento do setor coincide com o esgotamento dos mecanismos de crescimento da economia brasileira, configurados durante o II PND. A partir de então, o setor público mergulha em um movimento de acentuada crise, onde as restrições tarifárias, fiscais e de crédito externo, rebateram, automaticamente, na base de financiamento e no modelo institucional estabelecidos para o setor de energia elétrica brasileiro, revelando seus limites e fragilidades, a serem analisados no próximo item.

De qualquer modo, pode-se concluir que, de 1964, com a criação da Eletrobrás, até 1979, o setor elétrico brasileiro viveu seu grande período de expansão, cabendo ao Estado a

\footnotetext{
${ }^{53}$ Registre-se que o item 2.3. A crise dos anos 80 e as políticas de ajustamento para o setor elétrico nacional, ao final do presente capítulo, retornará essa questão.
} 
tarefa de indutor e formulador das políticas do setor, consolidando sua posição de agente principal. Esse comportamento permitiu a expansão da capacidade instalada de energia elétrica, em 1979, para 27.970 MW, configurando um aumento de 82,5\% em apenas seis anos, tendo como base o ano de 1973, ver Tabela 2.19.

Tabela 2.19

Setor elétrico: evolução da capacidade instalada e do consumo de energia elétrica

(1973-1979)

\begin{tabular}{|c|c|c|c|c|c|c|}
\hline \multirow[b]{2}{*}{ Ano } & \multicolumn{3}{|c|}{$\begin{array}{l}\text { Capacidade } \\
\text { Instalada (em MW) }\end{array}$} & \multicolumn{3}{|c|}{ Consumo (em GWh) } \\
\hline & Total & Hidráulica & Térmica & Total & Industrial & $\begin{array}{c}\text { Não } \\
\text { industrial }\end{array}$ \\
\hline 1973 & 15.324 & 12.495 & 2.859 & 52.842 & 28.532 & 24.310 \\
\hline 1974 & 17.526 & 14.285 & 3.241 & 58.741 & 31.674 & 27.067 \\
\hline 1975 & 19.056 & 16.150 & 2.906 & 66.013 & 35.616 & 30.397 \\
\hline 1976 & 20.827 & 17.670 & 3.157 & 75.267 & 41.748 & 33.519 \\
\hline 1977 & 22.491 & 19.293 & 3.198 & 83.989 & 46.526 & 37.463 \\
\hline 1978 & 25.300 & 21.740 & 3.560 & 93.699 & 52.438 & 41.261 \\
\hline 1979 & 27.970 & 24.265 & 3.705 & 104.825 & 58.791 & 46.034 \\
\hline
\end{tabular}

Fonte: IBGE. Estatísticas Históricas do Brasil, v. 3, apud Lima, J.L. Políticas de Governo e Desenvolvimento do Setor de energia elétrica do Código de Águas à Crise dos Anos 80 (1934-1984), 1995, p. 144.

\subsection{A crise dos anos 80 e os efeitos das políticas de ajustamento para o setor elétrico nacional}

Ao se tentar avaliar os fatores que influenciaram a crise do setor elétrico brasileiro, dois pontos merecem especial atenção: i) o primeiro relaciona-se à subordinação do setor aos interesses da política macroeconômica, nem sempre sintonizada aos objetivos setoriais; e ii) o segundo trata-se do surgimento de contradições internas ao próprio setor decorrentes do modelo institucional e econômico-financeira organizado.

Como visto, de forma a atingir os objetivos propostos pelo II PND, a holding Eletrobrás assim como as demais empresas estatais brasileiras foram estimuladas a captar recursos externos como forma de financiar seus expressivos investimentos. Registre-se que, 
em 1978, tais inversões representaram mais de $10 \%$ do volume global de investimentos realizados no país ${ }^{54}$, assumindo papel de destaque na sustentação do investimento estatal "anticíclico" do período. Com isso, há uma estratégia deliberada do governo federal em viabilizar crescimento interno com endividamento externo, que acabou por redundar na própria estatização da dívida externa brasileira ${ }^{55}$.

Em final da década de 70, entretanto, o segundo choque do petróleo e a alta dos juros internacionais revelaram o esgotamento dessa capacidade de endividamento, acelerando o processo de estrangulamento econômico-financeiro do setor público. Nesse ambiente, diversas medidas foram implementadas visando administrar a crise financeira interna e externa do setor público e do balanço de pagamentos, subordinando as diversas esferas administrativas às exigências da política macroeconômica.

No caso específico do setor elétrico, têm se o esgotamento das transferências de recursos fiscais para o setor, a utilização das tarifas como instrumento de política antiinflacionária e de promoções às exportações, e a subordinação das captações de recursos externos à política de administração da dívida externa. $\mathrm{O}$ efeito imediato desta estratégia foi, de um lado, comprometer o relativo grau de autonomia conquistado pelo setor, em especial durante o período de 1970/75, particularmente no que se refere à política tarifária, e de outro, revelar os limites do sistema de transferências intrasetorial (RGG e RGR). Isto porque, tal esquema sempre foi aceito e viabilizado pelas empresas fornecedoras líquidas de recursos, enquanto as tarifas praticadas baseavam-se em critérios internos ao setor (custos de operação e expansão), sendo suficientes para garantir às empresas a remuneração legal de $10 \%$ a $12 \%$ a.a. Com a deterioração tarifária, conforme aponta Lima (1996, p. 153/154), o recolhimento das quotas RGG e RGR passou a afetar negativamente a rentabilidade das empresas recolhedoras, por serem tais quotas definidas em função do capital investido e não da receita tarifária. Ademais, como o equalizador da taxa de remuneração do setor (RGG) estabelecia o recolhimento para as empresas que obtivessem remuneração superior a $10 \%$, as empresas praticamente cessaram as transferências internas de recursos, em resposta à queda de seus níveis de remuneração.

\footnotetext{
${ }^{54}$ Sauer (2002, p. 122)

${ }^{55}$ Para se ter uma análise mais detalhada do processo de estatização da dívida externa brasileira ver, por exemplo,

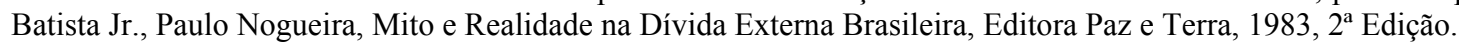


Assim, na tentativa de continuar viabilizando esse procedimento, em 1981, foi criada a "figura da Remuneração Média do Setor, que estabelecia, como base de cálculo da RGG, a diferença positiva entre a remuneração do concessionário e a remuneração média do setor" ${ }^{\text {"56 }}$. Com essa nova metodologia de cálculo, voltaram a ocorrer transferências de recursos das concessionárias da região Sudeste para as regiões deficitárias.

Ao mesmo tempo, o recolhimento devido da RGR foi elevado de 3\% para 4\%, como forma de socializar o impacto da restrição tarifária para o conjunto das concessionárias e preservar, conforme bem colocou Lima (1996, p. 154), "em meio à crise setorial, o modelo centralizador de recursos através do fortalecimento da Eletrobrás na sua função de holding fornecedora de capital de empréstimo".

Um outro efeito da restrição tarifária foi o crescimento acelerado dos direitos das concessionárias registradas na Conta de Resultados a Compensar (CRC). Como relatado anteriormente, estabelecida em 1971, a CRC, na prática, passou a representar um crédito das concessionárias contra a União, como se o poder concedente, por qualquer razão, não tivesse conseguido estabelecer um nível tarifário suficiente para garantir o equilíbrio econômico-financeiro das concessionárias. Assim, a legislação do setor estabelecia que as diferenças negativas ou positivas entre a remuneração efetiva do concessionário e a garantida por lei seriam depositadas (sendo maior) ou registradas (sendo menor) na referida conta. É evidente que, com a queda da remuneração, crescia o débito na CRC, representando, formalmente, uma dívida do setor público para com as empresas ${ }^{57}$.

A Tabela 2.20 tenta sintetizar esse conjunto de informações ao demonstrar o comportamento de tais indicadores setoriais, com a inclusão da evolução das receitas de IUEE e dos EC, duas fontes de recursos que também sofreram forte contração ao longo do período 1980-1991, comprometendo, ainda mais, as condições de financiamento do setor.

\footnotetext{
${ }^{56}$ Lima (1996, p. 154) exemplifica este novo procedimento da seguinte forma: uma concessionária da região Sudeste com taxa de remuneração de $9,5 \%$, que no sistema anterior não fazia transferência, passou a fazê-lo se na média nacional, a remuneração do capital atingisse, por exemplo, $6,5 \%$.

${ }^{57}$ Cumpre lembrar que, a partir de 1979, a CRC passou a ser corrigida monetariamente. Segundo Lima (1996, p. 154), "em 1980, o valor acumulado equivalia a $25 \%$ do investimento daquele ano; em 1983, representava já $50 \%$ do investimento do exercício".
} 
Tabela 2.20

Tarifa de fornecimento, taxa de remuneração média, IUEE, EC, CRC e RGR 1980-1991

\begin{tabular}{|c|c|c|c|c|c|c|}
\hline Ano & \begin{tabular}{l}
\multicolumn{2}{c}{ Tarifa de } \\
Fornecimento \\
Setorial
\end{tabular} & $\begin{array}{c}\text { Taxa de } \\
\text { remuneração } \\
(\%)\end{array}$ & $\begin{array}{c}\text { IUEE } \\
\text { (2) }\end{array}$ & $\begin{array}{l}\text { EC } \\
\text { (2) }\end{array}$ & $\begin{array}{c}\text { CRC } \\
\text { Acumulada } \\
\text { (2) }\end{array}$ & RGR \\
\hline 1980 & 65,5 & - & 1.717 & 2.003 & - & 2.290 \\
\hline 1981 & 72,1 & 9,1 & 1.911 & 2.048 & 4.823 & 3.640 \\
\hline 1982 & 67,5 & 6,7 & 1.490 & 2.073 & 8.267 & 3.120 \\
\hline 1983 & 58,9 & 4,4 & 1.372 & 1.583 & 13.587 & 3.495 \\
\hline 1984 & 54,5 & 5,8 & 1.341 & 1.832 & 18.026 & 4.361 \\
\hline 1985 & 56,8 & 5,1 & 1.462 & 1.962 & 24.857 & 2.989 \\
\hline 1986 & 50,9 & 3,7 & 1.681 & 2.268 & 32.753 & 1.485 \\
\hline 1987 & 62,1 & 4,9 & 1.268 & 1.563 & 39.050 & 2.184 \\
\hline 1988 & 61,3 & 5,8 & 911 & 1.604 & 36.008 & 58 \\
\hline 1989 & 45,5 & 4,8 & 214 & 1.366 & 29.913 & 613 \\
\hline 1990 & 48,9 & - & - & 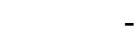 & - & - \\
\hline 1991 & 46,7 & & & & & \\
\hline
\end{tabular}

(1) em US\$/MWh. (2) em NCZ\$ milhões constantes de 1989

Fonte: Eletrobrás, elaborado a partir de Lima (1996, p.193/194)

Com esse cenário, era de se esperar que fossem intensificados os conflitos entre as Eletrobrás e as concessionárias supridoras líquidas de recursos à RGR e RGG, que passaram a boicotar o sistema, recusando-se a efetuar os recolhimentos. Como resultado, as concessionárias do Sul/Sudeste deixaram acumular dívidas tanto referentes às tarifas de suprimento (basicamente perante Itaipu) quanto às transferências legais. Por outro lado, essas concessionárias alegavam ter recursos a receber do governo federal, decorrentes da insuficiência da remuneração expressa na $\mathrm{CRC}^{58}$.

Em paralelo, vale a pena registrar a evolução do próprio movimento de endividamento externo, iniciado durante o II PND. Como destacado anteriormente, a maioria das empresas vinculadas ao setor produtivo estatal acabaram se transformando em um instrumento ativo do processo de endividamento externo, base do padrão de financiamento dos anos 70. No caso do setor elétrico, conforme demonstrado através da Tabela 2.18, esse padrão avançou até 1984, elevando sobremaneira sua participação dentre as fontes de recursos disponíveis.

Ocorre, entretanto, que essa opção de financiamento acabou ampliando também o

\footnotetext{
${ }^{58}$ Esse conflito, conforme será discutido no próximo capítulo, só foi superado, em 1993, quando foi aprovado o encontro de contas no âmbito do processo de revisão do sistema elétrico brasileiro, nos termos estabelecidos através da Lei $n^{\circ}$. 8.631/93.
} 
financiamento em moeda nacional, uma vez que as empresas encontraram nas instituições financeiras públicas, um porto seguro para suas operações de refinanciamento de suas obrigações externas, os conhecidos "relending".

A partir de 1985, tendo em vista as distorções e os abusos decorrentes desta prática, o governo federal interrompeu essa opção, o que levou à redução do estoque da dívida externa de longo prazo, porém, a de curto prazo continuou crescendo. Como forma de contornar esse movimento e visando capitalizar as dívidas do setor elétrico, o governo federal acabou intensificando a conversão paulatina das dívidas em moeda estrangeira em Avisos MF, instrumento de transferência do endividamento do setor elétrico para o Tesouro Nacional, que passou a operar efetivamente como mecanismo de financiamento das obrigações externas vencidas, cujo estoque crescia de forma sistemática.

A Tabela 2.21 reproduz a evolução deste movimento ao caracterizar o perfil do endividamento do setor por tipo de moeda e prazo de pagamento, revelando, como bem coloca Lima (1996, p. 166),

“uma forma de 'reestatização' de parte importante da dívida externa, a qual, num primeiro momento, se acumulou nas empresas estatais e, ao longo dos anos 80 , foi definitivamente 'socializada' com sua transferência progressiva para o Tesouro Nacional'.

Tabela 2.21

Perfil do endividamento do setor elétrico, por moeda e prazo, em US\$ milhões, a preços constantes de 1989

\begin{tabular}{|c|r|r|r|r|r|r|r|r|r|r|}
\hline & 1980 & 1981 & 1982 & 1983 & 1984 & 1985 & 1986 & 1987 & 1988 & 1989 \\
\hline & & & & & & & & & & \\
\hline Curto Prazo & 1.689 & 1.871 & 1.262 & 4.050 & 3.162 & 6.486 & 11.423 & 15.132 & 13.536 & 11.113 \\
\hline Moeda Nacional & 760 & 552 & 341 & 512 & 641 & 1.039 & 529 & 718 & 791 & 600 \\
\hline Moeda Estrangeira & 676 & 995 & 807 & 549 & 1.641 & 1.581 & 2.732 & 3.197 & 3.091 & 4.074 \\
\hline Resolução n ${ }^{\circ} 63$ & 253 & 325 & 114 & 782 & 382 & 255 & 1.123 & 602 & 459 & 342 \\
\hline Avisos MF & 0 & 0 & 0 & 2.207 & 498 & 3.611 & 7.038 & 10.615 & 9.163 & 6.097 \\
\hline & & & & & & & & & & \\
\hline Longo Prazo & 13.112 & 16.441 & 18.833 & 23.182 & 26.760 & 28.486 & 23.300 & 21.695 & 17.003 & 9.839 \\
\hline Moeda Nacional & 1.985 & 3.104 & 3.571 & 3.712 & 3.950 & 6.310 & 5.154 & 5.642 & 4.649 & 1.728 \\
\hline Moeda Estrangeira & 10.684 & 12.655 & 14.223 & 17.022 & 20.434 & 21.639 & 17.029 & 15.426 & 12.028 & 7.972 \\
\hline Resolução n ${ }^{\circ}$ 63 & 443 & 681 & 1.040 & 2.448 & 2.376 & 538 & 1.118 & 627 & 327 & 109 \\
\hline & & & & & & & & & & \\
\hline Total Empr.e Financ. & 14.801 & 18.312 & 20.096 & 27.232 & 29.922 & 34.973 & 34.723 & 36.828 & 30.539 & 20.952 \\
\hline & & & & & & & & & & \\
\hline Passivo & 41.594 & 50.458 & 57.996 & 62.145 & 67.128 & 72.641 & 79.135 & 77.646 & 70.520 & 64.257 \\
\hline
\end{tabular}

Fonte: Eletrobrás, extraído de Lima (1996, p. 196). 
Esse conjunto de variáveis ao se agravarem ao longo da década dos anos 80 , explicitaram os problemas decorrentes do modelo institucional, tanto em termos do papel centralizador assumido pela holding Eletrobrás, quanto pela estrutura de autofinanciamento intrasetorial estabelecido, trazendo como resultado uma queda no nível dos investimentos realizados, que só não foi maior em razão da meta de conclusão da Usina Hidrelétrica de Itaipu, que começou a operar em 1985.

De fato, os dados da Tabela 2.22 demonstram uma queda de $51 \%$ no total de investimentos realizado no setor em 1991 em relação a 1980. Já a capacidade instalada registrou um crescimento anual médio da ordem de 4,2\%, excluindo o ano de 1985, quando entra em operação a Usina de Itaipu. Tais resultados, tendo em vista os baixos níveis de atividade econômica registrados no período, expressos em termos de PIB, parecem não ter comprometido o atendimento da demanda. A dúvida que persistia, naquele momento, refere-se ao comportamento do setor, em resposta a uma retomada do crescimento econômico, sinalizada para a década de 90.

Tabela 2.22

Indicadores Selecionados para o período 1980-1991

\begin{tabular}{|c|c|c|c|c|c|c|c|}
\hline \multirow[b]{2}{*}{ Anos } & \multirow[b]{2}{*}{ PIB (\%) } & \multicolumn{2}{|c|}{ Capacidade Instalada } & \multicolumn{2}{|c|}{ Investimentos } & \multicolumn{2}{|c|}{ Consumo Total } \\
\hline & & MW & $\begin{array}{c}\text { variação } \\
\text { anual (\%) }\end{array}$ & $\begin{array}{c}\text { US\$ milhões } \\
(1)\end{array}$ & $\begin{array}{c}\text { variação } \\
\text { anual (\%) }\end{array}$ & GWh & $\begin{array}{c}\text { variação } \\
\text { anual (\%) }\end{array}$ \\
\hline 1980 & 9,20 & 33.472 & - & $8.155,00$ & - & 121.837 & - \\
\hline 1981 & $-4,25$ & 37.269 & 11,34 & $8.624,00$ & 5,75 & 125.141 & 2,71 \\
\hline 1982 & 0,83 & 39.346 & 5,57 & $9.161,00$ & 6,23 & 132.202 & 5,64 \\
\hline 1983 & $-2,93$ & 40.366 & 2,59 & $7.045,00$ & $-23,10$ & 142.620 & 7,88 \\
\hline 1984 & 5,40 & 41.096 & 1,81 & $6.312,00$ & $-10,40$ & 158.517 & 11,15 \\
\hline 1985 & 7,85 & 44.107 & 7,33 & $7.037,00$ & 11,49 & 172.712 & 8,95 \\
\hline 1986 & 7,49 & 44.953 & 1,92 & $6.698,90$ & $-4,80$ & 186.414 & 7,93 \\
\hline 1987 & 3,53 & 47.561 & 5,80 & $9.426,10$ & 40,71 & 192.224 & 3,12 \\
\hline 1988 & $-0,06$ & 49.575 & 4,23 & $7.793,00$ & $-17,33$ & 204.248 & 6,26 \\
\hline 1989 & 3,16 & 52.125 & 5,14 & $6.402,00$ & $-17,85$ & 212.324 & 3,95 \\
\hline 1990 & $-4,35$ & 53.050 & 1,77 & $5.515,00$ & $-13,86$ & 216.535 & 1,98 \\
\hline 1991 & 1,03 & 54.141 & 2,06 & $3.978,90$ & $-27,85$ & 227.660 & 5,13 \\
\hline
\end{tabular}

(1) Informação extraída de Prado (1996, p. 123)

Fonte: IBGE e Balanço Energético Nacional 1996, elaboração própria.

De maneira a atender essa expectativa, deve se registrar que apenas duas iniciativas buscaram reverter este quadro em crise. A primeira foi delineada através do Plano de Recuperação Setorial - PRS, lançado em fins de 1985, que envolvia metas de recuperação 
tarifária e de equacionamento de recursos internos e externos via capitalização. A implementação do Plano Cruzado, em 1986, e, posteriormente, o lançamento do Plano Verão, em 1989, contudo, reverteram eventuais iniciativas de recuperação tarifária, situação necessária para obtenção de créditos do Banco Mundial.

Em 1987, marcando a segunda tentativa, o governo federal criou o Revise - Revisão Institucional do Setor Elétrico, que apresentava dois objetivos centrais: "a) explorar a possibilidade de maior participação da iniciativa privada no setor, buscando formas alternativas para sua atuação; e b) reformular a estrutura institucional e política do setor para a solução dos problemas diagnosticados" ${ }^{\text {"59. }}$.

Apesar dos esforços do governo em conduzir tais mudanças, a década de oitenta foi concluída, sem nenhum tipo de alteração no modelo institucional e de financiamento formulado nos anos anteriores. De fato, a reforma do setor dá sinais de mudanças, apenas a partir de 1990, em um novo contexto internacional, onde a privatização e a desverticalização do setor tornam-se a orientação básica e o discurso oficial da maioria das gestões em curso, o que facilitou a adoção de uma reforma pouco preocupada em equacionar, de fato, os problemas estruturais do setor elétrico, mas sim priorizar o ajuste fiscal da economia como um todo.

${ }^{59}$ Sauer (2002, p. 125) 


\section{CAPÍTULO 3: A REESTRUTURAÇÃO DO SETOR ELÉTRICO BRASILEIRO: a adoção de um novo modelo institucional durante os anos 90 e a revisão no biênio 2003-2004}

\subsection{Um cenário em mutação: a ênfase liberal da política econômica dos anos 90}

Como visto no capítulo anterior, a necessidade de revisão do modelo elétrico brasileiro, desde o final dos anos 80 , era inquestionável. O setor, durante esse período, teve acentuado seu quadro de endividamento externo e interno, resultado, em parte, da estratégia de crescimento econômico adotada durante os anos 70 e do modelo institucional desenhado, que acabou se revelando inadequado, em razão da intensificação dos conflitos federativos. Além disso, as restrições de investimento no setor, em decorrência do esgotamento do padrão de financiamento público, já revelavam, naquela ocasião, os limites de sua expansão, particularmente nos segmentos de geração e transmissão.

Nesse cenário, reorganizar o setor elétrico brasileiro tornava-se imprescindível, em especial no que se refere ao encaminhamento de mudanças institucionais, à revisão da matriz energética, à política tarifária e de financiamento, bem como à eventual participação de agentes privados. A forma, contudo, no enfrentamento dessas questões, está diretamente relacionada ao tipo de atuação pretendida para o Estado brasileiro e a opção de política econômica adotada durante a década de 90 .

De fato, a gestão Collor dá o primeiro passo importante no sentido de alinhar a política econômica nacional à orientação liberal, predominante na época, na qual o saneamento financeiro e reordenamento estratégico do Estado tornam-se os objetivos centrais a serem perseguidos.

Nessa linha, a ênfase fiscal e a preocupação do governo federal de contribuir para a redução da dívida pública levaram, de um lado, à adoção do Programa Nacional de Desestatização - $\mathrm{PND}^{60}$, que acabou por representar a principal estratégia de política econômica a ser dada ao Setor Produtivo Estatal - SPE, e de outro, à condução de um processo de recuperação gradual dos principais preços públicos, de maneira a minimizar

\footnotetext{
${ }^{60}$ O PND foi criado, através da Medida Provisória 155, tendo sido transformada na Lei 8.031, em 12 de abril de 1990. Uma descrição detalhada da evolução do PND, em termos institucionais, pode ser encontrada em Landi, (1998).
} 
aportes de recursos por parte do Tesouro Nacional, bem como sinalizar aos investidores privados a real intenção de se avançar na orientação conhecida como "realismo tarifário", forte aliada de processos de privatizações ${ }^{61}$.

Começando com a alienação das empresas estatais siderúrgicas, petroquímicas e de fertilizantes, o PND tornou-se, naturalmente, no início dos anos 90, uma das peças fundamentais para a consolidação de uma nova estratégia de atuação do Estado brasileiro. Aos poucos, o Estado-empreendedor, que impulsionou o processo de desenvolvimento econômico nacional, vai tentando se adequar ao padrão de Estado fiscalizado/regulador, presente na nova ordem mundial. Essa mudança casa-se, perfeitamente, com as demais transformações em curso no Brasil, em decorrência da orientação neoliberal que assume a política econômica nacional, durante esse período.

Neste particular, é bom ressaltar que até mesmo durante a gestão do Presidente Itamar Franco, que assume o posto em função da saída do então Presidente Fernando Collor de Mello, essa orientação não foi modificada. No que se refere à privatização, por exemplo, foram aprovadas apenas algumas alterações de procedimentos no PND, na tentativa de se permitir uma maior transparência ao processo e melhorar os resultados finais dos leilões. Dessa forma, a preocupação inicial de inserir o programa em uma estratégia mais ampla de política econômica, bandeira defendida por Antônio Barros Castro, economista que assumiu o cargo de Presidente do BNDES, durante o período de outubro de 1992 a março de 1993, acabou sendo abortada, tendo o PND ficando atrelado a uma perspectiva fiscal ${ }^{62}$.

Quanto à política de recuperação tarifária, em curso durante a gestão Collor, os impasses iniciais do Presidente Itamar Franco, envolvendo a discussão sobre a necessidade de se rever, ou até mesmo, conter os reajustes de algumas tarifas consideradas "populares" como GLP, tarifa básica de telefone, ficha telefônica e energia elétrica residencial para a faixa de consumo abaixo de $30 \mathrm{~kW} /$ mês, acabaram por avançar em parte da folga conseguida.

De qualquer forma, em paralelo, várias tentativas foram feitas no sentido de

\footnotetext{
${ }^{61}$ Essa recuperação foi conseguida, ao longo da gestão Collor, em especial a partir de 1991, o que possibilitou patamares reais de relativa folga para tais tarifas, ver Landi e Passanezi Filho (1995).

${ }^{62}$ Uma análise mais detalhada de tais mudanças e da articulação do PND ao enfoque fiscal pode ser vista em Landi (1998).
} 
proceder à revisão dos critérios de correção tarifária, com o objetivo central de definir tarifas mais adequadas à realidade de cada setor, baseada na planilha de custos de cada empresa. Apesar de esta ser uma diretriz recomendável, na prática as autoridades avançaram muito pouco nesta direção, merecendo, entretanto, destaque especial o setor de energia elétrica.

Em março de 1993, após vários meses de negociações, foi aprovada a Lei $8.631 / 93^{63}$, que transferia para as concessionárias de energia elétrica a responsabilidade de fixar e reajustar suas tarifas, de acordo com os custos de cada serviço, abandonando a prática de rentabilidade garantida. Esperava-se que a partir de agosto do mesmo ano, com a implementação da medida, as concessionárias passassem a usar seus custos como variáveis de ajuste, na definição da correção de seus serviços, o que explicaria a rentabilidade proposta.

Infelizmente, dado o cenário de inflação alta, as concessionárias mantiveram a prática então vigente de reajustar os seus preços com base na inflação passada. Em outras palavras, de imediato, a simples decisão de desequalização das tarifas do setor não levou às concessionárias estaduais a adotarem novas práticas de correção de serviços, revelando, talvez, que as mesmas não estivessem sequer habilitadas para implementar essa mudança, no ritmo adequado.

A Tabela 3.1. revela o comportamento dos preços de duas faixas de consumo de energia elétrica selecionadas, com o objetivo de ilustrar sua evolução durante as gestões Collor e Itamar Franco. Os dados revelam uma forte recuperação, em especial, dos preços relativos à faixa de consumo residencial de 101 a $200 \mathrm{kWh}$, que alcançou em termos reais $\mathrm{R} \$ 115,04$, em 1994, representando um aumento da ordem de 48\%, em comparação a 1990. Já a faixa industrial A2, no mesmo período, registrou um crescimento de apenas $9 \%$, em relação a 1990, o que reforçando a tendência de utilização do insumo energia como um subsídio produtivo.

\footnotetext{
${ }^{63} \mathrm{O}$ item 3.2. A reestruturação do setor elétrico e sua regulamentação básica: da Lei $\mathrm{n}^{\mathrm{o}} 8.631 / 93$ à Lei $\mathrm{n}^{\mathrm{o}}$ 9.648/98 abordará com destaque a relevância desta medida pra o processo de reestruturação do setor elétrico brasileiro.
} 
Tabela 3.1.

Preços médios de energia nas gestões Collor e Itamar

Franco

(tarifas selecionadas)

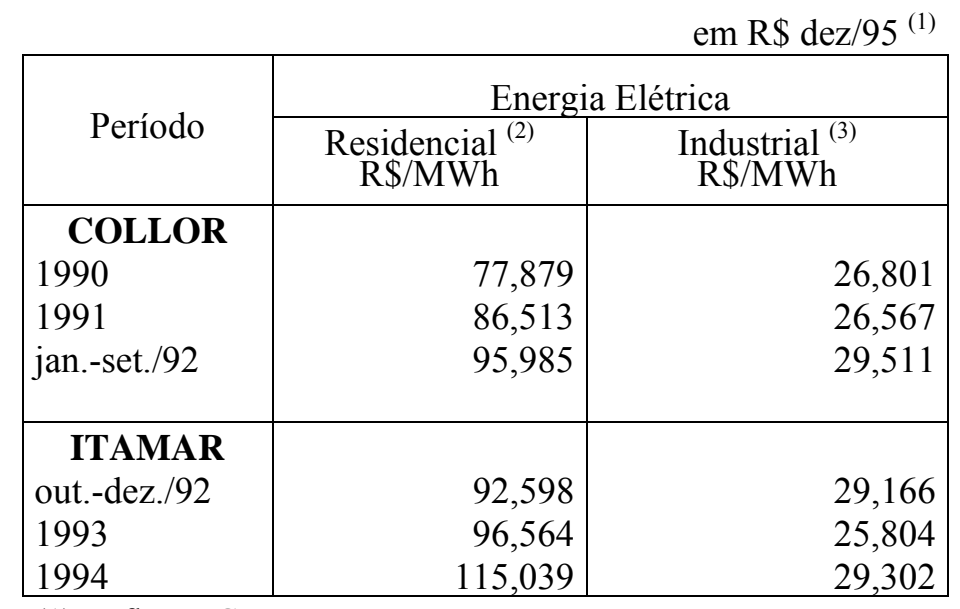

(1) Deflator IGP-DI

(2) Tarifa CESP (R\$ por MWh), para categoria de consumo

residencial na faixa de 101 a $200 \mathrm{kWh}$ (sem ICMS)

(3) Tarifa CESP (R\$ por MWh), para categoria A2, intensidade de 88 a $138 \mathrm{kv}$ (sem ICMS).

Fonte: extraído de Landi, M.e Pessini, J.E. (1998, p. 141)

Com a implementação do Plano Real, por sua vez, o movimento de recuperação tarifária, bem como o fortalecimento do PND, com a previsão da abertura ao capital privado $^{64}$ de setores da infra-estrutura nacional, articularam-se perfeitamente a outros pilares das recomendações do Consenso de Washington, quais sejam: liberalização do mercado e austeridade fiscal.

Além disso, conforme apontam Pinheiro, Giambiagi e Gostkorzewicz (1999, p. 23), “a implementação do Plano Real acabou por eliminar a indexação retroativa, sem a necessidade de um congelamento de preços e salários para conter a inflação - como fora o caso dos planos de estabilização anteriores" ${ }^{\text {65 }}$. Entretanto, a conjugação da apreciação cambial com a abertura comercial, se por um lado, permitiu o uso da âncora cambial no controle da inflação, em razão da severa concorrência externa daí resultante, de outro, esteve associada à deterioração expressivas das contas externas do Brasil, principalmente

\footnotetext{
${ }^{64}$ Registre-se que, nessa época, foram explicitamente incorporadas, à redação original dos objetivos do PND, a privatização de serviços públicos e de instituições financeiras e a redução do estoque e melhoria no perfil da dívida pública.

${ }^{65}$ Planos Cruzado (1986), Bresser (1987), Verão (1989), Collor I (1990) e Collor II (1991).
} 
na primeira gestão do Presidente Fernando Henrique Cardoso (FHC).

Como enfatizam os autores, "os megassuperávits comerciais da segunda metade da década de 80 foram transformados em déficits importantes a partir de 1994", comprometendo, ainda mais, o resultado deficitário da conta corrente do balanço de pagamentos brasileiro, conforme pode ser visto na Tabela 3.2, abaixo relacionada.

Nesse contexto, as autoridades econômicas passam a apostar, cada vez mais, em um expressivo processo de privatização, em especial na alienação dos ativos relacionados às áreas de infra-estrutura, como forma de atrair investidores estrangeiros para esses setores, com o propósito de viabilizar a entrada de recursos externos, necessária para contrabalançar o agravamento do déficit comercial brasileiro, acima explicitado, e minimizar, também, o peso dos investimentos externos provenientes do mercado internacional de capitais, que, mais cedo ou mais tarde, acaba dando sinais constantes de sua volatilidade.

Tabela 3.2.

Principais resultados do balanço de pagamentos do Brasil - em US\$ milhões 1984-1998

\begin{tabular}{|c|c|c|c|c|c|}
\hline Ano & $\begin{array}{c}\text { Balança Comercial } \\
\text { FOB }\end{array}$ & $\begin{array}{l}\text { Serviços } \\
\text { (líquido) }\end{array}$ & $\begin{array}{l}\text { Transações } \\
\text { Correntes }\end{array}$ & $\begin{array}{l}\text { Movimento de } \\
\text { Capitais }\end{array}$ & $\begin{array}{c}\text { Superávit ou } \\
\text { Déficit (-) }\end{array}$ \\
\hline 1984 & 13.089 & -13.215 & 45 & 253 & 700 \\
\hline 1985 & 12.489 & -12.877 & -241 & -2.554 & -3.200 \\
\hline 1986 & 8.305 & -13.695 & -5.304 & -7.108 & -12.356 \\
\hline 1987 & 11.173 & -12.678 & -1.435 & -746 & -2.987 \\
\hline 1988 & 19.184 & -15.103 & 4.175 & 3.635 & 6.977 \\
\hline 1989 & 16.120 & -15.331 & 1.033 & -3.648 & -3.391 \\
\hline 1990 & 10.753 & -15.369 & -3.782 & -4.715 & -8.825 \\
\hline 1991 & 10.579 & -13.542 & -1.407 & -4.148 & -4.679 \\
\hline 1992 & 15.239 & -11.339 & 6.143 & 25.271 & 30.028 \\
\hline 1993 & 13.307 & -15.585 & -592 & 10.115 & 8.404 \\
\hline 1994 & 10.466 & -14.743 & -1.689 & 14.294 & 12.939 \\
\hline 1995 & -3.352 & -18.594 & -17.972 & 29.359 & 13.480 \\
\hline 1996 & -5.554 & -20.483 & -23.137 & 34.263 & 9.017 \\
\hline 1997 & -8.357 & -27.288 & -33.429 & 26.072 & -7.845 \\
\hline 1998 & -6.430 & -30.670 & -35.195 & 16.082 & -17.265 \\
\hline
\end{tabular}

Fonte: BACEN. Elaboração própria.

Dessa forma, com a alienação desses ativos públicos, a gestão FHC pretendia abater 
parcela considerável da dívida líquida do setor público, que representava, em 1994, 26\% do PIB. Essa meta, entretanto, não conseguiu se concretizar, apesar do empenho das autoridades econômicas na condução do processo de privatização de todo o setor de telecomunicações e da quase totalidade da área de distribuição do setor elétrico.

De fato, a dívida líquida total do setor público atingiu, em 1998, o patamar de $38,3 \%$ do PIB resultante da política equivocada de manutenção das altas taxas de juros internas, que acabou exercendo efeito direto sobre o aumento do peso dos juros nos compromissos públicos assumidos.

Completando os objetivos diretamente vinculados à privatização, foi dada especial ênfase à necessidade de participação da iniciativa privada como pré-condição para a retomada dos investimentos, em especial àqueles relacionados à execução de projetos de infra-estrutura, ressaltando, inclusive, os benefícios que essa opção traria à população, em decorrência da eficiência do setor privado na condução dessas atividades econômicas. $\mathrm{O}$ estímulo à modernização da indústria e ao fortalecimento do mercado de capitais, também, engrossou esse coro.

Com isso, pode-se concluir que, durante os anos 90, a privatização tornou-se, oficialmente, a principal política para o setor produtivo estatal que, em associação com outras reformas em curso, completariam o quadro de profundas transformações estruturais, capazes de garantir um novo tipo de inserção internacional para o Brasil e uma nova definição para o Estado nacional.

Durante os próximos parágrafos, tentar-se-á analisar de que maneira esse processo de abertura e internacionalização, vivenciado pela economia brasileira durante a década de 90, afetou o setor elétrico nacional.

\subsection{A reestruturação do setor elétrico e sua regulamentação básica: da Lei $n^{\circ}{ }^{8.631 / 93}$ à Lei $n^{0}$ 9.648/98}

Parece existir um relativo consenso de que o marco do processo de reestruturação do setor elétrico brasileiro tenha se dado, de fato, com a promulgação, em 1993, da Lei 8.631, que, como bem apontaram Pires e Piccinini (1998, p. 40), introduziu três inovações importantes, a saber: a) a eliminação do regime de equalização tarifária; b) a promoção de 
um grande encontro de contas entre as credoras e devedoras do setor; e c) a obrigatoriedade de se estabelecer contratos de suprimento de energia entre as geradoras e as distribuidoras.

No caso da desequalização tarifária, o governo federal pretendia, de um lado, abandonar a prática de remuneração garantida dos $10 \%$ mínimos de retorno sobre os ativos das concessionárias e o nivelamento geográfico das tarifas, que já davam mostras de sua ineficiência, ao estimularem a elevação dos custos setoriais e regionais. De outro, esperava que as concessionárias passassem a definir a correção de seus serviços projetada para refletir seu fluxo de caixa, usando como variável de ajuste os componentes de custo do serviço de cada empresa específica, e não o retorno arbitrário sobre seus ativos, de modo a estabelecer a remuneração do serviço adequado à realidade de cada segmento ou empresa da cadeia produtiva do setor.

Com isso, dá-se início ao processo de desverticalização do setor elétrico brasileiro, reforçado, inclusive, com o estabelecimento de dois conjuntos de tarifas, conforme coloca Ferreira (2000, p. 195): a) a tarifa de suprimento, como sendo o índice de atacado cobrado por uma geradora de energia elétrica na venda para as empresas de distribuição, com a inclusão do custo de utilização da linha de transmissão; e b) a tarifa de fornecimento, revelando o índice cobrado pelas empresas de distribuição do consumidor final, variando de acordo com cada classe de consumo e em relação à quantidade de energia consumida.

Completando a nova política tarifária definida para o setor, em seu artigo 11, foi prevista a possibilidade de se contemplar, nas propostas iniciais, programas graduais de recuperação das tarifas, "atendendo as diversidades econômicas e sociais das áreas de concessão", e "sem prejuízo dos reajustes periódicos".

A mesma legislação promoveu, também, como lembra Pires e Piccinini (1998, p. 42), “um amplo encontro contábil das contas a receber e a pagar das empresas do setor elétrico, eliminado os créditos das geradoras federais junto às distribuidoras estaduais. $\mathrm{O}$ Tesouro Nacional absorveu cerca de US\$ 20 bilhões relativos às dívidas das empresas nesse encontro de contas" ${ }^{\prime 6}$.

\footnotetext{
${ }^{66}$ O trabalho de Lima (1996, p. 198/199) busca representar os fluxos previstos no encontro das contas do setor elétrico, a partir da Lei 8.361/93 e do valor contábil da CRC aprovado pelo poder concedente (DAEE) para cada uma das concessionárias.
} 
Quanto às relações contratuais, a lei estabeleceu a obrigatoriedade de contratos de fornecimento entre empresas geradoras e distribuidoras, através da fixação das demandas de potência e de energia de curto, médio e longo prazos, explicitando, ainda, as quantidades, os preços e as regras de intercâmbio de energia entre as empresas envolvidas.

Além disso, a Lei 8.631/93, em seu Artigo 13, passou a exigir, de todas as concessionárias de serviço público de distribuição de energia elétrica, a criação, no âmbito da sua área de atuação, dos Conselhos de Consumidores. De caráter consultivo, composto por igual número de representantes das principais classes tarifárias, estaria voltado para orientação, análise e avaliação das questões ligadas ao fornecimento, tarifas e adequação dos serviços prestados ao consumidor final.

Apesar do governo federal ter concebido, adequadamente, os princípios que orientaram a legislação, ao introduzir autonomia empresarial na definição dos níveis tarifários e estimular a competitividade e a eficiência econômica das concessionárias, diversos aspectos, listados por Pires e Piccinini (1998, p. 43) e abaixo reproduzidos, comprometeram sua implementação e seus resultados efetivos. São eles:

o DNAEE mostrou-se desaparelhado e sem autonomia para analisar as planilhas de custo das diferentes concessionárias;

- a decisão final sobre os reajustes das tarifas continuou a cargo da equipe econômica, como parte da política de controle da inflação; ${ }^{67}$

- a combinação destes dois fatores impediu a substituição da antiga prática de reajustes uniformes pelo novo critério da Lei 8.631/93, que previa reajustes específicos para cada concessionária de acordo com a evolução de seus custos; ${ }^{68}$

- apesar de as concessionárias terem estabelecidos contratos de suprimento com as geradoras de eletricidade, continuaram a ocorrer atrasos de pagamentos e inadimplência no setor; ${ }^{69}$

- os conselhos de consumidores, que foram criados em cumprimento à Lei 8.631/93, não tiveram definidos claramente os critérios de escolha e as funções dos conselheiros, não trazendo qualquer resultado prático para a defesa dos

\footnotetext{
${ }^{67}$ Por exemplo, a Medida Provisória 482/95, que instituiu o Plano Real, suspendeu, a partir de junho de 1995, os reajustes das tarifas públicas, inclusive setor elétrico, e a Lei 9.096/95, revogou o programa de recuperação tarifária previsto no artigo 11 da Lei 8.631/93.

${ }^{68}$ Os reajustes tarifários homologados pelo DNAEE entre maio de 1993 e maio de 1994 apresentaram grande uniformidade, foram definidos abaixo dos valores reivindicados pelas concessionárias e oscilaram em torno de 3\% acima ou abaixo dos índices inflacionários, após o que foram convertidos em Unidade de Reserva de Valor (URV) [Brunetti e Guerra (1996)].

${ }^{69}$ Por exemplo, em junho de 1996, a CESP e a Eletropaulo deviam respectivamente, US\$ 3 bilhões e US\$ 500 milhões referentes à compra de energia de Itaipu [Gazeta Mercantil (07.06.96)].
} 
consumidores. ${ }^{70}$

Tabela 3.3.

Preços médios de energia para 1995-1998

média mensal de R\$ julho/98 ${ }^{(1)}$

\begin{tabular}{|c|c|c|}
\hline \multirow[b]{2}{*}{ Período } & \multicolumn{2}{|c|}{ Tarifas Selecionadas } \\
\hline & $\begin{array}{l}\text { Residencial }^{(2)} \\
\mathrm{R} \$ / \mathrm{MWh}\end{array}$ & $\begin{array}{c}\text { Industrial }^{(3)} \\
\mathrm{R} \$ / \mathrm{MWh}\end{array}$ \\
\hline 1994-julho & 141,361 & 36,819 \\
\hline 1995-I & 124,065 & 29,646 \\
\hline 1995-II & 118,039 & 28,206 \\
\hline 1995-III & 112,765 & 26,945 \\
\hline 1995-IV & 128,181 & 32,082 \\
\hline 1996-I & 132,511 & 33,789 \\
\hline 1996-II & 129,104 & 32,921 \\
\hline 1996-III & 125,918 & 32,108 \\
\hline 1996-IV & 124,936 & 31,858 \\
\hline 1997-I & 121,355 & 30,945 \\
\hline 1997-II & 129,858 & 33,116 \\
\hline 1997-III & 128,791 & 32,844 \\
\hline 1997-IV & 126,878 & 32,356 \\
\hline 1998-I & 124,737 & 31,810 \\
\hline 1998-II & 124,393 & 31,723 \\
\hline 1998-III & 124,689 & 31,798 \\
\hline 1998-IV & 124,559 & 31,765 \\
\hline
\end{tabular}

(1) Deflator IGP-DI; (2) Tarifa CESP (R\$ por MWh), para categoria de consumo residencial na faixa de 101 a $200 \mathrm{KWh}$ (sem ICMS) e (3) Tarifa CF (R\$ por MWh), para categoria A2, intensidade de 88 a $138 \mathrm{kv}$ (sem ICMS)

Fonte: extraído de DIESP (1999, p. 40)

A Tabela 3.3. apresenta a evolução dos preços de energia elétrica relativos a duas categorias selecionadas: Residencial e Industrial A2. No caso da tarifa referente à faixa de consumo residencial verifica-se que o valor alcançado, por exemplo, ao final de 1998, revela uma queda de quase $12 \%$ em relação ao valor de julho de 1994 . Da mesma forma, a tarifa industrial A2 registrou, no mesmo período, uma redução próxima a 14\%, na comparação com julho de 1994.

Esse comportamento reforça os argumentos apontados anteriormente, evidenciando que a orientação da política macroeconômica e a fragilidade institucional do setor reveladas no desaparelhamento do DNAEE e nos vícios comportamentais das concessionárias, foram os principais motivos que comprometeram a efetiva implementação dos objetivos centrais da lei em questão.

\footnotetext{
${ }^{70}$ Por exemplo, os conselhos criados pela CERJ e pela Light não tiveram qualquer atuação relevante nas discussões sobre a baixa qualidade dos serviços prestados no Estado do Rio de Janeiro, particularmente no verão de 1998.
} 
Em dezembro de 1993, entretanto, outro importante passo foi dado no sentido de dar continuidade ao processo de desverticalização do setor. Através do Decreto $n^{\circ}$ 1.009/93, foi criado o Sistema Nacional de Transmissão de Energia Elétrica - SINTREL, composto pelos sistemas de transmissão de propriedade das empresas controladas pela Eletrobrás, que integram a malha básica dos sistemas interligados das regiões Sul/Sudeste/Centro Oeste e Norte/Nordeste. Com essa medida, o governo federal distingue as áreas de transmissão do conjunto do sistema, mas preserva sua administração nas mãos da Eletrobrás, ao mesmo tempo em que sinaliza a necessidade de se estabelecer os instrumentos jurídicos capazes de definir as condições de acesso e a utilização do SINTREL, inclusive para os autoprodutores $^{71}$.

Completando a legislação anterior, em abril de 1994, foi publicada a Portaria $\mathrm{n}^{\circ}$ 337, que definiu os critérios para a formação de consórcios entre concessionárias e autoprodutores, visando à exploração de aproveitamentos, assegurando o livre acesso à malha federal de transmissão - SINTREL, propiciando a possibilidade de competição na geração e definindo as condições de comercialização.

Dessa forma, embora o processo de reestruturação do setor elétrico brasileiro tenha começado a materializar-se em 1993, quando as regras acima mencionadas introduziram modificações importantes em seu funcionamento, é, de fato, a partir de 1995, que esse processo se acelera.

Com a promulgação de vários documentos legais, a introdução dos ativos de geração pertencentes às empresas subsidiárias da Eletrobrás no Programa Nacional de Desestatização (PND) e a aprovação, pelas assembléias legislativas estaduais, de Programas Estaduais de Desestatização (PED), que alinhados ao Programa de Estímulo à Privatização Estadual (PEPE), do BNDES, permitiam a antecipação de recursos aos Estados caucionados pelas ações ordinárias de empresas de eletricidade e/ou outros serviços públicos, é estabelecido um novo ambiente, visando induzir e dinamizar os fluxos de negócios entre os diversos agentes, bem como amenizar a crise fiscal de diversos Estados

\footnotetext{
${ }^{71}$ O Decreto 1009/93, em seu artigo $3^{\circ}$, parágrafo único, define autoprodutor como sendo a pessoa jurídica pública ou privada, que esteja capacitada a produzir individualmente, ou de forma consorciada, energia elétrica para uso próprio, fornecendo o excedente ao concessionário de serviço público. Conforme será abordado no próximo capítulo, com essa definição amplia-se o conceito de autoprodutor, focando na possibilidade de atrair parceiros privados para o segmento de geração.
} 
da Federação.

Dentre o conjunto de medidas, que sinalizam a decisão política de permitir a participação da iniciativa privada em novas áreas, merece atenção especial a aprovação da Lei de Concessões, no início de 1995, que define o regime de concessão e permissão da prestação de serviços públicos, excluídos apenas rádio e televisão ${ }^{72}$. Dentre os principais pontos, estabelecidos pela Lei $8.987 / 95$, podem ser destacados:

a) a obrigatoriedade de prévia licitação para outorga de concessão de serviço público, inclusive subconcessão;

b) a exigência de prazo determinado para a concessão renovável por licitação;

c) o oferecimento, pelas concessionárias de serviço público, em garantia a contratos de financiamento, dos direitos emergentes da concessão, até o limite que não comprometa a operacionalização e a continuidade da prestação do serviço;

d) os critérios para julgamento das licitações de concessão, fixando-se a tarifa do serviço público a ser prestado, que passou a ser definida em contrato, e selecionando-se o maior valor ofertado, para pagamento ao poder concedente, pela outorga da concessão;

e) as tarifas poderão ser objeto da reajuste (associado à perda de valor da moeda e à ocorrência de fatos previsíveis não computados no equilíbrio econômico-financeiro inicial do contrato) e de revisão (pela ocorrência de eventos de determinação estatal imprevistos e imprevisíveis);

f) a possibilidade de receitas alternativas, complementares, acessórias ou de projetos associados, com vistas a fortalecer a modicidade das tarifas, estabelecidas no edital de licitação, pelo poder concedente, a favor da concessionária;

g) a possibilidade de escolha de foro e de um modo amigável de solução de conflitos de interesse relativos ao contrato de concessão; e

h) o princípio de fiscalização, pelo usuário, do serviço público executado.

\footnotetext{
${ }^{72}$ A Lei $n^{\circ} 8.987$, de 13/02/95, originou-se no Senado Federal, de autoria do então senador Fernando Henrique Cardoso, e foi aprovada após realizadas modificações pela Câmara Federal.
} 
Na verdade, a aprovação dessa lei só foi possível porque o governo aceitou dar um tratamento diferenciado ao setor elétrico. Uma Medida Provisória específica (MP 890, de 13/02/95), transformada posteriormente na Lei 9.074, de 07/07/95, determinou que as atuais empresas geradoras de energia poderiam ter prorrogados, em até vinte anos, os prazos de suas concessões. Já no caso das obras paralisadas ou atrasadas, a MP impôs a obrigatoriedade de que pelo menos $1 / 3$ do capital seja privado, cancelando as concessões com obras não iniciadas. Foram fixados ainda prazos e condições de concessão para geração, transmissão e distribuição de energia elétrica e garantiu a opção, por parte dos grandes consumidores, de contratar seu fornecimento, em todo ou em parte, com o produtor independente de energia elétrica, Autorizou também a constituição de consórcios de geração de energia elétrica para fins de serviço público, para uso exclusivo dos consorciados, e/ou para produção independente.

A lei federal, por sua vez, definiu ainda que as concessões realizadas sem licitação, após a Constituição de 1988, fossem canceladas, podendo ser submetidas à nova licitação. O mesmo procedimento deveria ser utilizado para as concessões outorgadas antes de 1988, e cujas obras ou serviços não tenham sido iniciados ou se encontrem paralisados. Nos demais casos, as concessões permaneceriam válidas até o vencimento.

Como resultado da aprovação desta lei de concessões, o governo federal pôde revogar imediatamente a concessão de 33 usinas hidrelétricas, além de todas as concessões outorgadas a Furnas para o aproveitamento do Rio Tocantins, abrindo espaço para novas licitações com a perspectiva de entrada de grupos privados.

Em setembro de $1996^{73}$, o Executivo regulamentou as atividades do produtor independente e do autoprodutor de energia, também previstas na Lei 9.074/95, assegurando a esses produtores o acesso às redes de transmissão e distribuição existentes. Ficaram dispensados de concessão ou autorização o aproveitamento de potencial hidráulico inferior a $1.000 \mathrm{~kW}$ e a implantação de usina termelétrica de potencial igual ou inferior a $5.000 \mathrm{~kW}$.

A regulamentação estabeleceu, ainda, a sistemática de concessão precedida de licitação para o aproveitamento de potencial hidráulico superior a $1.000 \mathrm{~kW}$ por produtor independente e $10.000 \mathrm{~kW}$ por autoprodutor. A sistemática de simples autorização ficou

\footnotetext{
$\left({ }^{73}\right)$ Decreto $n^{\circ} 2.003$, de 11/09/96.
} 
para:

a) implantação de usina termelétrica de potência superior a $5.000 \mathrm{~kW}$ para autoprodutor e produtor independente; e

b) aproveitamento potencial hidráulico superior a $1.000 \mathrm{~kW}$ e igual ou inferior a $10.000 \mathrm{kw}$ por autoprodutor.

Com essa regulamentação, o governo federal buscava abrir, rapidamente, um amplo leque de opções para investimentos no setor, principalmente em termelétricas.

Em dezembro de 1996, como forma de adequar o modelo institucional ao movimento de reestruturação em curso no setor, foi promulgada a Lei 9.427/96, que, além de criar a Agência Nacional de Energia Elétrica (ANEEL), órgão regulador do setor em nível federal, reordenou as áreas de negócios do setor em: produção de energia (geração); transporte nas tensões mais altas (transmissão); transporte com o específico objetivo de atendimento a consumidores finais (distribuição); e vendas no varejo, com a função de medir e faturar os consumidores finais (comercialização). Essa alteração desverticalizou os dois negócios setoriais existentes, a saber: suprimento (venda ao atacado) e fornecimento (venda no varejo).

Constituída sob a forma de autarquia especial, vinculada ao Ministério das Minas e Energia, a ANEEL assume as responsabilidades do DNAEE, consolidando, assim, o novo aparato regulatório para o setor elétrico nacional necessário ao acompanhamento do desempenho dos serviços realizados na área, de maneira "a proporcionar as condições favoráveis para que o desenvolvimento do mercado de energia elétrica ocorra com equilíbrio entre os agentes e em benefício da sociedade" ${ }^{\text {, }}$.

Assim, a ANEEL passa a exercer as seguintes funções e tarefas:

a) regular e fiscalizar a produção, transmissão, distribuição e comercialização de energia elétrica, em conformidade com as políticas e diretrizes do governo federal, promovendo a articulação com os Estados e Distrito Federal, para aproveitamento energético dos cursos de água e compatibilização com a política nacional de recursos hídricos;

\footnotetext{
74 Conforme explicitado na Resolução $n^{0}$ 296, de 11/09/1998, que estabelece os procedimentos para a descentralização de atividades complementares da ANEEL para os Estados e o Distrito Federal.
} 
b) promover, também, as licitações destinadas à contratação de concessionárias de serviço público para produção, transmissão e distribuição de energia elétrica e para a outorga de concessão para aproveitamento de potenciais hidráulicos; e

c) fixar os critérios para cálculo do preço de transporte, assegurando aos fornecedores e respectivos consumidores livres acesso aos sistemas de distribuição e transmissão de concessionário e permissionários de serviço público, mediante ressarcimento do custo de transporte envolvido.

De forma a preservar a autonomia de sua gestão, inclusive financeira, conforme protagonizado pelas boas práticas de regulação econômica destacadas no primeiro capítulo, foi criada a Taxa de Fiscalização dos Serviços de Energia Elétrica ${ }^{75}$, com a expectativa de que, no prazo máximo de três anos, a ANEEL dispensasse recursos ordinários do Tesouro Nacional, na previsão de suas receitas.

Em meados de 1996, o Ministério das Minas e Energia e a Eletrobrás contrataram um consórcio consultor liderado pela empresa Coopers \& Lybrand, com o objetivo de: $1^{\circ}$ ) sugerir um novo desenho para o mercado elétrico, capaz de estabelecer regras visando preservar o espaço competitivo nas áreas de geração e comercialização de energia, e as condições de atuação nas áreas onde ainda predominam monopólios (transmissão e distribuição de energia); e $2^{\circ}$ ) propor uma nova organização institucional, particularmente no que se refere às empresas e instituições vinculadas ao governo federal.

O trabalho, conhecido pela denominação de "Projeto de Reestruturação do Setor Elétrico Brasileiro", contemplou quatro áreas específicas de tratamento:

a) o projeto de novos arranjos mercantis para o setor, abarcando a compra e venda de energia em grosso, acesso à redes de transmissão e distribuição e mecanismos para assegurar planejamento e expansão do setor, especialmente no que se refere ao desenvolvimento ótimo de novos potenciais hidrelétricos;

\footnotetext{
${ }^{75}$ Em seu artigo 12, a lei estabelece que a Taxa de Fiscalização, equivalente a $0,5 \%$ do valor do benefício econômico anual auferido pelo concessionário, permissionário ou autorizado, será diferenciada em função da modalidade e proporcional ao porte do serviço concedido, permitido ou autorizado, aí incluída a produção independente de energia elétrica e a autoprodução de energia.
} 
b) as medidas jurídicas e regulamentares necessárias para permitir a reforma do setor, inclusive ajustes ao quadro jurídico e regulamentar existente referente a concessões, regulamentação econômica de monopólios naturais, regulamentação para facilitar a concorrência e padrões técnicos e de atendimento ao cliente;

c) as mudanças institucionais necessárias no governo e no setor para complementar os arranjos mercantis e o quadro regulamentar propostos. Estas mudanças incluem mudança do foco de responsabilidade do Ministério, estabelecimento de um Órgão Regulador Independente (a ANEEL), revisões do papel da Eletrobrás e mudanças estruturais das empresas do setor; e

d) o trabalho sobre financiamento do setor, alocação de riscos e nível de retorno das diversas atividades.

Concluído em junho de 1997, o estudo buscou desenhar um aparato regulatório/institucional, bem como um modelo mercantil e de financiamento para o setor elétrico brasileiro. A reestruturação proposta, que seguia o modelo implementado em outros países, a partir da experiência inglesa ${ }^{76}$, buscava atingir dois objetivos centrais: de um lado, manter as funções política e de regulamentação nas mãos do Governo e, de outro, transferir, ao setor privado, a responsabilidade sobre operação e investimento anteriormente executadas pelo setor público.

No caso específico das mudanças institucionais, o relatório de consolidação dos trabalhos de consultoria acabou por sinalizar dois pontos essenciais, quais sejam:

$1^{\circ}$ ) definir papéis e responsabilidades do governo, especialmente nas áreas sob sua responsabilidade direta, de forma a distinguir os papéis do governo como definidor de políticas, regulador, bem como proprietário dos segmentos do setor que não forem privatizados; e

$2^{\circ}$ ) reorganizar o DNAEE para que se transforme no novo Órgão Regulador do setor, a ANEEL, estabelecida de acordo com a Lei 9.427, de 03 de dezembro de 1996.

Das recomendações sobre os papéis e responsabilidades institucionais, sintetizadas

\footnotetext{
${ }^{76}$ O Anexo I “As experiências institucionais e regulatórias de países selecionados”, faz um breve síntese dos modelos de reestruturação do setor elétrico inglês, norueguês e argentino.
} 
no Relatório Consolidado da Coopers \& Lybrand, destacam-se:

a) ANEEL: uma das principais questões reforçada por diversas vezes no estudo da Consultoria refere-se à necessidade de se assegurar a imparcialidade e independência dessa nova agência reguladora, de forma a permitir o tratamento eficaz das questões decorrentes da participação privada e da concorrência no setor. O estudo recomenda, ainda, que a missão da ANEEL seja assegurar o suprimento adequado de energia elétrica, confiável e a preço razoável a consumidores existentes e novos, através da regulamentação de preços, quando houver monopólio em níveis condizentes com concessionárias eficientes e financeiramente viáveis, e através do incentivo à concorrência, sempre que este for um mecanismo prático e eficiente. Na verdade, o Sumário Executivo da Consultoria coloca que a abrangência, estilo e forma do trabalho de regulamentação da ANEEL devem se basear nos princípios de eficiência, eqüidade, praticidade, transparência e redução do risco regulatório ${ }^{77}$. Ainda em relação à ANEEL, o estudo reforça que sua Diretoria funcione como órgão colegiado, sendo cada diretor responsável por sua área, confirmando as premissas estabelecidas na Lei 9.427/96;

b) Ministério das Minas e Energia e Secretaria Nacional de Energia (MME/SEN): deveriam manter a função de formuladores de política energética, integrada às políticas de outros Ministérios, bem como estabelecer um processo claro de monitoração e prevenção de comportamento anti-competitivo, definindo responsabilidades entre as várias entidades envolvidas (ANEEL, CADE, SDE e SEAE) e especificando suas funções individuais. Nessa linha, o estudo sugeriu, por exemplo, que caberia à ANEEL a responsabilidade de investigar os problemas potenciais e ao CADE a tarefa de examinar as provas e decidir as medidas a serem tomadas;

c) Eletrobrás: o trabalho da consultoria analisou as tarefas executadas pela Eletrobrás, avaliando como tais funções e responsabilidades deveriam ser reagrupadas, dado o novo modelo mercantil e o quadro institucional propostos. Os resultados dessa análise foram a identificação de cinco papéis específicos, a serem combinados em três entidades setoriais, a saber ${ }^{78}$ :

\footnotetext{
${ }_{77}^{77}$ Coopers \& Lybrand (1997: 30).

78 Uma descrição mais detalhada desses papéis específicos poderá ser encontrada em Coopers \& Lybrand (1997: 31-32).
} 
$\left.1^{\circ}\right)$ papel de holding Federal e de Agente Financeiro Setorial: a Eletrobrás, controlada pelo Governo Federal, deveria continuar atuando como empresa holding, com participação acionária minoritária relevante de $25 \%$, e investindo capital próprio em novos projetos que fossem importantes sob um ponto de vista político-social (forte elemento de interesse público), complementando os recursos do setor privado. A Eletrobrás também administraria a RGR e seria financiada por dividendos de suas subsidiárias remanescentes e das participações não vendidas na privatização, comissões e margens sobre suas atividades de crédito. $\mathrm{O}$ estudo destaca ainda que a Eletrobrás seria o veículo com maior credibilidade para prestar indenizações contra alterações legislativas ou mudanças das condições ambientais que afetem os custos de projetos específicos, e não de projetos em geral. No longo prazo, o estudo sugere reavaliar a localização do Agente Financeiro do Setor, cujas opções poderiam ser: a permanência na Eletrobrás; a transferência ao BNDES ou tornar-se um fundo ou empresa independente;

$\left.2^{\circ}\right)$ papel de Operador Independente do Sistema (OIS): essa função seria assumida por uma nova identidade de direito privado sem fins lucrativos, o Operador Nacional de Sistema (ONS). Constituída através de cinco classes diferentes de ações com direito a voto, correspondendo aos principais interessados em suas atividades (geradores, distribuidores, empresas de transmissão, grandes clientes e participação pública), o ONS seria o responsável pela administração e pela operacionalização do sistema de geração e da sinalização dos investimentos de transmissão ao longo de um horizonte de tempo de até cinco anos. Dessa maneira, o ONS deveria substituir as tarefas anteriormente assumidas pelo Grupo Coordenador para Operação Interligada (GCOI), área da Eletrobrás que planejava e coordenava a operação de curto e longo prazo do sistema elétrico nacional, passando a executar o controle da rede de transmissão, a cobrança dos usuários pelo uso da rede de transmissão e alocação das receitas das empresas de transmissão, programação e despacho das usinas de geração, determinação da energia firme de cada usina e do sistema como um todo; e 
$3^{\circ}$ ) papéis de Planejador Indicativo e de Prestador de Serviços do Setor seriam combinados, segundo a empresa de consultoria, em um "Instituto de Desenvolvimento e Prestação de Serviços do Setor Elétrico", que seria também uma organização híbrida, com responsabilidades tanto públicas quanto privadas. Pela proposta o mesmo seria estabelecido como entidade de direito privado sem fins lucrativos, com uma estrutura de votação semelhante à do ONS. Neste caso, os direitos especiais de voto detidos pelo MME lhe dariam o poder de indicar o Presidente do Conselho e nomear um Comitê de Planejamento composto de concessionárias de Distribuição e Comercialização, e do Fórum de Secretários Estaduais de Energia, refletindo o fato de que a função de planejamento tem por objetivo atender aos interesses privados destas concessionárias (e não os dos geradores). $\mathrm{O}$ custeio das atividades viria do pagamento por serviços prestados, bem como de contribuições de seus membros, feitas como condição de seus contratos de concessão. Com esta opção de modelo seria substituído, também, o Grupo Coordenador do Planejamento da Expansão do Sistema Elétrico (GCPS), área da Eletrobrás responsável, principalmente, pelo planejamento da expansão da geração e transmissão, pelo Planejador Indicativo. Ademais, pela proposta este deveria assumir apenas um caráter indicativo e não determinístico, uma vez que o modelo pressupõe o desenvolvimento da concorrência.

d) BNDES: nessa nova estrutura, a Consultoria sugere que, a longo prazo, o BNDES assuma todos os aspectos de "banco" exercidos anteriormente pela Eletrobrás. Assim o BNDES ofereceria empréstimos, linhas de crédito e garantias para projetos adequados. O estudo recomenda também que o BNDES deveria considerar um compartilhamento de riscos com o setor privado em um grande número de áreas. No caso de custos de construção de hidrelétricas, por exemplo, a Coopers \& Lybrand sugere que o BNDES deveria emprestar recursos para financiar estudos de viabilidade de boa qualidade, a serem pagos durante o fechamento do contrato financeiro, caso o projeto continue; e

e) Órgãos Reguladores Estaduais: contribuiriam para estabelecer novas maneiras de realizar a fiscalização e delegação de tarefas regulamentares nos estados, em harmonia 
com as respectivas Secretarias de Energia, com flexibilidade para que os Estados lidem com questões locais, tais como atendimento a reclamações de consumidores que não possam ser solucionadas diretamente pela empresa ou através do PROCON estadual, devolução de reclamações à ANEEL sob circunstâncias predeterminadas, prestação de apoio local aos Conselhos de Consumidores e prestação à ANEEL de informações padronizadas como parte do processo de avaliação.

Quanto ao modelo mercantil, a principal mudança recomendada nos estudos da consultoria foi a criação do Mercado Atacadista de Energia - $\mathrm{MAE}^{79}$, que, seguindo a orientação estabelecida em outras experiências internacionais de liberalização do comércio de energia, foi instituído com a tarefa central de permitir a livre negociação de toda a energia da cada sistema interligado. Assim, a cada período, o mercado livre definiria um preço normativo, com base no custo marginal da energia no sistema, a ser utilizado, como referência, em dois tipos de transações: a) aquisição de blocos de energia, no curto prazo, conhecido como mercado spot, a partir das disponibilidades ofertadas pelos geradores; e b) contratos bilaterais, de longo prazo, entre compradores e vendedores de energia.

Esse mecanismo buscava estabelecer um mercado em que, geradores e empresas distribuidoras e comercializadoras pudessem negociar sua energia não-contratada, criando, ainda, um ambiente multilateral em que comercializadores pudessem comprar de quaisquer geradores e estes vender a quaisquer comercializadores ${ }^{80}$.

Cumpre lembrar, ainda, que a definição da tarifa de energia, negociada nesse mercado, ficaria a cargo do ONS, que, conforme visto anteriormente, ao assumir a função do GCOI, da Eletrobrás, torna-se o responsável pela operacionalização, programação e despacho da energia, além de administrar, também, todos os ativos de transmissão pertencentes às empresas geradoras e de distribuição, de maneira a assegurar a otimização do sistema. Assim, o ONS, na parte final do planejamento operacional, a partir da disponibilidade declarada pelos geradores, passaria a estabelecer um programa de

\footnotetext{
${ }^{79} \mathrm{O}$ relatório da Coopers \& Lybrand previa a celebração de um Acordo de Mercado, com o compromisso de participar do MAE (ou nele estar representado) todos os geradores com capacidade instalada igual ou superior a $50 \mathrm{MW}$, todos os varejistas (distribuidoras e comercializadoras) com carga anual igual ou superior a 100 $\mathrm{GWh}$ e todos os grandes consumidores com demanda acima de $10 \mathrm{MW}$. Ademais, os blocos de energia comercializados entre eles seriam alvo de contratos financeiros - Contratos do Mercado de Atacado de Energia Elétrica (CMAE). [Rosa, Tolmasquim e Pires (1998, p. 173)].

${ }^{80}$ Coopers \& Lybrand (1997).
} 
despacho, otimizando, de forma centralizada, o sistema hídrico brasileiro, e refletindo, no preço à vista do MAE, apenas o custo adicional de curto prazo da geração de energia marginal, com pagamento em separado dos custos de transmissão pela empresa de distribuição.

Em suma, como explicita Sauer (2002, p. 145-146), no novo modelo, a criação de um mercado aberto de comercialização de eletricidade seguiria as seguintes condicionantes:

- assegurar um sistema eficiente de transações de eletricidade;

- assegurar a existência de um mercado onde geradores possam vender sua energia e ter seus investimentos remunerados, mesmo sem a existência de um contrato formal de longo prazo;

- ampliar a competição no varejo;

- fornecer sinais firmes e precisos do valor da eletricidade aos geradores e consumidores; e

- ordenar, sob o critério de rentabilidade, as prioridades nos investimentos em novas unidades de geração.

Tais condicionantes, entretanto, não são tão simples de serem asseguradas, pois, como bem colocam Rosa, Tolmasquim, e Pires (1998, p. 173-174),

"este modelo subordina a lógica do mercado à lógica da operação otimizada centralizada. Por isto, estão previstos mecanismos de realocação do risco hidrelétrico, já que deverão existir casos em que o gerador declara uma capacidade " $\mathrm{x}$ " e apenas uma pequena parte dela é despachada pelo ONS para não afetar o despacho ótimo. Em outras palavras, a receita do gerador deverá ser igual à receita equivalente à energia firme que cada gerador colocar em disponibilidade para o sistema - independentemente se a carga for despachada ou não - pois, em caso contrário, o fator de incertezas seria tão alto que se tornaria impossível, por exemplo, privatizar o sistema."

Completando o raciocínio anterior, aos autores colocam, ainda, que, com essa nova sistemática de comercialização de energia, era de se esperar uma grande volatilidade, no curto prazo, nos preços do MAE, uma vez que refletem "o custo de déficit e a capacidade do sistema em proporção à sua demanda. Por exemplo, haverá grande oscilação de preços de curto prazo do MAE entre os anos chuvosos (preços baixos) e os anos de seca (preços altos)".

Dessa forma, grande parte dos especialistas ligados ao setor elétrico, como expressa Ferreira (2000, p. 199), acredita que a maior parcela da energia consumida continuaria 
sendo negociada através de contratos bilaterais, que amenizam a volatilidade de preço experimentada por todos os participantes do mercado, defendendo a estimativa de que apenas $10 \%$ a $15 \%$ de energia seriam negociados no mercado spot.

A partir desse conjunto de informações e tentando implementar os princípios apresentados pela Consultoria Coopers \& Lybrand, em maio de 1998, os formuladores das reformas do setor, publicaram a Lei Federal $\mathrm{n}^{0}$ 9.648, que, além de estabelecer o novo modelo de comercialização de energia elétrica, autorizou o Poder Executivo a promover, com vistas à privatização, a reestruturação da Centrais Elétricas Brasileiras S/A - Eletrobrás e de suas subsidiárias, a saber: Centrais Elétricas Sul do Brasil S/A - Eletrosul; Centrais Elétricas Norte do Brasil S/A - Eletronorte; Cia. Hidroelétrica do São Francisco - CHESF; e Furnas Centrais Elétricas S/A.

No caso dessa reestruturação, a lei sinaliza, em seu artigo 5, a possibilidade de se criar, mediante operações de cisão, fusão, incorporação, redução de capital ou constituição de subsidiárias integrais, as seguintes sociedades:

a) até seis sociedades por ações, a partir da reestruturação da Eletrobrás, que terão por objeto principal deter participação acionária nas sociedades de geração que forem criadas de suas subsidiárias e na de geração relativa à Usina Hidrelétrica de Tucuruí;

b) duas sociedades por ações, a partir da reestruturação da Eletrosul, sendo uma de geração e outra de transmissão de energia elétrica;

c) até três sociedades por ações, a partir da reestruturação de Furnas Centrais Elétricas S/A, tendo duas como objeto social a geração e uma de transmissão de energia elétrica;

d) seis sociedades por ações, a partir da reestruturação da Eletronorte, sendo duas para geração, transmissão e distribuição de energia elétrica, relativamente aos sistemas elétricos isolados de Manaus e Boa Vista, uma para a geração pela Usina Hidrelétrica de Tucuruí, uma para a geração nos sistemas elétricos dos Estado do Acre e Rondônia, uma para a geração nos sistemas elétricos, uma para geração no Estado do Amapá e outra para a transmissão de energia elétrica; e 
e) até três sociedades por ações, a partir da reestruturação da CHESF, tendo até duas como objeto social a geração e outra como objeto a transmissão de energia elétrica.

Com essa medida, delineia-se o aparato legal visando a desverticalização do setor, intensificando-se a tendência a fragmentação das áreas de geração, transmissão e distribuição, em diferentes "negócios", passíveis de serem alienados ou compartilhados com a iniciativa privada. Assim, estariam sendo ultimadas as adequações do processo de reestruturação do setor elétrico brasileiro à tendência internacional, onde prevalece a lógica do mercado, à revelia das diferenças da matriz energética do país, conforme será visto oportunamente.

Completando o modelo, a Lei 9.648/98 definiu, também, as condições de funcionamento do Mercado Atacadista de Energia - MAE, dispondo, inclusive, sobre os "Contratos Iniciais", como forma de se criar uma fase de transição para o mercado de energia elétrica competitivo, seguindo orientação da própria Consultoria Coopers \& Lybrand. Isto porque, com a assinatura desses contratos, entre as geradoras de energia e as empresas de distribuição, estaria sendo resolvido o problema da variação estrutural de custo causada pelos custos de investimentos sem liquidez, e pelas diferenças entre "energia nova" e "energia velha". Como explica Ferreira (2000, p. 200),

"por esse mecanismo, os fornecedores de baixo custo não teriam que racionar a demanda através de aumento de preços e os fornecedores de preço alto não seriam imediatamente forçados a assumir o papel de produtor 'sobressalente', com todas as conseqüências econômicas resultantes."

Dessa forma, embora a legislação tenha estabelecido que, a compra e a venda de energia elétrica entre concessionários, permissionários, autorizados e consumidores livres passarão a ser de livre negociação, foram definidos prazos de transição para seu pleno funcionamento. Assim, a partir do sexto ano (2003), o volume de energia contratada, nos moldes estabelecidos pelos "Contratos Iniciais”, será reduzida em 25\% ao ano, de maneira que a transição para a aquisição de energia no livre mercado, tanto através de contratos bilaterais como no mercado spot, esteja concluída em nove anos (a partir de 2007). No caso das usinas do Norte e Nordeste, a redução gradual começará somente após onze anos ${ }^{81}$.

\footnotetext{
${ }^{81}$ Cumpre ressaltar que a Consultoria Coopers \& Lybrand previu, em seus estudos, um período de transição maior, sendo de 20 anos para as Usinas do Norte/Nordeste e de 15 anos para as demais. A legislação não se
} 
Registre-se, ainda, que o artigo 13, legitimou o Operador Nacional do Sistema Elétrico - ONS, destacando, em seu parágrafo único, suas principais atribuições, a saber:

a) o planejamento e a programação da operação e o despacho centralizado da geração, com vistas à otimização dos sistemas eletroenergéticos interligados;

b) a supervisão e a coordenação dos centros de operação de sistemas elétricos;

c) a supervisão e o controle da operação dos sistemas eletroenergéticos nacionais interligados e das interligações internacionais;

d) a contratação e a administração de serviços de transmissão de energia elétrica e respectivas condições de acesso, bem como dos serviços ancilares;

e) propor à ANEEL as ampliações das instalações da rede básica de transmissão, bem como os reforços dos sistemas existentes, a serem licitados ou autorizados;

f) a definição de regras para a operação das instalações de transmissão da rede básica dos sistemas elétricos interligados, a serem aprovadas pela ANEEL.

Em paralelo ao ambiente de reestruturação do setor elétrico brasileiro, vai avançando, também, o processo de privatização dos ativos de energia elétrica. Com a venda da Escelsa, em julho de 1995, o governo federal conseguiu alienar a primeira empresa desse setor, no âmbito do PND.

O Consórcio Parcel, formado pela empresa Iven S.A. - constituída pelo Banco Pactual (seu idealizador) e outras instituições - em associação à GTD Participações, representantes de 11 fundos de pensão, foi montado para impedir que o ágio do leilão fosse muito alto. Assim, a primeira, que já controlava cerca de $20 \%$ da Escelsa ${ }^{82}$, passou a deter $45 \%$ do capital total, cabendo $25 \%$ à GTD. Os novos proprietários adquiriram a Escelsa pelo valor de $\mathrm{R} \$ 385,7$ milhões (15,7\% acima do preço mínimo definido em edital), pagando $67 \%$ em à vista e o restante em dívidas públicas. Estes recursos arrecadados tiveram a finalidade de abater dívidas assumidas pela Eletrobrás no exterior e avalizadas

aplica, entretanto, para a comercialização de energia elétrica gerada pela Itaipu Binacional e pela Eletrobrás Termonuclear S/A - Eletronuclear.

${ }^{82}$ Vale lembrar que em 1995, quando o governo do Espírito Santo optou por vender as ações relativas à sua participação na Escelsa, iniciando o processo de alienação desta empresa, a empresa Iven S.A., formada com o propósito central de atuar nas aquisições do setor elétrico, comprou os $20 \%$ do capital total que foram postos à venda. 
pelo Tesouro. Vale a pena registrar que o governo optou por reter $14,7 \%$ do capital total da empresa para serem postos à venda posteriormente, de forma a valorizar essa parcela das ações. Ademais, foram reservados aos empregados $7,7 \%$ do capital total da empresa.

No caso da privatização da Light, o primeiro passo deu-se em 29 de janeiro de 1996, quando a Assembléia de Acionistas aprovou a cisão da empresa em Light Serviços de Eletricidade S.A. e Light Participações S.A. Enquanto a primeira foi criada com o objetivo de ser alienada, a segunda absorveu os direitos, créditos e obrigações relativos à Eletropaulo. Com esta solução, delineada com a inclusão da Light no PND, foi possível realizar a privatização da Light Serviços, em maio de 1996.

Representando um dos maiores leilões realizados no país, pois envolveu a habilitação de 27 participantes nacionais e 13 estrangeiros. Apesar da inexistência de comprador para a totalidade das ações ofertadas, o BNDES esperava disputa dado o interesse do consórcio, aparentemente formado entre a Chilectra (empresa do setor elétrico chileno) e fundos de pensão nacionais, e a estatal francesa Electricité de France (EDF) em associação com empresas norte-americanas. Um dia antes, contudo, a Chilectra desistiu, dada a insegurança dos fundos de pensão, permitindo que, pelo preço mínimo, o controle acionário da empresa fosse transferido, cabendo à estatal francesa EDF em associação com as empresas norte-americanas Houston Power Industries e a AES Corporation o maior lote (34,04\% das ações). A participação da BNDESPar (9,14\%) e do Grupo CSN-Vicunha $(7,25 \%)$ foi determinante para que o controle acionário da Light saísse das mãos da Eletrobrás. Com esta operação foram arrecadados R $\$ 2,2$ bilhões, dos quais $\mathrm{R} \$ 1,5$ bilhão em moeda corrente (70\%), e aberta a perspectiva de investimentos e a incorporação de "know-how" pela EDF e seus associados.

Vale a pena destacar que nas condições contratuais da concessão da Light, primeiro contrato estabelecido com uma empresa de distribuição nas mãos da iniciativa privada e o DNAEE, foi definido que após o período de oito anos, o novo órgão regulador (ANEEL) analisaria o desempenho da nova concessionária em relação ao de outras empresas, fazendo alterações na fórmula de reajustes tarifários, como forma a garantir o repasse aos consumidores de eventuais ganhos de eficiência, conseguidos pela empresa. A fórmula de price cap $(\mathrm{P}-X)$, utilizada em várias experiências internacionais e descrita no item 1.2.2.3. 
do presente trabalho, passa a tomar forma no caso brasileiro ${ }^{83}$.

A partir de 1995, com a posse dos novos governadores, são lançados os Programas Estaduais de Desestatização (PED), com ênfase nas empresas elétricas, particularmente no segmento de distribuição, cujo controle acionário encontra-se nas mãos dos governos estaduais. Pressionados por uma carência de recursos para a execução de investimentos públicos em áreas sociais e, dada à caótica situação fiscal em que se encontram os diversos Estados da Federação, o lançamento desses programas torna-se a principal saída encontrada para incrementar suas "austeras" políticas de ajustamento fiscal.

Assim, muitos Estados associam seus PED's ao Programa de Estímulo à Privatização Estadual (PEPE), criado pelo BNDES, e ao Programa de Apoio à Reestruturação e Ajuste Fiscal dos Estados, orientado pelo governo federal, para que, com os recursos do FAT (Fundo de Amparo ao Trabalhador), fossem autorizados empréstimos pelo governo federal, cuja contrapartida foram as ações ordinárias de empresas de eletricidade e/ou de outros serviços públicos, com o monitoramento das privatizações, da grande maioria, pelo próprio $\mathrm{BNDES}^{84}$. Além disso, como ressalta Rosa, Tolmasquim e Pires (1998, p. 162), “o suporte do BNDES à privatização do setor elétrico também se manifestou através de empréstimos a possíveis interessados na compra de capital acionário das estatais privatizadas".

A Tabela 3.4 faz uma síntese das empresas do setor elétrico alienadas entre 1995 a 2000. Registre-se que no total foram transferidas à iniciativa privada vinte empresas de distribuição, quatro de geração, além da efetivação de algumas operações especiais de venda de ações, o que resultou em um volume de recursos da ordem de R \$ 25, 05 bilhões.

\footnotetext{
$\left({ }^{83}\right)$ Após a conclusão do estudo sobre a Reestruturação do Setor Elétrico o período de oito anos utilizado para o caso da Light foi considerado elevado. "Os períodos de controle de preços devem ser longos o suficiente para proporcionar incentivos - o prazo mínimo é, provavelmente, de três anos - mas não longos o bastante para fazer com que seja difícil a previsão de como irão evoluir o fluxo de caixa e a lucratividade". Sumário Executivo (1997, p 23).

${ }^{84}$ Os Estados de São Paulo, Minas Gerais e Rio Grande do Sul optaram por conduzir, de forma independente, seus próprios programas de desestatização, embora mantendo a orientação sinalizada pelo governo federal, particularmente no que se refere à fragmentação das empresas do setor e a constituição de órgãos reguladores.
} 
Tabela 3.4.

Resultados dos leilões de privatização do setor elétrico (1995-2000)

\begin{tabular}{|c|c|c|c|c|c|}
\hline Empresa & $\begin{array}{c}\text { Data da } \\
\text { venda }\end{array}$ & $\begin{array}{l}\text { Valor da Licitação } \\
\text { (US\$ milhões) }\end{array}$ & $\begin{array}{l}\text { Ágio } \\
(\%)\end{array}$ & $\begin{array}{l}\text { \% do } \\
\text { capital } \\
\text { total }\end{array}$ & Grupo que adquiriu controle \\
\hline \multicolumn{6}{|l|}{ Distribuição } \\
\hline Escelsa & $12 / 07 / 95$ & 385 & 11,78 & 50,00 & Iven e GTD (Brasil) \\
\hline Light & $21 / 05 / 96$ & 2.217 & - & 50,44 & $\begin{array}{c}\text { EDF (França), AES (EUA) e } \\
\text { Houston (EUA) }\end{array}$ \\
\hline Cerj & $20 / 11 / 96$ & 588 & 30,27 & 70,26 & $\begin{array}{l}\text { Clilectra/Enersis (Chile) e } \\
\text { EDP (Portugal) }\end{array}$ \\
\hline Coelba & $01 / 07 / 96$ & 1.602 & 77,38 & 62,54 & $\begin{array}{l}\text { Iberdrola (Espanha) e Previ } \\
\text { (Brasil) }\end{array}$ \\
\hline CEEE (COeste) & $01 / 10 / 97$ & 1.372 & 93,55 & 90,91 & AES (EUA) \\
\hline CEEE (Norte-NE) & $21 / 10 / 97$ & 1.487 & 82,62 & 90,75 & $\begin{array}{l}\text { VBC (Brasil), CEA (EUA) e } \\
\text { Previ (Brasil) }\end{array}$ \\
\hline CPFL & $01 / 1197$ & 2.741 & 70,15 & 41,06 & $\begin{array}{l}\text { VBC (Brasil) e Bonnaire } \\
\text { (Brasil) }\end{array}$ \\
\hline Enersul & $19 / 11 / 97$ & 568 & 83,79 & 48,67 & Escelsa \\
\hline Cemat & $27 / 11 / 97$ & 356 & 21,09 & 86,91 & $\begin{array}{l}\text { Grupo Rede/Inepar } \\
\text { (Brasil) }\end{array}$ \\
\hline Energipe & $01 / 12 / 97$ & 525 & 96,05 & 86,42 & $\begin{array}{l}\text { Cataguases-Leopoldina } \\
\text { (Brasil)/CMS (EUA) }\end{array}$ \\
\hline Cosern & $01 / 12 / 97$ & 616 & 73,90 & 85,75 & $\begin{array}{l}\text { Iberdrola (Espanha) e Previ } \\
\text { (Brasil) }\end{array}$ \\
\hline Coelce & $02 / 04 / 98$ & 868 & 27,20 & 53,11 & $\begin{array}{c}\text { Enersis (Chile) e } \\
\text { Endesa (Espanha) }\end{array}$ \\
\hline $\begin{array}{l}\text { Eletropaulo } \\
\text { Metropolitana }\end{array}$ & $15 / 04 / 98$ & 1.776 & - & 29,80 & EDF/AES/Houston \\
\hline Celpa & $01 / 07 / 98$ & 388 & - & 51,26 & $\begin{array}{l}\text { Grupo Rede/Inepar } \\
\text { (Brasil) }\end{array}$ \\
\hline Elektro & $16 / 07 / 98$ & 1.273 & 98,90 & 46,62 & $\begin{array}{c}\text { Enron Brasil } \\
\text { Power Holding }\end{array}$ \\
\hline $\begin{array}{l}\text { Eletropaulo } \\
\text { Bandeirante }\end{array}$ & $17 / 09 / 98$ & 860 & - & 29,80 & CPFL/EDP \\
\hline $\begin{array}{l}\text { Celb-Cia. Em. } \\
\text { BORB. }\end{array}$ & $30 / 11 / 99$ & 45 & - & 75,26 & Energipe \\
\hline Celpe & $17 / 02 / 00$ & 1.004 & - & 99,56 & $\begin{array}{c}\text { ADL Energy (Iberdrola), Previ } \\
\text { e } \\
\text { BB - Banco de Investimento }\end{array}$ \\
\hline Cemar & $15 / 06 / 00$ & 289 & - & 86,25 & Pensylvannia Power \& Light \\
\hline SAELPA & $30 / 11 / 00$ & 185 & - & 74,29 & Energipe \\
\hline \multicolumn{6}{|l|}{ Geração } \\
\hline Cachoeira Dourada & $05 / 09 / 96$ & 663 & 43,49 & 78,88 & Endesa/Enersis \\
\hline Gerasul & $15 / 09 / 96$ & 801 & - & 42,10 & Tractebel (Bélgica) \\
\hline Cesp Paranapanema & $28 / 07 / 99$ & 682 & 90,2 & 38,66 & Duke Energia do Sudeste Ltda \\
\hline Cesp Tietê & $27 / 10 / 99$ & 472 & 29,3 & 38,66 & AES Gerasul \\
\hline $\begin{array}{l}\text { Outras } \\
\text { Operações }\end{array}$ & & 3.284 & & & \\
\hline Empresas Federais & & 3.403 & & & \\
\hline Empresas Estaduais & & 18.358 & & & \\
\hline
\end{tabular}

(a) Incluem US\$ 400 milhões de participação minoritária da Eletrobrás, US\$1,053 bilhão da Cemig, US\$ 413 milhões da Copel, US\$ 74 milhões da CEB, US\$ 154 milhões da Coelba, US\$ 92 milhões da Coelce e US\$1,498 bilhão da Eletropaulo. Fonte: Ferreira (2000, p.210), Indicadores DIESP nº 100, 2004 e BNDES. Elaboração própria. 
Ao explicitar esse conjunto de medidas, buscou-se caracterizar a legislação básica que moldou o movimento de reestruturação do setor elétrico brasileiro, que tem, na origem de sua reforma, a proposta da Consultoria Coopers \& Lybrand, descrita anteriormente. No âmbito de tais mudanças, que como enfatizado seguem o padrão internacional de desverticalização das atividades, com a busca da concorrência e do estabelecimento de um novo aparato regulatório e institucional, transferindo, também, responsabilidades públicas para agentes privados, vários pontos tornaram-se alvos de questionamentos, antes mesmo da conclusão da implantação do novo modelo.

De fato, a crise de racionamento de energia, vivenciada ao longo de 2001, acabou por revelar certas falhas e alguns limites do modelo, levando, inclusive, a reformulação da proposta original. Dessa forma, a seguir será feita uma breve caracterização desses problemas, a partir, principalmente, de algumas identidades institucionais já estabelecidas.

\subsection{Os (des)ajustes da reestruturação do setor elétrico: de 1998 a 2002}

Dentre as principais questões relacionadas ao processo de reestruturação do setor elétrico brasileiro, sintetizadas no item 3.2., merece especial atenção o novo papel desempenho por algumas identidades nacionais, particularmente no que se refere aos arranjos ou vetores de relacionamento institucional existentes entre os órgãos ou instâncias decisórias da esfera política (federal e estadual) e as estruturas regulatórias (também federais e estaduais).

Nessa linha, alguns pontos de conflitos e/ou de equívocos nas atribuições das tarefas parecem existir. Os próximos parágrafos buscam listar alguns desses desajustes, que, de alguma maneira, começaram a ser identificados durante a fase do racionamento de energia.

Seguindo a orientação da própria legislação que criou a ANEEL, está sendo incentivada, por exemplo, a descentralização de suas atividades para os Estados, visando atender os seguintes objetivos básicos: a) aproximar as ações de regulação, fiscalização e mediação dos consumidores e agentes setoriais; b) agilizar os processos de regulação, fiscalização, mediação e outorgas; c) adaptar as ações de regulação, fiscalização e mediação às circunstâncias locais; e d) trazer a solução do problema para o local de origem. 
Assim, os Estados estão criando, por legislação específica, suas agências/comissões, que passam a receber delegação da ANEEL, por meio de celebração de Convênios de Cooperação ${ }^{85}$, semelhante ao firmado com a Comissão de Serviços Públicos de Energia (CSPE) do Estado de São Paulo, primeira agência reguladora estadual a celebrar convênio com a ANEEL, em 15 de abril de 1998, para executar as seguintes diretrizes mínimas:

a) prevenção de potenciais conflitos, por meio de ações e canais que estabeleçam adequado relacionamento entre agentes do setor de energia elétrica, consumidores e demais agentes da sociedade;

b) fiscalização realizada com o caráter de simplicidade e pautada no atendimento às necessidades dos consumidores e no pleno acesso aos serviços de energia elétrica;

c) educação e informação dos agentes e demais envolvidos sobre as políticas, diretrizes e regulamentos do setor de energia elétrica; e

d) transparência e efetividade nas relações com a sociedade.

Segundo informações disponíveis no site da ANEEL, até 2005, dezenove agências haviam sido criadas com a celebração de treze convênios ${ }^{86}$ (ver Figura 3.1). Percebe-se, entretanto, que a preocupação primária da ANEEL a estabelecer tais convênios com os Estados parece ser muito mais a de garantir a presença do regulador federal no local, do que transferir a responsabilidade regulatória para os Estados. Esse tipo de postura pode ser verificado no próprio texto informativo da ANEEL (2005), ao destacar que: "o convênio com as treze agências estaduais contribui para que a ANEEL esteja mais próxima da sociedade e do consumidor, cobrindo quase $70 \%$ da área do país, cerca de $60 \%$ dos consumidores e 38 das 64 concessionárias de distribuição de energia elétrica", conforme se verifica na Tabela 3.5 .

\footnotetext{
${ }^{85}$ Todos os Convênios de Cooperação expressam a mesma preocupação, ou seja, estabelecer cláusulas que têm por objetivo a execução e descentralização pela Agência Estadual de atividades complementares, vinculadas às atribuições da ANEEL, conforme artigo 5º da Resolução ANEEL 296/98.

${ }^{86}$ Em outubro de 2005, a ANEEL suspendeu o Convênio com a ARSAM, em resposta a não observância à manutenção dos requisitos necessários à parceria, no que se refere à autonomia de gestão (processo de escolha, nomeação e mandato dos dirigentes), quando a lei que a criou foi alterada pela Assembléia Legislativa Estadual.
} 


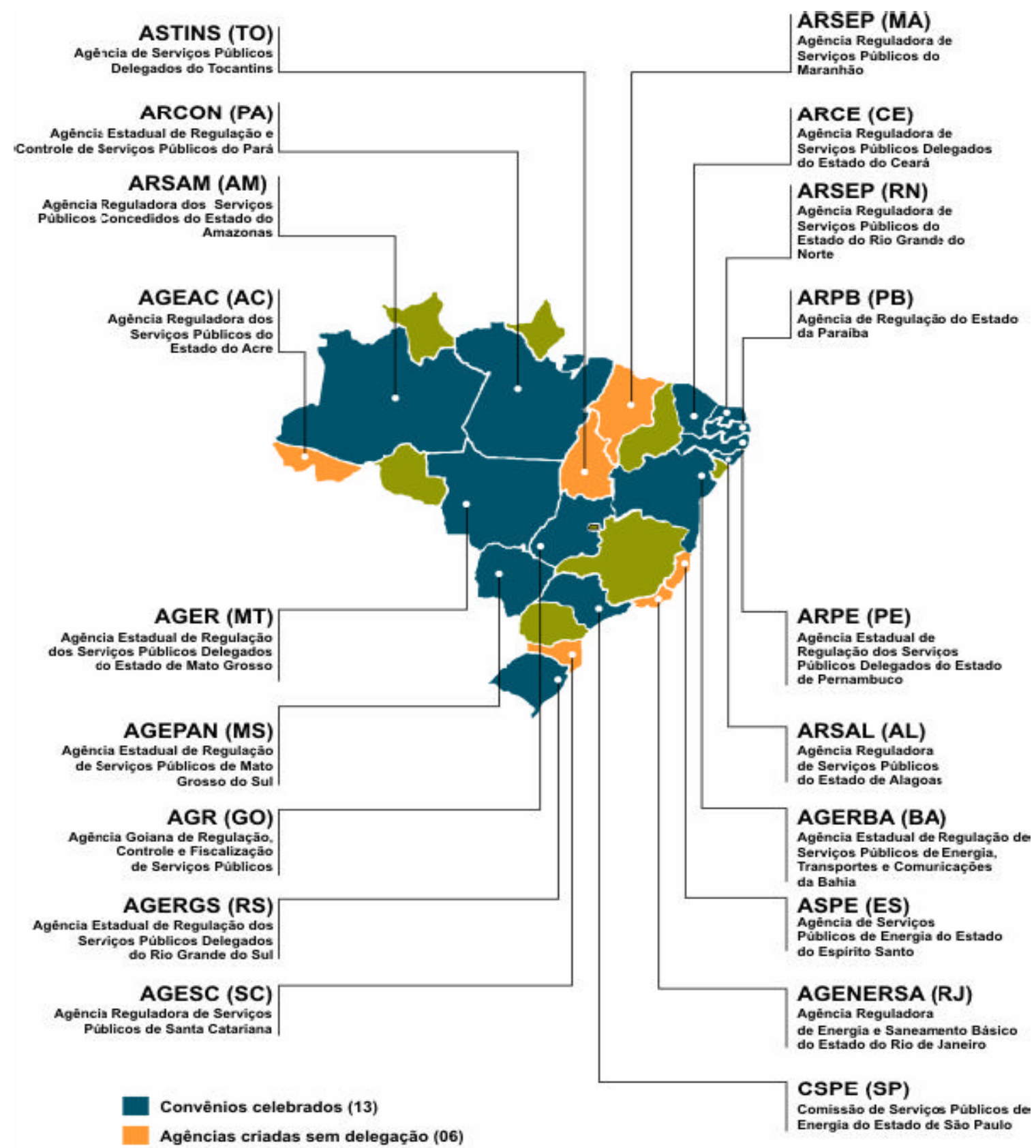

Janeiro/2006

Figura 3.1.

Agências reguladoras criadas no Brasil e Convênios Firmados com a ANEEL Fonte: ANEEL (2005, p. 12). 
Tabela 3.5.

Abrangência das agências estaduais conveniadas

\begin{tabular}{|c|c|c|c|c|}
\hline $\begin{array}{c}\text { Agências } \\
\text { Conveniadas }\end{array}$ & Municípios & $\begin{array}{c}\text { Área Coberta } \\
\left.\mathbf{( k m}^{2}\right)\end{array}$ & $\begin{array}{c}\text { Unidades } \\
\text { Consumidoras }\end{array}$ & Concessionárias \\
\hline 13 & $\begin{array}{c}(54,9 \%) \\
(69,5 \%)\end{array}$ & $\begin{array}{c}(58,8 \%) \\
31 \text { milhões }\end{array}$ & $\begin{array}{c}(60 \%) \\
38\end{array}$ \\
\hline Brasil & $(100 \%)$ & $(100 \%)$ & $(100 \%)$ & $(100 \%)$ \\
& 5.507 & 8,5 milhões & 53 milhões & 64 \\
\hline
\end{tabular}

Fonte: ANEEL (2005, p.13)

Além disso, da simples leitura desses convênios, parece ficar claro o caráter residual do exercício de autonomia regulatória da esfera estadual, revelando, no fundo, uma relação de subordinação entre essas duas esferas regulatórias. Na verdade, seria interessante transferir às agências estaduais a tarefa de fiscalizar, ouvir e implementar políticas setoriais, definidas, previamente, pelos governos estaduais e federais. Para o êxito desta atuação, contudo, deveriam estar claramente estabelecidas as funções a serem executadas pelo órgão regulador (ANEEL) e pelo Ministério das Minas e Energia e pelas Secretarias Estaduais de Energia, na condução da formulação dessas políticas setoriais.

Como visto anteriormente, o estudo da Consultoria Coopers \& Lybrand reforça a necessidade de se manter nas mãos desses últimos órgãos a função de formuladores de política energética, integrada, inclusive, às políticas de outros Ministérios, cabendo aos órgãos reguladores o acompanhamento, de forma independente, de sua execução. Acrescenta, ainda, a necessidade de se estabelecer um processo claro de monitoração e prevenção de comportamento anti-competitivo, entregando à ANEEL a responsabilidade de investigar os problemas potenciais e ao CADE a tarefa de examinar as provas e decidir as medidas a serem tomadas.

Infelizmente, verifica-se que, no caso brasileiro, os compromissos políticopartidários muitas vezes acabaram por prevalecer na orientação da indicação dos ocupantes dos maiores cargos do Ministério das Minas e Energia, levando à sua total omissão em relação aos aspectos técnicos que envolvem a definição da política setorial. Como resultado a esse vácuo de poder, a ANEEL, em especial durante o encaminhamento dos processos de privatização realizados ao final da década de 90, passou a ampliar suas atribuições, 
assumindo tarefas que deveriam ser executadas pelo Ministério das Minas e Energia, como, por exemplo, o papel de poder concedente no âmbito das concessões conduzidas naquele período.

Ademais, na ausência de uma política clara para o setor, torna-se muito mais fácil aceitar o rápido encaminhamento do processo de privatização, uma vez que a tônica fiscal e a eficiência do modelo de reestruturação, defendidas pelas autoridades econômicas, tornamse dominantes.

Outro ponto que merece destaque dentre as distorções do modelo regulatório referese à intervenção do poder executivo quanto à liberação de recursos financeiros conveniados. Apenas para ilustrar, é sabido, por exemplo, que os convênios firmados entre ANEEL às agências/comissões estaduais estabelecem a Taxa de Fiscalização de Serviços de Energia Elétrica - TFSEE, recolhida pelos diferentes agentes do setor de energia elétrica que atuam nos Estados, como sendo base dos recursos financeiros a serem repassados às agências, conforme estabelece a Lei n ${ }^{0}$ 9.427, de 26/12/1996.

Ocorre, entretanto, que, segundo informações divulgadas pela própria ANEEL (2005, p.13), explicitadas na Tabela 3.6, de 1998 a 2002, a agência repassou às agências estaduais recursos da TFSEE, da ordem de R \$ 56,360 milhões, representando um corte de $4,10 \%$ em relação ao valor originalmente previsto para o período, ou seja, $\mathrm{R} \$ 58,733^{87}$.

Tabela 3.6.

Valores previstos e repassados

1998-2002

\begin{tabular}{|c|c|r|}
\hline Ano & $\begin{array}{c}\text { Valores } \\
\text { Previstos } \\
\text { (R\$ milhões) }\end{array}$ & $\begin{array}{c}\text { Valores } \\
\text { Repassados } \\
\text { (R\$ milhões) }\end{array}$ \\
\hline 1998 & 1,046 & 1,046 \\
\hline 1999 & 6,025 & 6,025 \\
\hline 2000 & 11,739 & 11,739 \\
\hline 2001 & 16,367 & 16,079 \\
\hline 2002 & 23,596 & 21,471 \\
\hline Total & $\mathbf{5 8 , 7 7 3}$ & $\mathbf{5 6 , 3 6 0}$ \\
\hline
\end{tabular}

Fonte: ANEEL (2005, p.13)

\footnotetext{
${ }^{87}$ Este repasse sofre uma redução ainda maior, a partir de 2003, conforme será registrado no item 3.5 , em parte em decorrência da própria visão que a gestão do Presidente Luís Inácio Lula da Silva tem sobre a atuação das agências reguladoras, adotando, explicitamente, uma política de esvaziamento.
} 
Com essa atitude, o governo federal parece comprometer a autonomia financeira de tais agências reguladoras, adotando o mesmo tratamento utilizado às demais unidades de administrações públicas, qual seja, subordinando-as à política de contenção de gastos correntes, na busca do superávit primário, apesar de permitir, em contrapartida, que as mesmas tenham liberdade plena na outorga de reajuste tarifário, independentemente da política macroeconômica do Ministério da Fazenda. Em suma, para um país, onde as práticas e os princípios relativos à regulação econômica foram incorporados muito mais em razão de sua adaptação a um modelo de reestruturação copiado de um padrão internacional de desverticalização das atividades do setor, era de se esperar este tipo de distorção.

Em paralelo, deve-se destacar o papel da própria Eletrobrás, nesse novo ambiente. Criada em 1962, com o objetivo de promover estudos e projetos de construção e operação de usinas geradoras, linhas de transmissão e subestações, de propriedade do governo federal, destinadas ao suprimento de energia em todo o território nacional, a Eletrobrás limitou-se, durante a gestão FHC, a acompanhar e incentivar os programas federais ${ }^{88}$, além de exercer suas atividades de holding, enquanto suas subsidiárias CHESF, Eletronorte, Eletronuclear, Eletrosul e Furnas permanecessem em propriedade do governo federal.

$\mathrm{Na}$ verdade, com a entrada do Operador Nacional do Sistema (ONS) e com a criação do Mercado Atacadista de Energia (MAE), a Eletrobrás perdeu a tarefa de controladora central independente dos sistemas interligados, bem como de planejadora integrada de geração, a cargo dessas entidades de direito privado sem fins lucrativos.

Ressalte-se que o ONS foi criado com a função de garantir a programação, a operação, o planejamento operacional e o despacho de carga do sistema. Através de dados recebidos das empresas sobre as afluências hídricas, níveis de reservatórios, disponibilidade de usinas e custos de combustíveis, o ONS, contando com a participação dos diversos agentes envolvidos no setor, planeja a operação do sistema, tentando assegurar a otimização hidro-térmica.

Já o MAE foi estabelecido com a finalidade de realizar todas as transações de compra e venda de energia dos sistemas interligados, não contratados. Todos os fluxos de

\footnotetext{
${ }^{88}$ A Eletrobrás manteve, durante a gestão FHC, a operação dos seguintes programas do governo federal na área de energia elétrica: PROCEL (Programa Nacional de Conservação de Energia Elétrica), Luz no Campo (Programa Nacional de Eletrificação Rural), e RELUZ. Adicionalmente, ainda, é possuidora de $50 \%$ do capital da Itaipu Binacional, além de promover pesquisas no campo da energia elétrica através do CEPEL (Centro de Pesquisa de Energia Elétrica).
} 
energia, no entanto, deveriam ser levados em consideração para a programação e operação ótima do sistema, para o levantamento das perdas e para o cálculo do preço de mercado (spot).

Dessa forma, passamos a conviver com duas novas entidades, o ONS e o MAE, que assumem a responsabilidade de executar as principais funções exercidas, até então, pela Eletrobrás, ou seja, otimizar a operação do despacho de carga do sistema, bem como negociar a energia necessária para suprir os fluxos de energia. Esta mudança institucional eliminou a tarefa de planejar da Eletrobrás transferindo-a, principalmente, para o ONS. A crise de energia, pela qual passou o país em 2001, revelou, contudo, a fragilidade desta estratégia, uma vez que a adoção de um modelo descentralizado, em uma base hidráulica predominante, requer, ao contrário do que se esperava, uma constante coordenação de planejamento, em função das expectativas pluviométricas, para que sua operação seja economicamente eficiente, situação que não ocorreu.

Além disso, ao se apostar na manutenção desse modelo, que tende a intensificar a multiplicidade de agentes, principalmente investidores privados, deve ser redefinida a inserção da Eletrobrás, como empresa pública, de forma a garantir sua capacidade de financiar projetos em geração.

Ademais, com a área de distribuição praticamente privatizada, com $80 \%$ do parque gerador nas mãos do setor público, com uma rede de transmissão incompleta, com a existência de diversos mercados isolados e com uma substancial diversidade de situações regionais, torna-se impraticável adotar uma organização industrial para o setor que seja uniforme em todo o país. Assim, seria aconselhável a adoção de estruturas diferenciadas para cada uma dessas situações com a progressiva convergência para um regime único, na medida em que os mercados se desenvolvam e o mercado nacional esteja plenamente interconectado. Com tais características, parece ficar evidente a necessidade de um órgão planejador, forte e independente, capaz de administrar e coordenar os diferentes agentes envolvidos, tanto em termos operacionais quanto econômico-financeiros. A opção, entretanto, de transferir esta tarefa para o ONS e para o MAE parece ter sido imatura, dada a incapacidade revelada pelos mesmos em assumirem funções tão complexas.

Para finalizar a descrição desta fase do processo de reestruturação, é importante registrar o papel que o Banco Nacional de Desenvolvimento Econômico e Social (BNDES) 
assumiu nesse modelo, enquanto agente financeiro setorial. Embora esta tarefa não tenha sido, de fato, transferida para o BNDES, durante a gestão FHC, sua atuação nesta área, através de condições operacionais dos Programas de Apoio Financeiro a Investimentos em Energia, acabou sendo expressiva, configurando um novo ponto de esvaziamento do papel da Eletrobrás, enquanto Agente Financeiro do Setor, agravada pela sua queda de receita, resultante do processo de privatização.

Em suma, a nova ordem institucional, introduzida com a reestruturação do setor elétrico, parece colocar dois desafios. De um lado, busca a separação de funções e competências entre a esfera política e a regulatória e, de outro lado, tenta, através dessa separação, descentralizar o processo decisório. Essa orientação marca um ponto de radical inflexão, como bem sinalizado por Alveal (1999), ao romper com a trajetória anterior, no qual as funções de política e regulação se concentravam nas empresas ou grupos estatais e, de forma complementar, em órgãos "fiscalizadores", mas não define, de forma responsável, como será realizada a descentralização do processo decisório.

$\mathrm{Na}$ verdade, a orientação dada durante a gestão FHC, ao defender, plenamente, a adoção de programas de privatização, pretendia garantir, aos novos proprietários, a transferência das funções ou responsabilidades das empresas energéticas privatizadas, esvaziando, assim, a autonomia decisória e de planejamento das partes estatais remanescentes. Isto porque, ao transferir para a iniciativa privada, leia-se empresas distribuidoras recém privatizadas, a tarefa de expandir a oferta energética, vinculando seu interesse em contratar energia a longo prazo apenas para atender à demanda energética crescente de seus consumidores, através de contratos bilaterais, o modelo rompe a própria lógica de planejamento anterior, que depositava nas mãos das empresas geradoras a expansão do sistema, que procurava, inclusive, manter o risco de algum racionamento em até $5 \%$.

Desta forma, como os contratos iniciais ${ }^{89}$ cobririam, praticamente, $100 \%$ da previsão de atendimento da demanda por parte das distribuidoras, durante o período 1999-2001, essas parecem não terem tido nenhum tipo de incentivo para promover a expansão da

\footnotetext{
${ }^{89}$ Ressalte-se que, a partir de 1999, todos os contratos entre geradores e distribuidoras foram substituídos pelos Contratos Iniciais. Esses contratos valeriam de 1999 a 2006, reduzindo-se os montantes contratos em $25 \%$ por ano a partir de 2003 .
} 
oferta, nem mesmo para compensar eventuais distorções decorrentes da transição para o novo modelo.

Por outro lado, como os investimentos das empresas de geração de controle federal, assim como das demais entidades do setor público federal, dependiam da prévia autorização do Ministério do Planejamento no Orçamento da União, com posterior discussão e aprovação no Congresso Nacional, tendo em vista o atendimento às metas de política econômica, o controle rigoroso sobre os gastos com infra-estrutura também comprometeu a alocação de recursos públicos na ampliação do parque gerador nacional.

Em suma, do exposto, parece ficar evidente que os idealizadores do modelo de reestruturação do setor elétrico brasileiro falharam ao não formular, com clareza, o marco jurídico institucional e os requisitos capazes de promover a expansão da oferta. Na ausência de tal cenário, a opção de transferir tal responsabilidade para o setor privado mostra-se equivocada, ao revelar que as próprias bases contratuais, que poderiam deixar confortáveis os agentes privados em suas decisões de investimentos, acabaram por minar a lógica do sistema. O episódio do racionamento energético, marca do ano de 2001, revela este equívoco.

Assim, com a finalidade central de mapear os principais encaminhamentos conduzidos pelo governo federal, em especial ao longo do biênio 2001/2002, no sentido de ajustar o modelo, pressionado pela crise energética vivenciada neste período, o próximo item tentará descrever as sugestões propostas pela Comissão de Análise do Sistema Hidrotérmico de Energia Elétrica (Relatório Kelman) e pelo Comitê de Revitalização do Modelo do Setor Elétrico, durante essa fase do processo $^{90}$.

\footnotetext{
${ }^{90}$ Ressalte-se que o foco da análise a ser desenvolvida no item 3.3.1 As tentativas de correção: as propostas do Relatório Kelman e do Comitê de Revitalização do Modelo do Setor Elétrico, limita-se a levantar as propostas de ajuste ao modelo, cabendo ao item 3.3.2 As principais medidas implementadas durante o racionamento e a Lei $\mathrm{n}^{\circ} 10.438 / 2001$, sintetizar brevemente as medidas emergenciais encaminhadas para contornar a crise de racionamento de 2001.
} 


\subsubsection{As tentativas de correção: as propostas do Relatório Kelman e da Câmara de Gestão da Crise de Energia Elétrica}

Em 22 de maio de 2001, o Presidente Fernando Henrique Cardoso instituiu a Comissão de Análise do Sistema Hidrotérmico de Energia Elétrica, com o objetivo central de avaliar, no prazo de sessenta dias, a política de produção energética e identificar as causas estruturais e conjunturais do desequilíbrio entre a demanda e a oferta de energia.

Partindo de um diagnóstico setorial sobre quais fatores físicos e regulatórios teriam levado à crise, em 21 de julho de 2001, a comissão divulgou seus trabalhos, em um relatório que passou a ser conhecido como "Relatório Kelmann", em homenagem ao seu coordenador, Jerson Kelman.

Sintetizado em onze anexos, os trabalhos da comissão concluíram que a maioria das causas relacionadas à crise do apagão esteve muito mais relacionada às mudanças estruturais implementadas no âmbito do processo de reestruturação do setor elétrico brasileiro do que por desequilíbrios conjunturais decorrentes da estiagem vivenciada ao final de 2000 e início de 2001. O Quadro 3.1., abaixo relacionado, reproduz os principais problemas apontados no referido trabalho, destacando suas respectivas sugestões de aprofundamento.

\section{Quadro 3.1.}

Sumário dos principais problemas apontados no Relatório Kelmann e os temas que deveriam ser investigados

\begin{tabular}{|c|c|}
\hline Problemas & Temas que merecem aprofundamento \\
\hline $\begin{array}{l}\text { Ineficácia na ação } \\
\text { governamental }\end{array}$ & $\begin{array}{l}\text { - Agilização da atuação do CNPE para garantir eficácia da ação intragovernamental. } \\
\text { - Fortalecimento da capacidade de ação do MME/Secretaria de Energia/CCPE. } \\
\text { - Aperfeiçoamento e valorização do contrato de gestão entre ANEEL e MME. } \\
\text { - Criação de um processo de licenciamento ambiental e de planejamento da } \\
\text { utilização dos recursos hídricos articulado entre MME e MMA. } \\
\text { - Revisão e consolidação da legislação do setor. }\end{array}$ \\
\hline $\begin{array}{c}\text { Insuficiência de ação } \\
\text { preventiva para } \\
\text { evitar racionamento } \\
\text { de grande } \\
\text { profundidade }\end{array}$ & $\begin{array}{l}\text { - Criação de procedimentos para diferentes níveis de "sinais de alerta" do ONS para } \\
\text { o MME em função do nível de esvaziamento e das condições hidrológicas } \\
\text { previstas. } \\
\text { - Definição de responsabilidades entre ANEEL, MME e ONS com relação à } \\
\text { programação de obras e projeção de demanda, usados em estudos de } \\
\text { confiabilidade. } \\
\text { - Criação de um procedimento de restrição progressiva da oferta de energia } \\
\text { hidrelétrica e/ou aumento de tarifa à medida que os reservatórios do ssitema } \\
\text { esvaziem. } \\
\text { - Adoção de uma função de custo de déficit por patamares de profundidade. }\end{array}$ \\
\hline
\end{tabular}




\begin{tabular}{|c|c|}
\hline $\begin{array}{l}\text { Falta de reserva de } \\
\text { segurança para } \\
\text { atendimento da } \\
\text { demanda em } \\
\text { situação de crise }\end{array}$ & $\begin{array}{l}\text { - Exame da possibilidade de usar encargos por capacidade para aumentar o nível de } \\
\text { confiabilidade do sistema. } \\
\text { - Exame de remoção das dificuldades que ainda retardam a implementação das } \\
\text { usinas a gás. }\end{array}$ \\
\hline $\begin{array}{l}\text { Insuficiência dos } \\
\text { Programas de } \\
\text { conservação de } \\
\text { energia }\end{array}$ & $\begin{array}{l}\text { - Revitalização do PROCEL e outros programas e medidas de conservação de } \\
\text { energia competitiva com a geração. }\end{array}$ \\
\hline $\begin{array}{l}\text { Insuficiência nos } \\
\text { sinais econômicos } \\
\text { para viabilização de } \\
\text { investimentos }\end{array}$ & $\begin{array}{l}\text { - Revisão de critérios e periodicidade de cálculo dos certificados de energia } \\
\text { assegurada das usinas hidrelétricas e dos limites de contratação para termelétricas, } \\
\text { levando em consideração à dinâmica do uso múltiplo dos recursos hídricos. } \\
\text { - Criação de um ambiente regulatório estável, claro e conciso, em particular no que } \\
\text { se refere ao VN, à revisão tarifária e ao repasse de custos não gerenciáveis. } \\
\text { - Aumento do requisito mínimo de contratação para as distribuidoras. } \\
\text { - Liberação compulsória de grandes consumidores. } \\
\text { - Exame de impacto dos consumidores livres no planejamento econômico-financeiro } \\
\text { das Distribuidoras. } \\
\text { - Estabelecimento de compensações financeiras para consumidores não atendidos } \\
\text { dentro das obrigações contratuais. } \\
\text { - Revisão de rateios e subsídios cruzados. }\end{array}$ \\
\hline $\begin{array}{l}\text { Ineficácia na } \\
\text { correção de falhas } \\
\text { de mercado }\end{array}$ & $\begin{array}{l}\text { - Formação de catálogo de projetos hidrelétricos e térmicos, já com estudos de } \\
\text { dimensionamento, localização e permissões ambientais para serem oferecidos aos } \\
\text { investidores. } \\
\text { - Definição de ações do Governo, nos casos em que for identificada uma situação de } \\
\text { alerta, para licitação ou contratação emergencial. } \\
\text { - Exame do papel do Governo como comprador de última instância de energia } \\
\text { produzida por usinas de interesse estratégico. } \\
\text { - Aperfeiçoamento do planejamento indicativo de geração, cotejando com a } \\
\text { experiência internacional. }\end{array}$ \\
\hline
\end{tabular}

Fonte: Montado a partir da informações constantes do Relatório da Comissão de Análise do Sistema Hidrotérmico de Energia Elétrica, 21/07/2001. Elaboração própria.

Em paralelo, também em maio de 2001, por meio da Medida Provisória $\mathrm{n}^{\circ} 2.147$, foi criada e instalada a Câmara de Gestão da Crise de Energia Elétrica (GCEE), presidida pelo então Ministro da Casa Civil da Presidência da República, com o objetivo de propor e implementar medidas de natureza emergencial, de maneira a compatibilizar a demanda e a oferta de energia elétrica, dada a crítica situação hidrológica que atravessava o país, evitando-se, assim, interrupções intempestivas ou imprevistas do suprimento de energia elétrica.

Ademais, mediante um processo de aprimoramento do novo modelo do Setor Elétrico Brasileiro, a GCEE, através da Resolução $n^{0}$ 18, de 22 de junho de 2001, criou o Comitê de Revitalização do Modelo do Setor Elétrico, cuja instalação ocorreu em 27 de junho de 2001, com a missão de encaminhar propostas para corrigir as disfunções correntes 
e propor aperfeiçoamentos para o referido modelo. Ressalte-se, entretanto, que na ocasião, conforme lembrado no Relatório de Progresso n. ${ }^{\circ} 3$ (2002, p. 6),

"ficou acordado que os trabalhos desenvolvidos pelo Comitê deveriam pautar-se na busca de soluções que preservassem os pilares básicos de funcionamento do modelo do setor, a saber: a) competição nos segmentos de geração e comercialização de energia elétrica; b) expansão dos investimentos necessários com base em aportes do setor privado e; c) regulação dos segmentos que são monopólios naturais - transmissão e distribuição de energia elétrica - para garantir a qualidade dos serviços e o suprimento de energia elétrica de forma compatível com as necessidades de desenvolvimento do país".

Assim, ao se avaliar o conjunto de medidas divulgado nos Relatórios de Progresso no s. 1, 2, 3 e 4, do Comitê de Revitalização do Modelo do Setor Elétrico, percebe-se claramente a preocupação do governo federal em tentar corrigir as "disfuncionalidades" do modelo, propondo seu aperfeiçoamento, mas preservando sua orientação original, qual seja, de fortalecimento do mercado, reforço dos instrumentos de competição e de defesa da concorrência, bem como de expansão da participação do setor privado neste segmento da infra-estrutura nacional.

Nessa linha, o Quadro 3.2 busca organizar de maneira sumária, a partir das questões apresentadas nos relatórios de progresso acima mencionados, os objetivos centrais que resultaram dos trabalhos desenvolvidos pelo comitê.

Quadro 3.2.

Síntese dos Relatórios de Progresso do Comitê de Revitalização do Setor Elétrico (*)

\begin{tabular}{|c|c|}
\hline Objetivos Centrais & Principais medidas relacionadas \\
\hline $\begin{array}{l}\text { Normalizar o funcionamento do } \\
\text { setor, através de medidas de } \\
\text { curto prazo }\end{array}$ & $\begin{array}{ll}\text { - } & \text { Acordo Geral do Setor } \\
\text { - } & \text { Reestruturação do MAE } \\
\text { - } & \text { Aperfeiçoamento do processo de despacho e formação de preços }\end{array}$ \\
\hline $\begin{array}{l}\text { Fortalecer o mercado, } \\
\text { reforçando os instrumentos de } \\
\text { competição nos setores de } \\
\text { geração e comercialização para } \\
\text { consumidores livres }\end{array}$ & $\begin{array}{l}\text { - } \quad \text { Implementação da oferta de preços } \\
\text { - } \quad \text { Comercialização da energia para consumidores livres } \\
\text { - } \quad \text { Papel dos consumidores livres e cativos }\end{array}$ \\
\hline $\begin{array}{l}\text { Assegurar a expansão da oferta } \\
\text { de energia, de maneira a suprir a } \\
\text { demanda em termos estruturais }\end{array}$ & $\begin{array}{ll}\text { - } & \text { Estímulo à contratação bilateral } \\
\text { - } & \text { Revisão das energias asseguradas } \\
\text { - } & \text { Contratação de geração de reserva } \\
\text { - } & \text { Estímulo à expansão da capacidade de suprimento de ponta } \\
\text { - } & \text { Incentivo à conservação e uso racional da energia } \\
\text { - } & \text { Agilização do processo de licenciamento ambiental }\end{array}$ \\
\hline
\end{tabular}




\begin{tabular}{|c|c|}
\hline $\begin{array}{l}\text { Interface entre Mercado e } \\
\text { Setores Regulados, visando } \\
\text { assegurar a passagem de sinais } \\
\text { econômicos adequados do setor } \\
\text { regulado para o competitivo. }\end{array}$ & $\begin{array}{ll}\text { - } & \text { Revisão das tarifas de transmissão } \\
\text { - } & \text { Mudanças no Valor Normativo } \\
\text { - } & \text { Metodologias de planejamento da expansão da rede de transmissão }\end{array}$ \\
\hline $\begin{array}{l}\text { Monitorar a confiabilidade de } \\
\text { suprimento, criando "sinais de } \\
\text { alerta" com relação a riscos de } \\
\text { suprimento a curto ( } 2 \text { anos) e } \\
\text { médio ( } 3 \text { a } 6 \text { anos) prazos, de } \\
\text { maneira a desencadear, em caso } \\
\text { de necessidade, medidas de } \\
\text { contenção por parte do } \\
\text { MME/CNPE }\end{array}$ & 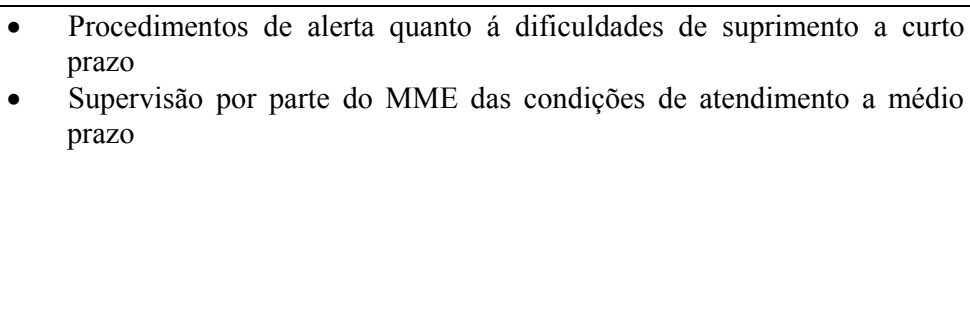 \\
\hline $\begin{array}{l}\text { Defesa da concorrência, através } \\
\text { de ações que visem prevenir o } \\
\text { exercício do poder de mercado } \\
\text { por parte dos agentes }\end{array}$ & $\begin{array}{l}\text { - } \\
\text { - } \\
\text { - } \\
\text { - Abesverticalizaçãa para das particelas das tarifas de distribuição } \\
\text { Aperfeiçoamentos e definições das revisões tarifárias periódicas das } \\
\text { concessionárias de distribuição de energia elétrica, em particular quanto à } \\
\text { determinação da base de remuneração regulatória e do "Fator X" }\end{array}$ \\
\hline $\begin{array}{l}\text { Realismo tarifário e defesa do } \\
\text { consumidor, com o objetivo de } \\
\text { melhoria do serviço prestado } \\
\text { com tarifas aderentes aos custos }\end{array}$ & $\begin{array}{ll}\text { - } & \text { Universalização do atendimento } \\
\text { - } & \text { Tarifa social para consumidores de baixa renda } \\
\text { - } & \text { Fontes alternativas de energia } \\
\text { - } & \text { Incentivo à geração térmica a gás natural } \\
\text { - } & \text { Realinhamento tarifário }\end{array}$ \\
\hline $\begin{array}{l}\text { Aperfeiçoamento } \\
\text { instituições, visando reforçar a } \\
\text { eficácia e a transparência de } \\
\text { atuação dos agentes } \\
\text { institucionais do setor }\end{array}$ & $\begin{array}{ll}\text { - } & \text { Reorganização institucional do MME } \\
\text { - } & \text { Governança do ONS } \\
\text { - } & \text { Finalização e aperfeiçoamento dos modelos computacionais utilizados } \\
\text { - } & \text { Aperfeiçoamento das regras do MAE } \\
\text { - } & \text { Aperfeiçoamento do processo de definição de submercados e das regras } \\
& \text { do mecanismo de realocação de energia }\end{array}$ \\
\hline
\end{tabular}

Fonte: Elaboração própria, a partir das informações contidas nos Relatórios de Progresso, elaborados pelo Comitê de Revitalização do Modelo do Setor Elétrico.

(*) Registre-se que, em 10 de janeiro de 2002, o Comitê divulgou o primeiro relatório, com 18 medidas, ampliadas para 33, no mês seguinte, as quais foram agrupadas em oito objetivos centrais, que serviram de orientação para a elaboração desse Quadro 3.2. O Relatório de Progresso no 3 , divulgado em junho de 2002, selecionou, por sua vez, apenas 11 tópicos entre os 33 relacionados no relatório anterior, tendo em vista seus efeitos estruturais no modelo do setor elétrico e também por estarem intrinsicamente relacionados. Já o Relatório de Progresso $\mathrm{n}^{\mathrm{O}} 4$ foi divulgado em novembro de 2002, concluindo os trabalhos.

A partir das informações contidas nos quadros anteriores, em especial nas questões apontadas no Relatório Kelman (Quadro 3.1), verifica-se que parte dos problemas detectados revela pontos análogos às preocupações expressas nas páginas anteriores do presente trabalho, em especial no que se refere à necessidade de aperfeiçoamento tanto do ponto de vista dos aspectos institucionais quanto mercantis, que contornam o modelo.

No primeiro caso, a alteração central passa pela reestruturação do Mercado Atacadista de Energia (MAE), que, além de sofrer uma mudança em sua estrutura 
administrativa, com a introdução de uma Assembléia Geral ${ }^{91}$, passa a ser regulado pela própria ANEEL. Com isso, o governo intervirá diretamente nesse mercado, estabelecendo regras e fiscalizando, inclusive, a Administradora de Serviços do MAE (ASMAE), na tentativa de romper a distorção anterior, onde a tarefa de estabelecer e gerenciar as condições de negociação cabia aos seus próprios agentes (vendedores e compradores de energia), o que, claramente, acabou por transformar o MAE em um eterno ambiente de conflitos $^{92}$.

Além disso, foi enfatizada a necessidade de se reestruturar o Ministério das Minas e Energia (MME), com capacitação para realizar o planejamento da transmissão, bem como adequar sua metodologia de planejamento determinativo, incluindo as interconexões regionais e internacionais, ao ambiente de competição estabelecido nos segmentos de geração e comercialização de energia elétrica. Os relatórios destacam, ainda, que, no processo de reestruturação do MME, serão estabelecidas as interfaces com a ANEEL e com o ONS.

Tais mudanças parecem reforçar uma das principais preocupações identificadas nos trabalhos, qual seja: redefinir com clareza o papel jurídico-institucional, atribuído a cada um dos agentes. De um lado, parece ter sido identificada à necessidade de que o Ministério das Minas e Energia (MME) assuma a tarefa de executor do planejamento, na tentativa de recuperar o comando do setor, e de outro, preservar a ANEEL, enquanto agente fiscal e regulador, em especial na sua nova atribuição de fiscalizar o MAE. Esta proposta busca sedimentar um quadro institucional independente, onde as responsabilidades e as atribuições dos agentes envolvidos estejam definidamente contornadas.

Quanto às questões mercantis, a primeira mudança apontada centra-se no aperfeiçoamento do mercado, em particular no que se refere ao processo de despacho e formação dos preços, bem como ao detalhamento do esquema referente à própria oferta de energia, de maneira a vincular o despacho comercial, onde cada agente exprime sua

\footnotetext{
${ }^{91}$ Foi introduzida a obrigatoriedade de eleição de seu Conselho de Administração, colegiado composto por profissionais eleitos pela Assembléia Geral e indicados pelo Ministério das Minas e Energia, e excepcionalmente pela ANEEL, com a aprovação de suas contas pela diretoria.

92 Prova desse conflito pôde ser assistido durante o episódio da crise energética, onde as geradoras e as distribuidoras, ao não entrarem em acordo sobre as condições de ressarcimento pleiteado pelas últimas, como forma de compensar a energia não entregue pelas primeiras, mas prevista no contrato de fornecimento, em decorrência do racionamento, levaram à intervenção da ANEEL no MAE, e a, posterior, assinatura de um Acordo Geral do Setor Elétrico, cujas bases foram sintetizadas em Branco e Sampaio (2002).
} 
disposição a produzir através de ofertas de preço e quantidade, ao uso de energia armazenada do sistema, ao invés de produção física das usinas. Com isso, o ONS operaria de maneira mais eficiente os reservatórios, ao calcular, em cada período de comercialização, a energia contábil total resultante da soma das "retiradas" ou "depósitos" em todas as "contas" de energia, independentemente de quem fossem os proprietários das usinas.

Os relatórios apontam, também, para a necessidade de se regulamentar a energia comercializada pelas concessionárias geradoras de serviço público sob controle federal, através de leilões, cujas regras e procedimentos seriam estabelecidos pela ANEEL e sua realização conduzida pelo MAE. O objetivo desta medida seria assegurar uma competição equilibrada entre empresas privadas e estatais, uma vez que essas últimas, ao deter grande fatia do mercado de geração, poderiam inibir novos investimentos, por parte do setor privado, pelo temor de que as empresas públicas utilizassem seu poder de mercado para deslocar seus competidores.

Ainda no âmbito da esfera mercantil, os trabalhos enfatizaram a necessidade de se aperfeiçoar os incentivos à contratação bilateral, tendo em vista a volatilidade das tarifas de energia no mercado de curto prazo em sinalizar com eficiência a necessidade de entrada de nova geração, que, como apresentado anteriormente, espera que a expansão do sistema ocorra pela disposição de contratar por parte da demanda. Assim, os contratos bilaterais assumiriam um papel expressivo na expansão da oferta, uma vez que as distribuidoras passariam a adquirir energia para seus consumidores cativos, através de licitação de contratos bilaterais de longo prazo ${ }^{93}$.

Este mecanismo, conforme apontado no Relatório de Progresso no 3 (2002, p. 23), “é transparente, eficiente - pois leva à contratação de mínimo custo em decorrência da competição de diversas fontes de energia e alternativas de investimento - e permite criar uma referência de mercado para o Valor Normativo". Neste particular, os trabalhos apontam para a substituição do Valor Normativo - VN, de difícil mensuração pelo fato de não existir uma referência externa de tarifas de energia elétrica no sistema brasileiro, por

\footnotetext{
${ }^{93}$ No Capítulo 4 serão analisados os contratos bilaterais de longo prazo realizados com as empresas eletrointensivas.
} 
um VN único que seria baseado no custo médio de implementação de uma nova hidroelétrica, o qual resultou mais competitivo que a alternativa térmica de gás natural.

Por fim, registre-se a preocupação levantada pelo comitê quanto à necessidade de se definir procedimentos adequados para a realização das revisões tarifárias periódicas das concessionárias, incluindo a metodologia para a determinação da Base de Remuneração Regulatória e do Fator "X". Lembrando que a ANEEL já havia contratado consultores especializados na matéria, em função dos processos de revisão tarifárias iniciados em 2002 e das 40 concessionárias, cujos processos teriam início em 2003, os trabalhos do comitê enfatizam que:

\footnotetext{
“a revisão tarifária constitui a própria fundamentação do princípio de modicidade tarifária aplicado ao serviço público de distribuição de energia elétrica. A revisão tarifária não traduz uma arbitrária redução da receita da concessionária, mas o resultado do adimplemento do dever de prestar os melhores serviços pelos menores preços. Mais precisamente, a nova alternativa trazida pelo atual regime tarifário não importa redução da remuneração da concessionária, mas transferência para a sociedade de uma parte dos benefícios por ela auferidos", [Relatório de Progresso n 3 (2002, p. 47)].
}

Em paralelo à preocupação de se introduzir procedimentos de revisão tarifária, capazes de transferir ao consumidor ganhos decorrentes de eventuais incrementos de produtividade conseguidos pelas empresas distribuidoras de energia elétrica, o comitê destaca em seus trabalhos, que, embora o realismo tarifário acompanhe os custos dos serviços prestados, a defesa do consumidor também deve ser garantida. Assim, admitindo que o serviço de fornecimento de energia elétrica é universal e seu atendimento alcance o conjunto da sociedade, admite a necessidade de se introduzir tarifas sociais para consumidores de baixa renda.

Com esse conjunto de informações, evidencia-se que, pelo menos ao longo do biênio 2001/2002, motivado em parte pela crise energética e a partir dos trabalhos apresentados no Relatório Kelman e pelo Comitê de Revitalização do Modelo do Setor Elétrico, a gestão FHC parece ter formalizado alguns limites do processo de reestruturação desenhado para o setor elétrico brasileiro. De fato, esses trabalhos contribuíram para que o debate, no sentido de redefinir uma estratégia para o setor, mesmo que avaliada a partir do atual modelo híbrido, avançasse, sinalizando, inclusive a fragilidade do modelo regulatório e da reestruturação idealizada vis à vis as particularidades do setor elétrico nacional. 
Como coloca Araújo (s/d, p 7-8) $)^{94}$, para se introduzir com sucesso a competição no setor elétrico, deveriam estar asseguradas três condições básicas, a saber: margem confortável de capacidade ociosa no sistema (geração, transmissão e distribuição), crescimento lento da demanda e oferta abundante de outras fontes alternativas de energia. No Brasil, ao contrário, nos últimos seis anos, o consumo cresceu a taxas maiores que a capacidade de geração. Além disso, como 95\% da geração de eletricidade são provenientes de usinas hidrelétricas, queda nos níveis de reservatórios, em decorrência de um período de seca e/ou pelo consumo superior do que pode ser reposto em base regular, afeta ainda mais a oferta de energia elétrica nacional. Ameaça, também, essa situação, a frágil legislação sobre os usos múltiplos das águas que pode revelar ou agravar problemas hídricos e de conflito de interesses.

No caso da transmissão, além das perdas estimadas em $12 \%$, verifica-se, nos últimos anos, uma queda nos investimentos nesse segmento, em resposta aos corte dos investimentos públicos federais. Comprometendo ainda mais este cenário, o governo central não conseguiu deslanchar seu programa de geração térmica, em grande medida pelos riscos regulatórios relacionados à importação do gás da Bolívia e da Argentina, ligados ao preço do petróleo e às variações cambiais, até o momento, não equacionados.

Dessa forma, percebe-se que usar o modelo inglês, em condições de escassez de oferta, presentes no caso brasileiro, acentuou a volatilidade de preços e as possibilidades para uso do poder de mercado e extração de rendas. De acordo com Araújo (s/d), o ônus só não foi maior dada à exigência de que contratos bilaterais cobrissem pelo menos $85 \%$ das transações de energia. Mesmo assim, os consumidores cativos (com demanda inferior a 10 MW) acabaram assumindo parcialmente esses equívocos do modelo, uma vez que as tarifas são acompanhadas pela $\mathrm{ANEEL}^{95}$, com base em contratos assinados à época das

\footnotetext{
94 Essa preocupação, conforme sinalizou Araújo (s/d, p.7-8), foi lembrada em um texto de Joskow e Schamalense, datado de 1983, intitulado Market for Power, e por tantos outros autores, a partir da experiência inglesa, entre os anos de 1992 e 2000.

${ }^{95}$ Cumpre lembrar que o método tarifário definido nestes contratos de concessão é o Price Cap, pelo qual, como visto, a partir do estabelecimento de uma tarifa média, as empresas têm liberdade de gestão para buscar reduções de custos e apropriar-se de ganhos de produtividade. Tais ganhos, por sua vez, após um prazo de cinco anos, deveriam ser repassados, pelo menos parcialmente, para os consumidores. Infelizmente, os reajustes aprovados às distribuidoras estaduais de energia elétrica não revelam a introdução de nenhum mecanismo redutor de tarifas. Ao contrário, após a crise de racionamento, os consumidores passaram a assumir parte da queda das receitas dessas empresas.
} 
privatizações, que, na sua maioria, estabeleceram o IGP-M, um dos indicadores que mais é contaminado pelo movimento do câmbio, como indexador ${ }^{96}$.

\subsubsection{As principais medidas implementadas durante $o$ racionamento e a Lei $\mathbf{n}^{0}$ $10.438 / 2001$}

Em paralelo aos trabalhos das comissões, o governo federal, através da Câmara de Gestão da Crise de Energia Elétrica (GCEE), editou um conjunto de medidas de caráter emergencial, que vigoraram entre junho de 2001 a março de 2002, com o intuito central de reduzir a demanda de energia no país. Assim, foi fixada como meta principal do racionamento a redução de $20 \%$ sobre o consumo médio de energia realizado em maio, junho e julho de 2000, em cada unidade de consumo, a partir de maio de 2001, para as empresas e, de junho, para as famílias. Para garantir a efetividade do racionamento, o governo federal associou ainda a essa medida normas de aumentos progressivos e escalonados de tarifa, até possibilidade de cortes no fornecimento, aplicadas aos consumidores que não atingissem a meta, e a garantia de bônus (em $\mathrm{kWh}$ ) para aqueles que reduzissem seu consumo a partir de determinada escala. Para as empresas, o governo também previu a aplicação do tarifaço para os que não atingirem a meta, permitindo, ainda, para aquelas com energia contratada superior a 2,5 $\mathrm{MW}$, vender em leilão a energia contratada não utilizada.

Além disso, na ocasião, foi anunciada, também, a criação de um Programa Emergencial de Contratação de Energia, estabelecendo as seguintes medidas: a) criação de uma empresa estatal denominada Comercializadora Brasileira de Energia Emergencial (CBEE), com prazo para atuar até junho de 2006, com a tarefa de viabilizar, em curto prazo, o aumento da capacidade de geração e da oferta de energia em qualquer fonte; b) a contratação, através da estatal criada, as novas usinas termelétricas com prazo máximo para começar a operar até 31 de julho de 2002; e c) o lançamento do edital convocando empresas com produção acima de $10 \mathrm{MW}$ para fornecer energia a partir de óleo diesel e/ou óleo combustível.

\footnotetext{
${ }^{96}$ Cumpre ressaltar, ainda, que as privatizações da Escelsa, Light e Cerj foram realizadas antes da criação e montagem da ANEEL, refletindo em cláusulas contratuais extremamente favoráveis e vagas quanto aos temas de qualidade e de investimentos, como forma de atrair compradores. Esta estratégia comprometeu, não apenas a tarefa do regulador, cuja diretoria foi montada em dezembro de 1997, quando 10 empresas já haviam sido privatizadas, revelando um passivo de contratos regulatórios já firmados, mas as próprias opções de reforma.
} 
Na verdade, essa medida, conforme aponta Vieira (2005, p. 120-121), serviria como um seguro para os consumidores das regiões afetadas pelo racionamento, ao permitir esse tipo de contratação,

"por um curto período de tempo, de maneira a reduzir a dependência do sistema aos regimes hidrológicos dos anos seguintes, estabelecendo uma forma eficiente para aguardar a implantação dos projetos de geração hidráulica e térmica, bem como as linhas de transmissão, que aumentariam a disponibilidade de energia de forma permanente".

Isto porque, do lado da oferta, o Ministro das Minas e Energia, como sempre acontece em situações de crise, divulgou o Programa Emergencial de Aumento de Energia, sinalizando a ampliação da capacidade instalada, entre 2001 e 2003, em 19.670 MW, assim distribuída: a) 6.900 MW com obras de ampliação e construção de 20 novas usinas hidrelétricas; b) 10.000 MW obtidos com a entrada em operação de 41 usinas termoelétricas, sendo 15 delas com obras já iniciadas, com previsão de geração de 5.475 MW; e c) $2.770 \mathrm{MW}$ através da importação de países vizinhos.

A efetivação, contudo, de tal iniciativa sempre foi discutível, uma vez que o próprio Programa Prioritário de Termeletricidade - PPT, divulgado em fevereiro de 2000 pelo governo federal que previa a implantação de 49 termoelétricas, com o objetivo de adicionar cerca de 20.000 MW ao sistema elétrico brasileiro, até final de 2003, teve sua meta comprometida. De fato, os receios cambiais relacionados a tais projetos limitaram a atuação do setor privado, permitindo que apenas os projetos que contaram com a parceria da Petrobrás fossem iniciados, revelando, novamente, os limites de se transferir às mãos privadas, mesmo com apoio de financiamento do BNDES, a tarefa de ampliar a base energética nacional.

Posteriormente, o governo federal, a partir de um "Acordo Geral”, em dezembro de 2001, instituiu um conjunto de medidas complementares, sancionadas pela Lei $\mathrm{n}^{\mathrm{o}}$ $10.438 / 2002$, que teve como objetivo central estabelecer as normas de rateio, entre as classes de consumidores finais atendidas pelo Sistema Elétrico Nacional Interligado, dos custos relativos às contratações emergenciais efetuadas em razão do racionamento imposto entre junho de 2001 a março de 2002, o que ficou conhecido como "seguro anti-apagão"97.

\footnotetext{
${ }^{97}$ De fato, esse seguro, que passou a incidir sob o título de "encargo de capacidade emergencial" nas contas de energia desde $1^{\circ}$ de março de 2002, surgiu, como visto, em junho de 2001, quando foi permitida, através da criação de um programa emergencial, a possibilidade de contratação de energia em caráter excepcional
} 
As medidas aprovadas, não incidentes apenas sobre os consumidores residenciais denominados de "baixa renda", permitiram recompor as perdas impostas às concessionárias durante o racionamento, ao acrescentar cinco encargos adicionais, explicitados por Sauer (2003, p. 167), sobre as contas dos demais consumidores de energia elétrica, a vigorar a partir de $1^{\circ}$ de março de 2002, com fím do racionamento, até 31 de dezembro de 2005, quais sejam:

- recomposição tarifária extraordinária (dado o período de racionamento);

- encargo de capacidade emergencial;

- encargo de aquisição de energia elétrica emergencial;

- encargo de energia livre adquirida no MAE;

- ressarcimento de acréscimos de custos "não-gerenciais", durante o período de $1^{\circ} \mathrm{de}$ janeiro a 25 de outubro de 2001.

Além disso, as empresas distribuidoras passaram a receber um adiantamento de 90\% do negociado como "perdas" na forma de empréstimos do BNDES, cujo pagamento foi viabilizado através de aumentos tarifários de 21 de dezembro de 2001 (2,9\% consumidor residencial e $7,9 \%$ para a indústria e comércio) ${ }^{98}$, permitindo minimizar, através de recursos públicos e aumento de tarifas os eventuais prejuízos resultantes da redução da demanda imposta a toda a sociedade.

Como o objetivo de aumentar a participação da energia elétrica produzida por empreendimentos de Produtores Independentes Autônomos, concebidos com base eólica, pequenas centrais hidrelétricas e biomassa, no Sistema Elétrico Interligado Nacional, na oportunidade, foram divulgadas as bases do Programa de Incentivo às Fontes Alternativas de Energia Elétrica - PROINFA, cuja regulamentação ocorreu em março de 2004, durante a gestão do Presidente Luís Inácio Lula da Silva.

repassando tais encargos aos consumidores.

${ }^{98}$ A análise do efeito de tais medidas sobre a tarifa paga pelos consumidores pode ser encontrada em Vieira (2005). 
A par desse conjunto de informações, verifica-se um aumento nas tarifas de energia, em especial para os consumidores industriais, cuja variação ocorrida entre os anos de 1999 a 2002, em termos reais, pode ser constada através da Tabela 3.7.

Tabela 3.7.

Preços médios de energia para 1999-2002

\begin{tabular}{|c|c|c|}
\hline \multirow[b]{2}{*}{ Ano } & \multicolumn{2}{|c|}{ Tarifas Selecionadas } \\
\hline & $\begin{array}{l}\text { Residencial }^{(2)} \\
\mathrm{R} \$ / \mathrm{MWh}\end{array}$ & $\begin{array}{c}\text { Industrial }^{(3)} \\
\mathrm{R} \$ / \mathrm{MWh}\end{array}$ \\
\hline 1999 & 133,919 & 35,268 \\
\hline 2000 & 133,098 & 35,869 \\
\hline 2001 & 138,625 & 37,406 \\
\hline 2002 & 141,843 & 41,257 \\
\hline
\end{tabular}

(1) Deflator IGP-DI; (2) Tarifa CESP (R\$ por MWh), para categoria de consumo residencial na faixa de 101 a $200 \mathrm{KWh}$ (sem ICMS) e (3) Tarifa CESP (R \$ por MWh), para categoria A2, intensidade de 88 a $138 \mathrm{kv}$ (sem ICMS)

Fonte: extraído de DIESP (2003, p. 54)

Assim, apesar de todos os esforços no sentido de sinalizar mudanças, em especial no biênio 2001/2002, o setor manteve-se mergulhado em um ambiente de incertezas, resultado, de um lado, da forma prematura com que foram encaminhadas sua desverticalização e privatização, e de outro, da falta de regras claras de atuação dos diversos agentes envolvidos, uma vez que a gestão FHC, mesmo após o racionamento, nada vez de concreto para reverter "a renúncia, pelo Estado, de seu papel de planejador e orientador de políticas em um setor de vital importância para o desenvolvimento social e econômico do país"99.

Neste cenário, a próxima tarefa é avaliar quais medidas foram adotadas, durante o biênio 2003/2004, com a posse da nova equipe no Ministério das Minas e Energia, no sentido de contornar esses desajustes anteriormente retratados e como a regulação econômica passou a ser vista pelo governo Lula.

\subsection{O "novíssimo" modelo institucional do setor elétrico brasileiro: a revisão ocorrida entre 2003/2004 e os resultados dos leilões de energia realizados em 2004 e 2005}

Registre-se que, desde o início do período eleitoral, em 2002, já era evidente, nos discursos do então candidato à Presidência da República, Luís Inácio Lula da Silva, baseados em uma cartilha divulgada pelo Instituto Cidadania, sob o título de Diretrizes e

${ }^{99}$ Sauer (2002, p. 2) 
Linhas de Ação para o Setor Elétrico Brasileiro, seu forte posicionamento com relação à necessidade de se rever o modelo de reestruturação, em curso no País.

Dentro de uma linha oposicionista, o texto enfatiza a necessidade de se adotar um modelo, no qual o conceito de serviço público para as atividades de geração, transmissão e distribuição de energia elétrica substitua a visão "puramente de mercado que o modelo neoliberal tentou imprimir sem sucesso"100. A partir desse enfoque, seis premissas básicas norteiam as alterações propostas para o setor elétrico brasileiro, são elas:

a) Extinção do Mercado Atacadista de Energia - MAE, dado o entendimento de que o modelo mercantil idealizado para o setor é equivocado, frente ao seu papel marginal, tornando inadequada a subordinação total da operação, organização e expansão do sistema elétrico a essa lógica de curto prazo;

b) Resgate e aperfeiçoamento do sistema de planejamento determinativo, integrado, regionalizado e descentralizado, articulando a política do setor com outras políticas de desenvolvimento, tais como industrial, agrícola, tecnológica, de transportes, ambiental etc, com o caráter de atividade permanente e seqüencial;

c) Retomada do sistema de tarifas pelo custo do serviço, de forma a reduzir as incertezas e os riscos para produtores e consumidores, assegurando a licitação por blocos de energia;

d) Democratização e fortalecimento do sistema de regulação, promovendo a integração da regulação técnica e econômica com o planejamento, bem como a articulação das agências regulatórias afins, a saber: Agência Nacional de Águas - ANA; Agência Nacional de Energia - ANEEL; e Agência Nacional de Petróleo - ANP;

e) Reestruturação e recuperação do caráter público do Operador Nacional do Sistema Elétrico - ONS;

f) Garantia de que a energia advinda dos projetos hidráulicos existentes (energia velha), bem como do aproveitamento do potencial de recursos naturais, seja destinado, de forma prioritária, ao serviço público, cooperativo ou comunitário.

\footnotetext{
${ }^{100}$ Instituto Cidadania (2002, p. 9).
} 
Ao delinear esses princípios, os oposicionistas, de um lado, negam o modelo baseado puramente no mercado, no qual a indução da expansão do setor dar-se-ia através de preços e da competição pura, mas, por outro lado, defendem o papel do planejamento setorial integrado, tentando reorganizar as bases institucionais necessárias para a criação de um ambiente seguro e transparente, visando assegurar o atendimento da demanda de energia e a expansão do setor, de forma confiável, com racionalidade e em bases sustentáveis.

Foi exatamente com essa preocupação que, logo após a posse do Presidente Luís Inácio Lula da Silva, no âmbito do Ministério de Minas e Energia - MME, foi montado um grupo de trabalho com o "objetivo de assessorar na formulação e implementação da reforma institucional do setor elétrico" ${ }^{\prime 101}$. Com base na contribuição desse grupo $^{102}$, foi formulada a "Proposta de Modelo Institucional do Setor Elétrico", cuja primeira versão foi publicada, em julho de 2003, e a partir de sua divulgação, foram realizadas diversas reuniões e seminários com representantes de distintos níveis de governo, de empresas, dos consumidores e dos sindicatos, com o objetivo de apresentar, discutir e receber sugestões à proposta do MME. Esse trabalho foi finalizado, em dezembro de 2003, com a publicação do texto "Modelo Institucional do Setor Elétrico", pelo MME.

A primeira versão da proposta de mudança inicia-se listando os principais objetivos e pressupostos que deveriam orientar a adequada revisão do arranjo institucional do setor elétrico brasileiro. Dentre os objetivos destacam-se: i) modicidade tarifária para os consumidores; ii) continuidade e qualidade na prestação do serviço; iii) justa remuneração para os investidores, de modo a incentivá-los a expandir o serviço; e iv) universalização do acesso e do uso dos serviços de energia elétrica. Completando os objetivos centrais do modelo, a proposta enfatiza a necessidade de se respeitar os contratos existentes, minimizar os custos de transação durante o período de implantação, evitando-se a criação de pressões tarifárias adicionais para o consumidor, de maneira a criar um ambiente propício à retomada de investimentos, e implantar, de forma gradual, o novo modelo ${ }^{103}$.

\footnotetext{
${ }^{101}$ Artigo $1^{\mathrm{o}}$, da Portaria MME n⿳0 40, de 06 de fevereiro de 2003.

${ }^{102}$ Ressalte-se que, em decorrência de algumas divergências quanto à revisão do modelo de reestruturação do setor elétrico, o constituição original do grupo foi desfeita, entre maio e junho de 2003.

${ }^{103}$ Ministério de Minas e Energia (2003, p. 4).
} 
A partir de uma contextualização do processo de reestruturação estabelecido durante meados de década de 90, o texto resume os princípios básicos do novo modelo proposto, reforçando:

a) Prevalência do Conceito de Serviço Público: centra-se no entendimento de que produção de energia deve ser realizada, prioritariamente, por concessionária de serviço público, principalmente quando destinada aos consumidores cativos.

b) Modicidade Tarifária: sua manutenção é fundamental no novo modelo, pois se alinha com outros requisitos relacionados à correta prestação do serviço público, a saber: regularidade, eficiência, segurança, atualidade, generalidade e cortesia. Para que seja garantida, a proposta defende a retomada do planejamento da expansão do sistema, em caráter determinativo, com a introdução de mecanismos que, "preservados os benefícios da competição, permitam que a renda decorrentes da permanência em operação de ativos depreciados possa contribuir para a modicidade tarifária"104.

c) Mitigação dos Riscos Sistêmicos, tanto para investidores como para consumidores, será viabilizada com a adoção de competição pelo direito de participar do atendimento ao mercado, o que trará segurança a todos os agentes do setor;

d) Universalização do acesso e uso dos serviços de eletricidade, dado o peso desse serviço para a vida das pessoas e para o desenvolvimento do país, só será atendido através de políticas públicas específicas;

e) Transparência e Contestação Pública, como o novo arranjo institucional defende o planejamento como fundamental e decisivo, para o êxito do modelo, torna-se necessária à incorporação de contestação pública nos distintos estágios do planejamento, com o objetivo de garantir a máxima transparência das ações do setor.

\footnotetext{
${ }^{104}$ Ministério de Minas e Energia (2003, p. 9).
} 
$\mathrm{Na}$ seqüência, o documento apresenta as bases do novo modelo institucional, descrevendo os principais agentes e suas respectivas funções, que, na versão final do MME, foram renomeados, conforme explicita o Quadro 3.3. ${ }^{105}$, revelando, inclusive, a principal orientação da nova proposta, isto é, resgatar o poder de planejamento do setor, de maneira a garantir a segurança de suprimento.

Quadro 3.3.

Principais agentes e suas funções

\begin{tabular}{|c|c|}
\hline Agentes & Funções \\
\hline $\begin{array}{l}\text { Conselho Nacional de Política } \\
\text { Energética - CNPE }\end{array}$ & $\begin{array}{c}\begin{array}{c}\text { Homologação da política energética, em articulação com as demais políticas } \\
\text { públicas }\end{array}\end{array}$ \\
\hline $\begin{array}{l}\text { Ministério de Minas e Energia - } \\
\text { MME }\end{array}$ & $\begin{array}{c}\text { Formulação de políticas para o setor energético; implementação dessas } \\
\text { políticas energéticas; e exercício do poder concedente }\end{array}$ \\
\hline $\begin{array}{l}\text { Agência Nacional de Energia } \\
\text { Elétrica - ANEEL }\end{array}$ & $\begin{array}{l}\text { Mediação, regulação e fiscalização do funcionamento do sistema elétrico, } \\
\text { envolvendo o cumprimento das normas do marco regulatório em geral e das } \\
\text { obrigações dispostas nos atos de outorga (contratos de concessão, } \\
\text { autorização ou permissão) dos serviços de geração, transmissão e } \\
\text { distribuição }\end{array}$ \\
\hline $\begin{array}{c}\text { Empresa de Pesquisa Energética - } \\
\text { EPE }\end{array}$ & Execução dos estudos de planejamento energético \\
\hline $\begin{array}{l}\text { Câmara de Comercialização de } \\
\text { Energia Elétrica - CCEE }\end{array}$ & $\begin{array}{l}\text { Contabilização e liquidação de diferenças contratuais no curto prazo; e } \\
\text { administração dos contratos de compra de energia para atendimento aos } \\
\text { consumidores regulados }\end{array}$ \\
\hline $\begin{array}{l}\text { Operador Nacional do Sistema } \\
\text { Elétrico - ONS }\end{array}$ & $\begin{array}{l}\text { Operação integrada e centralizada do sistema elétrico interligado; e } \\
\text { administração da contratação das instalações de transmissão }\end{array}$ \\
\hline $\begin{array}{l}\text { Operador dos Sistemas Elétricos } \\
\text { Isolados - OSI }\end{array}$ & Coordenação da operação dos sistemas elétricos isolados \\
\hline $\begin{array}{l}\text { Comitê de Monitoramento do Setor } \\
\text { Elétrico - CMSE }\end{array}$ & $\begin{array}{c}\text { Monitoramento das condições de atendimento, no horizonte de cinco anos, } \\
\text { com o objetivo de assegurar a implementação de providências com vistas a } \\
\text { garantir a normalidade do suprimento de energia elétrica (coordenação do } \\
\text { MME, com apoio da EPE, CCEE, da ANEEL e do ONS) }\end{array}$ \\
\hline Eletrobrás & $\begin{array}{l}\text { Financiamento, em caráter suplementar, da expansão do setor elétrico; } \\
\text { exercício da função de holding das empresas estatais federais; administração } \\
\text { de encargos e fundos setoriais; comercialização da energia de Itaipu e de } \\
\text { fontes alternativas contempladas pelo PROINFA; e Coordenação do OSI }\end{array}$ \\
\hline
\end{tabular}

Fonte: Ministério de Minas e Energia (2003, p. 12/13). Elaboração própria.

Assim, partindo-se das diretrizes do CNPE, das projeções da Matriz Energética Brasileira e das metas especificadas pelo MME, em consonância com as demais políticas

\footnotetext{
${ }^{105}$ O nome Empresa de Pesquisa Energética - EPE substituiu o nome inicialmente proposto para esse novo agente, a saber: Fundação de Estudos e Planejamento Energético - FEPE. Da mesma forma, a instituição que sucedeu ao Mercado Atacadista de Energia - MAE, na origem denominado Administrador dos Contratos de Energia Elétrica - ACEE, foi renomeado para Câmara de Comercialização de Energia Elétrica - CCEE.
} 
públicas definidas pelo Executivo e Legislativo, será realizado o planejamento energético global, cabendo à EPE a responsabilidade de "elaborar os planos setoriais e, em particular,

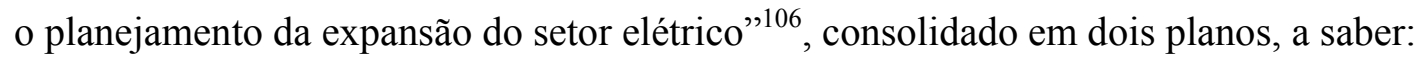

a) Plano de Expansão de Longo Prazo - PELP, cobrindo horizonte não inferior a 20 anos;

b) Plano Decenal de Expansão - PDE, cobrindo horizonte não inferior a 10 anos, tendo caráter determinativo.

Com essa lógica, os dois planos acima especificados serão submetidos a processos públicos de contestação ${ }^{107}$, viabilizando, segundo o governo federal, o atendimento de três objetivos básicos: eficiência alocativa; transparência e modicidade tarifária. De fato, para que esses objetivos possam ser plenamente alcançados, a lógica de mercado deve ser substituída pela de planejamento, de maneira a garantir a reestruturação setorial, preservando a integração total do sistema, em especial por se tratar da expansão de um serviço público.

Completando o processo de planejamento setorial, também, está sendo previsto o monitoramento das condições de atendimento eletro-energético, cobrindo um horizonte de 5 anos, a ser executado, como explicitado no Quadro 3.1, pelo CMSE, sob coordenação do MME, com a participação dos diferentes agentes setoriais. Focado em um ciclo permanente de atividades, esse monitoramento permite identificar eventuais ajustes no programa de expansão, de forma a garantir a suficiência da oferta, no curto prazo.

Como forma de permitir que os benefícios da competição sejam transferidos para os consumidores finais, estão sendo defendidos procedimentos licitatórios tanto para empreendimentos individualizados quanto para parcela de consumo previsto de energia elétrica. No primeiro caso, o documento esclarece que, a menor receita para o empreendedor, observado um teto de receita estabelecido pela CCEE, será a proposta

\footnotetext{
${ }^{106}$ Ministério de Minas e Energia (2003, p. 14)

${ }^{107}$ Conforme esclarece o texto do MME (2003, p. 18), o objetivo de submeter à contestação pública os planejamentos de longo e médio prazo permite que os atores da sociedade, direta ou indiretamente interessados, como concessionários, universidades, movimentos sociais, consumidores e investidores tenham a oportunidade de se manifestar sobre: "as premissas utilizadas nos estudos (por exemplo, crescimento da economia, previsão da demanda por energia); a estratégia escolhida para a expansão do sistema; a metodologia de planejamento utilizada; e o plano de expansão propriamente dito (por exemplo, possibilidades de expansão da oferta não consideradas ou descartadas)".
} 
vencedora. Já no segundo caso, a(s) proposta(s) vencedora(s) será(ão) aquela(s) que combine $(\mathrm{m})$ os empreendimentos oferecidos pelo proponente que atendam ao mercado com menor receita requerida, utilizando "como referência para o cálculo da máxima receita requerida, os custos de energia indicados nos estudos de planejamento para o ano de entrada das usinas". ${ }^{108}$

Outro ponto ressaltado no texto refere-se à revisão periódica da receita do gerador. De acordo com a proposta, como forma de garantir o equilíbrio econômico-financeiro do contrato, a cada 5 anos, será realizado processo de revisão, devendo a EPE publicar mensalmente os indicadores de variação de custos setoriais, visando subsidiar esse processo. O documento do MME explicita que, "não será utilizado um índice de reajuste geral como, por exemplo, o IGP-M"109, porém, para efeito da revisão, serão medidos os desvios do índice de reajustes, assumidos quando da licitação, e a variação dos custos efetivos de cada empreendimento (mão-de-obra, material, capital etc), cabendo à EPE publicar, mensalmente, os indicadores de variação de custos setoriais, de modo a subsidiar a tomada de decisão.

Ademais, o arranjo proposto parte do pressuposto de que a operação coordenada e centralizada do sistema hidrelétrico brasileiro proporciona significativos ganhos energéticos. Dessa forma, o MME defende a manutenção do despacho centralizado das usinas e a utilização coordenada e com segurança do sistema de transmissão, sob coordenação do ONS, visando atender à carga com nível adequado de qualidade e confiabilidade. Entretanto, de forma a garantir que as decisões de operação sejam sempre transparentes e desvinculadas dos interesses comerciais dos agentes, a proposta pressupõe que o ONS paute suas ações segundo "Procedimentos de Rede" submetidos a processo de audiência pública e aprovados pela ANEEL.

Dessa forma, de um lado, a ONS deverá divulgar, com freqüência mensal, indicadores de desempenho realizado, tais como, segurança operativa, níveis de perdas, nível de encargos de serviços de sistema, e desvio nas previsões operativas, e de outro, a

\footnotetext{
${ }^{108}$ Ministério de Minas e Energia (2003, p. 20).

${ }^{109}$ Ao utilizar um índice específico par o setor elétrico, o governo federal procura reproduzir de forma mais adequada o comportamento dos custos do setor, diminuindo distorções no processo de revisão das receitas das empresas de geração.
} 
ANEEL deverá promover, anualmente, auditoria nos sistemas e procedimentos técnicos do ONS, visando verificar e divulgar relatório propondo melhorias para os seguintes aspectos: confiabilidade e integridade dos sistemas operacionais utilizados; aderência das práticas operativas aos Procedimentos de rede; e a qualidade e atualidade técnica dos sistemas e processos.

Quanto à contratação dos serviços de geração de energia, o arranjo proposto, conforme devidamente explicitado pelo MME, reconhece todos os organismos e instituições que atuam no sistema elétrico brasileiro, à exceção do Mercado Atacadista de Energia - MAE, que foi substituída pela Câmara de Comercialização de Energia Elétrica CCEE. Isto porque, o novo modelo de contratação dos serviços de geração deverá abranger tanto o sistema interligado quanto os sistemas isolados, visando a assegurar a modicidade tarifária para os consumidores finais, bem como a viabilidade econômico-financeira dos geradores e distribuidores que neles atuam, ou vierem a atuar.

Assim, o modelo desenhado propõe a coexistência de dois ambientes de contratação, a saber:

a) Ambiente de Contratação Regulada (ACR), denominado por simplicidade de ambiente pool, que terá tarifas de suprimento reguladas, através da compra da energia pelo conjunto das distribuidoras, em leilões, por diversos prazos, de maneira a proteger os consumidores cativos, atendidos pelas distribuidoras. Neste ambiente, todos os geradores, incluindo produtores independentes, venderão energia para todas as distribuidoras, por meio da CCEE. Os leilões de energia existente serão separados dos leilões de expansão.

b) Ambiente de Contração Livre (ACL) - onde geradoras e produtores independentes comercializarão energia, com preços e quantidades livremente negociados, com os consumidores livres, pela legislação representando aqueles que têm demanda superior à 3MW, visando estimular a iniciativa de tais consumidores. Ressalte-se que a figura do comercializador de energia foi preservada no novo modelo, mas com atuação restrita no ACL.

A Figura 3.2. busca caracterizar o mercado desenhado para o segmento competitivo de geração, que permite a convivência dos dois ambientes acima destacados, quais sejam: 
Ambiente de Contratação Regulada - ACR (pool) e o Ambiente de Contratação Livre ACL.

\section{GERAÇÃO COMPETITIVA}

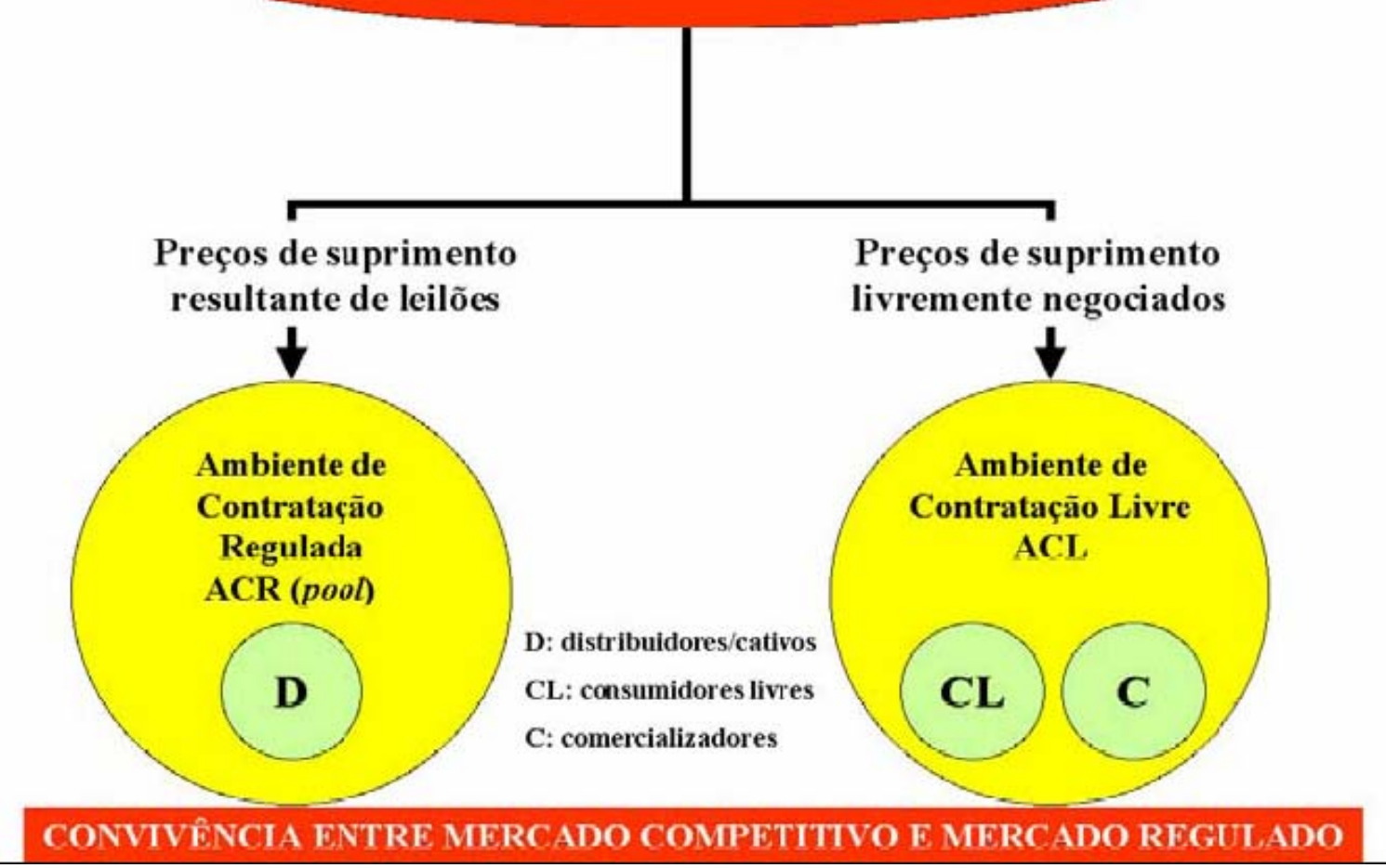

Figura 3.2.

Convivência do Mercado Regulado e do Mercado Competitivo

Fonte: Ministério das Minas e Energia

Completando o modelo competitivo de geração, a proposta sugerida pelo MME prevê que a contratação de energia para atender o consumo seja feita através de licitações.

Assim, de um lado, anualmente serão realizadas licitações para contratação de energia existente, cujos contratos serão iguais aos atuais, ou seja, do tipo bilateral, com diferentes prazos de duração, entre cinco e dez anos.

De outro, a contratação de energia de novas plantas geradoras, embora também realizadas através de licitação, dar-se-á em duas fases, a saber: a) licitação inicial, realizada com cinco anos de antecedência, visa contratar energia para atender a uma dada previsão de crescimento da demanda; e b) licitação complementar, realizada com três anos de 
antecedência (dois anos após a licitação inicial), para contratação de acréscimos de demanda decorrentes de revisão da projeção utilizada na licitação inicial.

Em ambas às situações, caberá ao MME oferecer um conjunto de projetos de empreendimentos (hidrelétricos e termoelétricos) estudados pela Empresa de Pesquisa Energética - EPE e considerados os mais econômicos para atendimento da demanda. Com o objetivo de aumentar a eficiência do processo de licitação, o montante total de capacidade (energia assegurada) dos projetos ofertados será maior que a demanda prevista e por ordem de preços crescentes, visando incentivar a competição por usinas mais eficientes.

A Figura 3.3. tenta descrever este mecanismo licitatório, sinalizando, inclusive, que em casos especiais, o Conselho Nacional de Política Energética - CNPE poderá autorizar a licitação por usinas individuais.

\section{TIPOS DE LICITAÇÃO}

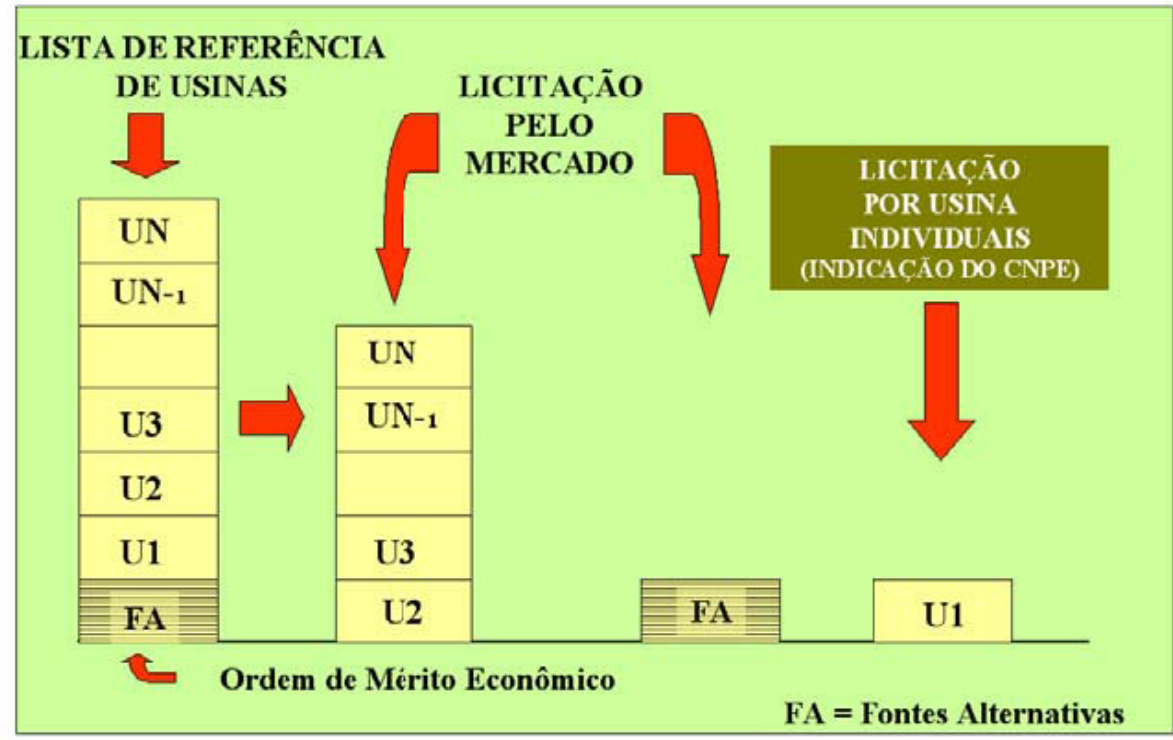

Figura 3.3. Mecanismos licitatórios

Fonte: Ministério das Minas e Energia (2005)

Com este conjunto de informações, foi possível caracterizar, em linhas gerais, o novo modelo institucional do setor elétrico brasileiro que, como visto no início do presente item, busca atingir três objetivos centrais, quais sejam: a) garantir a segurança de 
suprimento de energia elétrica; b) promover a modicidade tarifária, por meio da contratação eficiente de energia para os consumidores regulados; e c) promover a inserção social no setor, em particular pelos programas de universalização de atendimento.

Os resultados alcançados nos primeiros leilões de energia de empreendimentos existentes, respectivamente, em dezembro de 2004, abril e outubro de 2005, revelam que, dentre os objetivos acima explicitados, de fato, a modicidade tarifária vem sendo atingida com a utilização desse tipo de mecanismo licitatório, conforme se pode verificar no Quadro 3.4, abaixo explicitado.

Quadro 3.4

Resultados dos leilões de energia existente, realizados em 2004 e 2005

\begin{tabular}{|c|c|c|c|c|}
\hline $\begin{array}{c}\text { Data da realização/ } \\
\text { Característica dos produtos } \\
\text { leiloados }\end{array}$ & $\begin{array}{l}\text { Montante de } \\
\text { energia } \\
\text { negociado } \\
\text { (em MW } \\
\text { médios) }\end{array}$ & $\begin{array}{c}\text { Preços } \\
\text { Iniciais } \\
\text { (médios) } \\
\text { em } \\
\text { R\$/MWh }\end{array}$ & $\begin{array}{c}\text { Preços } \\
\text { Finais } \\
\text { (médios) } \\
\text { em } \\
\text { R\$/MWh }\end{array}$ & $\begin{array}{l}\text { Variação } \\
\text { conseguida } \\
\text { (em \%) }\end{array}$ \\
\hline $\begin{array}{l}\text { - Dezembro/2004 } \\
\text { (1 }{ }^{a} \text { leilão de energia existente) }\end{array}$ & & & & \\
\hline 8 anos: $01 / 01 / 2005$ á $31 / 12 / 2012$ & 9.054 & 80,00 & 57,51 & $-28,11$ \\
\hline 8 anos: $01 / 01 / 2006$ à $31 / 12 / 2013$ & 6.782 & 86,00 & 67,33 & $-21,70$ \\
\hline 8 anos: $01 / 01 / 2007$ à $31 / 12 / 2014$ & 1.172 & 93,00 & 75,46 & $-18,86$ \\
\hline $\begin{array}{l}\text { - Abril/2005 } \\
\left(2^{\circ} \text { leilão de energia existente) }\right.\end{array}$ & & & & \\
\hline 8 anos: $01 / 01 / 2008$ à $31 / 12 / 2015$ & 1.325 & 99,00 & 83,13 & $-16,03$ \\
\hline 8 anos: $01 / 01 / 2009$ à $31 / 12 / 2016$ & sem negociação & & & \\
\hline $\begin{array}{l}\text { Outubro/2005 } \\
\text { (3\% } 4^{\circ} \text { leilões de energia existente) }\end{array}$ & & & & \\
\hline 3 anos: $01 / 01 / 2006$ à $31 / 12 / 2008$ & 102 & 73,00 & 62,95 & $-13,77$ \\
\hline 8 anos: $01 / 01 / 2009$ à $31 / 12 / 2016$ & 1.167 & 96,00 & 94,91 & $-1,14$ \\
\hline
\end{tabular}

Fonte: CCEE. Elaboração própria.

O êxito, entretanto, desse mecanismo para os próximos leilões nos quais a energia nova deverá ser negociada, depende, ainda, da confiança depositada pelos agentes nessa forma de contratação, em especial, dado o receio de que a energia contratada não possa ser plenamente assegurada, tendo em vista os diversos tipos de problemas relacionados à expansão da oferta de energia no País. 
Completando o capítulo, o próximo item mapeará as mudanças sugeridas quanto à atuação das agências reguladoras, no caso do presente trabalho, especificamente para a ANEEL, e de que forma tais transformações serão capazes de contribuir para o atendimento dos objetivos acima relatados.

\subsection{A proposta de mudança na legislação relativa às agências reguladoras: o Projeto de Lei $n^{0} 3.337 / 2004$}

No bojo do processo de reestruturação do setor elétrico brasileiro, ganha destaque o papel a ser assumido pelas agências reguladoras nesse novo ambiente. Conforme destacado no item 3.2. A reestruturação do setor elétrico e sua regulamentação básica: da Lei $n^{\circ}$ 8.631/93 à Lei no 9.648/98, desde dezembro de 1996, com a promulgação da Lei 9.427/96, a ANEEL foi instituída com a tarefa de tornar-se órgão regulador do setor em nível federal, de maneira a proporcionar as condições favoráveis ao desenvolvimento do mercado de energia elétrica e garantir o equilíbrio entre os agentes e em benefício da sociedade.

$\mathrm{Na}$ verdade, com a introdução de um órgão regulador independente, que ao contrário do antigo DNAEE, não está subordinado, mas apenas vinculado ao ministério, e deve, portanto, obediência apenas às leis e políticas delas decorrentes, esperava-se "proteger consumidores e agentes do abuso do poder de mercado, garantindo rentabilidade adequada aos investidores que atuem de forma eficiente, e protegendo consumidores e investidores de eventuais 'oportunismos' políticos"110.

Entretanto, dada, em parte, à complexidade da reestruturação proposta para o setor e à fragilidade do ambiente regulatório e institucional, em especial quanto à alocação de tarefas e responsabilidades entre os agentes públicos envolvidos, cujos argumentos centrais foram tratados nas páginas anteriores, a ANEEL não conseguiu cumprir adequadamente sua missão, tendo recebido diversas críticas quanto aos seus posicionamentos.

Desse modo, desde a época de campanha, o Presidente Luis Inácio Lula da Silva em nenhum momento disfarçou sua insatisfação quanto à excessiva autonomia dada às agências reguladoras, razão pela qual, logo ao assumir a Presidência da República, solicitou ao então Ministro Chefe da Casa Civil, que elaborasse um Projeto de Lei - PL, com o

\footnotetext{
${ }^{110}$ Pedrosa $(2005$, p.4)
} 
objetivo de rever o papel de todas as agências.

Assim, em 13 de abril de 2004, em meio a diversas manifestações por parte de representes do governo quando à necessidade de se estancar o processo de "terceirização das atividades do governo" criada durante o governo do Presidente Fernando Henrique Cardoso, foi encaminhado à Câmara dos Deputados para apreciação, o Projeto de Lei $\mathrm{n}^{\circ}$ 3.337/04, visando redefinir as regras aplicáveis às agências reguladoras, relativamente à sua gestão, organização e mecanismos de controle social.

Da leitura do texto original e de suas versões subseqüentes, cinco pontos merecem destaque, quais sejam:

a) Mandato de seus dirigentes: a proposta mantém a estabilidade dos dirigentes das agências reguladoras, durante o exercício de seus mandatos, de quatro anos, destacando, inclusive, que os mesmos só poderão perder seu mandato em caso de: i) renúncia; ii) condenação judicial transitada e julgada; e iii) processo administrativo disciplinar. Entretanto, o mandato para o DiretorGeral deve coincidir com o do Presidente da República. Essa estratégia, além de alterar a disposição definida anteriormente relativa a mandatos de quatro anos não coincidentes entre seus dirigentes, impede o convívio do DiretorGeral com diretores eleitos por outros governos, o que tem sido a conduta predominante na configuração das agências. Apesar disso, define regras destinadas a organizar o processo de decisão das agências, enfatizando seu caráter colegiado, o que poderá contribuir para a dinâmica interna.

b) Poder Concedente: o poder volta ao Ministério das Minas e Energia, que passará a promover as licitações destinadas à contratação de concessionários de serviço público para produção, transmissão e distribuição de energia elétrica e para a outorga de concessão para aproveitamento de potenciais hidráulicos, bem como a celebrar os contratos de concessão ou de permissão de serviços públicos de energia elétrica e de concessão de uso de bem público. A proposta, porém, possibilita, a critério do Ministério das Minas e Energia, delegar tais atos à ANEEL. Com isso, o governo federal preocupa-se, corretamente, em delegar ao Ministério das Minas e Energia as decisões 
diretamente relacionadas às políticas do setor e à agência apenas as atividades e funções de natureza técnico-operacional.

c) Relatórios de atividades: será necessária, anualmente, a elaboração de relatório de circunstanciados das atividades realizadas pela agência reguladora, de maneira a destacar o cumprimento da política do setor, definida pelos poderes legislativo e executivo, com o devido encaminhamento ao Ministério das Minas e Energia, ao Senado Federal e à Câmara dos Deputados, com a disponibilização ao público. Essa medida vem reforçar a preocupação de se garantir instrumentos públicos de acompanhamento das atividades exercidas pela agência, devendo ser entendida como um dos principais aspectos positivos propostos.

d) Contratos de gestão e de desempenho: deverá ser firmado, no prazo máximo de 120 dias, após a nomeação do Diretor-Geral, ouvidos previamente os Ministros de Estado da Fazenda e do Planejamento, Orçamento e Gestão, e após apreciação do Conselho de Política Energética, o contrato de gestão e de desempenho, que será o instrumento de acompanhamento da atuação administrativa da ANEEL e da avaliação de seu desempenho, com o objetivo de: i) aperfeiçoar o acompanhamento da gestão, promovendo maior transparência e controle social; e ii) aperfeiçoar as relações de cooperação, supervisão e fiscalização com o Poder Público, em particular no cumprimento das políticas públicas definidas para o setor. Cumpre lembrar que a Lei 9.427/96, que instituiu a ANEEL, já previa, em seu artigo $7^{\circ}$, o estabelecimento de um contrato de gestão, no prazo máximo de 90 dias, após a nomeação de seu Diretor-Geral, como sendo o instrumento de controle de atuação administrativa da autarquia e da avaliação de seu desempenho. A diferença, entretanto, que parece estar sendo sinalizada com a nova legislação, é a possibilidade de se permitir algum tipo de ingerência técnica e regulatória nos atos da agência. Isto porque, antes da assinatura do referido contrato, deverão ser "ouvidos" os Ministros de Estado da Fazenda e do Planejamento, Orçamento e Gestão, e somente após apreciação do Conselho de Política Energética, é que o mesmo poderá ser assinado. Além disso, passa a existir a 
obrigatoriedade de se especificar, no contrato de gestão e de desempenho, os seguintes aspectos: $i$ ) metas de desempenho administrativo e de fiscalização a serem atingidas, prazos de consecução e respectivos indicadores e os mecanismos de avaliação que permitam quantificar, de forma objetiva, seu alcance; ii) estimativa dos recursos orçamentários e o cronograma de desembolso de recursos financeiros necessários ao alcance das metas pactuadas; iii) obrigações e responsabilidade das partes em relação às metas definidas; iv) sistemática de acompanhamento e avaliação, contendo critérios, parâmetros e prazos; $v$ ) medidas a serem adotadas em caso de descumprimento injustificado das metas e obrigações pactuadas; vi) período de vigência; e vii) condições de revisão e renovação. Com isso, parece estar sendo comprometida à independência da agência, em especial no que se refere ao seu caráter fiscalizador e de autonomia financeira, passando a ser tratada como mais uma unidade orçamentária dentro do corpo organizacional do Executivo, passível de fiscalização. Neste particular, cabe questionar de que forma e quais serão os parâmetros que deverão auxiliar no processo de avaliação das metas de desempenho, e quem poderá arbitrar sobre o descumprimento de tais metas e obrigações e seus eventuais impactos sobre o cronograma de desembolsos de recursos orçamentários? Sem mencionar para o fato de que as próprias estatais federais, pertencentes, portanto, à União, também deverão ser objeto de fiscalização por parte das entidades reguladoras e poderão tornar-se objeto de pressão. Na verdade, os termos propostos da Seção II - Do Contrato de Gestão e de Desempenho, do referido PL, passa a impressão de que as atividades e as decisões da agência poderão estar constantemente sob fiscalização do governo federal, desfigurando a relação de independência da mesma, abrindo inclusive a possibilidade de que seja capturada, não mais pelo setor privado, mas sim por um dos representantes do próprio setor público.

e) Ouvidoria: está sendo proposta a criação, em cada um das agências reguladoras, de uma Ouvidoria, que atuará junto ao Conselho Diretor, sem subordinação hierárquica, sendo suas atribuições exercidas sem o acúmulo com outras funções. O Ouvidor será nomeado pelo Presidente da República 
para mandato de dois anos, podendo ser reconduzido por mais uma vez, cabendo a esse a função de zelar pela qualidade dos serviços prestados pela ANEEL e acompanhar o processo interno de apuração das denúncias e reclamações dos usuários, seja contra a atuação dela ou contra a atuação dos entes regulados. Além disso, o Ouvidor, de acordo com a proposta, terá acesso a todos os assuntos e contará com o apoio administrativo de que necessitar, competindo-lhe produzir, semestralmente e quando julgar oportuno, apreciações sobre a atuação da Agência Reguladora, encaminhando-as às diversas instâncias afetas, tais como o titular do Ministério das Minas e Energia, da Fazenda, do Planejamento, Orçamento e Gestão, o Chefe da Casa Civil, além das Comissões de Fiscalização e Controle da Câmara dos Deputados e do Senado Federal, com direito ao conhecimento geral, após a publicação de tais apreciações. Essa proposta, quanto associada à anterior, qual seja, de formalização de um contrato de gestão e de desempenho, reforça, ainda mais, a possibilidade de controle do Executivo sobre a agência. Neste caso, outro desafio se coloca: o de definir com precisão o perfil, ou melhor, o tipo de qualificação a ser exigido do ouvidor para que tenha condições efetivas de avaliar com qualidade as decisões da ANEEL, dada à complexidade do ambiente regulado e das matérias relacionadas?

Do exposto, parece ficar evidente que as mudanças formuladas pela atual gestão na legislação relativa às agências reguladoras, revelam sua preocupação em garantir algum tipo de controle sobre as mesmas, de maneira a cercear sua autonomia, tendo em vista o entendimento quase que predominante na atual gestão, de que as agências, sem um acompanhamento direto do Poder Executivo, acabam atuando muito mais a favor dos interesses privados do que públicos ou dos usuários. A falha, no entanto, parece centrar-se no próprio conceito do papel a ser assumido não apenas pela agência, mas também pelos demais agentes, sejam eles públicos ou privados, no novo modelo institucional estabelecido para cada segmento da infra-estrutura brasileira e, em particular, do setor elétrico.

Como registrado nos capítulos anteriores da presente tese de doutorado, a introdução de um órgão regulador independente surge em decorrência do próprio modelo de desverticalização do setor elétrico brasileiro, conduzido ao longo da década de 90 . Ao 
prever a necessidade de entrada de diversos agentes no setor, a ANEEL foi criada com o missão de responder extra-mercado e de forma independente, os conflitos de interesse dos agentes envolvidos, tais como consumidores, governo e empresas, de maneira a proteger tanto os usuários quanto os investidores.

Entretanto, a complexidade do modelo, a falta de clareza institucional e a necessidade de se encaminhar e atrair investidores privados, tendo em vista a motivação predominantemente fiscal que orientou os processos de privatização conduzidos à época, comprometeram, como já enfatizado anteriormente, não apenas a precisa definição do melhor modelo a ser formulado para o setor elétrico brasileiro, mas também um cronograma adequado para a implantação de tais mudanças.

Ademais, a ausência de uma política energética clara e a opção de se transferir ao setor privado a decisão de investimento, minimizando a função do Estado como planejador deste segmento da infra-estrutura nacional, possibilitou o fortalecimento da ANEEL, em especial dado o vácuo de poder não assumido, em particular, pelo Ministério das Minas e Energia.

Concluindo, percebe-se que não se deve transferir apenas para a ANEEL a responsabilidade de sua expressiva atuação e dos eventuais riscos de captura a que foi submetida. Na verdade, ela também é fruto, tanto da reestruturação formulada, que ao desaparelhar o antigo DNAEE, instituiu uma nova entidade formada em parte por seus antigos funcionários ou por aqueles advindos das empresas desestatizadas, quanto da omissão dos principais agentes públicos atuantes no modelo e da complexidade do próprio ambiente regulado, que requer muito mais do que simples informações técnicas do setor, mas uma densidade de conhecimento, abrangência e multidisciplinariedade, ainda em fase de construção no País.

Assim, muito mais do que realizar sucessivos contingenciamentos de seu orçamento, como se revelou ser a prática da atual gestão, quando, a partir de 2003, foi repassado apenas $\mathrm{R} \$ 44,506$ milhões em recursos da TFSEE às agências estaduais de regulação em energia, representando uma redução de $40 \%$ em comparação ao total de $\mathrm{R} \$$ 74,3 milhões inicialmente previsto para o período 2003-2005 (ver Tabela 3.8), e/ou esvaziar a ação das agências ao demorar na indicação de seus diretores, ou até mesmo, 
instituir formas de controle de gestão e de acompanhamento de seu desempenho, que muitas vezes poderão assumir condutas arbitrárias, seria mais conveniente privilegiar a independência técnica e financeira da ANEEL, com a manutenção dos contratos de gestão e o aparelhamento qualificado de seu corpo técnico.

Tabela 3.8.

Valores previstos e repassados

2003-2005

\begin{tabular}{|c|c|c|}
\hline Ano & $\begin{array}{c}\text { Valores } \\
\text { Previstos } \\
\text { (R\$ milhões) }\end{array}$ & $\begin{array}{c}\text { Valores } \\
\text { Repassados } \\
\text { (R\$ milhões) }\end{array}$ \\
\hline 2003 & 25,338 & 11,891 \\
\hline 2004 & 24,223 & 13,900 \\
\hline 2005 & 24,720 & 18,715 \\
\hline TOTAL & $\mathbf{7 3 , 9 8 1}$ & $\mathbf{4 4 , 5 0 6}$ \\
\hline
\end{tabular}

Fonte: ANEEL (2005, p.13)

Ao enfatizar essa sugestão de conduta, poderia estar sendo garantida a sua adequada atuação, e em paralelo, dar continuidade ao fortalecimento do Ministério das Minas e Energia no exercício de seu poder concedente e na formulação de políticas para o setor energético, criando as condições efetivas para que a ANEEL, assim como às demais agências reguladoras existentes nos diversos estados brasileiros, possam cumprir sua missão, qual seja, mediar, regular e fiscalizar o funcionamento do sistema elétrico, envolvendo o cumprimento das normas do marco regulatório em geral e das obrigações dispostas nos atos de outorga (contratos de concessão, autorização ou permissão) dos serviços de geração, transmissão e distribuição.

Com isso, estaria sendo resgatada a preocupação primária do sistema regulatório de criar mecanismos de incentivo, capazes de influenciar as ações dos agentes envolvidos, minimizando as falhas na operação dos mercados, expressas em termos de externalidades, de poder e de assimetrias de informações, de maneira a alcançar padrões de qualidade dos serviços oferecidos e de eficiência produtiva, além de impedir a discriminação entre os consumidores, visando o bem-estar da sociedade, objetivos claramente perseguidos no "novíssimo" modelo institucional do setor elétrico brasileiro. 


\section{CAPÍTULO 4: SETOR ELÉTRICO E POLÍTICA INDUSTRIAL: uma estratégia de articulação para o Brasil}

\subsection{Introdução}

Do exposto até o momento, parece ficar clara a importância de se construir um quadro institucional e um marco regulatório estáveis, como elementos essenciais para o bom encaminhamento de qualquer processo de reestruturação setorial nas áreas de infraestrutura, particularmente para o setor elétrico.

De fato, as mudanças experimentadas em diversos países, em especial durante a década de 90, reforçaram, como estratégia, a busca pela construção de um ambiente setorial mais competitivo, na tentativa de assegurar eficiência econômica pelo próprio mercado, reduzindo, assim, a necessidade de um planejamento estratégico. Em paralelo, como forma de contornar eventuais falhas de mercado, ganham força às agências reguladoras que, de maneira independente, passaram a "zelar" pelo sucesso da estratégia liberal. Com essa estrutura, ter-se-ia assegurada a expansão da oferta de energia.

A virada do século XXI, entretanto, revela a necessidade de se "reconhecer os limites concretos da construção institucional de mercados competitivos na indústria elétrica" ${ }^{\prime 11}$. Na verdade, aos poucos o Estado, pelo menos do que foi exposto no capítulo anterior, particularmente no item 3.4 do capítulo anterior, parece estar buscando resgatar seu espaço na rearticulação do quadro institucional, em meio a um novo processo de reestruturação do setor, de maneira a sair fortalecido na coordenação da política energética nacional, tendo em vista o fracasso da tentativa anterior de se transferir totalmente à iniciativa privada a responsabilidade pelo planejamento setorial.

Em paralelo, o próprio debate, que antecedeu às eleições de 2002, evidenciou a necessidade de se estabelecer uma nova estratégia de desenvolvimento nacional, capaz de impulsionar, através de uma ação governamental organizada, o que Coutinho (2006) denominou, "um ciclo vigoroso de investimentos em infra-estrutura e em criação de nova capacidade produtiva", de maneira a responder à crise do padrão perseguido durante os anos 90, que restringiu à praticamente zero a possibilidade de se pensar qualquer outra combinação de política econômica interna, que não fosse àquela ditada pela cartilha do

\footnotetext{
${ }^{111}$ Pinto Jr. e Bicalho (2004, p. 8)
} 
"Consenso de Washington", sem desmerecer, obviamente, o êxito conseguido pela estabilidade monetária, quando da implantação do Plano Real.

Nesta linha, ganha espaço dentro da discussão de políticas públicas, a formulação, por exemplo, de uma política industrial nacional, que, dentre seus diversos objetivos, buscasse aliviar a restrição externa, sempre recorrente como um dos pontos de constrangimentos das economias emergentes, focando seu empenho no "aumento do volume de comércio exterior - através, sobretudo, da ampliação da competitividade da estrutura produtiva do país"112. Para isso, o desenvolvimento da matriz produtiva de setores dinâmicos disseminadores de inovação tecnológica, bem como a exportações de cadeias competitivas, poderiam se transformar em metas a serem perseguidas, estimulando não apenas novos mercados, mas a criação de oportunidades internas.

De fato, quando se analisa o trabalho intitulado "Diretrizes de Política Industrial, Tecnológica e de Comércio Exterior", divulgado em novembro de 2003, por representes do Governo Lula, percebe-se que essa preocupação estava presente. Isto porque, o próprio documento enfatiza a prioridade de se buscar "uma maior inserção do país no comércio internacional, estimulando os setores onde o Brasil tem maior capacidade ou necessidade de desenvolver vantagens competitivas, abrindo caminhos para inserção nos setores mais dinâmicos dos fluxos de troca internacionais". ${ }^{113}$ Assim, no curto prazo, a Política Industrial, Tecnológica e de Comércio Exterior - PITCE, como passou a ser identificada, pretendia "diminuir as restrições externas do país e, no médio e longo prazo, equacionar o desenvolvimento de atividades-chave, de modo a gerar capacitações que permitam ao Brasil aumentar sua competitividade no cenário internacional" ${ }^{, 14}$.

Infelizmente, os resultados desta estratégia ainda não podem ser avaliados, conforme será destacado nos parágrafos seguintes, porém, mantida sua intenção, o próximo desafio seria tentar mapear de que modo o modelo de reestruturação do setor elétrico nacional, em curso no país, tem condições de contribuir nessa estratégia de desenvolvimento, que enfatiza como um de seus principais pilares, o comércio exterior.

Desse modo, o presente capítulo tem como preocupação inicial detalhar a forma

\footnotetext{
${ }^{112}$ Diretrizes de Política Industrial, Tecnológica e de Comércio Exterior, Ministério do Desenvolvimento, Indústria e Comércio Exterior, novembro/2003, p. 2.

${ }^{113}$ Idem, p. 2

${ }^{114}$ Idem, p. 10
} 
como o tema política industrial foi tratado no Brasil durante a década de noventa, e os efeitos desta orientação na pauta de exportação brasileira, para, na seqüência, analisar a opção delineada pelo governo do Presidente Luís Inácio Lula da Silva, por entender que essa proposta, embora em fase de implantação, sintetiza fortes eixos de atuação, passíveis de serem perseguidos, dado seu alinhamento com a preocupação acima caracterizada.

Por fim, espera-se levantar alguns pontos relacionados ao perfil da pauta de exportação brasileira, em particular sobre os bens vinculados aos setores eletrointensivos, e aos possíveis arranjos a serem conduzidos entre a "Política Industrial, Tecnológica e de Comércio Exterior" - PITCE e a recente reestruturação do setor elétrico.

\subsection{O enfoque dado ao tema "Política Industrial e de Comércio Exterior", durante o período compreendido entre 1990-2002, e seus efeitos na pauta de exportação brasileira.}

Conforme explicitado por Guimarães (1995, p. 20), a política industrial e de comércio exterior introduzida no início da década de noventa no Brasil, difere da "vigente nas décadas anteriores ao deslocar seu eixo central de preocupação da expansão da capacidade produtiva para a questão da eficiência e da competitividade, contemplando como objetivos prioritários, o aumento de produtividade, a redução de custos, a melhoria da qualidade dos produtos e o repasse desses ganhos ao consumidor”.

Como aponta o autor, a política anterior buscou atender duas linhas de ação, a saber:

a) uma política de concorrência, orientada para eliminar entraves ao aumento da eficiência do sistema produtivo, induzir as empresas à busca da competitividade e assegurar a transferência dos ganhos de eficiência ao consumidor, desdobrando essa política, por sua vez, em uma política de liberalização comercial e outra de concorrência estrito senso;

b) uma política de competitividade, destinada a apoiar as empresas em seus esforços para aumentar sua eficiência e a induzir as transformações requeridas na estrutura produtiva. Tal conduta necessita de uma atuação mais ativa do Estado, com a construção de vantagens comparativas, através da identificação contínua das "novas" vantagens a serem perseguidas. 
Evidentemente, que se verificam resultados mais expressivos na política de liberalização comercial, onde a atuação do Estado dá-se de maneira pontual, centrada na abertura da economia e na redução de tarifas alfandegárias. De fato, como bem coloca Erber (2002, p.644), a visão de desenvolvimento que prevaleceu durante aquele período acabou por excluir outra alternativa. Ao continuar sua argumentação Erber (2002, p. 644) sinaliza que,

“... segundo aquela visão, pautada pela agenda liberal radical, dois 'círculos virtuosos', entrelaçados levariam ao desenvolvimento, sem o auxílio de uma política industrial. $\mathrm{O}$ primeiro círculo dizia respeito à globalização, caracterizada como o crescimento do comércio e investimentos internacionais em níveis superiores ao da produção. Promovendo a abertura comercial, de investimentos e financeira, o país participaria deste processo, potencializado pela política de câmbio valorizado. A abertura comercial traria importações de bens de produção modernos, que levaria a um aumento de produtividade, permitindo no futuro, um aumento de exportações. O mesmo efeito seria alcançado pelo aumento dos investimentos diretos estrangeiros", o que levaria às empresas locais a modernizar-se pela competição (....) No segundo círculo virtuoso, a estabilidade de preços (garantida pela abertura) daria aos empresários um horizonte de longo prazo e um mercado ampliado pelo fim do imposto inflacionário, ensejando investimentos que aumentariam o produto e as exportações. A estes estímulos viriam somar-se o aumento da competição, trazido pelas importações, pela entrada de capitais estrangeiros e pela privatização, além do reforço das instituições de defesa da concorrência e dos consumidores".

Nessa visão de desenvolvimento, uma política industrial que exigisse uma atuação mais ativa do Estado, através do planejamento contínuo e integrado das diversas políticas públicas em curso, seria, como pondera Erber (2002, p. 645), “não só dispensável como contraproducente" 115 .

De qualquer modo, mesmo sem o apoio institucional do governo, as empresas passaram a incluir a "competitividade" em suas agendas, como integrante de suas estratégias de sobrevivência e crescimento, modernizando suas instalações e aumentando sua produtividade ${ }^{116}$, sem, contudo, desenvolver "sua capacidade de inovação tecnológica

\footnotetext{
115 O próprio ex-Ministro da Fazenda, Pedro Malan, em diversas oportunidades declarou que "a melhor política industrial é não ter política industrial", ao que tudo indica parafraseando um outro ex-Ministro da Fazenda, Roberto Campos. Seja como for, essa posição revela com bastante precisão a forma como a gestão do Presidente FHC encarava o tema política industrial.

${ }^{116}$ Neste particular, merece atenção especial o episódio de valorização do real vivenciado entre os anos de
} 
(que requer ativos distintos daqueles necessários para produzir com eficiência), assim como a capacidade de vendas no mercado internacional, que continua muito limitada”. ${ }^{117}$

Para ilustrar melhor os resultados comerciais do Brasil com o resto do mundo, pode ser usado o estudo realizado por Gonçalves (2004), que, ao analisar o padrão de comércio brasileiro no período que vai de 1990, ano em que se inicia o processo de liberalização da economia brasileira, com a posse do Presidente Fernando Collor de Mello, até 2002, com destaque para o efeito nas contas externas do ajuste macroeconômico implementado com a desvalorização cambial de janeiro de 1999, busca revelar a perda de competitividade e a reprimarização das exportações brasileiras, como sendo os dois principais resultados da ausência de uma estratégia clara de inserção mundial.

Ao qualificar suas conclusões esclarece que "a perda de competitividade internacional do conjunto das exportações deveu-se, exclusivamente, à perda de competitividade dos produtos manufaturados brasileiros no mercado mundial. Já o processo de reprimarização envolveu uma maior participação relativa dos produtos agrícolas no valor total das exportações brasileiras"118. Tais aspectos, conforme reforça o autor, compromete uma tendência de longo prazo de melhoria do padrão de comércio brasileiro relacionada a uma maior participação do Brasil no comércio mundial de produtos manufaturados que se reduziu de 0,76\%, em 1990-1994 para 0,69\% em 2000-2001. .

O autor acrescenta, ainda, que essa mudança no comportamento das relações comerciais com o resto do mundo gera uma dependência externa em relação ao mercado mundial de produtos primários, em especial, com àqueles intensivos em recursos naturais $\mathrm{e}$ em energia, com baixo grau de processamento. Assim, tem-se que dos 17 produtos de exportação, responsáveis por $46,9 \%$ do valor das exportações em 2002, havia 6 produtos manufaturados não tradicionais, que representaram 15,3\% do valor das exportações, 11 produtos eram primários, semi-manufaturados ou manufaturados tradicionais, representando 31,6\% das exportações, de acordo com estudo de Gonçalves (2004, p. 19).

1994 e 1998, conforme destacam Castro e Souza (2006), em artigo publicado na Folha de São Paulo, que permitiu a modernização da indústria brasileira, mediante absorção de novas técnicas produtivas e a incorporação de equipamentos importados, possibilitando um aumento de produtividade e uma melhoria nos processos produtivos internos.

${ }_{117}^{17}$ Erber (2002, p. 646).

${ }^{118}$ Gonçalves (2004, p.11) 
Ressalte-se, ainda, conforme demonstra o autor no mesmo trabalho,

“... a deterioração dos termos de troca da economia brasileira no contexto da forte presença de produtos intensivos em recursos naturais nas exportações brasileiras. Isto significa que o país tem exportado volumes cada vez maiores de recursos reais para obter menos produtos do exterior. Assim, a partir de 1999, o ajuste das contas externas tem se realizado não somente a custas do crescimento medíocre da renda e da elevação do desemprego, como também com maior impacto sobre a exploração de recursos naturais e, portanto, maiores efeitos sobre o meio ambiente" ${ }^{, 19}$.

A partir dessa última ponderação, qual seja, de que a melhoria nos resultados externos está relacionada à exploração de recursos naturais, trazendo maiores efeitos sobre o meio ambiente, torna-se relevante caracterizar tais segmentos da indústria extrativa nacional $^{120}$.

Conforme destacado por Bermann (2004), o setor produtivo eletrointensivo é responsável por $27 \%$ do consumo final de energia elétrica no Brasil, algo em torno de 85 mil MWh e, ao longo dos últimos anos, a produção brasileira desses setores industriais praticamente dobrou, como conseqüência de uma política de apoio e incentivo a esta forma de inserção no mercado internacional, baseada na produção para exportação de bens primários de baixo valor agregado ${ }^{121}$. Por outro lado, quando se avalia o número de postos de trabalhos criados, por unidade de energia consumida, percebe-se que patamar de empregos gerados nesses setores não é tão elevado: siderurgia 5,4 empregos/GWh; alumínio 2,7 empregos/GWh; e ferro-ligas 1,1 empregos/GWh ${ }^{122}$.

Além de tais informações, deve-se ter ciência, a partir das previsões de consumo de energia elétrica de tais setores industriais, indicadas no Relatório Analítico de MercadoCiclo 2000, elaborado pelo CCPE/CTEM (maio/2001), e apresentadas em Bermann, 2002(b), de que "no seu conjunto, os setores eletrointensivos estão empenhados num expressivo processo de aumento da escala de produção, o que torna crucial a questão do suprimento de energia elétrica necessário para atender esta crescente demanda".

\footnotetext{
${ }^{119}$ Gonçalves (2004, p.21).

${ }^{120}$ De acordo com Bermann (2002(a) fazem parte desse setor produtivo aquelas atividades que consomem muita energia, das quais destacam-se: siderurgia, responsável por $8 \%$ de toda a energia consumida, alumínio $(4,3 \%)$, papel e celulose $(3,5 \%)$ e ferroligas.

${ }_{121}$ Dados consolidados do BEN, ano-base 2000, 2001, extraídos de Bermann 2002(b).

${ }^{122}$ Bermann 2002(a), p. 84.
} 
Ressalte-se, ainda, que a crise energética de 2001 tornou o problema do suprimento para os ramos industriais eletrointensivos ainda mais agudo. Ilustrando essa informação, Bermann 2002(b), lembra que:

"BNDES mostrou que a indústria do alumínio no país, formada por sete grandes empresas, foi uma das mais afetadas com o racionamento. $\mathrm{O}$ estudo mostrou que elas têm restrita capacidade de autogeração de energia e são altamente dependentes da energia comprada de concessionárias estatais. A indústria do alumínio tem um índice de apenas $12,7 \%$ de autogeração, enquanto que os segmentos de estanho têm índice de $86,9 \%$, zinco com $76,3 \%$ e níquel-cobalto com $29,2 \%$ ".

Dessa maneira, o item 4.4, explicita como algumas empresas enquadradas neste segmento da indústria nacional, vem se adequando às mudanças da política energética, tendo em vista que, ao menos para tais setores, as políticas de incentivo às exportações, a desvalorização do real frente ao dólar e o aumento da demanda externa contribuíram para um expressivo crescimento, conforme destacado por Bermann (2006).

Antes, porém, torna-se importante qualificar um pouco mais as informações relativas ao debate sobre a reprimarização da pauta de exportação brasileira, que ganhou fôlego ao final da gestão do Presidente Fernando Henrique Cardoso, a partir dos melhores resultados alcançados pelos produtos primários em detrimento da participação dos produtos manufaturados no total exportado pelo Brasil, por ter aos poucos realimentado uma antiga discussão sobre o processo de desindustrialização nacional e a possibilidade de o país ser atingido pela nova "doença holandesa" 123 .

Neste particular, merece atenção especial o trabalho desenvolvido por Nassif (2006), que embora cauteloso em suas conclusões, ajuda a esclarecer a questão, ao analisar, além do conceito de desindustrialização à luz da teoria econômica, as principais evidências empíricas sobre as mudanças internas, bem como sobre o padrão de especialização internacional verificados na indústria brasileira.

De fato, ao avaliar apenas o comportamento das exportações industriais, divididas

\footnotetext{
${ }^{123}$ Conforme explica Cysne (2006), o termo tem origem na descoberta de gás natural na Holanda nos anos 60, o que valorizou sua moeda e, segundo alguns, teria sido responsável pela queda de suas exportações. Do ponto de vista técnico, o jargão refere-se a um processo de redução de crescimento gerado pela descoberta de recursos naturais exportáveis que, ao gerarem abundância de divisas externas, valorizariam a taxa de câmbio real e prejudicariam o crescimento e os aportes de tecnologia pelos setores exportadores tradicionais.
} 
por tipo de tecnologia ${ }^{124}$, o autor identifica dois subperíodos:

“o primeiro, de estagnação, referente ao período 1989-1999, em que as taxas de crescimento das vendas externas de bens industrializados brasileiros, por terem sido afetadas, principalmente, pela tendência de apreciação cambial (notadamente entre 1994-1998), foram extremamente baixas e inferiores às taxas de incrementos das exportações mundiais; o segundo, de boom, ocorrido no período pós-1999, em que as taxas médias anuais de crescimento foram expressivas das vendas externas de produtos industrializados brasileiros".

Os dados levantados por Nassif (2006, p. 28) explicitam claramente, não apenas essa periodização, mas também a expansão, com base na taxa de crescimento média anual, dos setores industriais com tecnologia baseada em recursos naturais, de 3,12\%, para os anos de 1989-1994, para 12,03\% para o período de 1999-2004, e de 18,35\%, para o biênio 2004 2005, quando se verifica, de um lado, taxas de câmbio reais excessivamente baixas (ou seja, forte apreciação da moeda brasileira em termos reais) e, de outro, o expressivo aumento de preços relativos, das principais commodities exportadas pelo país.

Em termos de participação setorial, enquanto o segmento da indústria com tecnologia baseada em recursos naturais representou nos anos de 1989, 1999 e 2005, respectivamente, $39,7 \%, 44,3 \%$ e $47 \%$, o segmento baseado em ciência, que poderia assumir o papel de disseminador da inovação, alcançou 3,80\%, 7,16\% e 4,86\% da participação total, em semelhante período, confirmando, dessa maneira, a mesma distribuição relativa.

Apesar de tais resultados, Nassif (2006, p. 27) prefere não afirmar que o Brasil esteja passando por um processo de desindustrialização, por entender que ainda não há um processo generalizado de mudança na realocação dos recursos produtivos e no padrão de especialização dos setores com tecnologias intensivas em escala, diferenciada e baseada em ciência para as indústrias tecnologicamente baseadas em recursos naturais e em trabalho.

Para evidenciar tal conclusão, o autor reclassificou as exportações, segundo a intensidade tecnológica, ou seja, produtos primários, manufaturados e outras transações, sendo que no caso dos manufaturados usou a seguinte divisão: i) baseados em recursos

\footnotetext{
${ }^{124}$ Para a elaboração de seu trabalho, o autor dividiu a indústria brasileira em cinco tipos específicos de tecnologia, quais sejam: i) Baseada em recursos naturais; ii) Intensiva em trabalho; iii) intensiva em escala: iv) diferenciada; e $v$ ) baseada em ciência
} 
naturais; ii) baixa tecnologia; iii) média tecnologia e iv) alta tecnologia. Dessa forma, concluiu que as vendas externas dos manufaturados no total das exportações brasileiras mantiveram a mesma participação em torno de 88\%, entre 1898 e 1999, porém, em 2004 e 2005, houve uma redução para o patamar de 85\%. Em contrapartida, a participação dos produtos primários manteve-se no mesmo nível, isto é, 11\%, entre o período de 1989 e 1999, tendo se elevado para 13\%, apenas em 2004 e 2005.

Por outro lado, quando se observa o comportamento das exportações dos produtos manufaturados baseados em recursos naturais verifica-se um crescimento médio anual de 4,50\% para o período compreendido entre 1989 e 1999, de 10,56\% para os anos de 19992004 e de $17,03 \%$ para o biênio 2004-2005.

Assim, embora ainda não se possa concluir que o processo de desindustrialização esteja acontecendo, pode-se suspeitar, usando as palavras do próprio autor, que,

"mantida a tendência de apreciação da moeda brasileira em termos reais nos próximo anos, potencializam-se, de fato, os riscos de desindustrialização no Brasil. No longo prazo, esse riscos podem ser majorados pela 'nova industrialização' da China, que seguirá produzindo mudanças profundas na divisão internacional do trabalho país".

A par de tais considerações, o próximo passo é avaliar a "Política Industrial, Tecnológica e de Comércio Exterior" - PITCE, divulgado em novembro de 2003, pelo menos com a preocupação de caracterizá-la, uma vez que do exposto, parece ficar evidente que, muito mais do que planos de longo prazo, a economia brasileira necessita, no momento, inovar a sua política monetária, fiscal e cambial, de maneira a criar as condições objetivas para que possa ser possível a estruturação de uma política industrial coerente com uma estratégia de capacitação tecnológica, de maneira a melhorar a inserção internacional do Brasil, em um futuro não muito remoto.

\subsection{A Política Industrial, Tecnológica e de Comércio Exterior - PITCE, divulgada em novembro de 2003}

O Presidente Luís Inácio Lula da Silva, ao final de seu primeiro ano de governo, divulgou um conjunto de medidas, que posteriormente passaram a representar a "Política Industrial, Tecnológica e de Comércio Exterior" - PITCE, entendida como um dos itens 
que compõem a estratégia de desenvolvimento apresentada no documento "Orientação Estratégica de Governo: Crescimento Sustentável, Emprego e Inclusão Social”, base de seu Plano Plurianual 2004-2007, estando, portanto, na visão da atual gestão, articulada com os investimentos planejados para a infra-estrutura e com o os projetos de promoção de promoção do desenvolvimento regional.

Partindo do entendimento de que, no curto prazo, é necessário reduzir as restrições externas do país, e, no médio prazo, gerar capacitação interna capaz de ampliar a competitiva brasileira no cenário internacional, o documento listou quatro pontos a serem perseguidos, os quais abaixo são reproduzidos:

- Sustentar a elevação do patamar das exportações, com a valorização de recursos e produtos brasileiros, aproveitando potencialidades para melhorar a imagem do País no exterior e ajudar a criar a "marca Brasil";

- Promover a capacidade inovadora das empresas via concepção, projeto e desenvolvimento de produtos e processos. Estimular o incremento de atividades portadoras de produtos de futuro, como biotecnologia, software, eletrônica e optoeletrônica, novos materiais, nanotecnologias, energia renovável, biocombustíveis (álcool, biodiesel) e atividades derivadas do Protocolo de Kyoto.

- Contribuir para o desenvolvimento regional, estimulando iniciativas que valorizem a dimensão espacial e o fortalecimento de arranjos produtivos locais.

- Desenvolver projetos voltados para o consumo de massa. Ainda que a demanda seja o indutor dos investimentos, o objetivo é estabelecer padrões de qualidade, design e conteúdo que possibilitem simultaneamente exportações para países com padrão de consumo e renda similares ao Brasil. Busca-se, com isso, auferir ganhos de escala e alcançar um padrão internacional de produto, reduzindo a dicotomia mercado de massas/mercado externo" ${ }^{\prime 25}$.

Cumpre destacar, ainda, que dentre as características básicas da política industrial e tecnológica, o estímulo à eficiência é visto em papel de destaque, tornando-se, inclusive,

\footnotetext{
${ }^{125}$ Idem p. 10.
} 
critério de avaliação dos resultados obtidos e de seleção dos beneficiários diretos. Ademais, o governo federal considerou cinco linhas de ação horizontais na implantação da referida política industrial, a saber:

- Inovação e desenvolvimento tecnológico: o documento enfatiza a necessidade de se estruturar um Sistema Nacional de Inovação - SNI, capaz de garantir a articulação entre os agentes, particularmente, empresas, centros de pesquisa públicos e privados, instituições de fomento e financiamento ao desenvolvimento tecnológico, instituições de apoio à metrologia, propriedade intelectual, gestão tecnológica e gestão do conhecimento, instituições de apoio à difusão tecnológica. Para se alcançar a esse objetivo, conforme destacado, tornase necessário harmonizar a base legal, fortalecer as instituições públicas e privadas envolvidas, de forma a criar uma rede de instituições especializadas em temas, setores e cadeias produtivas, inclusive com a estruturação de laboratórios nacionais, visando garantir a sinergia de pesquisa e desenvolvimento, de forma a transferir tecnologia e gestão para o setor produtivo. Por fim, completando as exigências relacionadas à estruturação desse SNI, o documento alerta para a necessidade de se aumentar a transparência do processo decisório e da ação governamental, com a divulgação sistemática dos resultados dos programas, envolvendo, também, a auditoria dos processos.

- Inserção Externa: as ações nesta área, conforme o documento, "voltam-se para a expansão sustentada das exportações e ampliação de base exportadora pela incorporação de novos produtos, empresas e negócios, incluindo: a) apoio às exportações, com financiamento, simplificação de procedimentos e desoneração tributária; b) promoção comercial e prospecção de mercados; c) estímulo à criação de centros de distribuição de empresas brasileiras no exterior e à sua internacionalização; d) apoio à inserção em cadeias internacionais de suprimentos; e) apoio à consolidação da imagem do Brasil e de marcas brasileiras no exterior" ${ }^{\prime 26}$.

- Modernização Industrial: o documento enfatiza três aspectos relativos a esta

${ }^{126}$ Idem, p. 13. 
linha de ação: a) definição de programas setoriais capazes de enfrentar o problema de capacitação produtiva e de gestão, de maneira articulada e simultânea; b) atuação dos programas de modernização devem priorizar os arranjos produtivos locais, privilegiando a dimensão regional, na busca de resultados mais ambiciosos; e c) incentivo à adoção de programas concentrados espacialmente, organizando sua ação de forma a atender um conjunto de empresas ao mesmo tempo.

- Capacidade e Escala Produtiva: destaca a necessidade de investir em setores que estejam no limite à capacidade instalada, tais como os produtores de bens intermediários, que por serem indústrias intensivas em capital, o período entre a tomada de decisão pelo investimento produtivo e o início de entrada em operação da nova planta industrial é relativamente longo. Como forma de assegurar que o investimento privado ocorra, o documento sugere a atuação do Estado de duas formas: a) aprovando instrumentos legais que facilitem a obtenção de financiamento por consórcios de empresas ou assemelhados; e b) estimulando a fusão de empresas ou a atuação conjunta para possibilitar desenvolvimento tecnológico e inovação cooperativas ou uma inserção mais ativa no comércio internacional.

- Opções Estratégicas: o documenta ressalta a importância de se concentrar esforços em algumas áreas intensivas em conhecimento, destacando atividades que: a) apresentam dinamismo crescente e sustentável; b) são responsáveis por parcelas expressivas dos investimentos internacionais em Pesquisa e Desenvolvimento; c) abrem novas oportunidades de negócios; d) relacionam-se diretamente com a inovação de processos, produtos e formas de uso; e) promovem o adensamento do tecido produtivo; e f) são importantes para o futuro do país e apresentam potencial para o desenvolvimento de vantagens comparativas dinâmicas. Enquadram-se nesses requisitos, de acordo com o entendimento do governo federal, os seguintes setores: semicondutores, software, fármacos e medicamentos e bens de capital.

Finalizando, o documento destacava que a coordenação e a operacionalização da 
presente PITCE seriam exercidas por grupos de trabalho de natureza interministerial, que iriam "acompanhar e monitorar mercados, empresas, setores, cadeia, arranjos produtivos, redes de empresas e firmas no cumprimento dos compromissos assumidos no âmbito dos programas" ${ }^{\prime 27}$, reportando-se a colegiados de Ministros.

Como visto, a PITCE, embora busque alinhavar um conjunto de medidas, com o objetivo de "induzir a mudança do patamar competitivo da indústria brasileira, rumo à maior inovação e diferenciação dos produtos, almejando competitividade internacional", seu alcance, do ponto de vista da formulação de políticas verticais, nos termos apresentados no item 1.3 Regulação Econômica e Políticas Públicas, ainda é muito tímido.

Por outro lado, apesar de tal limite, quando se avalia o documento Balanço PITCE 2005, elaborado pela Agência Brasileira de Desenvolvimento Industrial - ABDI, que faz uma síntese dos principais encaminhamentos e medidas já aprovadas no âmbito do programa, verifica-se, claramente, a preocupação do governo federal em criar, pelo menos, um ambiente voltado ao compromisso de desenvolvimento, mesmo que prevalecendo o vício de "almejar a competitividade internacional".

De fato, conforme se tenta apontar no Quadro 4.1., sem fugir de antigos receituários divulgados em governos passados, neste particular, ressalte-se, a redução de alíquotas de IPI e de importação, bem como a isenção de PIS/PASEP, em especial, sobre máquinas, equipamentos e produtos de informática, além de programas de apoio a $\mathrm{P} \& \mathrm{D}$, de inovação tecnológica nacional e de incubadoras, há espaço, em particular nas atividades portadoras de futuro, ainda em "fase de idéias", de se ampliarem às vantagens competitivas brasileiras, tendo em vista o potencial que áreas como biotecnologia, biomassa e biocombustíveis podem exercer em setores disseminadores de inovação diferenciada.

\section{Quadro 4.1.}

${ }^{127}$ Idem p. 22. 


\section{Sumário do PITCE}

Balanço 2005

\begin{tabular}{|c|c|}
\hline Linha de Ação & Principais Medidas \\
\hline $\begin{array}{c}\text { Ambiente } \\
\text { Institucional }\end{array}$ & $\begin{array}{l}\text { - ABDI - Agência Brasileira de Desenvolvimento Industrial - ABDI, foi criada } \\
\text { pela Lei } n^{\circ} 11.080 / 2004 \text { e regulamentada pelo Decreto } n^{\circ} 5.352 / 2005 \text {, com a } \\
\text { função de promover a execução de políticas de desenvolvimento industrial, } \\
\text { especialmente as que contribuam para a geração de empregos, em consonância } \\
\text { com as políticas de comércio exterior e de ciência e tecnologia. } \\
\text { O Conselho Deliberativo da agência será composto por oito representantes do } \\
\text { Poder Executivo (MDIC, MCT, MF, MPOG, MI, Casa Civil, BNDES e IPEA) } \\
\text { e sete da sociedade civil (CNI, APEX-Brasil, CNC, Sebrae, CUT, IEDI e } \\
\text { Anprotec). }\end{array}$ \\
\hline $\begin{array}{c}\text { Inovação e } \\
\text { Desenvolvimento } \\
\text { Tecnológico }\end{array}$ & $\begin{array}{l}\text { - "Lei do Bem”, } \mathrm{n}^{\circ} \text { 11.196/05 (antiga MP 255, conhecida como "MP do Bem"), } \\
\text { principais benefícios aprovados: } \\
\checkmark \text { isenção do PIS/PASEP para compra de máquinas e } \\
\text { equipamentos por empresas exportadoras, que exportam } 80 \% \text { da sua } \\
\text { produção; } \\
\text { isenção do PIS/PASEP e Cofins para os fabricantes de } \\
\text { computadores com valores de até R\$ } 2,5 \text { mil, visando reduzir o preço final } \\
\text { dos PC's em 10\%; } \\
\checkmark \quad \text { regime especial de tributação com abatimento em dobro das } \\
\text { despesas com pesquisa e desenvolvimento de novas tecnologias. } \\
\text { - Aporte de recursos para os Fundos Setoriais da ordem de R\$ } 755 \text { milhões, } \\
\text { sendo } 41 \% \text { destinado para bens de capital. } \\
\text { - Regulamentação da Lei de Inovação, em outubro/2005, objetiva criar um } \\
\text { ambiente propício às parcerias estratégicas entre universidades, institutos } \\
\text { tecnológicos e empresas. } \\
\text { - Programa Nacional de Incubadoras, do MCT } \\
\text { - Programa de Apoio a Pesquisas em Empresas, da FINEP } \\
\text { - Rede Brasil de Tecnologia - RBT, do MCT, que visa à substituição } \\
\text { competitiva das importações, focada para ampliar o potencial da indústria } \\
\text { nacional. } \\
\text { Programa de Desenvolvimento de Inovação - PDI, do BNDES, destinado às } \\
\text { empresas que investirem em P\&D de novas idéias. } \\
\text { - Programa de Inovação de Produção - IP, do BNDES, destinado a financiar } \\
\text { unidades para a fabricação dos produtos com base em inovação. }\end{array}$ \\
\hline $\begin{array}{c}\text { Inserção Externa } \\
\text { Ativa }\end{array}$ & $\begin{array}{l}\text { - Centro de Distribuição de Produtos Brasileiros: Miami está operando com } 97 \\
\text { empresas, os próximo serão Portugal, Alemanha e Emirados Árabes. } \\
\text { Em andamento o Programa Alerta Exportador, o Alerta Exportador (Sistema } \\
\text { Ampliado MERCOSUL) e o Programa de Superação de Barreiras Técnicas do } \\
\text { MERCOSUL, todos do Inmetro. }\end{array}$ \\
\hline $\begin{array}{l}\text { Modernização } \\
\text { Industrial }\end{array}$ & $\begin{array}{l}\text { - Redução de imposto de importação para máquinas e equipamentos sem } \\
\text { produção nacional. } \\
\text { - Regime Aduaneiro de Entreposto Industrial sob Controle Informatizado - } \\
\text { RECOF, o programa permite importar todos os insumos com suspensão de II, } \\
\text { IPI e PIS/Cofins; compras nacionais com a suspensão do IPI, dentre outros. } \\
\text { - Projeto de Extensão Industrial Exportadora - PEIEx e Arranjos Produtivos } \\
\text { Locais - APL's. } \\
\text { - MODERMAQ - Modernização do Parque Industrial Nacional, do BNDES, } \\
\text { destinado a financiar máquinas e equipamentos nacionais novos. } \\
\text { - Desembolsos do BNDES para o FINAME e Cartão BNDES }\end{array}$ \\
\hline Opções & - Semicondutores: Lei de Informática \\
\hline
\end{tabular}




\begin{tabular}{|c|c|}
\hline Estratégicas & 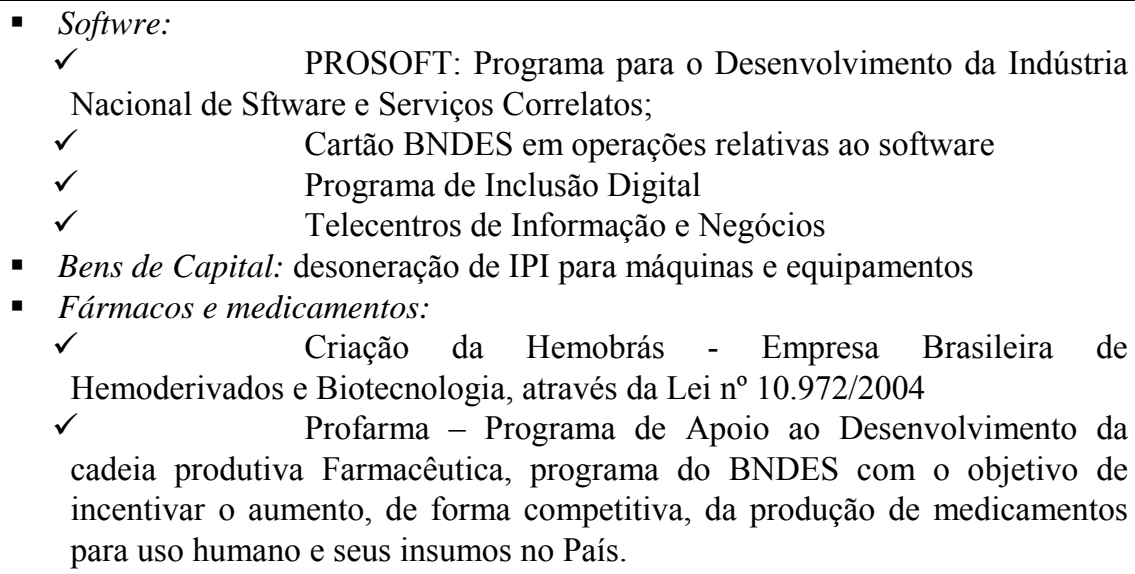 \\
\hline $\begin{array}{c}\text { Atividades Portadoras } \\
\text { de Futuro }\end{array}$ & 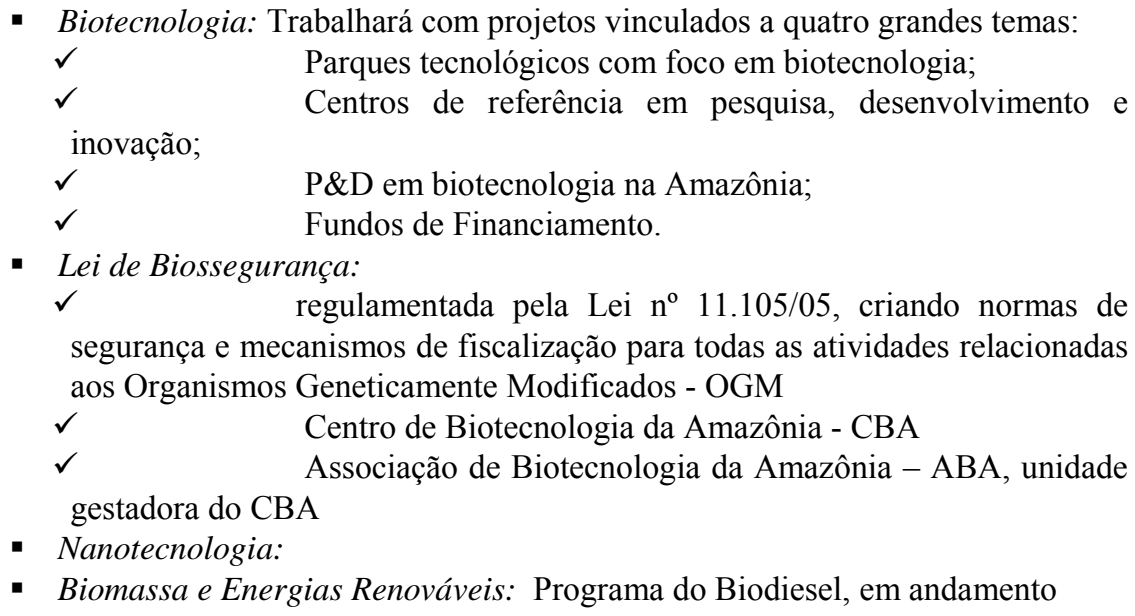 \\
\hline
\end{tabular}

Fonte: ABDI, Balanço PITCE (2005). Elaboração própria.

O desafio, contudo, passa pela determinação de transformar tais medidas não apenas em meras intenções, ou o que seria pior, simplesmente, em sinalizar o resgate do sempre presente conceito de "substituição de importações", visando ampliar o potencial da indústria nacional, como parece ser a intenção do programa "Rede Brasil de Tecnologia", acima destacado.

A real tarefa que se impõe é, de fato, transformar esse conjunto de metas em políticas ativas de governo, capazes de conduzir e orientar as demais políticas econômicas em curso, de maneira a fazê-las transitar, sintonizadamente, em direção a uma trajetória de desenvolvimento, como colocou Coutinho (2006), em recente artigo de opinião. Para isso, seria necessário adotar como estratégia prioritária, por exemplo, um ciclo vigoroso de investimentos em infra-estrutura e criação de nova capacidade produtiva, onde, com certeza 
a ampliação da capacidade instalada em geração de energia deve ser vista como um dos pilares desta opção.

Nesse cenário, seria oportuno ampliar à discussão sobre o papel das fontes alternativas de energia, em especial os biocombustíveis, onde o Brasil poderia se transformar em um grande exportador não apenas de seu produto, mas também, de capacidade tecnológica, abrindo espaço para a revisão da estratégia, por exemplo, de outras cadeias de exportações, tais como a de setores eletrointensivos.

Enquanto esse novo rumo não é dado, as empresas eletrointensivas estão se adequando às mudanças em curso, em especial dadas às alterações conduzidas no âmbito do setor elétrico brasileiro, o que será retratado a seguir.

\subsection{A PITCE e o setor elétrico brasileiro: uma resposta do setor eletrointensivo}

A partir desse conjunto de informações, detalhado ao longo das páginas anteriores, que evidencia, de um lado, o novíssimo modelo de organização do setor elétrico brasileiro, com destaque para a coexistência de dois ambientes de contratação de energia elétrica, ou seja, o ambiente de contratação regulada (ACR) e o ambiente de contratação livre (ACL), e, de outro, a tendência à expansão dos setores eletrointensivos na pauta de exportação brasileira, a seguir será mapeado qual tem sido o comportamento das indústrias vinculadas a esse segmento, neste cenário.

Considerando que são empresas com alto consumo de energia em seus processos produtivos, representando $45 \%$ do total de energia elétrica industrial consumida no país, com a estimativa de crescimento médio anual deste consumo em torno de $4 \%$, para os próximos cinco anos, ver Tabela 4.1., é de se esperar que as empresas ou passem a assegurar o suprimento de energia elétrica através de algum tipo de geração deste insumo para consumo próprio e/ou busquem melhores preços, através de sua participação na compra de energia no ambiente de contratação livre. Avaliar as opções utilizadas por tais agentes será a preocupação central deste último tópico da presente tese de doutorado.

Tabela 4.1.

Previsão de consumo de energia elétrica (MWh) 


\begin{tabular}{|l||r||r||r||}
\multicolumn{1}{|c|}{ dos setores industriais eletrointensivos } \\
\hline \multicolumn{1}{|c|}{ Setor } & $\mathbf{2 0 0 1}$ & $\mathbf{2 0 0 5}$ & $\mathbf{2 0 1 0}$ \\
\hline \hline Alumínio & 21.301 & 24.970 & 27.000 \\
\hline \hline Siderurgia & 16.259 & 19.090 & 21.800 \\
\hline \hline Ferroligas & 6.801 & 8.180 & 9.160 \\
\hline \hline Papel & 7.457 & 8.830 & 11.000 \\
\hline \hline Celulose & 7.812 & 9.640 & 15.000 \\
\hline \hline Petroquímica & 4.201 & 5.160 & 6.850 \\
\hline \hline
\end{tabular}

Fonte: Bermann (2006)

\subsubsection{O setor eletrointensivo e a opção pela autoprodução de energia elétrica}

Conforme explicitado no capítulo anterior, o Decreto 1.009/93, em seu artigo $3^{\circ}$, parágrafo único, define autoprodutor como sendo a pessoa jurídica pública ou privada, que esteja capacitada a produzir individualmente, ou de forma consorciada, energia elétrica para uso próprio, fornecendo o excedente ao concessionário de serviço público. Na seqüência, com o processo de reorganização do setor elétrico brasileiro, formalizado através da Lei 9.074/95, foi instituída a figura do produtor independente de energia elétrica, posteriormente regulamentada pelo Decreto 2.003/96, com modificações adicionais tendo sido introduzidas pela Lei 9.427/96 e Lei 9.648/98, que estabeleceram as condições para outorga de concessão ou autorização para o produtor independente.

$\mathrm{Na}$ verdade, esse grupo de medidas visou flexibilizar o conceito de autoprodutor, que, conforme lembra o Relatório Analítico da Empresa de Pesquisa Energética - EPE (2005), tradicionalmente era entendido como:

"o consumidor que dispunha de instalações próprias de geração de energia elétrica, localizadas próximo às suas unidades de consumo, não utilizando para esse auto-suprimento a rede elétrica de concessionários de distribuição/transmissão".

Neste caso, não seriam demandados recursos públicos adicionais para a efetivação de tais projetos, pois a maioria de tais empreendimentos era em cogeração, nem utilizada a rede elétrica de concessionários de distribuição/transmissão.

Com a instituição da figura do produtor independente de energia, entretanto, esse conceito foi ampliado, permitindo outros arranjos comerciais, com a possibilidade, 
inclusive, de associação entre consumidores interessados no auto-suprimento e concessionárias de serviço público de geração. De maneira a diferenciar esse tipo de autoprodução com a do conceito clássico anteriormente definido, esse novo agente passou a ser denominado, conforme lembra a EPE (2005), de autoprodutor transportado, "numa alusão ao fato de que esse tipo de autoprodutor faz uso de instalações de transporte (transmissão e/ou distribuição)".

Assim, a energia associada a tais empreendimentos passa a ser computada tanto do lado da oferta do sistema, como do lado da demanda, uma vez que, ao ser admitida "a figura da geração própria distante da instalação de consumo" ${ }^{128}$, a parcela de energia elétrica própria a ser consumida por este novo empreendimento será retirada da rede de transmissão, subtransmissão e, muitas vezes, da própria rede de distribuição, alterando-se o conceito clássico de autoprodutor, até então utilizado.

A partir dessa flexibilização, o governo federal sinalizou, no âmbito da reestruturação conduzida a partir de 1995, sua forte intenção de encontrar no parceiro privado um aliado na tarefa de ampliar a capacidade instalada de energia elétrica no país, abrindo a possibilidade de sociedades em empreendimentos de geração hidrelétrica, em especial, com empresas vinculadas aos setores industriais eletrointensivos.

Ademais, cumpre destacar que durante esta fase do processo de reestruturação brasileiro, as licitações eram julgadas pelo critério de maior oferta de pagamento pelo uso do bem público, o que permitiu excessivos ágios no momento da concorrência, mesmo sob o risco de que o projeto de engenharia e/ou a licença ambiental não fossem concedidos, situação que foi alterada com a publicação da Lei 10.848/2004, que dispôs sobre a comercialização de energia no País.

Dessa forma, quando se avaliam as 55 usinas hidrelétricas licitadas diretamente pela ANEEL, entre os anos de 1995 a 2002, são identificados 15 projetos em que pelos menos um de seus empreendedores vincula-se ao setor eletrointensivos, possibilitando uma ampliação da capacidade instalada da ordem de $4.836 \mathrm{MW}$, conforme dados se expressos no Quadro 4.2. Deste total, apenas seis já se encontram em operação, representando 782 MW, ou seja, $16 \%$ do total previsto.

\footnotetext{
${ }^{128} \operatorname{EPE} / \mathrm{MME}(2005$, p. 72).
} 
Quadro 4.2.

Usinas hidrelétricas licitadas pela ANEEL para autoprodução (AP)/Produção Independente (PI) de propriedade de setores industriais eletrointensivos: 1995 - 2002

\begin{tabular}{|c|c|c|c|c|c|c|}
\hline Empreendimento & Localização & $\begin{array}{c}\text { Capac. } \\
\text { instalada } \\
\text { MW }\end{array}$ & Empreendedores & $\begin{array}{l}\text { Destino da } \\
\text { Energia }\end{array}$ & $\begin{array}{c}\text { Data da } \\
\text { Licitação }\end{array}$ & $\begin{array}{c}\text { Situação atual } \\
\text { (previsão de } \\
\text { entrada em } \\
\text { operação) }\end{array}$ \\
\hline \multicolumn{7}{|l|}{ Concorrência 1997} \\
\hline UHE Porto Estrela & $\begin{array}{l}\text { Rio Santo } \\
\text { Antônio MG }\end{array}$ & 112 & $\begin{array}{l}\text { CEMIG, CVRD, } \\
\text { Coteminas e NES }\end{array}$ & $\begin{array}{l}\mathrm{PI}(20 \%) / \\
\operatorname{AP}(80 \%)\end{array}$ & $10 / 7 / 1997$ & $\begin{array}{l}\text { em operação } \\
\text { desde } 2001\end{array}$ \\
\hline \multicolumn{7}{|l|}{ Concorrência 1998} \\
\hline UHE Piraju & $\begin{array}{c}\text { Rio } \\
\text { Paranapanema } \\
\text { SP }\end{array}$ & 80 & $\begin{array}{l}\text { Companhia Brasileira } \\
\text { de Alumínio }\end{array}$ & $\mathrm{AP}$ & 1998 & $\begin{array}{l}\text { em operação } \\
\text { desde } 2002\end{array}$ \\
\hline \multicolumn{7}{|l|}{ Concorrência 2000} \\
\hline $\begin{array}{l}\text { UHE Risoleta } \\
\text { Neves } \\
\text { (ex-Candonga) }\end{array}$ & Rio Doce MG & 140 & $\begin{array}{c}\text { Companhia Vale do } \\
\text { Rio Doce }(50 \%) \text { e } \\
\text { Alcan } \\
\text { Emepreendimentos } \\
(50 \%)\end{array}$ & PI/AP & $28 / 1 / 2000$ & $\begin{array}{l}\text { em operação } \\
2003-2004\end{array}$ \\
\hline UHE Picada & Rio Peixe $\quad$ MG & 50 & $\begin{array}{c}\text { Companhia Paraibuna } \\
\text { de Metais }(99 \%) \text { e } \\
\text { Paraibuna Energia } \\
(1 \%) \\
\end{array}$ & $\begin{array}{l}\text { PI }(1 \%) / \\
\text { AP }(99 \%)\end{array}$ & $30 / 11 / 2000$ & $\begin{array}{l}\text { em operação } \\
2006\end{array}$ \\
\hline $\begin{array}{l}\text { UHE Capim Branco } \\
\text { I }\end{array}$ & $\begin{array}{c}\text { Rio Araguaia } \\
\text { MG }\end{array}$ & 240 & $\begin{array}{c}\text { CEMIG Capim } \\
\text { Branco Energia } \\
(21,05 \%), \text { CVRD } \\
(48,421 \%), \text { Com. e } \\
\text { Agrícola Paineiras } \\
(17,89 \%), \text { Votorantim } \\
\text { Metais Zinco S/A } \\
(12,63 \%)\end{array}$ & $\begin{array}{l}\operatorname{PI}(37 \%) / \\
\operatorname{AP}(63 \%)\end{array}$ & $30 / 11 / 2000$ & $\begin{array}{l}\text { em operação } \\
2006\end{array}$ \\
\hline $\begin{array}{l}\text { UHE Capim Branco } \\
\text { II }\end{array}$ & $\begin{array}{c}\text { Rio Araguaia } \\
\text { MG }\end{array}$ & 210 & $\begin{array}{c}\text { CEMIG Capim } \\
\text { Branco Energia } \\
(20 \%), \text { CVRD }(46 \%), \\
\text { Com. e Agrícola } \\
\text { Paineiras }(17 \%), \\
\text { Comp. Mineira de } \\
\text { Metais }(12 \%) \text { e } \\
\text { Camargo Correa }(5 \%)\end{array}$ & $\begin{array}{l}\text { PI }(37 \%) / \\
\operatorname{AP}(63 \%)\end{array}$ & $30 / 11 / 2000$ & $\begin{array}{l}\text { Com obras já } \\
\text { iniciadas e sem } \\
\text { problemas } \\
(2006-2007)\end{array}$ \\
\hline \multicolumn{7}{|l|}{$\begin{array}{c}\text { Concorrência } \\
1^{\circ} \text { sem./2001 }\end{array}$} \\
\hline $\begin{array}{l}\text { UHE Foz do } \\
\text { Chapecó }\end{array}$ & $\begin{array}{c}\text { Rio Araguaia } \\
\text { RS/SC }\end{array}$ & 828,20 & $\begin{array}{c}\text { CVRD }(40 \%) \text { e Foz } \\
\text { do Chapecó Energia } \\
(60 \%)\end{array}$ & PI/AP & $28 / 6 / 2001$ & $\begin{array}{c}\text { Existem } \\
\text { impedimentos } \\
\text { para a entrada em } \\
\text { operação (2010- } \\
\text { 2011) } \\
\end{array}$ \\
\hline
\end{tabular}




\begin{tabular}{|c|c|c|c|c|c|c|}
\hline UHE Serra do Facão & $\begin{array}{c}\text { Rio São Marcos } \\
\text { GO }\end{array}$ & 212,60 & $\begin{array}{c}\text { Alcoa Alumínio } \\
(50,4 \%) \text {, CBA }(17 \%), \\
\text { DME Energética } \\
(10,1 \%) \text { e Votorantin } \\
\text { Cimentos }(22,5 \%)\end{array}$ & $\begin{array}{c}\text { PI } \\
(83.03 \%) / \\
\text { AP } \\
(16,97 \%)\end{array}$ & $28 / 6 / 2001$ & $\begin{array}{c}\text { Obras iniciadas, } \\
\text { mas com graves } \\
\text { problemas para a } \\
\text { entrada em } \\
\text { operação } \\
\text { (2009) }\end{array}$ \\
\hline \multicolumn{7}{|l|}{$\begin{array}{c}\text { Concorrência } \\
2^{\circ} \mathrm{sem} . / 2001\end{array}$} \\
\hline UHE Salto Pilão & Rio Itajaí $\quad \mathrm{SC}$ & 182,30 & $\begin{array}{c}\text { CPFL, Alcoa } \\
\text { Alumínio, Camargo } \\
\text { Correa, DME } \\
\text { Energética e } \\
\text { Votorantin Cimentos }\end{array}$ & PI/AP & $30 / 11 / 2001$ & $\begin{array}{c}\text { Existem } \\
\text { impedimentos } \\
\text { para a entrada em } \\
\text { operação (2008) }\end{array}$ \\
\hline $\begin{array}{l}\text { UHE Pedra do } \\
\text { Cavalo }\end{array}$ & $\begin{array}{c}\text { Rio Paraguaçu } \\
\text { BA }\end{array}$ & 160 & Votorantin Cimentos & PI/AP & $30 / 11 / 2001$ & $\begin{array}{c}\text { Em operação } \\
2004-2005\end{array}$ \\
\hline UHE Pai Querê & $\begin{array}{l}\text { Rio Pelotas } \\
\text { SC/RS }\end{array}$ & 292 & $\begin{array}{c}\text { CPFL, Alcoa } \\
\text { Alumínio, CEEE, } \\
\text { DME Energética e } \\
\text { Votorantin Cimentos }\end{array}$ & PI/AP & $30 / 11 / 2001$ & $\begin{array}{c}\text { Graves } \\
\text { problemas para a } \\
\text { entrada em } \\
\text { operação } \\
(2009)\end{array}$ \\
\hline UHE Santa Isabel & $\begin{array}{c}\text { Rio Araguaia } \\
\text { TO/PA }\end{array}$ & 1.087 & $\begin{array}{l}\text { Billiton Metais, } \\
\text { CVRD, Camargo } \\
\text { Correa; Alcoa }\end{array}$ & AP & $30 / 11 / 2001$ & $\begin{array}{c}\text { Graves } \\
\text { problemas para a } \\
\text { entrada em } \\
\text { operação } \\
(2009-2010) \\
\end{array}$ \\
\hline \multicolumn{7}{|l|}{ Concorrência 2002} \\
\hline $\begin{array}{l}\text { UHE Barra dos } \\
\text { Coqueiros }\end{array}$ & $\begin{array}{c}\text { Rio Claro } \\
\text { GO }\end{array}$ & 90 & Alcan Alumínio & $\mathrm{AP}$ & $12 / 7 / 2002$ & $\begin{array}{c}\text { Graves } \\
\text { problemas para a } \\
\text { entrada em } \\
\text { operação } \\
\text { (2008) }\end{array}$ \\
\hline UHE Caçu & $\begin{array}{l}\text { Rio Claro } \\
\text { GO }\end{array}$ & 65 & Alcan Alumínio & AP & $12 / 7 / 2002$ & $\begin{array}{c}\text { Graves } \\
\text { problemas para a } \\
\text { entrada em } \\
\text { operação } \\
(2008) \\
\end{array}$ \\
\hline UHE Estreito & $\begin{array}{c}\text { Rio Tocantis } \\
\text { TO/MA }\end{array}$ & 1.087 & $\begin{array}{c}\text { Alcoa Alumínio, } \\
\text { CVRD, Camargo } \\
\text { Correa, BHH Billiton, } \\
\text { Tractebel }\end{array}$ & PI/AP & $12 / 7 / 2002$ & $\begin{array}{c}\text { Graves } \\
\text { problemas para a } \\
\text { entrada em } \\
\text { operação } \\
(2008-2010) \\
\end{array}$ \\
\hline $\begin{array}{c}\text { TOTAL } \\
\text { (Concorrências } \\
\text { ANEEL) }\end{array}$ & $\begin{array}{l}15 \text { usinas } \\
\text { licitadas }\end{array}$ & 4.836 & & & & \\
\hline
\end{tabular}

Fonte: Aneel (julho, 2006). Elaboração própria

O Quadro 4.3, por sua vez, discrimina outros 17 projetos licitados, com a anuência da ANEEL. Ressalte-se, entretanto, que ao contrário dos empreendimentos anteriormente listados, desse conjunto 10 já estão em operação, viabilizando um aumento na capacidade 
instalada da ordem de $2.985 \mathrm{MW}$, algo em torno de $70 \%$ do total previsto.

Quadro 4.3.

Outras usinas hidrelétricas licitadas para autoprodução (AP)/Produção Independente (PI) de propriedade de setores industriais eletrointensivos, com anuência da ANEEL

$1995-2002$

\begin{tabular}{|c|c|c|c|c|c|c|}
\hline Empreendimento & Localização & $\begin{array}{l}\text { Capac. } \\
\text { instalada } \\
\text { MW }\end{array}$ & Empreendedores & $\begin{array}{l}\text { Destino da } \\
\text { Energia }\end{array}$ & $\begin{array}{c}\text { Data da } \\
\text { Licitação }\end{array}$ & $\begin{array}{c}\text { Situação atual } \\
\text { (previsão de } \\
\text { entrada em } \\
\text { operação) } \\
\end{array}$ \\
\hline UHE Barra Grande & $\begin{array}{l}\text { Rio Pelotas } \\
\text { SC/RS }\end{array}$ & 698,25 & $\begin{array}{c}\text { CPFL Geração de } \\
\text { Energia (25,0059\%), } \\
\text { Alcoa Alumínio } \\
(42,1752 \%), \\
\text { Companhia Brasileira } \\
\text { de Alumínio (15\%); } \\
\text { DM Energética } \\
(8,8189 \%) \text { e Camargo } \\
\text { Correa Cimentos } \\
(9 \%)\end{array}$ & PI & $12 / 4 / 2000$ & $\begin{array}{l}\text { em operação } \\
2005-2006\end{array}$ \\
\hline UHE Baú I & $\begin{array}{l}\text { Rio Piranga } \\
\text { MG }\end{array}$ & 110 & Samarco Mineração & $\mathrm{AP}$ & $30 / 11 / 1995$ & $\begin{array}{c}\text { Graves } \\
\text { problemas para a } \\
\text { entrada em } \\
\text { operação } \\
(2010) \\
\end{array}$ \\
\hline UHE Irapé & $\begin{array}{c}\text { Rio } \\
\text { Jequitinhonha } \\
\text { MG }\end{array}$ & 360 & $\begin{array}{c}\text { Camargo Correa, } \\
\text { Alcoa, CVRD, Cemig }\end{array}$ & $\mathrm{PI} / \mathrm{AP}$ & 1998 & $\begin{array}{c}\text { Com obras já } \\
\text { iniciadas e sem } \\
\text { problemas (2006) }\end{array}$ \\
\hline UHE Canoas I e II & $\begin{array}{c}\text { Rio } \\
\text { Paranapanema } \\
\text { SP }\end{array}$ & 153 & $\begin{array}{c}\text { CBA }(50,3 \%) \text { e CESP } \\
(49,7 \%)\end{array}$ & $\mathrm{PI} / \mathrm{AP}$ & $30 / 7 / 1998$ & $\begin{array}{l}\text { em operação } \\
\text { desde } 1999\end{array}$ \\
\hline UHE Ita & $\begin{array}{l}\text { Rio Uruguaia } \\
\text { SC/RS }\end{array}$ & 290 & $\begin{array}{c}\text { CSN, Cia Cimento } \\
\text { Itambé, Poliolefinas, } \\
\text { Cia. Industrial } \\
\text { Propileno }\end{array}$ & $\mathrm{PI} / \mathrm{AP}$ & $21 / 12 / 1995$ & $\begin{array}{l}\text { em operação } \\
\text { desde } 2001\end{array}$ \\
\hline $\begin{array}{l}\text { UHE Guilman } \\
\text { Amorin }\end{array}$ & $\begin{array}{c}\text { Rio Piracicaba } \\
\text { MG }\end{array}$ & 140 & $\begin{array}{c}\text { Cia. Siderúrugica } \\
\text { Belgo-Mineira (51\%), } \\
\text { Samarco Mineração } \\
(49 \%)\end{array}$ & AP & 19/5/1998 & $\begin{array}{l}\text { em operação } \\
\text { desde } 1998\end{array}$ \\
\hline $\begin{array}{l}\text { UHE Dona } \\
\text { Francisca }\end{array}$ & $\begin{array}{c}\text { Rio Jacuí } \\
\text { RS }\end{array}$ & 125 & $\begin{array}{c}\text { Alcoa (19,7\%), } \\
\text { Camargo Correa } \\
(15,7 \%), \text { Cia. } \\
\text { Cimento Votorantin } \\
(13,1 \%), \text { Grupo } \\
\text { Gerdau }(13 \%), \text { Celesc } \\
(15 \%) \text { e Inepar }(25 \%)\end{array}$ & $\mathrm{PI} / \mathrm{AP}$ & $18 / 8 / 1997$ & $\begin{array}{l}\text { em operação } \\
\text { desde } 2001\end{array}$ \\
\hline
\end{tabular}




\begin{tabular}{|c|c|c|c|c|c|c|}
\hline UHE Machadinho & $\begin{array}{l}\text { Rio Pelotas } \\
\text { SC/RS }\end{array}$ & 1.140 & $\begin{array}{c}\text { Alcoa }(19,7 \%), \\
\text { Eletrosul }(17 \%), \\
\text { Celesc }(12,1 \%), \\
\text { Camargo Correa } \\
(4,6 \%), \text { CBA }(9,3 \%), \\
\text { Ind. Votorantin } \\
(7,9 \%), \text { Portland Rio } \\
\text { Branco }(7,9 \%), \\
\text { Valesul }(7,3 \%), \\
\text { Inepar, Copel }(4,3 \%) \\
\text { e CEEE }(4,9 \%)\end{array}$ & PI/AP & $15 / 1 / 1997$ & $\begin{array}{l}\text { em operação } \\
\text { desde } 2002\end{array}$ \\
\hline UHE Igarapava & $\begin{array}{c}\text { Rio Parnaiba } \\
\text { MG }\end{array}$ & 210 & $\begin{array}{c}\text { CEMIG (14,5\%), Cia. } \\
\text { Mineira de Metais } \\
(23,9346 \%), \text { CSN } \\
(17,9204 \%), \text { CVRD } \\
(38,1450 \%), \\
\text { Anglogold/Mineração } \\
\text { Morro Velho }(5,5 \%)\end{array}$ & PI/AP & 28/9/1995 & $\begin{array}{c}\text { em operação } \\
\text { desde } 1999\end{array}$ \\
\hline UHE Sobragi & $\begin{array}{c}\text { Rio Paraibuna } \\
\text { MG }\end{array}$ & 38 & $\begin{array}{c}\text { 100\% Siderúrgica } \\
\text { Barra Mansa }\end{array}$ & AP & $13 / 11 / 1996$ & $\begin{array}{c}\text { em operação } \\
\text { desde } 1998\end{array}$ \\
\hline UHE Funil & $\begin{array}{l}\text { Rio Grande } \\
\text { MG }\end{array}$ & 180 & $\begin{array}{l}\text { CEMIG, Andrade } \\
\text { Gutieerez, Samarco, } \\
\text { Ferro Ligas Domyni }\end{array}$ & $\mathrm{AP}$ & 2/8/1996 & $\begin{array}{c}\text { em operação } \\
\text { desde } 2002 / 2003\end{array}$ \\
\hline UHE Melo & Rio Preto $\quad \mathrm{MG}$ & 10,865 & Valesul Alumínio & AP & $7 / 12 / 1995$ & $\begin{array}{c}\text { em operação } \\
\text { desde } 1998\end{array}$ \\
\hline UHE Traíra II & $\begin{array}{l}\text { Rio Suaçuí } \\
\text { Grande } \quad \text { MG }\end{array}$ & 60 & Alcan Alumínio & $\mathrm{AP}$ & $12 / 7 / 2002$ & n.d. \\
\hline UHE Campinho & Rio Jucu ES & 181 & $\begin{array}{c}\text { Companhia Paraibuna } \\
\text { de Metais }\end{array}$ & AP & - & n.d. \\
\hline $\begin{array}{l}\text { UHE Serra } \\
\text { Quebrada }\end{array}$ & $\begin{array}{c}\text { Rio Tocantis } \\
\text { TO/MA }\end{array}$ & 210 & $\begin{array}{c}\text { Alcoa Alumínio, } \\
\text { Billiton Metais, } \\
\text { Eletronorte, } \\
\text { Eletrobrás, Camargo } \\
\text { Correa Energia e } \\
\text { CVRD }\end{array}$ & PI/AP & - & n.d. \\
\hline UHE Ponte Nova & $\begin{array}{l}\text { Rio Ipiranga } \\
\text { MG }\end{array}$ & 170 & $\begin{array}{c}\text { Grupo Fiat e Alcan } \\
\text { Alumínio }\end{array}$ & AP & $30 / 11 / 1995$ & n.d. \\
\hline UHE Pilar & $\begin{array}{l}\text { Rio Piranga } \\
\text { MG }\end{array}$ & 170 & Grupo Fiat & $\mathrm{AP}$ & $30 / 11 / 1995$ & n.d. \\
\hline $\begin{array}{c}\text { TOTAL } \\
\text { (anuência ANEEL) }\end{array}$ & $\begin{array}{l}17 \text { usinas } \\
\text { licitadas }\end{array}$ & 4.246 & & & & \\
\hline
\end{tabular}

Não foram encontrados registros sobre seus atuais estágios.

Fonte: Aneel (julho, 2006). Elaboração própria

Por outro lado, quando se avaliam as 37 usinas sob fiscalização da ANEEL, em que parte das anteriores encontram-se incluídas, verificam-se que apenas 12 empreendimentos 
encontram-se com as obras iniciadas sem nenhum tipo de problema, as demais ainda registram diversos tipos de constrangimentos para entrarem em operação, envolvendo desde suspensão do processo de licenciamento ambiental, solicitação de concessão, demandas judiciais, até mesmo com o seu cronograma de implantação suspenso, conforme Quadro 4.4..

Quadro 4.4.

Situação das usinas fiscalizadas pela ANEEL - julho/2006

\begin{tabular}{|c|c|c|c|}
\hline $\begin{array}{c}\text { Situação das usinas } \\
\text { fiscalizadas }\end{array}$ & $\begin{array}{c}\text { Número } \\
\text { de usinas } \\
\text { na } \\
\text { situação }\end{array}$ & $\begin{array}{l}\text { Percentagem } \\
\text { sobre o total } \\
\text { fiscalizado } \\
\text { (em \%) }\end{array}$ & $\begin{array}{c}\text { Capacidade } \\
\text { Instalada prevista } \\
\text { (em MW) }\end{array}$ \\
\hline $\begin{array}{l}\text { Com obras já iniciadas e sem } \\
\text { problemas }\end{array}$ & 12 & 32,4 & $3.417,54$ \\
\hline $\begin{array}{l}\text { Com obras já iniciadas, mas com } \\
\text { problemas }\end{array}$ & 2 & 5,4 & 379,60 \\
\hline $\begin{array}{l}\text { Existem impedimentos para } \\
\text { entrada em operação (obras não } \\
\text { iniciadas, atraso na obtenção de } \\
\text { licença, comprometimento na } \\
\text { implantação) }\end{array}$ & 7 & 18,9 & $1.585,50$ \\
\hline $\begin{array}{l}\text { Graves problemas para a entrada } \\
\text { em operação (suspensão do } \\
\text { processo de licenciamento } \\
\text { ambiental, solicitação de rescisão } \\
\text { amigável do contrato de concessão, } \\
\text { demandas judiciais, declaração de } \\
\text { inviabilidade ambiental do } \\
\text { empreendimento) }\end{array}$ & 14 & 37,9 & $3.475,60$ \\
\hline $\begin{array}{l}\text { Cronograma de implantação } \\
\text { suspenso }\end{array}$ & 2 & 5,4 & 95,00 \\
\hline TOTAL & 37 & 100 & $8.953,24(*)$ \\
\hline
\end{tabular}

(*) Refere-se ao total previsto até 2011. Elaboração própria. Fonte: ANEEL (relatório julho/2006)

Ressalte-se, ainda, que das 25 usinas hidrelétricas com problemas, 9 envolvem pelo menos um dos parceiros relacionados a empresas eletrointensivas, conforme foi sinalizado nos Quadros 4.2 e 4.3, ressaltando que: a) a UHE Serra do Facão está com as obras iniciadas, mas com graves problemas para a entrada em operação; b) a UHE Foz do Chapecó e a UHE Salto Pilão registram impedimentos para a entrada em operação; e c) seis outras UHE estão com graves problemas para a entrada em operação. Ressalte-se, também, que oito desses empreendimentos foram licitados entre 2001 e 2002, em meio à crise de 
energia, sendo que apenas a UHE de Baú I foi licitada em final de 1995.

A partir de tais informações, pode-se concluir que, considerando-se apenas as usinas que se encontram com graves problemas para entrada em operação e na hipótese de os mesmos não serem corrigidos, levando à declaração de inviabilidade ambiental do empreendimento, a capacidade instalada poderá ser comprometida em até $42 \%$ do total previsto para ser realizado em 2011, afetando, assim, as expectativas do governo federal quanto à ampliação futura do parque de geração elétrica nacional.

Por este motivo é que, a partir de 2004, dentre as mudanças introduzidas através da Lei 10.848, que dispôs sobre a comercialização de energia, as usinas somente são licitadas com os estudos de engenharia já aprovados, licença ambiental prévia e reserva de disponibilidade hídrica, e nos termos do plano de outorgas, definido pelo Ministério de Minas e Energia.

Por outro lado, os dados divulgados, para os anos de 2003 e 2004, no Balanço Energético Nacional, explicitados na Tabela 4.2, demonstram que a capacidade instalada de geração elétrica de autoprodutores clássicos, para os setores selecionados, incluindo base hidro e termo, manteve-se a mesma, totalizando $2.724,5 \mathrm{MW}$, representando quase $53 \%$ do total da capacidade de geração elétrica instalada por esses agentes no Brasil

Tabela 4.2.

Capacidade instalada de geração elétrica de autoprodutores em MW, em $31 / 12 / 2004{ }^{(*)}$

\begin{tabular}{|l|r|c|r|r|r|r|}
\hline \multicolumn{1}{|c|}{ Região } & Siderurgia & $\begin{array}{c}\text { Ferro- } \\
\text { ligas }\end{array}$ & Mineração & Alumínio & \multicolumn{1}{c|}{$\begin{array}{c}\text { Papel e } \\
\text { Celulose }\end{array}$} & $\begin{array}{c}\text { Outros } \\
\text { Setores }\end{array}{ }^{* * *}$ \\
\hline Norte & 4,00 & - & 91,30 & - & 55,00 & 8,00 \\
\hline Nordeste & 26,00 & - & 6,50 & 10,00 & 114,40 & 399,20 \\
\hline Sudeste & 902,30 & 14,80 & 43,40 & 510,50 & 685,00 & $1.670,80$ \\
\hline Sul & - & - & - & - & 258,50 & 199,40 \\
\hline $\begin{array}{l}\text { Centro } \\
\text { Oeste }\end{array}$ & - & - & 2,80 & - & & 178,60 \\
\hline TOTAL & $\mathbf{9 3 2 , 3 0}$ & $\mathbf{1 4 , 8 0}$ & $\mathbf{1 4 4 , 0 0}$ & $\mathbf{5 2 0 , 5 0}$ & $\mathbf{1 . 1 1 2 , 9 0}$ & $\mathbf{2 . 4 5 6 , 0 0}$ \\
\hline
\end{tabular}

${ }^{(*)}$ Os valores semelhantes aos de 31/12/2003. ${ }^{(* *)}$ Em outros setores foram agrupados: cimento, nãoferrosos, química, alimentos e bebidas, açúcar e álcool, têxtil, cerâmica e outros. Fonte: Balanço Energético Nacional - BEN, 2005.

Os dados evidenciam, ainda, a concentração desta geração na região sudeste para o conjunto dos segmentos, à exceção do setor de mineração, cuja capacidade instalada 
encontra-se na região norte, respondendo por $63,4 \%$ do total gerado por essas empresas.

Com base nos dados anteriormente demonstrados, pode-se concluir que, em especial, durante os anos de 2001/2002, houve uma forte tendência das empresas vinculadas ao setor eletrointensivo centrarem parte de seus investimentos em empreendimentos de pequenas centrais hidrelétricas, visando tanto minimizar sua dependência energética da capacidade de geração instalada no país, fugindo de eventuais períodos de racionamento, como reduzir custos com a produção de parte de sua energia consumida.

Ocorre, entretanto, que segundo informações colhidas junto à CCEE, com a normatização da ANEEL sob o uso da rede de transmissão pelos consumidores livres, bem como autoprodutores, no caso em que a planta de geração não estiver localizada no mesmo local da planta industrial e torne necessária a utilização da rede da concessionária, é dever e obrigação do proprietário, autoprodutor transportado, tomar as seguintes providências:

a) Participar da CCEE como agente de operação, desde que sua instalação tenha potência instalada $\geq 50 \mathrm{MW}$ e despachada pelo ONS.

b) Participar como agente de comercialização;

c) Registrar mensalmente a energia gerada e consumida para fins de liquidação contábil dessa energia;

d) Como agente da CCEE participar no processo de rateio de custeio da Câmara;

e) Formalizar junto a concessionária local a utilização do sistema elétrico sob responsabilidade da mesma, celebrando contrato de conexão e uso do sistema, podendo ser de distribuição ou transmissão, dependendo de como será efetuado o acesso à rede;

f) Para a celebração de tais contratos é necessário definir os valores de demanda de ponta e fora de ponta.

Ademais, a partir de 2005, conforme normatização da ANEEL, os consumidores livres e autoprodutores de energia, conectados à Rede Básica do Sistema Interligado Nacional (SIN), terão que recolher valores correspondentes à Conta de Consumo de Combustíveis - CCC, e à Conta de Desenvolvimento Energético - CDE, na tarifa paga às 
concessionárias de transmissão ${ }^{129}$. Tais encargos passarão a compor a Tarifa de Uso do Sistema de Transmissão (TUST) paga por esses usuários, com a isenção da TUSD - Tarifas de Uso pelo Serviço de Distribuição, para o gerador e consumidor, cujas plantas de geração entraram em operação até dezembro de $2003^{130}$.

Dessa forma, pode-se concluir que as exigências e os encargos adicionais estabelecidos para o autoprodutor transportado, em associação com os riscos ambientais relacionados a investimentos desse tipo, podem estar afastando as empresas eletrointensivas de empreendimentos em autoprodução. Em 2005, por exemplo, das sete usinas que foram licitadas pela ANEEL, com o propósito de incrementar cerca de 804,6 MW na potência instalada, em nenhum destes projetos verifica-se a presença de empresas vinculadas ao setor eletrointensivos.

Assim, fica caracterizado que tais empreendimentos, embora amplamente estimulados ao longo da gestão anterior, podem estar sendo substituídos por contratos bilaterais, no Ambiente de Contratação Livre (ACL), conforme será avaliado no processo item do presente capítulo.

\subsubsection{O setor eletrointensivo e o Ambiente de Contratação Livre (ACL)}

Como visto no item anterior, durante os anos de 1997 a 2002, foi estimulada a opção de empreendimentos configurados como regime de autoprodução e/ou produção independente de energia elétrica entre as empresas eletrointensivas, que, em parte, em decorrência da falta de obrigatoriedade prévia das devidas autorizações ambientais e/ou de seus projetos executivos, resultaram em suas paralisações, no aguardo da superação de tais constrangimentos.

Em paralelo, e dada à introdução do "novíssimo" modelo de reestruturação do setor elétrico brasileiro, parece que as empresas eletrointensivas vêm buscando outras saídas para ter assegurado o fornecimento de energia no longo prazo, com qualidade e preços competitivos, abandonando provisoriamente a opção de empreendimentos na área de geração. Dentre as opções que se colocam destacam-se: a) participação em leilões de excedentes de energia elétrica; e b) leilão de compra de energia para uso próprio, no âmbito

\footnotetext{
${ }^{129}$ Conforme dispostos na Resolução Normativa no 74/04, da ANEEL.

${ }^{130}$ Conforme disposto na Resolução Normativa n ${ }^{\circ}$ 157/o5, da ANEEL.
} 
do Ambiente de Contratação Livre (ACL).

\subsubsection{Participação no leilão de excedente de energia elétrica}

Conforme foi estabelecido pela Lei $\mathrm{n}^{0}$ 9.648/98, a partir de janeiro de 2003, as empresas de energia elétrica tiveram seus contratos de suprimento reduzidos em $25 \%$ ao ano, acarretando em uma sobra de energia estimada em torno de 7,5 mil MW médios.

Desta forma, em maio de 2003, o Ministério das Minas e Energia ${ }^{131}$, motivado por esta descontratação e a partir de um acordo firmado com a Associação Brasileira dos Grandes Consumidores Industriais de Energia (ABRACE) e a Associação Brasileira das Empresas Geradoras de Energia (ABRAGE), definiu as diretrizes para a realização de leilões destes excedentes de energia elétrica existentes no país ${ }^{132}$, a serem efetuados, exclusivamente, entre as concessionárias e autorizadas de geração e os consumidores finais, ou seja, aqueles com carga igual ou superior a $3.000 \mathrm{~kW}$.

Assim, passado o período de 15 dias, onde a ANEEL realizou Audiências Públicas a fim de aperfeiçoar os procedimentos previstos para o leilão, a agência, em julho de 2003, regulamentou a operação, definindo, dentre outros pontos, que: a) somente poderiam participar dos leilões, os consumidores livres que não necessitassem expandir os sistemas de transmissão e distribuição existentes no recebimento de tal incremento; b) deveria ser criado um Encargo de Serviços de Distribuição (ESD) a ser pago pelos compradores de leilões, para a cobertura dos custos legais e setoriais do fornecimento; e c) os contratos seriam válidos por um prazo de dois anos, contados a partir do efetivo cumprimento da prestação obrigacional.

Com isso, em 12 de setembro de 2003, foi efetivado o referido leilão de excedente de energia, que tendo sido ofertado 5.753,7 MW médio acabou negociando apenas 912,2 MW médio, representado cerca de $16 \%$ do total. Do volume negociado, 90,2\% foram adquiridos por grupos vinculados a setores eletrointensivos, assim distribuídos: 40,1\% para empresas siderúrgicas, 30,7\% para de alumínio, 13,5\% para ferro-ligas e 5,9\% para papel e

\footnotetext{
${ }^{131}$ Tal medida foi definida através da Resolução no ${ }^{\circ}$ 3, de 22/05/2003, do Conselho Nacional de Política Energética - CNPE, e regulamentada pela Resolução ANEEL nº. 353, de 22/07/2003.

132 Cumpre ressaltar que o objeto de tais leilões seria apenas o excedente de energia elétrica decorrente da liberação dos Contratos Iniciais e Equivalentes, bem como dos montantes estabelecidos nas Resoluções ANEEL nº. 267/98, 450/1998 e 451/98, compreendidos como energia de geração própria, em montantes previamente informados pelo Mercado Atacadista de Energia - MAE.
} 
celulose, conforme se verifica na Tabela 4.4. Dentre os grupos compradores, por outro lado, destaca-se o Grupo Gerdau, que adquiriu, isoladamente, 269 MW médio, representando quase $30 \%$ do total negociado, seguido pelo Grupo Alcan, com 118,2 MW médio, equivalente a $13 \%$ (ver Tabela 4.3 ).

Tabela 4.3.

Principais compradores do leilão de compra de excedente de energia elétrica, vinculados ao setores eletrointensivos..

\begin{tabular}{|c|c|c|c|c|}
\hline Comprador & $\begin{array}{l}\text { Montante } \\
\text { Negociado } \\
\text { (MW médio) }\end{array}$ & $\begin{array}{c}\text { Preço } \\
\text { inicial } \\
\text { (R\$/MWH) } \\
\text { (A) }\end{array}$ & $\begin{array}{c}\text { Preço de } \\
\text { Fechamento } \\
\text { (R\$/MWH) } \\
\text { (B) }\end{array}$ & $\begin{array}{r}\text { Variação } \\
\text { de Preços } \\
\text { (B)/(A) } \\
\text { em \% }\end{array}$ \\
\hline \multirow{2}{*}{ Albras Barabacena } & 11,00 & 47,60 & 36,96 & $-22,35$ \\
\hline & 9,00 & 50,93 & 37,91 & $-25,56$ \\
\hline \multirow{2}{*}{ Alcan Candeias } & 19,10 & 86,85 & 54,35 & $-37,42$ \\
\hline & 36,10 & 77,75 & 67,67 & $-12,96$ \\
\hline \multirow{2}{*}{ Alcan Ouro Preto } & 23,00 & 70,21 & 44,73 & $-36,29$ \\
\hline & 40,00 & 92,42 & 56,72 & $-38,63$ \\
\hline Alunorte Barcarena & 85,00 & 50,93 & 37,91 & $-25,56$ \\
\hline \multirow{2}{*}{ Ferbasa } & 1,80 & 86,85 & 54,35 & $-37,42$ \\
\hline & 118,20 & 77,75 & 67,67 & $-12,96$ \\
\hline \multirow{3}{*}{ Gerdau Açonorte } & 1,80 & 61,33 & 44,11 & $-28,08$ \\
\hline & 10,00 & 86,85 & 54,35 & $-37,42$ \\
\hline & 10,00 & 77,75 & 67,67 & $-12,96$ \\
\hline \multirow{2}{*}{ Gerdau Cosigua } & 6,10 & 68,74 & 40,90 & $-40,50$ \\
\hline & 86,90 & 92,42 & 56,72 & $-38,63$ \\
\hline Gerdau Guaíra & 37,20 & 82,18 & 62,98 & $-23,36$ \\
\hline \multirow{2}{*}{ Gerdau Piratini } & 3,00 & 65,37 & 59,97 & $-8,26$ \\
\hline & 11,80 & 82,18 & 62,98 & $-23,36$ \\
\hline \multirow{2}{*}{$\begin{array}{l}\text { Gerdau Rio } \\
\text { Grandense }\end{array}$} & 1,20 & 65,37 & 59,97 & $-8,26$ \\
\hline & 21,10 & 82,18 & 62,98 & $-23,36$ \\
\hline \multirow{3}{*}{ Gerdau Usiba } & 5,00 & 61,33 & 44,11 & $-28,08$ \\
\hline & 1,00 & 86,85 & 54,35 & $-37,42$ \\
\hline & 70,60 & 77,75 & 67,67 & $-12,96$ \\
\hline $\begin{array}{l}\text { Metalcorte Caxias do } \\
\text { Sul }\end{array}$ & 6,00 & 82,18 & 62,98 & $-23,36$ \\
\hline \multirow{2}{*}{ Norske Jaquariaíva } & 7,10 & 65,37 & 59,97 & $-8,26$ \\
\hline & 46,60 & 82,18 & 62,98 & $-23,36$ \\
\hline Sibra Simões & 89,80 & 77,75 & 67,67 & $-12,96$ \\
\hline Valesul Rio de Janeiro & 57,00 & 92,42 & 56,72 & $-38,63$ \\
\hline
\end{tabular}

Fonte: CCEE. Elaboração própria. 
Tabela 4.4.

Principais compradores do leilão de excedente de energia elétrica, por setores

\begin{tabular}{|l|r|r|}
\hline \multicolumn{1}{|c|}{ Setor } & $\begin{array}{c}\text { Volume Negociado } \\
\text { MW médio }\end{array}$ & $\begin{array}{c}\text { Participação no } \\
\text { total em \% }\end{array}$ \\
\hline Siderurgia & 365,7 & $40,1 \%$ \\
\hline Alumínio & 280,2 & $30,7 \%$ \\
\hline Ferro-ligas & 123,3 & $13,5 \%$ \\
\hline Papel e Celulose & 53,7 & $5,9 \%$ \\
\hline Outros $\left(^{*}\right)$ & 89,3 & $9,8 \%$ \\
\hline Total & 912,2 & $100 \%$ \\
\hline
\end{tabular}

(*) Inclui as empresas vinculadas ao setor de cloro/soda, fertilizantes, metal mecânica, têxtil e engenharia.

Fonte:CCEE. Elaboração própria

Quando se analisa o lado dos vendedores, cujos resultados estão consolidados na Tabela 4.5., percebe-se que a CHESF teve o melhor desempenho ao vender $47,68 \%$ do total negociado, muito em função das operações envolvendo a Alcan Candeias, Ferbasa, Gerdau Açonorte e Usiba, além da Sibra Simões Filho, que juntas arremataram 84,2\% do total vendido pela estatal. 
Tabela 4.5.

Vendedores do leilão de excedente de energia elétrica

\begin{tabular}{|c|r|r|r|}
\hline Vendedor & \multicolumn{1}{c|}{$\begin{array}{c}\text { Total } \\
\text { Ofertado } \\
\text { MW médio }\end{array}$} & $\begin{array}{c}\text { Total } \\
\text { Negociado } \\
\text { MW médio }\end{array}$ & $\begin{array}{c}\text { Participação } \\
\text { em relação } \\
\text { ao total } \\
\text { negociado } \\
\text { (em \%) }\end{array}$ \\
\hline CESP & 210,0000 & 46,8500 & 5,18 \\
\hline CGTEE & 6,0000 & 0,0000 & 0,00 \\
\hline CHESF & $1.814,0000$ & 431,3718 & 47,68 \\
\hline ELETRONORTE & 130,0000 & 105,0000 & 11,61 \\
\hline EMAE & 20,0000 & 0,0000 & 0,00 \\
\hline FURNAS & $2.593,7000$ & 243,6780 & 26,93 \\
\hline TRACTEBEL & 980,0000 & 77,8002 & 8,60 \\
\hline TOTAL & $\mathbf{5 . 7 5 3 , 7 0 0 0}$ & $\mathbf{9 0 4 , 7 0 0 0}$ & $\mathbf{1 0 0 , 0 0}$ \\
\hline
\end{tabular}

Fonte: CCEE. Elaboração própria.

Quanto ao comportamento dos preços efetuados no referido leilão, os resultados apresentados na Tabela 4.3. evidenciam que, na média, os deságios ficaram em torno de $25 \%$, tendo, novamente, o Grupo Gerdau, em especial, a empresa Gerdau Cosigua conseguido os melhores descontos, algo próximo a 39,5\%. Já em termos de distribuição regional, há a predominância da região Nordeste, que conseguiu vender $41 \%$ do total negociado, representando, porém, $36 \%$ do total por ela ofertado. Em contrapartida, a região Norte viabilizou quase a metade do que ofertado, isto é, 105,00 MW, conforme se pode verificar da Tabela 4.6. 
Tabela 4.6.

Distribuição do total ofertado, por submercado de entrega

\begin{tabular}{|l|r|r|r|}
\hline $\begin{array}{c}\text { Submercado } \\
\text { de entrega }\end{array}$ & $\begin{array}{c}\text { Total Ofertado } \\
\text { MW médio }\end{array}$ & $\begin{array}{c}\text { Total Negociado } \\
\text { MW Médio }\end{array}$ & $\begin{array}{c}\text { Participação no } \\
\text { total ofertado } \\
\text { em \% }\end{array}$ \\
\hline Norte & 220,00 & 105,00 & $47,73 \%$ \\
\hline Nordeste & $1.035,00$ & 373,40 & $36,08 \%$ \\
\hline Sul & 506,00 & 157,30 & $31,09 \%$ \\
\hline Sudeste/Centro-Oeste & $3,992,7$ & 269,00 & $6,74 \%$ \\
\hline
\end{tabular}

Fonte:CCEE. Elaboração própria

Por fim, registre-se, ainda, que do total negociado, $88 \%$ refere-se a contratos de duração de 2 anos, frente a $11,6 \%$ de um ano. Tais resultados reforçam a tendência de se buscar estabilidade de preços, se possível em prazos mais longos e com deságios maiores, consolidando, dessa maneira, a importância que as negociações, por leilões, devem assumir dentre as opções que se colocam aos poucos para os consumidores livres, categoria em que as empresas eletointensivas são majoritárias.

\subsubsection{Ambiente de contratação livre e os leilões de compra de energia para uso próprio.}

Outra estratégia que passou a ser utilizada pelas empresas eletrointensivas é a realização de leilão para compra de energia para uso próprio, promovida pelas próprias empresas, de maneira a contornar eventuais impasses relacionados ao preço de energia, em especial, em negociações de renovação de contratos de fornecimento.

Tal oportunidade, por exemplo, foi utilizada pela Albrás - Alumínio Brasileiro S/A, empresa produtora de alumínio primário, maior consumidora individual de energia elétrica do Brasil e maior cliente individual da Eletronorte, quando da renovação de seu contrato junto à estatal, fornecedora de energia elétrica para a empresa desde 1984, com a inauguração da Usina Hidrelétrica de Tucuruí, no Rio Tocantins. Isto porque, a Vale do Rio Doce, controladora da Albrás ${ }^{133}$, ofereceu à Eletrobrás, controladora da Eletronorte, uma

\footnotetext{
${ }^{133}$ A empresa está instalada em Barcarena, no Pará e foi constituída no final dos anos 70, resultado de um acordo binacional entre os governos do Brasil e do Japão e tem como acionistas a Companhia Vale do Rio Doce, com 51\% do capital, e a NAAC - Nippon Amazon Aluminium Co. Ltd, uma associação de 32 empresas
} 
contraproposta de compra de energia pelo valor de US\$ 16 por MW, ante uma proposta de US\$ 27 a US\$ 30 o MW, oferecido pela estatal. Como o impasse não foi solucionado, a Albrás decidiu promover um leilão de compra de energia, em 03 de maio de 2004, dividido em 10 lotes, tendo o fornecimento sido disputado pela Eletronorte, Furnas e CESP.

Ao final, saiu-se vencedora a própria Eletronorte, que permanecerá como supridora da Albrás, por mais 20 anos, enviando à empresa 750 MW médios de 2004 até o fim de 2006, e 800 MW médios, do início de 2007 a 31 de dezembro de 2024, o que equivale a $20 \%$ da capacidade de geração da primeira fase da Usina Hidrelétrica de Tucuruí, ou seja, 4.000 MW. A empresa de alumínio concordou em pagar US\$ 18,00 por MWh (R\$53,00 por MWh), atualizando o contrato anterior, que tinha um preço de US\$11,00 por MWh, corrigido pela variação anual do IGP-M, além de pagar um bônus adicional à Eletronorte sempre que preço do alumínio primário exceder US\$1.450/ton, de acordo com a cotação da London Metal Exchange (LME).

Já o valor total do contrato foi estabelecido em US\$ 3,4 bilhões, o que permite que a Eletronorte receba o equivalente a US\$ 170 milhões por ano, com a antecipação de R\$ 1,2 bilhão, em quatro parcelas a partir de junho de 2004, de maneira a dar continuidade às obras de duplicação da referida usina, que até final de 2006 deverá estar gerando 8.370 MW.

$\mathrm{Na}$ seqüência, outro contrato de fornecimento de energia, agora envolvendo a Eletronorte e o Consórcio Alumínio do Maranhão - Alumar ${ }^{134}$, foi renegociado seguindo os mesmos parâmetros anteriormente definidos. Em leilão de compra de energia promovido pelo consórcio, em maio de 2004, para fornecimento de carga média de $820 \mathrm{MW}$ de energia para fábrica de alumínio localizada no Maranhão, pelos próximos 20 anos, a Eletronorte consagrou-se, novamente, vencedora.

$\mathrm{Na}$ verdade, embora o leilão tenha sido aberto à participação de todas as geradoras, sejam elas privadas ou públicas, não houve nem mesmo um ensaio de disputa, levando ao entendimento de que a renovação do contrato já havia sido acordada previamente, pelo

\footnotetext{
japonesas com $49 \%$ do capital.

${ }^{134}$ O Consórcio de Alumínio do Maranhão, ALUMAR, é formado pelas empresas, ALCOA, ALCAN, BHPBILLITON e ABALCO e é um dos maiores complexos de produção de alumínio e alumina do mundo, tendo sido implantando em julho de 1980.
} 
lance máximo de US\$20,00 por MWh, oferecido pela Alunorte, muito próximo ao valor até então praticado no contrato, ou seja, US\$22,00 por MWh. Com este segundo contrato, a estatal irá receber cerca de US\$ 4 bilhões até 2024, sendo que a energia assegurada pelo leilão também será gerada pela Usina Hidrelétrica de Tucuruí.

Os dois contratos juntos (Albrás e Alumar) permitiram que a Eletronorte se tornasse a maior fornecedora de energia em bloco do País, com a entrada de R 79 milhões todos os meses no caixa da Eletronorte, uma vez que o valor total dos contratos somados - US\$ 7,4 bilhões - representa mais que o dobro do patrimônio líquido da Eletronorte.

Em 19 de novembro de 2004, a Eletronorte conquistou mais um novo contrato com outra grande consumidora de energia. Desta vez, a geradora venceu o leilão para fornecimento de $170 \mathrm{MW}$ médios anuais, ou 23,22 milhões de MWh/ano, para as futuras instalações da unidade mínero-metalúrgica que a Onça Puma, subsidiária da canadense Canico Resource Corp., está implantando em Ourilândia do Norte, no sul do Pará, para a mineração de níquel aliada a uma indústria metalúrgica para a produção de ferro níquel.

Em leilão realizado pela comercializadora Enecel, a Eletronorte venceu a disputa em que também concorriam as geradoras Chesf, Furnas, Cesp e Tractebel apresentando a melhor oferta para custo/flexibilidade de fornecimento de energia. A estatal, que fornecerá energia por 16 anos, a partir de julho de 2007, propôs um valor próximo a R \$ 70 por MWh, reajustáveis pelo IGP-M, e uma possibilidade de consumo de até 5\% variável, para mais ou para menos. O contrato inclui, além do fornecimento de energia, a construção de um sistema de transmissão, com 400 km de extensão, entre Marabá (PA) e Ourilândia, em 230 $\mathrm{kV}$, para conexão da unidade industrial ao sistema da Rede Básica, cuja obra, estimada em R\$ 150 milhões, será financiada pela mineradora, ressaltando que, no total, o contrato totalizará R\$ 1,75 bilhão ou cerca de US\$ 620 milhões.

Segundo informações, a Onça-Puma planeja investir no país recursos da ordem de US\$ 900 milhões para produção de 44 mil toneladas de ferro-níquel por ano. Com isso, a mina localizada na região dos municípios de Ourilândia do Norte, São Félix do Xingu, Tucumã, Parauapebas e Água Azul do Norte, que possui cerca de 104 milhões de toneladas de níquel laterítico, deve ter entre 45 e 50 anos de vida útil.

Apenas para ilustrar, de maneira extremamente simplificada, o benefício que as 
operações trouxeram para as empresas, pode-se realizar o seguinte cálculo: a) em 2004, ano das renovações dos contratos de energia efetuados pela Eletronorte, a tarifa média de fornecimento praticada pela ANEEL, na região Norte, para classe de consumo industrial, era de $\mathrm{R} \$ 110,13 / \mathrm{MWh}$; b) convertendo essa tarifa pela taxa de câmbio, em dólar médio comercial, registrada no mesmo período, ou seja, 1 US\$/R $\$ 2,94$, obtém-se o valor de US\$ 37,46/MWh; e c) o resultado final equivale a um deságio na tarifa contratada em relação ao valor registrado pela ANEEL, em torno de, respectivamente, $52 \%, 47 \%$ e de $36,5 \%$, para Albrás, Alumar e Onça-Puma.

Assim, percebe-se que as empresas eletrointensivas vêm buscando, efetivamente, fechar bons negócios, em particular em momentos de renegociação das tarifas, com oportunidades de obtenção de prêmios nos preços contratados, no Ambiente de Contratação Livre, a partir de leilões de compra para uso próprio. Essa estratégia pode compensar os empreendimentos paralisados, caso a atratividade na autoprodução não se efetive em decorrência das restrições ambientais impostas aos projetos de expansão. 


\section{CONSIDERAÇÕES FINAIS}

As páginas anteriores tentaram resgatar a evolução do setor elétrico brasileiro, caracterizando dois períodos bem específicos, quais sejam: a) de 1934 a 1989, marcado pela ação efetiva do Estado no setor, ao assumir a tarefa de indutor e formulador das políticas setoriais, consolidando sua posição de agente principal; e b) de 1990 a 2005, onde se verifica a passagem de um padrão de intervenção estatal para um modelo mercantil privado, com destaque para as diversas adaptações vivenciadas pelo setor ao longo do biênio 2003/2004. Evidentemente, que essa periodização não é uma particularidade do setor elétrico brasileiro, mas revela uma estreita relação com os princípios econômicos dominantes em cada uma das etapas demarcadas.

Conforme visto no primeiro capítulo, durante os anos compreendidos entre a $2^{\mathrm{a}}$ Guerra Mundial e a década de 70, prevaleceu a intervenção econômica direta do Estado, preconizada por Keynes, em dois vetores básicos de atuação: i) na expansão e generalização dos mecanismos de garantia de renda, expressa no sistema de transferência, bem como na ampla expansão da prestação de serviços sociais, principalmente educação, saúde e infra-estrutura urbana; e ii) no envolvimento crescente do Estado, direto e indireto, na produção de bens e serviços.

$\mathrm{Na}$ verdade, com esses fundamentos, Keynes deixava claro seu ceticismo em relação ao mercado, por acreditar que se a economia fosse abandonada à sua lógica, correria um sério risco de funcionar em crise. Por esse motivo, defendia a intervenção econômica direta do Estado sobre o volume de investimentos, de maneira a induzir a criação de empregos, compensando, dessa forma, a eventual insuficiência das empresas privadas.

Assim, o amplo consenso acerca das limitações do mercado permitiu a adoção de uma orientação de política econômica centrada, principalmente, na presença do Estado na atividade econômica nacional, em uma política fiscal garantidora da execução de políticas de renda e de administração da demanda agregada, e nas despesas públicas, como principal motor de uma fase continuada de expansão econômica.

Como resultado, a economia mundial pode vivenciar, por quase trinta anos, um expressivo crescimento, em decorrência da forte atuação estatal, tendo os gastos públicos como principal fator anticíclico do período. 
A partir de meados da década de 70, entretanto, esse receituário keynesiano dá mostras de que é incapaz de impedir a crise de superacumulação, decorrente do processo de acumulação de capital das principais economias avançadas.

Dessa forma, em meados da década de 80 , em um contexto marcado por estagnação, verifica-se o retorno às práticas de políticas econômicas mais ortodoxas, centradas em um enfoque monetário restritivo e na austeridade fiscal, através de expressivos cortes nos gastos públicos correntes, incluindo seus investimentos produtivos. Neste ambiente, tornase defensável a adoção de programas de privatização, com a desverticalização de muitos dos setores responsáveis sobre a execução de serviços públicos, incluindo energia elétrica, sob a justificativa de terem se tornado ineficiente sob mãos públicas. Tal conduta, conforme destacado no capítulo 1, encontra respaldo na onda de inovações tecnológicas, basicamente, nos avanços experimentados nos segmentos da microeletrônica e das telecomunicações.

Completando essa lógica que evidencia a revisão do papel do Estado na economia, é montado um novo sistema institucional/regulatório eficiente, com o propósito de regular tais serviços, agora parcialmente realizados pela iniciativa privada, de maneira a contornar eventuais falhas de mercado.

Nessa circunstância, duas questões deveriam ganhar destaque. A primeira refere-se à própria caracterização da evolução da regulação econômica, que passaria a assumir a coordenação, regulamentação e fiscalização de aspectos das políticas e dos procedimentos gerais de cada setor. Já a segunda centra-se na própria atuação do Estado, no sentido de definir políticas de caráter estratégico para o desenvolvimento nacional e, particularmente, para o setor elétrico.

$\mathrm{Na}$ verdade, o ponto central relacionado a essas questões é a defesa de que deva continuar existindo uma articulação, sob a coordenação do Estado, entre o que se pretende em termos de desenvolvimento nacional para o País, explicitados, por exemplo, em uma política industrial, e a capacidade de determinados setores estratégicos, como o elétrico, em contribuir para esse fim.

Foi, exatamente, com esse propósito que a presente tese de doutorado foi estruturada. Após situar o leitor, em seu primeiro capítulo, sobre os aspectos relacionados à evolução do Estado, da regulação econômica e políticas públicas, o trabalho passou a detalhar o desenvolvimento do setor elétrico brasileiro. 
No segundo capítulo, a ênfase foi demonstrar, inicialmente, o esforço do governo federal, em particular durante a gestão do Presidente Getúlio Vargas, em definir, claramente, a responsabilidade e o papel a ser assumido por cada um dos agentes envolvidos na tarefa de viabilizar o processo de industrialização nacional, com destaque para a construção de formas internas de financiamento, capazes de permitir os investimentos públicos nos diversos segmentos da infra-estrutura brasileira.

Na seqüência, o trabalho passou a descrever o modelo institucional e econômicofinanceiro, montado para o setor, em especial entre os anos de 1964 a 1979, quando viveu seu grande período de expansão, ao permitir a ampliação da capacidade instalada de energia elétrica, em 1979, para 27.970 MW, configurando um aumento de 82,5\% em apenas seis anos, tendo como base o ano de 1973.

Apesar de tal desempenho, foi justamente ao final deste ciclo de crescimento que se evidenciaram os principais problemas do setor, explicitados, de um lado, pela sua subordinação aos interesses da política macroeconômica, nem sempre sintonizada aos objetivos setoriais, e de outro, dadas às contradições internas do próprio modelo institucional e econômico-financeiro organizado para o setor.

De fato, conforme foi demonstrado no segundo capítulo, durante esse período, o setor elétrico brasileiro viveu um acentuado quadro de endividamento externo e interno, resultado, em parte, da estratégia de crescimento econômico adotada durante os anos 70, que se valeu da entrada de recursos externos, boa parte deles captados via empresas do setor elétrico estatal, como sua principal fonte de financiamento, e do modelo institucional desenhado, que acabou se revelando inadequado, em razão da intensificação dos conflitos federativos. Além disso, as restrições de investimento no setor, em decorrência do esgotamento do padrão de financiamento público, já revelavam, naquela ocasião, os limites de sua expansão, particularmente nos segmentos de geração e transmissão.

Dessa forma, é neste ambiente que se inicia o segundo período de evolução do setor elétrico brasileiro, cujo processo de reestruturação vivenciado, particularmente, entre 1995 e 2002, conforme detalhado ao longo do terceiro capítulo, torna-se sua marca principal.

$\mathrm{Na}$ verdade, percebe-se claramente que as ações governamentais, classificadas como políticas horizontais, foram, nas últimas duas décadas, amplamente difundidas e implementadas em diversos países, variando apenas a intensidade e a eficiência, na 
condução de cada uma delas.

Nesse particular, o terceiro capítulo, ao caracterizar as principais mudanças ocorridas no âmbito da reestruturação encaminhada para o setor elétrico brasileiro, na década de 90, concentrou-se, de um lado, na busca da construção de um quadro institucional e regulatório estáveis, e de outro, na identificação dos elementos essenciais para garantir a eficiência econômica pelo próprio mercado, reduzindo, assim, a necessidade de implementação de um planejamento estratégico para o setor.

A nova estratégia para o setor alinhada aos mecanismos e à dinâmica do mercado e sob a égide da ordem econômica predominante acaba por inibir outras tentativas de reestruturação do setor, que poderiam advir, por exemplo, da articulação das políticas de desenvolvimento nacionais à expansão planejada do setor. A crise de abastecimento ocorrida em 2001 expõe os limites da estratégia adotada, conforme explicitado no item 3.3.1.

Com a posse do Presidente Lula foi montado um Grupo de Trabalho com o objetivo de assessorar na formulação de uma reforma institucional para o setor que privilegia os seguintes objetivos: a) modicidade tarifária para os consumidores; b) prevalência do conceito de serviço público; c) mitigação dos riscos sistêmicos; d) universalização do acesso e uso dos serviços; e e) transparência e contestação pública.

A partir desses objetivos, são definidos os papéis a serem assumidos pelos principais agentes e suas respectivas funções, de maneira a resgatar os princípios do planejamento do setor, buscando assegurar o suprimento, tal como discutido ao final do terceiro capítulo. Além disso, o modelo desenhado propõe a coexistência de dois ambientes de contratação, a saber: a) Ambiente de Contratação Regulada (ACR), caracterizado por tarifas de suprimento reguladas através da compra de energia pelo conjunto das distribuidoras; e b) Ambiente de Contratação Livre (ACL), em que geradoras e produtores independentes comercializarão energia com preços e quantidades livremente negociados com os consumidores livres.

É interessante verificar a adaptação das indústrias eletrointensivas, a este novo contexto, o que está amplamente discutido no capítulo quarto. Assim, constata-se que para assegurar o recebimento da energia necessária e dar suporte a sua expansão, elas têm recorrido aos leilões de compra de energia no Ambiente de Contratação Livre, pretendendo 
com isso não apenas garantir o abastecimento, minimizando seus riscos, mas também reduzir consideravelmente os valores médios pagos a energia contratada.

Em paralelo, à revisão do modelo institucional do setor elétrico, a gestão do Presidente Luis Inácio Lula da Silva, em novembro de 2003, divulgou as linhas básicas que fundamentam a chamada Política industrial, Tecnológica e de Comércio Exterior - PITCE, para o País. Dentre os principais pontos destaca-se a linha de ação denominada "Atividades Portadoras de Futuro", que centra-se em ampliar as vantagens competitivas brasileiras, tendo em vista o potencial que áreas como biotecnologia, biomassa e biocombustíveis podem exercer em setores disseminadores de inovação diferenciada. Dessa forma, o desafio que se impõe é transformar essa linha de ação em políticas ativas de governo, o que torna oportuna a discussão sobre o papel que as fontes alternativas de energia, em especial os biocombustíveis, poderia assumir na pauta de exportação brasileira, não apenas exportando seu produto primário, mas também na capacidade de inovação tecnológica, decorrente de seu desenvolvimento, abrindo espaço para revisão da estratégia, por exemplo, de outras cadeias exportadoras, tal como a da indústria eletrointensiva.

Percebe-se, portanto, que a atuação do Estado nesse novo contexto não deve ser minimizada. Resgatar o papel do Estado na rearticulação do quadro institucional, de maneira a sair fortalecido na coordenação da política energética nacional é de fundamental importância. No fundo, esse tipo de discussão recoloca a própria estratégia de reestruturação do setor elétrico nacional, ao avaliar que tipo de modelo organizacional se pretende e como esse setor pode ser contemplado por políticas verticais ativas, voltadas, por exemplo, para a promoção da expansão de sua capacidade instalada, bem como para revisão da inserção do país no cenário mundial, tendo em vista a relevância que o insumo energia deve assumir em um processo de retomada do crescimento econômico nacional. 


\section{REFERÊNCIAS BIBLIOGRÁFICAS}

Abreu, M.P. A (et alli) A ordem do progresso: cem anos de política econômica republicana,1889-1989, Rio de Janeiro, Editora Campus, 1990.

Alem, A.C. Barros, J.R.M.L., Giambiagi, F. Bases para uma política industrial moderna, in Leite, A.D. \& Velloso, J.P.R.(coord.) O Novo Governo e os Desafios do Desenvolvimento, Fórum Nacional, Instituto Nacional de Altos Estudos INAE, Rio de Janeiro, pp. 657-680, 2002.

Alveal, C. A descentralização regulatória das indústrias de energia no Brasil: reformas estruturais do estado e dilema federativo. in Borenstein, C. R. (coord.) Regulação e Gestão Competitiva no Setor Elétrico Brasileiro, pp. 125-141, Ed. Sagra Luzzato, 1999.

Aneel, Descentralização: aspectos gerais: 2005, Brasília-DF, Aneel, 2005.

Araújo. J.L. Regulação de monopólios e mercados: questões básicas. Trabalho Temático para o I Seminário Nacional do Núcleo de Economia da Infra-estrutura, 1997.

. A Questão do investimento no setor elétrico brasileiro: reforma e crise, Rio de Janeiro, Instituto de Economia, s/d, mimeo.

Araújo, J.T.Jr. Concorrência, competitividade e política econômica, in Baumann, R.(org.) O Brasil e a Economia Global, Rio de Janeiro: Campus: Sobeet, pp. 75-108, 1996.

Baer, W. A Economia Brasileira, São Paulo: Nobel, 1996.

Bajay, S.V. Uma nova concepção de planejamento energético para o Brasil, As perspectivas do setor elétrico após o racionamento in Soluções para energia no Brasil, IX Congresso Brasileiro de Energia, Volume I, pp. 893-898, Volume I, Anais 2002.

Uma revisão crítica do atual planejamento da expansão do setor elétrico brasileiro in Soluções para energia no Brasil, IX Congresso Brasileiro de Energia, Volume I, pp. 899-905, Volume I, Anais 2002.

Baumol, W.J. Contestable markets: an uprising in the theory of industry structure, The American Economic Review 72 (1), março, pp 1-15, 1982.

Bermann, C. A energia elétrica incorporada na exportação: aspectos tecnológicos, econômicos e sócio-ambientais para o estudo da demanda dos setores industriais eletrointensivos - um ensaio multidisciplinar. Tese de Livre Docência. Instituto de Eletrotécnica e Energia da USP, mimeo, julho, 2006.

Exportando a nossa natureza. Produtos intensivos em energia: implicações sociais e ambientais. Série Cadernos sobre comércio e meio ambiente, $\mathrm{n}^{\mathrm{o}} 1$, Rio de Janeiro: Projeto Brasil Sustentável e Democrático: FASE, 2004. 
Energia no Brasil: Para quê? Para quem? Crise e alternativas para um país sustentável. Editora Livraria da Física - FASE - Federação de Órgãos para Assistência Social e Educacional, São Paulo, 2002(a).

- Indústrias eletrointensivas e autoprodução: propostas para uma política energética de resgate do interesse público. mimeo, 2002 (b).

Branco, O.C., Sampaio, A.S.B. O acordo geral do setor elétrico, em OESP de 12/07/2002.

Brunetti, J., Guerra, S. Limites da política tarifária na reforma do setor elétrico brasileiro. Trabalho apresentado no VII Congresso Brasileiro de Energia, 1996.

Brunhoff, S. A Hora do Mercado: crítica do liberalismo. São Paulo, Editora Universidade Estadual Paulista, p. 182, 1991.

Canuto, O. O Consenso de Aracaju: os princípios do "Consenso de Washington" não são aplicáveis e muito menos auto-suficientes. Estado de São Paulo, em 08/08/2000.

Carvalho, J.F., Januzzi, G.M. Aspectos éticos do modelo de planejamento do setor elétrico, Revista Brasileira de Energia, Vol. 3, 1994.

Carvalho, J.F. Esboço de uma política energética para o Brasil, mimeo, 2002.

Coase, $R$. The firm, the market and the law. 1988.

Coopers \& Lybrand A reestruturação do setor elétrico brasileiro: sumário executivo, mimeo, 1997.

Costa, H.B. Um depoimento histórico de Catullo Branco, in Branco, A.M. (org.) Política Energética e Crise de Desenvolvimento. A Antevisão de Catullo Branco, Editora Paz e Terra S/A, São Paulo, pp. 43-79, 2002.

Coutinho, L. Percalços e problemas da economia mundial capitalista. Estado, estagflação e riscos financeiros, in Belluzzo, L.G.M. \& Coutinho R. (org.) Desenvolvimento Capitalista no Brasil v. 1: ensaios sobre a crise. Instituto de Economia da Unicamp, $4^{\text {a }}$ Edição, pp. 4567, 1998.

Qual o desenvolvimento que queremos? Valor Econômico, de 28/07/2006.

Cruz, P.D. Notas sobre o endividamento externo brasileiro nos anos setenta, in Belluzzo, L.G.M. \& Coutinho R. (org.) Desenvolvimento Capitalista no Brasil $n .^{\circ}$ 2: ensaios sobre a crise. Editora Brasiliense, $2^{\mathrm{a}}$ Edição, pp. 61-106, 1983.

Cysne, R.P. Doença Holandesa ou comércio insuficiente? Valor Econômico, São Paulo, 23/02/2006.

Draibe, S. Rumos e metamorfoses: um estudo sobre a constituição do Estado e as 
alternativas da industrialização no Brasil, 1930-1960. Rio de Janeiro: Paz e Terra, 1985.

Erber, F.S., O retorno da política industrial, in Leite, A.D. \& Velloso, J.P.R.(coord.) $O$ Novo Governo e os Desafios do Desenvolvimento, Fórum Nacional, Instituto Nacional de Altos Estudos INAE, Rio de Janeiro, pp. 635-656, 2002.

Política industrial no Brasil - um quadro analítico e algumas propostas. Texto para Discussão n ${ }^{\circ}$ 136, Rio de Janeiro: Instituto de Economia Industrial, UFRJ, P. 1-21, dezembro, 1987.

Ferreira, C.K.L. Privatização do Setor Elétrico no Brasil, in Pinheiro, A.C. e Fukusaku (editores) A Privatização no Brasil: o caso dos serviços de utilidade pública, OCDEBNDES/Finame-BNDESPAR, Rio de Janeiro, pp. 179-220, fevereiro, 2002.

Gilbert, R., Kahn, E. P. (org.) International Comparisons of Electricity Regulation. Cambridge University Press, s/d.

Gomes, A.C.S. et alli O Setor Elétrico, in BNDES 50 anos - Histórias Setoriais, Publicações BNDES, pp. 1-21, dezembro, 2002.

Gomes, F.B.M., Monnerat, S.B. A Questão regulatória no Brasil: situação atual e Perspectivas, Revista BNDES, Rio de Janeiro, V.3., N.6, P. 189-200, dezembro, 1996.

Gonçalves, R. Comércio Exterior Brasileiro: evolução, características e tendências. Fase: Solidariedade e Educação, Rio de Janeiro, mimeo, setembro, 2003.

Gremaud, A.P., Vasconcellos, M.A.S., Toneto, R. Economia Brasileira Contemporânea, $6^{\mathrm{a}}$ edição, São Paulo, Atlas, 2005.

Guimarães, E.A. A experiência recente da política industrial no Brasil: uma avaliação Texto para Discussão no 326, Rio de Janeiro: Instituto de Economia, UFRJ, P. 1-39, s/d.

Hunt, E.K. História do Pensamento Econômico: uma perspectiva crítica, Rio de Janeiro, Editora Campus, p. 541, 1982.

Hunt S., Shuttleworth G. Competition and Choice in Electricity. West Sussex: Willey, 1996.

Ianni, O. Estado e planejamento econômico no Brasil, 1930-1970, Rio de Janeiro, Civilização Brasileira, 1971.

Instituto Cidadania. Diretrizes e linhas de ação para o setor elétrico brasileiro, Projeto Energia Elétrica, abril, 2002.

IPEA Diretrizes de Política Industrial, Tecnológica e de Comércio Exterior, Ministério do Desenvolvimento, Indústria e Comércio, p. 23, novembro, 2003. 
Keynes, J.M. A Teoria Geral do Emprego, do Juro e da Moeda, São Paulo, Atlas, p. 382, 1982.

Lafer, C. O Planejamento no Brasil: Observações sobre o Plano de Metas (1956-1961), in Lafer, B.M. (org.) O Planejamento no Brasil, Editora Perspectiva S.A., 1970.

Laffont, J. J., Tirole, J. A theory of procurement and regulation, 1993.

Landi, M. Política Econômica e Privatização: a experiência brasileira do período (1985/1997), Tese de Mestrado, Programa de Estudos Pós-Graduados em Economia Política, PUC, São Paulo, 1998.

A Privatização Brasileira: a agenda da atual gestão, Boletim de Conjuntura Econômica, PUC/SP, dezembro, 1996.

Landi, M., Bermann, C. A reestruturação do setor elétrico brasileiro: uma transição incompleta. In: Soluções para energia no Brasil, IX Congresso Brasileiro de Energia, Volume I, pp. 379-385, Anais 2002.

Landi, M., Pessini, J.E. V - Infra-estrutura econômica e empresas estatais, in Portugal Jr., J. G., Sampaio, F.A.A. (org.) Gestão estatal no Brasil: o governo Itamar Franco: 1992-1994, São Paulo, Fundap, pp. 130-145, 1998.

Lessa, C. 15 anos de Política Econômica, Editora Brasiliense, 4ª edição, 1983.

Lima, J.L. Estado e Energia no Brasil. O setor elétrico no Brasil: das origens à criação da Eletrobrás (1890-1962), IPE/USP, São Paulo, 1984.

Políticas de governo e desenvolvimento do setor de energia elétrica: do Código de Águas à crise dos anos 80 (1934-1984). Memória da Eletricidade, Rio de Janeiro, 1995.

Mackeron, G. Regulation and the economic outcomes of electricity privatisation in England and Wales. Revue de l'Énergie, n. 465, janvier-février, pp. 77-83. 1995.

Marques Neto, F.A. Agências reguladoras: instrumentos e fortalecimento do Estado. Associação Brasileira de Agências de Regulação - ABAR, p. 63, s/d.

Ministério de Minas e Energia. Proposta de Modelo Institucional do Setor Elétrico, julho, 2003.

Nassif, A. Há evidências de desindustrialização no Brasil? Texto de Discussão $n^{\circ} 108$, BNDES, p. 36, Rio de Janeiro, julho, 2006.

Nelson, R. \& Winter S. An evolutionary theory of economic change. Harvard University Press, 1982.

Nunes, E. O Quarto Poder - gênese, contexto, perspectivas e controle das agências 
regulatórias. mimeo, outubro, 2001.

Ocana, C. Trends in the Management of Regulation: a comparasion of Energy Regulators in: OECD Member Countries, Energy Diversification Division of the IEA, september 2002.

Oliveira, F. A Economia da Dependência Imperfeita. Rio de Janeiro. Edições Graal, 4a Edição, 1984.

Orenstein, L., Sochaczewski, A.C. Democracia com Desenvolvimento: 1956-19061 in: Abreu (org. ) A Ordem do Progresso: cem anos de política econômica republicana 18891989. Editora Campus, 1990.

Pedrosa. P. Desafios da regulação do setor elétrico, modicidade tarifária e atração de investimentos. Texto para discussão - I. ANEEL, Brasília, 2005.

Pereira, M.G., Carpio, L.G.T. Esgotamento do Modelo Regulatório do setor elétrico brasileiro: aspectos teóricos e práticos, in: Soluções para Energia no Brasil, IX Congresso Brasileiro de Energia, Volume I, pp. 402-409, Anais 2002.

Pires, J.C.L., Giambiagi, F., Sales As Perspectivas do Setor Elétrico após o Racionamento. In: Revista do BNDES, Rio de Janeiro, V 9, N.18, p163-204, dezembro de 2002.

Pires, J.C. L., Goldstein, A. Agências Reguladoras Brasileiras: Avaliação e Desafios, Revista do BNDES, Rio de Janeiro, V.8, N.16, p. 3-42, dezembro, 2001.

, Reestruturação competitiva e regulação nos setores de energia elétrica e telecomunicações. Rio de Janeiro, Instituto de Economia, UFRJ, 1999.

Pires, J.C.L., Piccini, M.S. A regulação dos setores de infra-estrutura no Brasil. in: Giambiagi, F. Moreira, M.M. (org.). A Economia Brasileira nos anos 90. Rio de Janeiro: BNDES, 1999.

Pinheiro, A.C., Giambiagi, F., Gostkorzewicz, J. O desempenho macroeconômico do Brasil nos anos 90. In: Giambiagi, F. Moreira, M.M. (org.). A Economia Brasileira nos anos 90. Rio de Janeiro: BNDES, 1999.

Porto, L.C.F., França, G. Cavalho, C.H., Oertel, L. Políticas de Energia Alternativas Renováveis, In: Soluções para Energia no Brasil, IX Congresso Brasileiro de Energia, Volume I, pp. 906-911, Volume I, Anais 2002.

Possas, M.L., Ponde, J.L., Fagundes, J.Regulação da Concorrência nos Setores de InfraEstrutura no Brasil: Elementos para um Quadro Conceitual, in Infra-estrutura: perspectivas de reorganização - Setor Elétrico. Ministério do Planejamento e Orçamento. Instituto de Pesquisa Econômica Aplicada. Brasília. IPEA. pp.81-113, 1997.

Prado, S.R.R. Intervenção estatal, privatização e fiscalidade: um estudo sobre a constituição e crise do setor produtivo estatal no Brasil e os processos de privatização a 
nível mundial. Dissertação (Doutorado) - Instituto de Economia de Campinas, dezembro, 1994.

Prado, S.R.R (org.) Processo de privatização no Brasil: a experiência dos anos 1990-92, Relatório de Pesquisa 11, Fundap/IESP, março, 1993.

Rego, J.M. \& Marques, R.M. Economia Brasileira, Editora Saraiva, 2002, $4^{\text {a }}$ tiragem.

Rodrigues A. P. \& Dias D. S. Estado e energia elétrica: experiências internacionais de regulação e o caso brasileiro, Instituto Liberal, p147, 1994.

Rosa, L.P., Tolmasquim, M. T.e Pires, J.C.L. A Reforma do Setor Elétrico no Brasil e no mundo: uma visão crítica. Relume Dumará, Rio de Janeiro, 1998.

Sá, E. K. Privatização do setor elétrico na Inglaterra e reflexões para o caso brasileiro, Revista do BNDES, Rio de Janeiro, V 2, N.3, p127-150, junho de 1995.

Salgado, L.H. Agências regulatórias na experiência brasileira: um panorama do atual desenho institucional, Rio de Janeiro, IPEA, Texto de Discussão nº 941, março, 2003.

Santana, E.A. Gomes, A.M.C. A reestruturação da indústria de rede: uma avaliação do setor elétrico brasileiro in: Borenstein. C.R. (et alli) Regulação e gestão competitiva: no setor elétrico brasileiro. Porto Alegre. Editora Sagra Luzzatto, 1999.

Santana, E.A. Oliveira, C.A. Regulação e coordenação: duas fontes de ineficiência da indústria de energia elétrica in: Borenstein. C.R. (et al) Regulação e Gestão Competitiva: no setor elétrico brasileiro. Porto Alegre. Editora Sagra Luzzatto, 1999.

Sauer, I. Um novo modelo para o setor elétrico brasileiro, Universidade de São Paulo, Programa Interunidades de Pós-graduação em Energia, dezembro, 2002.

Takahata, D. Custos de Transporte de Energia Elétrica - análise de metodologias. Dissertação (Mestrado) Escola Politécnica da Universidade de São Paulo - USP, São Paulo, 1997.

Tavares, M.C. Da substituição de importações ao capitalismo financeiro. Ensaios sobre economia brasileira. Zahar Editores, 10ª Edição, Rio de Janeiro, 1982.

Tenenbaum, B. et alii Electricity privatization: Structural, competitive and regulatory options, Energy Policy, December, pp. 1134-1160, 1992.

Velasco Jr., L, A economia política das políticas públicas: fatores que favoreceram as privatizações no período 1985/94, Texto de Discussão nº 54, BNDES, abril, 1997.

Vianna, S.B. Duas tentativas de estabilização: 1951-1954, in Abreu, M.P. (org.) A Ordem do Progresso: cem anos de política econômica republicana 1889-1989, Editora Campus, $17^{a}$ Tiragem, Rio de Janeiro, 1990. 
Vickers, J., Yarrow, G. Privatization: an economic analysis. MIT Press, 1998.

Veira, J. A energia elétrica como antimercadoria e sua metamorfose no Brasil: a reestruturação do setor $e$ as revisões tarifárias. Tese de Doutorado do Programa Interunidades de Pós-Graduação em Energia - EP/FEA/IEE/IF da Universidade de São Paulo, p. 208. 2005.

Villela, A.V, Maciel, C.S. A regulação do setor de infra-estrutura econômica: uma comparação internacional, Texto para Discussão nº 684, IPEA, Brasília, novembro, 1999.

Viscusi, K., Vernon, J. and Harrington, J. Economics of Regulation and Antitrust. The MIT Press, 1995.

Wangensteeen, I. \& Holtan, J.A. The Reform of the Norwegian Power Industry. Revue de l’Énergie, n. 465, janvier-février, pp 84 - 92. 1995 


\section{ANEXO: AS EXPERIÊNCIAS INSTITUCIONAIS E REGULATÓRIAS DE PAÍSES SELECIONADOS: os casos inglês, norueguês e argentino}

Como forma de ilustrar a base referencial tratada ao longo do texto, segue uma breve síntese dos modelos regulatórios inglês, norueguês e argentino, selecionados de forma a contemplar as diversas questões relacionadas ao tema da regulação econômica, com ênfase em suas características institucionais e os padrões de intervenção tarifária.

O caso inglês foi escolhido, dada sua opção de reestruturação, marcado pela desverticalização do setor, destacando a liberalização do mercado de comercialização de energia e os estímulos contratuais estabelecidos pela Office of Electricity Regulation OFFER.

É sabido que, antes das reformas, o setor elétrico inglês era fundamentalmente estatal, centralizado no Central Electricity Generating Board - CGEB-, detentor do monopólio da geração e transmissão de eletricidade na Inglaterra e no País de Gales ${ }^{135}$. O CGEB era provedor de $95 \%$ da demanda através de suas centrais e controlava as principais redes de transmissão, sendo responsável, também, por supervisionar e especificar os novos projetos, orientando, assim, as decisões de investimento ${ }^{136}$. A rede de distribuição, por outro lado, mantinha-se monopólio de 12 Comissões de Áreas, denominadas Regional Electricity Boards, responsáveis pela distribuição de eletricidade nos mercados regionais, desses dois países.

Na Escócia, o Estado detinha o monopólio do setor, configurado entre a South Scotland Electricity Board - SSEB - e a North Scotland Hydro Electricity Board - NSHEB. Tais empresas eram verticalmente integradas, dispondo de linhas de transmissão, que as ligavam ao mercado inglês. Ressalte-se que a primeira empresa abastecia a região sul do país, predominantemente industrial, cabendo o abastecimento da região rural, ao norte, à segunda empresa.

Com esta estrutura, foram realizados, ao longo das décadas de 60 e 70, amplos investimentos na área de geração, ocasionando, inclusive, excesso de capacidade na

\footnotetext{
${ }^{135}$ Através do Electricity Act, de 1957, foi definida esta estrutura do setor elétrico inglês, orientada pela desverticalização da geração, transmissão, distribuição, a cargo das empresas regionais, como será visto a seguir.

${ }^{136}$ Rodrigues, A. P. \& Dias, D.S. (1994).
} 
geração, cujos custos, durante os anos 80 , foram repassados aos consumidores ${ }^{137}$.

De forma a impulsionar a competição no segmento de geração, em 1983, foi publicado um novo Act, com o objetivo de remover as barreiras legais existentes para a entrada de produtores independentes na geração de energia elétrica.

Tal medida, infelizmente, dado o domínio do CEGB, no controle da rede nacional de transmissão, que, como conforme Sá (1995) usufruía de suficiente poder econômico e mercadológico para impedir ou inibir a entrada de novos produtores na geração, acabou não funcionando, em especial dada a ausência de mecanismos contra eventual discriminação de preços, que pudesse ser praticado pela referida empresa, contra o produtor independente.

Assim, somente após a reeleição do Governo Thatcher, é que o Reino Unido ${ }^{138}$ pôde experimentar a quebra na hegemonia política do CGEB, através da publicação do 1988 White Paper, que propôs as seguintes medidas:

a) as atividades de geração e transmissão foram separadas, com a extinção da CEGB e a criação de três novas empresas de geração: a National Power - NP -, que ficou com 50\% da capacidade de geração da CEGB, a PowerGen - PG -, que ficou com 30\%, responsáveis pelas centrais termelétricas e hidrelétricas, e a Nuclear Electric, NE -, responsável pelas centrais atômicas e representante de $20 \%$ da capacidade total de geração;

b) a NP e a PG seriam privatizadas, ficando a NE sob responsabilidade do Estado, pela posição estratégica que assumia ${ }^{139}$;

c) os serviços de transmissão de alta voltagem ficariam sob a responsabildiade da National Grid Company - NGC, empresa também criada a partir da extinção da CEGB;

d) as antigas 12 distribuidoras regionais foram transformadas em novas companhias regionais, denominadas $\mathrm{REC}$ 's, e seriam privatizadas;

e) a obrigatoriedade formal de fornecimento de energia elétrica à sociedade foi transferida para as 12 REC's, que assumiriam, também, o controle da NGC; e

\footnotetext{
${ }^{137}$ Sá, E.K. (1995).

${ }^{138}$ A reestruturação da Escócia não será abordada, uma vez que se limitou à privatização das duas empresas anteriormente destacadas mantidas verticalmente integradas. Assim, a reforma inglesa compreende apenas as mudanças ocorridas na Inglaterra e no País de Gales.

${ }^{139}$ Cumpre lembrar, que, originariamente, a NE seria alienada, juntamente com a National Power, porém dadas as suas restrições de caráter político, econômico e ambiental, optou-se por manter sua propriedade estatal.
} 
f) a criação de um órgão regulador, Office of Electricity Regulation (OFFER), responsável pelo controle dos preços dos monopólios na transmissão e distribuição, e pela regulação da indústria, completaria a reforma.

$\mathrm{Na}$ verdade, com essa nova formatação, ganha espaço a figura do agente regulador, que passaria a assumir as seguintes atribuições ${ }^{140}$ : assegurar que a demanda de eletricidade fosse satisfatoriamente atendida, certificar-se do cumprimento das licenças, de maneira a proteger o consumidor e promover a competição na geração e fornecimento de eletricidade. Para o bom resultado desta última atribuição tornam-se necessárias remover à barreira a entrada nestes segmentos, coibir a manipulação e discriminação de preços e identificar outras imperfeições do mercado. Assim, apesar da complexidade dessa indústria, várias medidas regulatórias foram estabelecidas, de maneira a contornar essas imperfeições e coibir práticas abusivas de aumento de preços, em especial nas atividades onde haja monopólio, das quais Rodrigues, A.P. \& Dias, D.S. (1994) destacam:

a) o controle das taxas cobradas pelas REC's e pela NGC, na distribuição e transmissão, de acordo com fórmula pré-estabelecida pelo regulador;

b) a NGC tem como receita a soma de um conjunto de taxas aplicadas aos geradores e às empresas vendedoras de eletricidade - distribuidoras ou geradoras - pelo uso do sistema e conexão à rede;

c) as REC's têm uma fatia cativa da oferta direta de energia - venda e atendimento ao consumidor final -, porém são obrigadas a apresentar contabilidade distinta para as diferentes atividades. Com isso, empresas geradoras e regionais, vindas de outras áreas, poderão ocupar parcela do mercado não reservada;

d) o controle sobre a oferta de energia será diferenciado para pequenos e grandes consumidores. Para grandes consumidores - demanda superior a $1 \mathrm{MW}$ - a oferta de eletricidade não seria regulada, abrindo a possibilidade de negociar livremente seu suprimento (este limite foi reduzido para $100 \mathrm{~kW}$ em abril de 1994. Estava previsto para abril de 1998, a liberdade irrestrita de comercialização de energia. Entretanto este prazo foi extendido para outubro de 1998. Já os consumidores abaixo deste limite de consumo são considerados membros do "mercado cativo", por terem acesso a um único comercializador (no caso, a distribuidora de sua área de concessão);

\footnotetext{
${ }^{140}$ Rodrigues, A. P. \& Dias, D.S. (1994, p. 30).
} 
e) as empresas de geração e de distribuição, que expandirem suas atividades para outras áreas, serão obrigadas a apresentar contabilidade separada par cada etapa de seus negócios, de forma a permitir ao regulador apurar eventuais práticas de subsídios cruzados entre as diversas atividades da empresa;

f) a NP e a PG têm acesso limitado à venda direta de eletricidade, porém as REC's não poderão gerar mais do que $15 \%$ de sua demanda de eletricidade;

g) a NGC não poderá participa da oferta de eletricidade, logo não poderá atuar entre fatia do mercado de energia;

h) o livre aceso de terceiros às linhas de transmissão e distribuição devem ser assegurados, desde que com taxas reguladas; e

i) as REC's devem adquirir uma parcela de sua demanda de energia de fontes que utilizem combustíveis não fósseis - particularmente energia nuclear. Os custos adicionais representados por esse combustível serão compensados por um imposto sobre a venda de combustíveis fósseis.

Completando o modelo, foi adotada a política tarifária centrada do price cap. Assim, de acordo com a fórmula RPI-X, as tarifas não poderiam subir durante um período determinado (no caso cinco anos) mais que o índice geral de preços - Retail Price Index (RPI), descontado um fator de produtividade previamente definido para cada distribuidora, o termo X. A idéia da introdução do fator X seria estimular a empresa regulada a reduzir seus custos, incrementando sua produtividade, de maneira a apropriar-se do ganhos superiores ao fator, até o período estipulado, onde seriam revistas as condições para a fixação de uma nova base.

No caso do segmento de fornecimento de energia, as REC's obedecem a seguinte fórmula:

RPI - X + Y

O termo $\mathrm{Y}$ inclui todos os custos que independem de ações das REC's e que poderão ser repassados para o preço da eletricidade vendida. Com essa formulação, as REC's estão autorizadas a repassar para seus preços até $95 \%$ de todos seus custos ${ }^{141}$, conforme podemos ver pela caracterização explicitada abaixo:

${ }^{141}$ Mackerron (1995). 
a) Custos de geração $=57 \%$ (compra assegurada);

b) Custos de Distribuição $=24 \%$ (regulados pela OFFER);

c) Imposto sobre combustíveis fósseis $=10 \%$ (para avançar a energia nuclear); e

d) Custos da NGC $=4 \%$ (custos de transmissão)

Apesar de toda essa preocupação em repassar ao consumidor eventuais ganhos de produtividade conseguidos pelas empresas, o comportamento do agente regulador tem revelado sua incapacidade para viabilizar essa transferência de renda entre os agentes. Isto porque, tanto na definição do valor do $\mathrm{X}$ inicial, estabelecido como zero para transmissão e chegando a assumir na distribuição, valor negativo para algumas distribuidoras, como na primeira revisão de tal fator, entre 1993/94, os níveis de X estabelecidos e os preços alcançados demonstram que os maiores beneficiários desse modelo têm sido os acionistas, resultados a serem comprovados ao longo do trabalho.

Finalizando, cumpre destacar a importância da introdução do mercado atacadista de energia, na nova estrutura do setor elétrico inglês. A proposta, seguida por diversos países, pregava a formação de um sistema, denominado Pool System, no qual, diariamente, distintos geradores passavam a despachar energia a um agente transmissor, função assumida pela NGC, de forma a garantir um fluxo contínuo de equilíbrio entre oferta e demanda desse produto $^{142}$.

Assim, as centrais geradoras proveriam informações sobre preços e quantidades de energia que se dispunham a ofertar, em atacado, para cada meia hora - 48 vezes ao dia - do dia seguinte. A partir de tais informações, a NGC, usando com suporte a estrutura de despacho técnico de plantas de geração, herdada da antiga CEGB, estabelecia uma ordem de mérito, composta pelos seguintes pontos: preço ofertado para uma certa demanda de energia, localização da usina em relação à rede e flexibilidade da mesma em atender a um crescimento repentino na demanda. Tais critérios orientariam o despacho do dia seguinte, visando otimizar a eficiência do sistema, ou seja, fazê-lo funcionar ao menor custo operacional, desde que garantida a estabilidade e as reservas de capacidade para as horas de pico da demanda.

\footnotetext{
${ }^{142}$ Cumpre lembrar que a NGC, além de coordenar toda a produção de usinas de capacidade superior a 10 MW, gerencia os blocos de energia exportados da Escócia (850 MW) e da França (2.000 MW). Para maiores detalhes ver Rosa, L.P., Tolmasquim, M.T. \& Pires, J.C.L. (1998).
} 
Conforme destaca Sá (1995, p. 137), o que diferencia este sistema do anterior é que a seleção das usinas para operar num determinado dia para a rede é feita pelo preço ofertado de eletricidade pelas geradoras e não pelo custo operacional da usina. Ressalte-se, entretanto, que dois preços seriam fundamentais para a dinâmica desses leilões, a saber ${ }^{143}$ :

a) um preço que a rede pagaria aos geradores por produzirem eletricidade - pool input price (pip) ou pool purchase price (ppp). A fórmula para estabelecer esse preço seria composta por dois elementos: os custos de combustíveis e operacionais de curto prazo e uma parcela que cobriria o investimento em capacidade de geração, expressa na equação abaixo relacionada.

pip $=$ smp $+($ voll - smp $)$ lolp ${ }^{144}$, sendo:

pip = pool input price;

smp = custo marginal de geração;

voll = um valor que refletiria os custos de interrupções de oferta para os consumidores; $e$

lolp = a probabilidade de um choque de demanda superar a capacidade instalada.

b) um preço pelo qual os fornecedores comprariam eletricidade da rede. Esse preço, chamado pool output price ( $p o p$ ) ou pool selling price ( $p s p$ ), seria o preço pip mais um adicional de custos pago aos geradores (uplift).

pop $=$ pip + uplift

Ademais, como ao longo do dia, percebe-se uma forte alteração de preços entre os horários de pico e os de baixa demanda, os agentes do mercado buscam estabelecer, através de contratos com prazos maiores, condições mais firmes de preço, com o objetivo de minimizar os riscos. Através de Contracts for Differences (CFD's), geradores e fornecedores firmam um preço por $\mathrm{kWh}$ (strike price) para um determinado ponto futuro. Como a remuneração dos geradores é definida pelo preço do pool, caso este estivesse acima dos preços dos contratos, os geradores reembolsavam as distribuidoras e vice-versa no caso

\footnotetext{
${ }^{143}$ Rodrigues, A.P. \& Dias, D.S. (1994, p.32).

${ }^{144}$ Evidentemente que, em épocas onde houver geração em excesso, o lolp será pequeno, e haverá pouco incentivo para se investir; ao passo que quando a capacidade de geração for menor, lolp será grande, encorajando os investimentos no setor. Takata, D. (1997, p. 75).
} 
dos preços do pool ficarem abaixo do valor contratado.

$\mathrm{Na}$ prática, estes contratos eliminaram qualquer possibilidade de competição no setor, cabendo ao pool comercializar cerca de $10 \%$ do total de energia gerada na Inglaterra ${ }^{145}$. Esse resultado, também pode ser explicado, em parte, pelas desvantajosas posições obtidas pelos compradores - num mercado dominado pelo duopólio das geradoras National Power e Power Gen.

Como destacado anteriormente, as duas, ao deterem quase $80 \%$ da eletricidade total gerada no país, tinham condições de manipular os preços do pool, ao indisponibilizarem plantas para o despacho técnico geração. Com isso, o valor do componente de capacidade, $L O L P$, expresso na fórmula, era puxado para cima de forma artificial, comprometendo o preço estabelecido no pool. Como esse procedimento, também, passou a fazer parte da estratégia brasileira, a opção de deixá-lo registrado no presente anexo, é oportuna.

Já a caracterização da reforma norueguesa visa descrever uma experiência de liberalização do comércio de energia, em um país com parque gerador muito similar ao caso brasileiro, que obteve uma estrutura competitiva, mantendo, entretanto, o caráter estatal dos ativos.

O Mercado de Energia na Noruega foi desregulamentado, em 1991, mas a privatização não foi colocada, o que torna mais oportuna a avaliação dessa opção de política para o setor. De fato, essa reestruturação industrial, assim como no caso inglês, visou introduzir a concorrência na geração, estabelecendo o livre acesso à rede de transporte, com desverticalização da empresa estatal, mas sem alterar o caráter público dos ativos.

O “Energy Act of June”, publicado em 1990, que serviu de base legal para a reforma, foi baseado na proposta formulada durante a gestão do governo conservador, porém implantada pelo governo trabalhista, que o sucedeu, sem nenhuma mudança de direção. Talvez o grande apoio a essa nova orientação esteja na manutenção da propriedade das empresas nas mãos do Estado. Isto porque, a indústria de energia na Noruega tem sido dominada por agentes públicos (federal, estadual e municipal), em uma estrutura organizacional descentralizada e bastante fragmentada. Essa configuração é resultado tanto das condições geográficas, dada a dispersa e abundante localização de recursos hídricos no

\footnotetext{
${ }^{145}$ Rosa, L.P., Tolmasquim, M.T. \& Pires, J.C.L. (1998).
} 
país, como políticas, tradição de independência das municipalidades norueguesas, acabaram por influenciar a organização industrial interna do setor.

$\mathrm{Na}$ verdade, antes da reforma, a estrutura de mercado dessa indústria, caracterizada em Rosa, Tolmasquim, \& Pires (1998, p. 62-66), apresentava uma expressiva participação do agente federal na atividade de geração e transmissão, sendo a Statkraft a maior delas, detendo quase $30 \%$ da capacidade e supridora direta das indústrias eletro-intensivas, e, eventualmente, das concessionárias distribuidoras. O setor privado era responsável por $15 \%$ da geração, na sua maioria auto-produtor independente. As pequenas companhias municipais e estaduais de distribuição, dentre as quais metade era verticalmente integrada (geração, transmissão e distribuição), respondiam pelo 55\% restante da geração.

O segmento de transporte é composto pelas redes de transmissão e de distribuição, sendo um monopólio único na transmissão em alta tensão (rede de transmissão principal), da qual a Statkraft é a proprietária de $80 \%$. Os restantes $20 \%$ são divididos entre 30 diferentes companhias privadas e arrendadas para a Statkraft. As redes regionais de média voltagem são de propriedade de 54 concessionárias, dentre as quais 40 são também distribuidoras. Existem, ainda, cerca de 30 redes regionais e mais de 200 redes locais, destacando que a maioria dos proprietários das redes locais são os municípios, que distribuem a energia em sua própria área.

Com tal fragmentação e descentralização institucional, o mercado de energia da Noruega revelou-se ineficiente, explicado, pelo menos, por dois aspectos:

a) a maior parte das concessionárias municipais, normalmente, preferiam desenvolver seus próprios aproveitamentos hidrelétricos. Essa postura, além de acarretar uma perda de seqüência ótima de obras, inibia a prática de contratação de potência já disponível, gerando excedente de capacidade instalada e aumento nas sobras de energia; e

b) as concessionárias de distribuição e as empresas regionais de geração formalizavam contratos casados. Dessa maneira, não havia interesse na redução dos custos de suprimento, visto que na maioria dos casos a municipalidade era dona ou sócia da geradora regional. Assim, tais concessionária apenas realizavam uma transferência de recursos inter-empresas e o consumidor cativo da distribuidora acabava pagando 
a conta, com tarifas mais elevadas que o necessário.

Tentando contornar esses problemas, já em 1971, foi criado o Mercado Spot de comercialização ocasional de energia - o Pool Samkjoringen - criado através da fusão de sete pools regionais e operados de forma cooperativa entre as 60 empresas participantes. Com base em leilões de compra e venda (competitive bidding), este mercado tinha a função de fazer intercâmbio das sobras de energia dos diversos aproveitamentos hídricos, visando sua otimização.

Completando os fatores políticos e organizacionais, que impulsionaram a reforma implementada no setor elétrico norueguês, em 1991, cumpre apontar para pelo menos um fator de ordem técnica que, também, contribuiu para tais mudanças ${ }^{146}$.

Deve-se registrar, inicialmente, que, sendo $99 \%$ da energia gerada na Noruega decorrente de base hidrelétrica, sua estrutura de custo revela uma alta parcela de custos fixos com menor nível de custo variável. As oscilações de preços, entretanto, são verificadas muito em função da capacidade de produção e dos reservatórios, com base no comportamento das séries hidrológicas de 50 anos, a exemplo do modelo brasileiro. Assim, em anos de precipitação normal, há uma pequena variação das tarifas relacionadas às estações. Em anos mais secos, verificam-se aumentos das tarifas de energia no inverno e, em anos mais úmidos, preços extremamente baixos no verão.

Dentre os argumentos para o estabelecimento de tais mudanças podem ser destacados os seguintes ${ }^{147}$ :

a) evitar investimentos excessivos, dado que, conforme mencionado nos parágrafos anteriores, muitas das decisões de investimentos são provocados pelo caráter descentralizado do sistema, incentivado pela estrutura tarifária incorrida pelo custo do serviço e repassado aos consumidores;

b) incentivar projetos de investimento mais seletivos, dentro de um plano pelo menor custo;

c) criar incentivo para redução de custos, através de um ambiente competitivo na geração e na comercialização;

\footnotetext{
${ }^{146}$ A descrição de tais aspectos pode ser encontrada em Wangensteeen, I. \& Holtan, J.A. (1995).

${ }^{147}$ Wangensteeen, I. \& Holtan, J.A. (1995) e Rosa, L.P., Tolmasquim, M. T.e Pires, J.C.L (1998).
} 
d) promover a eqüidade entre os consumidores, eliminando os subsídios cruzados, uma vez que tal prática conduz a perda para a sociedade; e

e) eliminar as dispersões geográficas de preços.

Assim, conforme colocado por Rosa, Tolmasquim, \& Pires (1998), "a empresa Statkraft foi dividida em uma de geração - Norwegian Energy Corporation (Statkraft SF) e - uma outra empresa de transmissão - Nowergian Power Grid Co. (Statnet SF). O antigo pool Samkjoringen passou a ser operado por uma empresa governamental, Statnet-Market, uma subsidiária da Statnet, tendo sido criada, também, uma agência de regulamentação Norwegian Water Recourses and Energy Administration (Norges Energiverkforbund) NVE. O restante da estrutura industrial - em suas dimensões municipais e regionais - não foi alterado pela reforma".

Quanto às novas estruturas de mercado, podem-se identificar duas, a saber: mercado de energia no atacado e mercado varejista. O primeiro envolve produtores, empresas de distribuição e alguns dos maiores consumidores industriais. O segundo é voltado para a venda de energia ao consumidor final.

O Mercado Atacadista de Energia pode ser dividido entre os mercados organizados e os contratos bilaterais. No caso dos mercados organizados, Wangensteeen e Holtan (1995) identificaram três tipos físicos de mercado, organizados pelo operador da rede Statnet-Market -, a saber: mercado spot, mercado regulador e mercado semanal ${ }^{148}$. O conjunto destes segmentos respondia por cerca de 33\% do total da produção de energia em 1995, revelando uma evidente tendência de crescimento ${ }^{149}$.

a) Mercado Spot: é estabelecido diariamente às 12:00 para entrega de energia no dia seguinte. Noventa participantes submetem suas propostas para compra e venda de energia, para cada 8 intervalos definidos por dia. Tais propostas são na verdade curvas de oferta e demanda individuais, que são agregadas pelo Statnet, como operador do mercado, para formar as curvas totais de oferta e demanda. No local onde as curvas se interceptam são definidos os preços e as quantidades de energia. A partir dessa definição, os participantes expressam quanto eles estão dispostos a vender ou comprar em cada intervalo e a que preço. Cerca de 10 a $15 \%$ da energia

\footnotetext{
${ }^{148}$ Para qualificar estes três tipos de mercado, será utilizado o texto de Takata, D. (1997, pp. 61-63).

${ }^{149}$ Rosa, L.P., Tolmasquim, M. T.e Pires, J.C.L (1998, p. 70).
} 
gerada é negociada no mercado spot e o preço deste mercado serve para balizar o preço dos contratos de longo prazo.

b) Mercador Regulador: utilizado para adaptar a produção às variações de carga. A princípio, todos os geradores e consumidores deveriam participar desde que obedeçam ao requisito de ajustar suas gerações ou demandas, dentro de um período de 15 minutos. Na prática, entretanto, somente produtores participam desse mercado. Toda noite, os produtores informam ao Statnet quanto eles estariam dispostos a variar da geração, para cima ou para baixo, a que preço e por quanto tempo. Em uma operação de tempo real, a Statnet, então, considera o regulador mais barato de sua lista de preços. A tarifa de energia no mercado regulador é estabelecida ex post, quando a tarifa do regulador marginal, em cada hora do dia, for conhecida. Todos os reguladores recebem a tarifa do regulador marginal.

c) Mercado Semanal: é um mercado para entrega futura, sendo os contratos de dois tipos: o de Energia Básica (Base Load), representado pela demanda constante para 168 horas da semana e o de Energia Diária (Day Load), representada pela demanda constante para as 75 horas semanais (de segunda a sexta-feira, das 7 às 22 horas).

Além dessas três modalidades, o governo permite que se mantenham os contratos bilaterais, que podem ser renegociados entre as partes. Tais operações continuam sendo as predominantes no mercado norueguês (cerca de $77 \%$ do mercado) ${ }^{150}$.

O Comércio Varejista de Energia, por outro lado, foi introduzido para proporcionar aos usuários finais a opção de escolher suas condições de suprimento. Neste sentido, a regulação é mínima neste mercado, uma vez que os supridores e os distribuidores poderão negociar as melhores condições contratuais, estimulando o aparecimento de novos agentes neste segmento do mercado, tais como os comercializadores e corretores de energia.

Além disso, a reforma norueguesa introduziu o livre acesso a todas as redes, incluindo as locais e as regionais, acompanhado do estabelecimento de tarifas de transporte não discriminatórias. Esse livre acesso, entretanto, ao contrário do caso inglês, não implicou a desverticalização total e completa das empresas, mas são impedidas de usar mecanismos de subsídios cruzados. São obrigadas, ainda, de contabilizar, em separado,

\footnotetext{
${ }^{150}$ Rosa, L.P., Tolmasquim, M. T.e Pires, J.C.L (1998, p. 72).
} 
suas estruturas de custo nas atividades de transmissão/distribuição, cujas tarifas de transporte são definidas e controladas pelo NVE.

Com estas medidas, conforme ressalta Rosa, Tolmasquim, \& Pires (1998), "os distribuidores perderam o direito exclusivo de fornecimento em sua área de concessão, passando a estar sujeitos à competição de outros distribuidores ou mesmo comercializadores".

Ademais, como a administração do grid passou a ser exercida pela Statnet, suas principais funções podem ser resumidas, como bem apontam os autores, em:

a) operar a malha principal de transmissão, incluindo as conexões com os outros países;

b) proporcionar os serviços de transporte de energia na malha principal, cobrando para isso uma tarifa de uniforme;

c) coordenar a geração, com a preocupação de manter um nível aceitável de confiabilidade em todos os níveis do sistema de transmissão;

d) proporcionar as trocas de potência, de maneira a ajudar a comercialização das potências de curto e longo prazos;

e) coordenar as importações e exportações de outros países nórdicos ; e

f) planejar a expansão e a manutenção do sistema de transmissão em cooperação com os usuários do grid.

Finalmente, devem-se registrar as funções a serem exercidas pelo agente regulador da Noruega, ou seja, o NVE. Esse tem a responsabilidade de regular às partes monopolizadas, supervisionando os segmentos sujeitos à concorrência, com o objetivo de promover a eficiência econômica em todos os setores da indústria.

Quanto à reforma argentina, por ser marcada tanto pela rápida implantação, imposta, basicamente, em decorrência de suas restrições macroeconômicas, quanto por uma alta concentração pós-reforma, resultado da ausência de um marco regulatório adequado para o setor, pode contribuir para ilustrar as semelhanças verificadas pelo modelo brasileiro. Isto porque, a história da formação da indústria de suprimento de energia na 
Argentina é bastante similar à brasileira, ou seja, inicia-se com capitais estrangeiros, desenvolvendo-se, no pós-guerra, através de empresas estatais.

Por ocasião da crise do petróleo, durante a década de 70 , conforme destacado por Rosa, Tolmasquim, e Pires (1998), o governo argentino passou a estimular a diversificação energética, através da construção de centrais hidrelétricas e nucleares. Tais empreendimentos, ao serem realizados por novos atores (cooperativas, geradoras estaduais, empresas federais com participação minoritária privada, etc.), acabaram por trazer reflexos para a organização industrial deste setor. Como resultado, a Aguas y Energia Eléctrica (AYE) e a SEGBA, concessionária federal de distribuição da Grande Buenos Aires, tiveram uma redução substancial no total da capacidade instalada: de 80\% (1970) para 59\% (1980).

Além disso, embora ao final da década de 80 , mais de $84 \%$ da população Argentina tivesse acesso à rede elétrica, a desorganização social e política provocada pelo período da ditadura militar e pelos diversos pacotes de estabilização, levaram o setor a uma crise de oferta de eletricidade, caracterizada, inclusive, por uma complexa estrutura institucional, com uma multiplicidade de agentes federais, provinciais e cooperativas, estando ${ }^{151}$ :

a) a Comissão Nacional de Energia Nuclear (CNEA), responsável pela operação das usinas nucleares, diretamente subordinada à Presidência da República;

b) a Comissão Técnica Mista Salto Grande (CTMSG), responsável pela operação da central binacional de Salto Grande (com o Uruguai), subordinada ao Ministério das Relações Exteriores;

c) as empresas federais de geração hidrelétrica (Hidronor e AYE) e a SEGBA, sob controle do Ministério de Obras Públicas;

d) as empresas provinciais sob controle provincial; e

e) um grande número de cooperativas responsabilizava-se, principalmente, pelo abastecimento das zonas rurais.

Neste contexto e em amplo período de eleições presidenciais, o setor enfrentava uma grave crise de abastecimento. Com a vitória de Menem, representante absoluto da orientação de política neoliberal, deu-se início ao processo de reestruturação e privatização do setor elétrico argentino.

\footnotetext{
${ }^{151} \operatorname{IPEA}(1997$, p. 131).
} 
Centrado no argumento de que a crise fiscal do Estado Argentino teria comprometido a capacidade de investimentos no setor, afetando sobremaneira a qualidade dos serviços prestados e elevando os níveis de perdas técnicas e não técnicas do sistema, o governo central defendeu um rápido processo de reestruturação setorial, fragmentando as empresas federais em várias unidades de negócio.

Com isso, o governo federal pretendia, de um lado, garantir a entrada de recursos fiscais no curto prazo e, de outro, evitar a transferência do monopólio estatal para o setor privado, conforme verificado no caso inglês. A política de privatização das empresas federais foi seguida pelas províncias, que, também, passaram a adotar o mesmo procedimento.

Ao final do processo, as três empresas federais argentinas deram origem a três empresas de distribuição, seis empresas de transmissão e 21 empresas de geração, convivendo com 21 empresas de distribuição de propriedade das províncias (com regulação específica) e seiscentas minicooperativas municipais ${ }^{152}$, lembrando que o volume de recursos arrecadados somente com as privatizações do setor elétrico federal foi da ordem de US\$2,663 bilhões.

De forma a completar as informações relativas à mudança do setor elétrico argentino merece destaque a criação do Mercado Electrico Mayorista (MEM) e da Cammesa (Compañia Administradora del Mercado Mayorista Electrico Sociedad Anônima).

Ao exemplo do modelo adotado na Inglaterra, o MEM foi instalado com o objetivo de introduzir um ambiente competitivo de energia elétrica, com a participação dos geradores, dos distribuidores e dos grandes consumidores (acima de 1 Mwh de consumo mensal). O MEM é administrado pela Cammesa, companhia independente, da qual participam com $20 \%$ das ações, respectivamente as associações dos geradores, distribuidores, transmissores ${ }^{153}$ e grandes consumidores; o governo, inicialmente, detinha os outros 20\%, tendo reduzido sua parcela a 10\%, em 1998 .

A Secretaria de Energia, entretanto, possui poder de veto nas decisões da Cammesa,

\footnotetext{
${ }^{152}$ Rosa, L.P., Tolmasquim, M.T. \& Pires, J.C.L. (1998, p. 138).

${ }^{153}$ Ressalte-se que as empresas de transmissão ficaram com a tarefa de apenas transportar a energia, tendo sido aberta a rede a geradores, distribuidores e grandes consumidores, mediante o pagamento de um pedágio, definido pelo regulador.
} 
cujas responsabilidades centram-se em organizar o despacho econômico de carga, administrando dois mercados caracterizados por modalidades de transação diferentes, a saber: o de contratos de longo prazo e o de curto prazo (spot).

O primeiro concentra a maior parte da energia gerada (cerca de $95 \%$ do total) e tem uma periodicidade mínima anual. O segundo representa, basicamente, um mercado de sobras. Nele, cada gerador é remunerado em função do custo marginal de curtíssimo prazo, através de leilões horários. Assim, a cada hora do dia, é despachada a unidade geradora, geralmente térmica, que oferece o menor custo marginal de consumo de combustível. Segundo Rosa, Tolmasquim, \& Pires (1998, p. 140), “a valoração desse consumo, ao preço do combustível vigente, dá o preço marginal de energia, pago a todos os geradores, por toda a energia que vendem, exceto a energia já contratada".

Por fim, vale a pena mencionar a criação do ente regulador, que no caso da Argentina, é representado por um órgão de jurisdição federal, com perfil independente (membros são nomeados pelo Congresso Nacional e têm mandato fixo) - denominado Ente Nacional Regulador de la Electricid (ENRE). Dentre suas principais atribuições destacamse as seguintes:

a) definir os valores tarifários para o mercado cativo de energia elétrica (consumidores com demanda inferior a $1 \mathrm{MWh}$ anual);

b) estabelecer o pedágio par o setor de transmissão;

c) impedir a concentração do mercado (não pode haver cruzamento acionário entre os segmentos de geração, transmissão e distribuição; e

d) estimular o fim de preços ineficientes (fim dos subsídios para consumidores).

Em suma, com este conjunto de informações relativas às características que marcaram as mudanças do setor elétrico nos países selecionados, pretendeu-se, de um lado, registrar algumas das principais particularidades dos modelos de reestruturação estudados, e de outro, reforçar, através de algumas ilustrações específicas, a tese central do presente trabalho de que existe uma forte relação entre as opções conduzidas e os principais resultados esperados com tais reformas, na expectativa de que os erros e avanços de cada uma delas possam ser aproveitados em estudos futuros. 